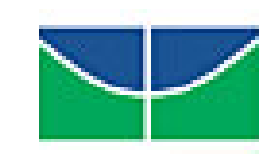

Universidade de Brasília

Faculdade de Ciência da Informação

Programa de Pós-Graduação em Ciência da Informação

\title{
Segurança contra roubo e furto de livros raros: uma perspectiva sob a ótica da Economia do Crime e da Teoria da Dissuasão
}

\author{
Volume 1 \\ Raphael Diego Greenhalgh
}

Orientadora:

Profa. Dra. Miriam Paula Manini

Brasília-DF 


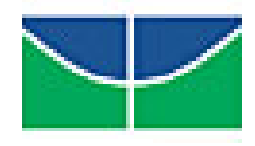

Universidade de Brasília

Faculdade de Ciência da Informação

Programa de Pós-Graduação em Ciência da Informação

\section{Segurança contra roubo e furto de livros raros: uma perspectiva sob a ótica da Economia do Crime e da Teoria da Dissuasão}

Tese de Doutorado apresentada ao Programa de PósGraduação em Ciência da Informação, da Faculdade de Ciência da Informação da Universidade de Brasília, como requisito parcial à obtenção do título de Doutor em Ciência da Informação.

Orientadora: Profa. Dra. Miriam Paula Manini 
G813s Greenhalgh, Raphael Diego

Segurança contra roubo e furto de livros raros: uma perspectiva sob a ótica da Economia do Crime e da Teoria da Dissuasão / Raphael Diego Greenhalgh. - 2014.

2 v. : il., color.

Tese (Doutorado em Ciência da Informação) - Universidade de Brasília

Orientação: Profa. Dra. Miriam Paula Manini

1. Biblioteconomia de Livros Raros. 2. Obras Raras. 3. Segurança contra roubo e furto. 4. Roubo e furto de Livros Raros. 5. Economia do Crime. 6. Teoria da Dissuasão. I. Título.

CDU 094:343.71 


\section{FOLHA DE APROVAÇÃO}

Título: "Segurança contra roubo e furto de livros raros: uma perspectiva sob a ótica da Economia do Crime e da Teoria da Dissuasão".

\section{Autor (a): Raphael Diego Greenhalgh}

Área de concentração: Gestão da Informação

Linha de pesquisa: Organização da Informação

Tese submetida à Comissão Examinadora designada pelo Colegiado do Programa de Pósgraduação em Ciência da Informação da Faculdade em Ciência da Informação da Universidade de Brasília como requisito parcial para obtenção do título de Doutor em Ciência da Informação.

Tese aprovada em: 25 de novembro de 2014 .

Profa. Dra. Miriam Paula Manini

Presidente (UnB/PPGCINF)

Profa. Dra. Dulce Maria Baptista

Membro Interno (UnB/PPGCINF)

Prof ${ }^{a}$. Dra . Lillian Maria Araújo de Rezende Alvares Membro Interno (UnB/PPGCINF)

Profa. Dra. Adriana Lúcia Cox Hollós

Membro Externo (Arquivo Nacional)

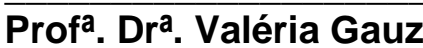

Membro Externo (Museu da República)

Prof ${ }^{\mathrm{a}}$. Dra. Eliane Braga de Oliveira

Suplente (UnB/PPGCINF) 


\section{Dedicatória}

Dedico à minha mãezinha querida, à minha vovó Maria, essas duas que eu amo tanto, mulheres da minha vida. Ao meu avô João, que infelizmente nos deixou há pouco. Agradecendo também estes para além do óbvio, por todo amor e carinho dado, mas também, por todo o conhecimento compartilhado, daqueles que não se aprende e apreende nos bancos da universidade. Assim como também dedico àqueles que fizeram e fazem parte presente e permanente da minha criação: Tia Regina, Tia Rejane e Padrinho Carlos.

Dedico à minha esposa mais que amada, Mariana, que faz parte indissociável desta trajetória acadêmica e também da minha felicidade e das minhas conquistas, me ajudando a maximizar os momentos felizes e a superar os difíceis.

Dedico também àqueles que me ajudam diariamente simplesmente por me concederem o prazer de participar da vida deles e eles da minha, refletindo diretamente na pessoa que eu sou, como todos os tios e primos, mas, especialmente, aos meus afilhados Fernandinha, João Felipe e João Pedro; aos meus primos Geovany, Cibely e Loyanne. Aos meus amigos de infância GG, Murilo, Kaique, Tetel, Leitão, Rafael Vaz e Marcus Vinícius. Aos amigos Illy, Diego e Seânio, que não são de infância, mas é como se fossem, pois estão entre os melhores.

Dedico aos meus tios Bernardo e Omilda, que foram fundamentais em meus estudos e profissão, me acolhendo em sua casa, com paciência e carinho, tratando-me como um filho. 


\section{Agradecimentos}

Agradeço ao Murilo, amigo de infância, pelas preciosas dicas em Direito, que muito me ajudaram na análise dos dados e dos processos judiciais.

Agradeço à minha esposa Mariana pelas inúmeras leituras e comentários sobre o texto e o desenvolvimento do trabalho, que me ajudaram a melhorá-lo.

Agradeço a todos os meus colegas de trabalho, que se tornaram amigos e me acrescentaram enquanto pessoa e me ajudaram no engrandecimento profissional, em especial à Josilene, ao Nilton, ao Daniel e ao Bruno. Assim como aos meus queridos colegas da Biblioteca Central (BCE) da UnB, que agradeço na figura de: Fernando, Neide, Néria, Ilmara, Tânia Milca, Michelle, Marcelo e Francisco Rafael (Chico), alguns destes que influenciaram diretamente para que eu viesse a trabalhar na Coleção de Obras Raras, local que inspirou todo este trabalho.

Agradeço a todos os professores escolares e universitários que são parte de mim e que me inspiraram a seguir os seus passos, os quais reverencio na figura máxima da minha querida orientadora, Prof.a Miriam, a quem é impossível agradecer com palavras por todo o carinho, ensino e confiança.

Agradeço aos membros da banca pelos apontamentos precisos na qualificação, que me ajudaram a melhorar este trabalho. Todos participantes efetivos nesta trajetória, Prof.a Lillian, minha orientadora de monografia de graduação; Prof.a Dulce, que me ajudou com o pré-projeto de mestrado; e Prof.a Valéria, que organizou o folheto, que juntamente com a Coleção de Obras Raras da BCE, me inspirou a fazer este trabalho e Prof.a Adriana que aceitou prontamente participar da banca.

Agradeço ao meu cunhado Ricardo Lúcio de Almeida Ataídes, que se desdobrou, em Curitiba, para conseguir me enviar cópia do processo criminal localizado no Tribunal de Justiça do Estado do Paraná.

Agradeço imensamente a todos aqueles que contribuíram sendo parte deste trabalho, como os respondentes do primeiro questionário e também àqueles que precisaram responder o segundo questionário, cujo nome infelizmente não posso citar, para não expor a segurança de suas instituições. Aos juízes e funcionários da Justiça Federal do Rio de Janeiro, que me 
autorizaram acesso aos processos criminais e que me receberam de forma tão simpática. Ao Prof. Afrânio Vieira pelos conselhos em Estatística. À Denise Christina de Rezende Nicolaidis, Secretária Executiva da 4⿳亠丷厂 Câmara de Coordenação e Revisão - Meio Ambiente e Patrimônio Cultural da Procuradoria Geral da República do Ministério Público Federal, e Romina Capparelli, também funcionária desta instituição, que me receberam tão bem e me foram tão úteis na pesquisa. À Vivian, do Museu Raymundo Ottoni de Castro Maya; Andréa Abraham de Assis, do Museu Emílio Goeldi; Edson Vargas da Silva, do Museu Nacional; Rosana Simões Medeiros, do Instituto de Pesquisas Jardim Botânico, do Rio de Janeiro; Dilza Ramos Bastos, da Casa de Rui Barbosa; Karin Beatriz Pereira de Sousa, da Procuradoria Federal da Fundação Oswaldo Cruz; Jeorgina Gentil Rodrigues e Maria Cláudia Santiago, também da Fundação Oswaldo Cruz; Regina Lúcia Gonçalves e Ludvig Berzin Neto, ambos da $3^{a}$ Delegacia do Patrimônio do Departamento Estadual de Investigações Criminais (Deic) da Polícia Civil do Estado de São Paulo. Aos entrevistados que engrandeceram o trabalho compartilhando seu conhecimento. 
Pois os livros não são, absolutamente, meros objetos inanimados, mas contêm, sim, em si mesmos, uma vida em potencial, que é tão ativa quanto aquela que anima a criatura de quem eles são a progênie; e não apenas isso, mas eles ainda preservam, como se em um frasco, a mais pura eficiência extraída daquele intelecto vivo que os engendrou. 


\section{Resumo}

Os Livros Raros atraem a cobiça de colecionadores, livreiros e quadrilhas especializadas, pelo conteúdo informacional que contêm, seja textual ou visual. Esses visam a lucrar e a obter os poucos - ou únicos - exemplares existentes de uma obra. Vários casos de roubos e furtos de bens culturais e de Livros Raros acontecem no mundo e no Brasil, tornando a perda patrimonial e cultural irreparável. A Economia do Crime mostra que, nas atividades ilegais que envolvem ganho econômico, o criminoso age racionalmente levando em consideração uma relação de custo $\mathrm{X}$ benefício. $\mathrm{O}$ ganho dos criminosos é alto, quando analisados os leilóes de Livros Raros, pois vários exemplares atingem milhões de dólares. Entretanto, quanto maior a percepção do criminoso sobre as possibilidades de punição pela ação ilegal, maiores serão os custos envolvidos, como mostra a Teoria da Dissuasão. O presente trabalho tem como objetivo geral investigar o roubo ou furto de Livros Raros pela perspectiva da Teoria da Dissuasão no contexto da Economia do Crime. Foi realizada uma pesquisa exploratória e descritiva com análise qualiquantitativa da legislação que envolve o livro raro, do rigor penal das condenações dos ladrões deste tipo de obra, do índice de prisão destes criminosos, do índice de recuperação dos itens roubados e de todo o sistema de segurança contra roubo e furto das instituições guardiãs deste tipo de acervo. Foram realizadas entrevistas com especialistas em segurança e gestão de Livros Raros, com um Delegado da Polícia Federal e com funcionários do IPHAN. Também foi enviado questionário às instituições guardiãs de Livros Raros para levantamento das medidas de segurança adotadas contra roubo e furto. Assim como foi enviado questionário às instituições que possuem casos de roubo ou furto deste tipo de acervo. Foram também analisados processos criminais em que havia sido roubado ou furtado ao menos um livro raro. Verificou-se que as instituições não estão seguras contra roubo e furto, pois não adotam sequer metade das ferramentas de segurança questionadas. A segurança deve ser aumentada nestas instituições, pois foi possível averiguar a participação de uma quadrilha especializada em roubo e furto de Livros Raros. Não foram recuperadas nem metade das obras levadas. Apesar de alguns integrantes da quadrilha terem sido condenados e presos, os crimes continuaram a acontecer. Portanto, a prisão e condenação, como também a segurança adotada nas instituições, não estão sendo suficientes para dissuadir os criminosos que roubam e furtam Livros Raros.

Palavras-chave: Biblioteconomia de Livros Raros. Obras Raras. Segurança contra roubo e furto. Roubo e furto de Livros Raros. Economia do Crime. Teoria da Dissuasão. 


\begin{abstract}
Rare books attract the greed of collectors, booksellers and specialty gangs, due to their informational contents, either textual or visual. These aim to profit and get the few - or unique - existing copies of a work. Several cases of robbery and theft of cultural objects and rare books happen in the world and in Brazil, making the irreparable loss of cultural heritage. The Economics of Crime shows that with the illegal activities involving economic gain, the criminal acts rationally considering a cost-benefit relationship. The gain of criminals is high as analyzed in auctions of rare books, because several copies reach millions of dollars. However, the greater the perception about the possibilities of criminal punishment for illegal action, the greater are the costs involved, as shown in Theory for Dissuasion. The present work has as general objective to investigate the theft or robbery of rare books from the perspective of Theory of Dissuasion in the context of Criminal Economy. It was realized an exploratory and descriptive study with qualitative and quantitative analysis of legislation involving rare book, the rigor of penal sentences of thieves of rare books, index of prison for these criminals, the recovery index of stolen works, and the whole system of security against robbery and theft of guardian institutions of this type of collection. Interviews were performed with experts in the security and management of rare books, with a commissary of the Federal Police and with officials from IPHAN. Questionnaire was also sent to the custodian institutions of rare books to survey of the security measures taken against robbery and theft. A questionnaire was sent of to the institutions that have cases of robbery or theft of this type collection. Were also analyzed criminal cases that had been robbed or stolen at least one rare book. It was observed that the institutions are not safe against robbery and theft, because do not even adopt half of the questioned security tools. The security must be increased in these institutions, because it was possible to ascertain the participation of a specialized gang in robbery and theft of rare books. Were not recovered even half of the works taken. Although some members of the gang have been convicted and imprisoned., the crimes continued happening. Therefore, the prision and condemnation, as well the security adopted in institutions have not been enough to deter criminals who rob and steal rare books.
\end{abstract}

Keywords: Librarianship of rare books. Rare books. Security against robbery and theft. Robbery and theft of rare books. Criminal economy. Deterrence Theory. 


\section{Lista de Gráficos e Figuras}

\section{Gráficos}

Gráfico 1 - Dispersão de crimes por ano e estado.

\section{Figuras}

Figura 1 - Encadernação com cantoneiras e broche............................................ 31

Figura 2 - Encadernação bizantina.............................................................. 32

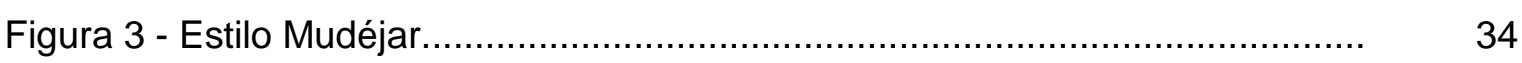

Figura 4 - Estilo Grolier........................................................................ $\quad 34$

Figura 5 - Estilo Thomas Maioli.................................................................. $\quad 35$

Figura 6 - Estilo La Fanfare....................................................................... 36

Figura 7 - Estilo Du Seiul.............................................................................

Figura 8 - Estilo Le Gascon...................................................................... 36

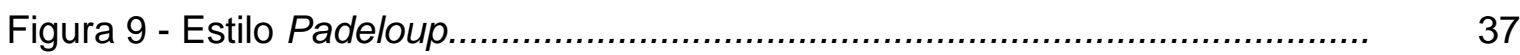

Figura 10 - Encadernação Oriental................................................................ 37

Figura 11 - Encadernação Imperial............................................................. 38

Figura 12 - Encadernação Modernista......................................................... 39

Figura 13 - Ex libris de Igler................................................................... 40

Figura 14 - Ex libris de Hildebrando de Brandenburgo....................................... 41

Figura 15 - Ex libris de Barão do Rio Branco...................................................... 42

Figura 16 - Ex libris de Pedro Nava.................................................................... 43

Figura 17 - Ex libris de Francisco do Assis Carvalho Franco................................. 43

Figura 18 - Ex libris de Th. Alexander................................................................. 44

Figura 19 - Ex libris de Francisco Marques dos Santos...................................... 44

Figura 20 - Censored book............................................. 49

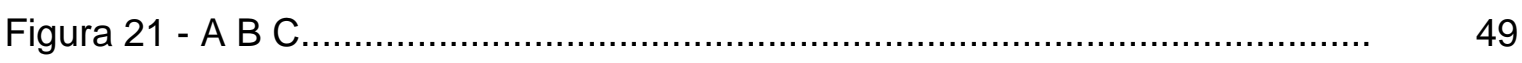

Figura 22 - Fore-edge book.............................................................. 50

Figura 23 - Gravura de Darel (Cem Bibliófilos do Brasil)................................... 51

Figura 24 - Folha de Rosto............................................................................ 84

Figura 25 - Processo de gestão................................................................. 88

Figura 26 - Níveis envoltórios...................................................................... 89

Figura 27 - Modelo de referência OAIS ........................................................... 101

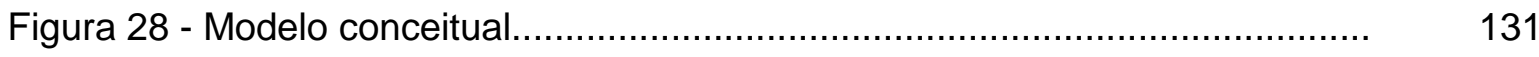

Figura 29 - Dispersão de casos por estado..................................................... 193 


\section{Lista de Quadros e Tabelas}

\section{Quadros}

Quadro 1 - Aspectos a serem observados no colacionamento do livro raro......... 86

Quadro 2 - Penalidades para roubo, furto e crimes relacionados....................... 116

Quadro 3 - Relação entre as diversas Teorias do Crime.................................... 121

Quadro 4 - Comparativo entre as escolas de estudo sobre o crime..................... 122

Quadro 5 - Desenho da pesquisa............................................................. 134

Quadro 6 - Comparativo entre os crimes......................................................... 195

Quadro 7 - Três fases da dosimetria da pena dos processos analisados............. 210

Quadro 8 - Penas aplicadas nas três sentenças............................................. 211

\section{Tabelas}

Tabela 1 - Quantidade de funcionários nas instituições respondentes................. 143

Tabela 2 - Espaços de circulação de usuários................................................. 144

Tabela 3 - Quantidade de opções assinaladas na questão sobre espaços de circulação de usuários................................................................................. 145

Tabela 4 - Horário de funcionamento das Coleções de Livros Raros.................... 147

Tabela 5 - Quantidade de funcionários nas Coleções de Livros Raros................. 147

Tabela 6 - Quantidade de exemplares nas Coleções de Livros Raros.................. 148

Tabela 7 - Reforços nas portas.............................................................. 150

Tabela 8 - Quantidade de respostas positivas nas questões sobre segurança

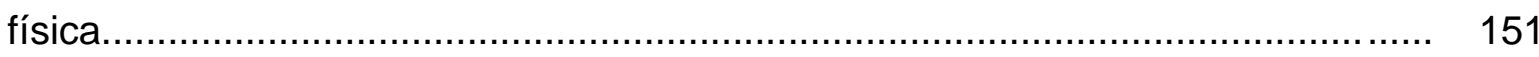

Tabela 9 - Uso de equipamentos eletrônicos................................................... 152

Tabela 10 - Uso das câmeras de segurança.................................................... 153

Tabela 11 - Quantidade de respostas positivas nas questões sobre segurança eletrônica......................................................................................... 154

Tabela 12 - Controle de chaves............................................................... 155

Tabela 13 - Quantidade de opções marcadas na questão sobre métodos de

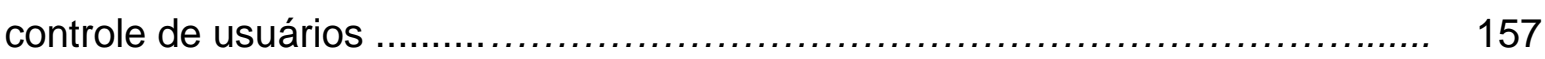

Tabela 14 - Métodos de controle de usuários............................................... 158

Tabela 15 - Marcas de propriedade .......................................................... 161

Tabela 16 - Formação do responsável pela Coleção de Livros Raros................... 164 


\section{Lista de Siglas e Abreviaturas}

ABNT - Associação Brasileira de Normas Técnicas

ACADEPOL - Academia de Polícia

ACRL - Association of College \& Research Libraries

AGCRJ - Arquivo Geral da Cidade do Rio de Janeiro

ALA - Americam Library Association

BCE - Biblioteca Central

BCP - Banco de Dados de Bens Culturais Procurados

BN - Biblioteca Nacional

BNDES - Banco Nacional do Desenvolvimento Econômico e Social

BNF - Biblioteca Nacional da França

BPP - Biblioteca Pública do Paraná

CCJC- Comissão de Constituição e Justiça e de Cidadania

CCLA - Centro de Ciências, Letras e Artes de Campinas

CEM - Centro de Estudos Maristas

CEMI - Centro de Estudos de Migrações Internacionais

CGPN - Coordenador Geral de Patrimônio Natural

Cl - Ciência da Informação

CNART - Cadastro Nacional dos Negociantes de Antiguidades e Obras de Arte

CONARQ - Conselho Nacional de Arquivos

COPE - Centro de Operações Policiais Especiais

CP - Código Penal

CPF - Cadastro de Pessoa Física

DP - Departamento de Polícia

DEIC - Delegacia Estadual de Investigação Criminal

DELEMAPH - Delegacia do Meio Ambiente e Patrimônio Histórico

EBA - Escola de Belas Artes

ENAR - Encontro Nacional de Acervo Raro

FAE - Faculdade Católica de Administração e Economia

FAPESP - Fundação de Amparo à Pesquisa do Estado de São Paulo

FCJA - Fundação Casa de José Américo

FIOCRUZ - Fundação Oswaldo Cruz

IASCJ - Instituto das Apóstolas do Sagrado Coração de Jesus

IBPC - Instituto Brasileiro de Patrimônio Cultural 
IBRAM - Instituto Brasileiro de Museus

IES - Instituição de Ensino Superior

IFLA - International Federation of Library Associations and Institutions

IGHB - Instituto Geográfico e Histórico da Bahia

IPHAN - Instituto do Patrimônio Histórico e Artístico Nacional

IPL - Inquérito Policial

ISO - International Organization for Standardization

LC - Library of Congress

LSO - Library Security Officer

MASP - Museu de Arte de São Paulo

MEC - Ministério da Educação

MINC - Ministério da Cultura

MHN - Museu Histórico Nacional

MPEG - Museu Paraense Emílio Goeldi

MPF - Ministério Público Federal

MR - Magnitude de Risco

NOBRADE - Norma Brasileira de Descrição Arquivística

OAIS - Open Archival Information System

PF - Polícia Federal

PLANOR - Plano Nacional de Recuperação de Obras Raras

PM - Policial Militar

PPGARQ - Programa em Pós-Graduação em Gestão de Documentos e Arquivos

PUC - Pontifícia Universidade Católica

RBMS - Rare Books and Manuscripts Section

RG - Registro Geral

SICG - Sistema Integrado de Conhecimento e Gestão

SNBU - Seminário Nacional de Bibliotecas Universitárias

STJ - Superior Tribunal de Justiça

TRF2 - Tribunal Regional Federal da 2 ${ }^{\underline{a}}$ Região

UBEE - União Brasileira de Educação e Ensino

UEPB - Universidade Estadual da Paraíba

UERJ - Universidade do Estado do Rio de Janeiro

UFBA - Universidade Federal da Bahia

UFF - Universidade Federal Fluminense

UFG - Universidade Federal de Goiás 
UFJF - Universidade Federal de Juiz de Fora

UFOP - Universidade Federal de Ouro Preto

UFRGS - Universidade Federal do Rio Grande do Sul

UFRJ - Universidade Federal do Rio de Janeiro

UnB - Universidade de Brasília

UNESP - Universidade Estadual Paulista

UNICAMP - Universidade Estadual de Campinas

UNIJUI - Universidade de ljuí

UNIRIO - Universidade Federal do Estado do Rio de Janeiro

UNISINOS - Universidade do Vale do Rio dos Sinos

USF - Universidade São Francisco

USP - Universidade de São Paulo 


\section{Sumário}

\section{Volume 1}

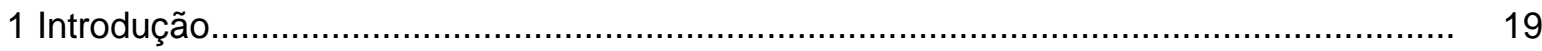

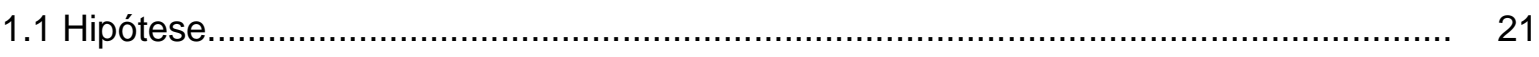

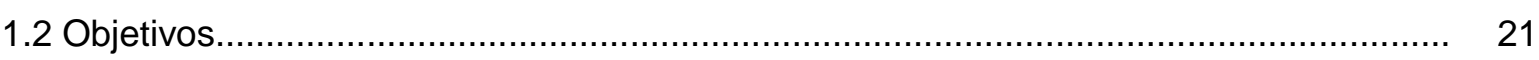

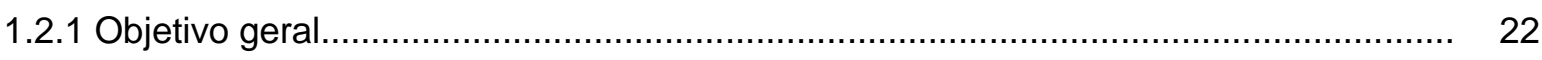

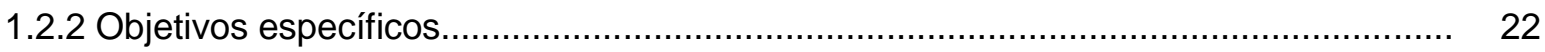

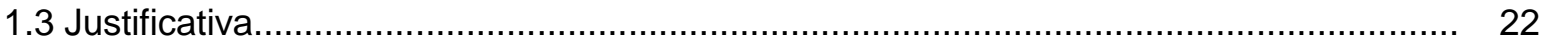

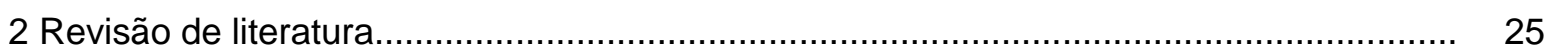

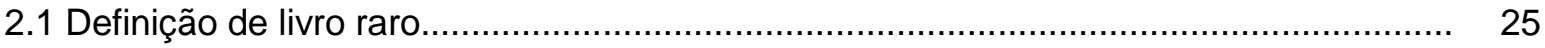

2.1.1 O livro como objeto estético ......................................................................... 29

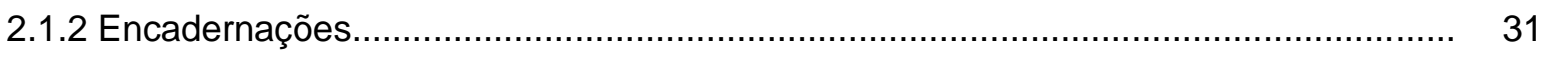

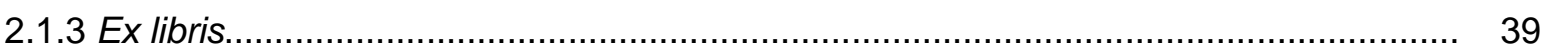

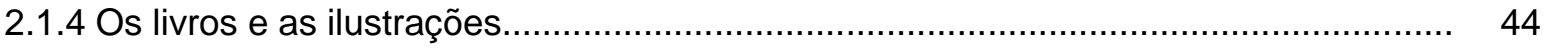

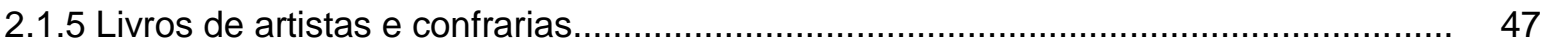

$2.2 \mathrm{O}$ estudo da segurança contra roubo e furto de livros raros na Ciência da Informação.. 52

2.3 Livros raros e memória........................................................................................ 55

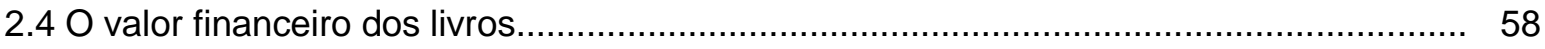



2.5.1 Roubos e furtos de bens culturais no Brasil......................................................... 66

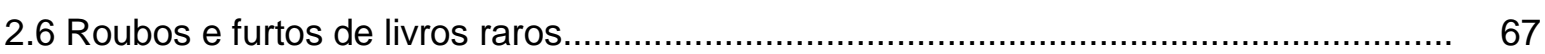

2.6.1 Roubos e furtos de livros raros no Brasil.............................................................. 74

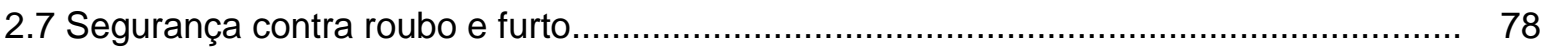



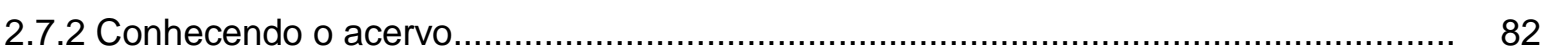

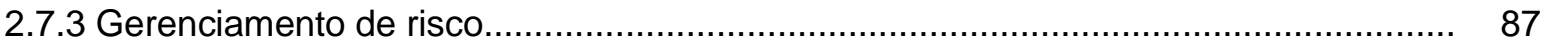

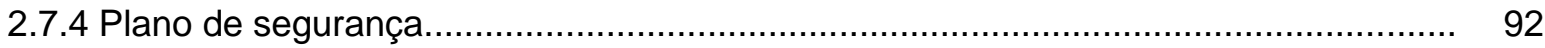

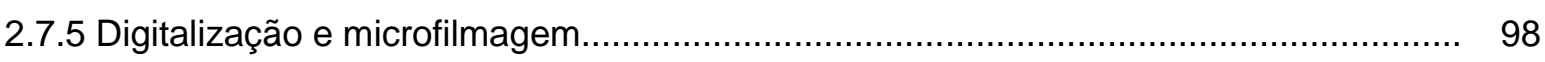

2.7.6 Plano de emergência............................................................................................ 103

2.7.7 Perfil do profissional que cuida de livros raros....................................................... 106

2.8 Legislação de proteção aos livros raros.................................................................... 107

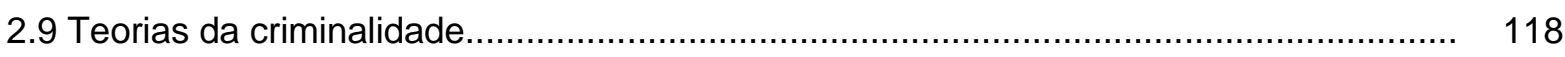



2.9.2 Teoria da Dissuasão................................................................................... 124 
2.9.3 Economia do Crime, Teoria da Dissuasão e livros raros.......................................... 126



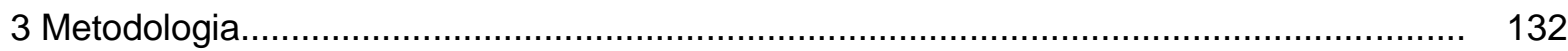

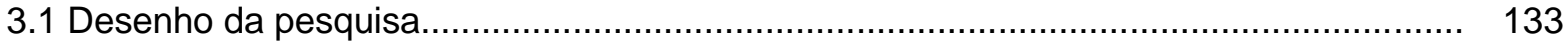

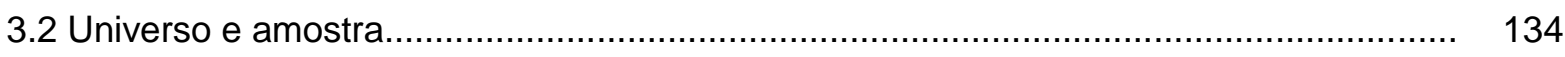

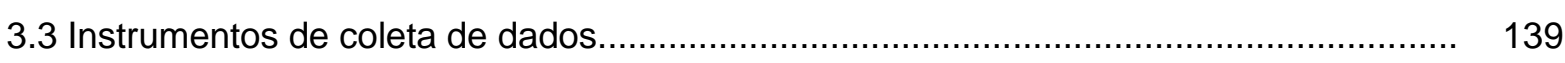



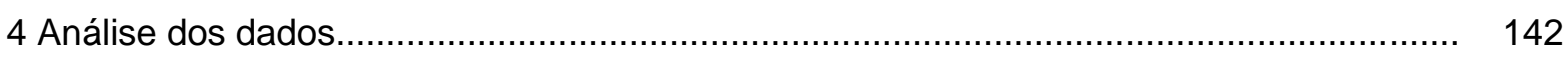

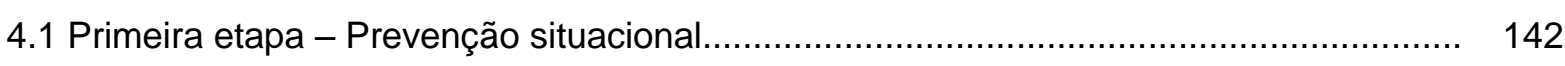

4.1.1 Dados sobre as instituições............................................................................... 142

4.1.2 Dados sobre as Coleções de obras raras............................................................... 146

4.1.3 Dados sobre segurança física das Coleções de obras raras....................................... 148

4.1.4 Dados sobre segurança eletrônica nas Coleções de obras raras................................ 152

4.1.5 Dados sobre as equipes de segurança e guarda de chaves...................................... 155

4.1.6 Dados sobre o controle do acervo................................................................... 156

4.1.7 Dados sobre os responsáveis pelas Coleções de obras raras.................................. 164

4.1.8 Análise das condições gerais de segurança nas instituições respondentes................. 168

4.2 Segunda etapa - Casos de roubo e furto de Livros Raros............................................ 169

4.2.1 Instituto de Pesquisas Jardim Botânico do Rio de Janeiro........................................ 170

4.2.2 Palácio do Itamaraty do Rio de Janeiro................................................................ 172

4.2.3 Museu Histórico Nacional do Rio de Janeiro.......................................................... 173

4.2.4 Museu Nacional da Universidade Federal do Rio de Janeiro (UFRJ)......................... 175

4.2.5 Biblioteca da Escola de Belas Artes (EBA) da Universidade Federal do Rio de

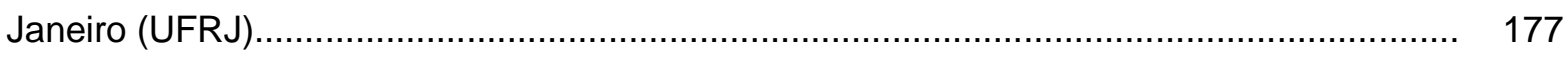

4.2.6 Arquivo Geral da Cidade do Rio de Janeiro (AGCRJ)........................................... 178

4.2.7 Biblioteca Mário de Andrade de São Paulo.............................................................. 179

4.2.8 Biblioteca Pública do Paraná............................................................................... 180

4.2.9 Museu Raimundo Ottoni de Castro Maya ou Museu Chácara do Céu do Rio de

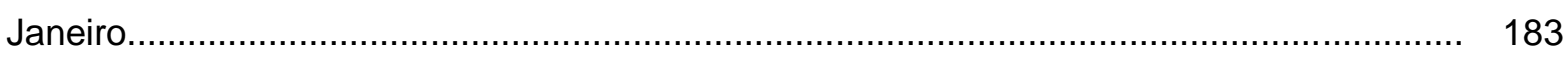

4.2.10 Fundação Oswaldo Cruz do Rio de Janeiro (FIOCRUZ) ...................................... 184

4.2.11 Instituto Geográfico e Histórico da Bahia (IGHB)................................................ 185

4.2.12 Museu Paraense Emílio Goeldi..................................................................... 186

4.2.13 Instituto de Botânica de São Paulo................................................................. 187

4.2.14 Centro de Ciências, Letras e Artes de Campinas (CCLA) ........................................ 188

4.2.15 Instituições que responderam positivamente à questão 75 , sobre desaparecimento

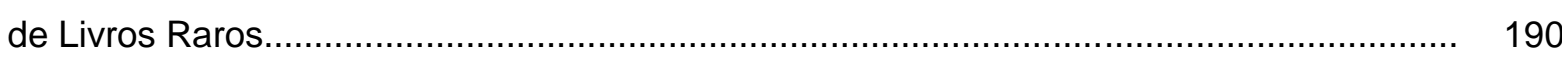




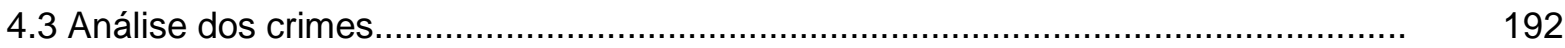

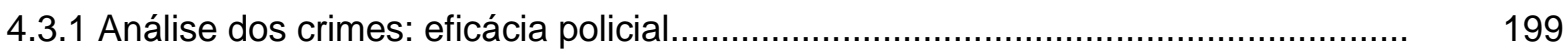



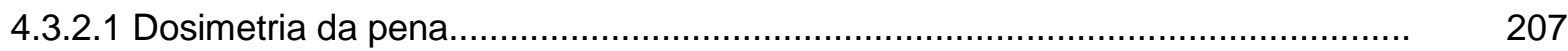

4.4 Terceira etapa - Entrevistas com especialistas, delegado da Polícia Federal e representantes do IPHAN................................................................................... 213

4.4.1 Análise das entrevistas............................................................................. 214

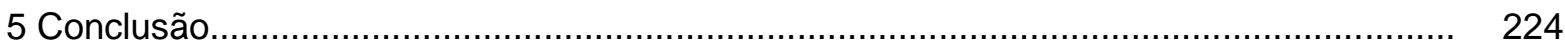

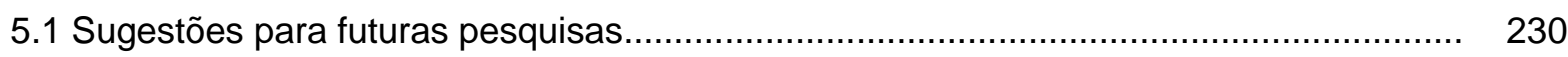

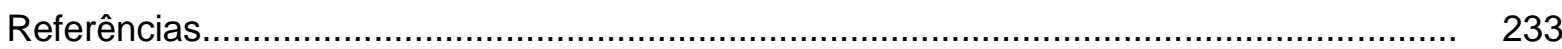

\section{Volume 2}

APÊNDICE A - Questionário sobre prevenção situacional............................................. 259

APÊNDICE B - Questionário às instituições com casos de roubo ou furto........................... 265

APÊNDICE C - Roteiro de entrevista com especialistas em segurança contra roubo e furto.

APÊNDICE D - Roteiro de entrevista com Delegado da Polícia Federal............................. 268

APÊNDICE E - Roteiro de entrevista com funcionários do Iphan........................................ 269

APÊNDICE F - Transcrição da entrevista com Entrevistado A.......................................... 270

APÉNDICE G - Transcrição da entrevista com Entrevistado B....................................... 292

APÊNDICE H - Transcrição da entrevista com Entrevistado C..................................... 303

APÊNDICE I - Transcrição da entrevista com Entrevistado D........................................... 332

APÉNDICE J - Transcrição da entrevista com Entrevistados E e F................................. 349

APÉNDICE K - Lista de obras furtadas e recuperadas do Palácio do Itamaraty do Rio de Janeiro......

APÉNDICE L - Lista de obras furtadas e recuperadas do Museu Nacional da Universidade Federal do Rio de Janeiro (UFRJ).

APÊNDICE M - Lista de obras furtadas no Arquivo Geral da Cidade do Rio de Janeiro (AGCRJ).

APÊNDICE N - Lista de obras furtadas e recuperadas da Biblioteca Mário de Andrade de São Paulo

APÊNDICE 0 - Lista de obras furtadas na Biblioteca Pública do Paraná.

APÊNDICE P - Lista de obras furtadas e recuperadas da Fundação Oswaldo Cruz do Rio de Janeiro (FIOCRUZ).

APÊNDICE Q - Lista de obras furtadas e recuperadas do Instituto Geográfico e Histórico 
da Bahia (IGHB)

ANEXO A - Lista de Instituições cadastradas no Planor................................................ 428

ANEXO B - Fontes bibliográficas para determinação de raridade de livros.......................... 434

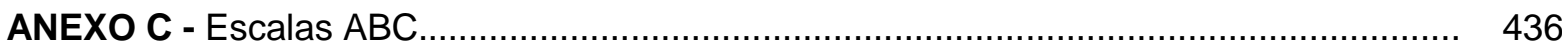

ANEXO D - Escala de magnitude de riscos.............................................................. 437

ANEXO E - Sentença do Processo ํㅜ 0517641-33.2004.4.02.5101 da $2^{\text {a }}$ Vara Federal Criminal do Rio de Janeiro.

ANEXO F - Sentença do Processo no 0807693-18.2009.4.02.5101 da 6 n $^{\mathbf{a}}$ Vara Federal Criminal do Rio de Janeiro.

ANEXO G - Sentença do Processo no 2007.0003086-7 da 11 aㅡ Vara Criminal do Foro Central de Curitiba no Paraná 


\section{Introdução}

Um livro raro é considerado como tal quando possui poucos exemplares e características que o diferencia dos livros comuns; ou seja, o simples fato de existirem poucos exemplares de uma obra não a torna automaticamente um livro raro, pois pode ter sido publicada por um autor desconhecido e seu conteúdo pode ser considerado irrelevante. No entanto, um livro considerado historicamente irrelevante por seu conteúdo e autor pode ser um livro raro, por exemplo, devido à importância de seu encadernador, que desenvolveu uma técnica revolucionária, tornando-se admirável para a posteridade. Ao mesmo tempo, pode existir um livro raro que não provoca admiração estética alguma, mas que abriga conteúdo informacional que revolucionou o pensamento humano.

O valor econômico de um livro está sujeito à importância histórico-cultural dada ao objeto e às variações de mercado. Portanto, um livro raro é mais valioso se houver uma associação de características de raridade, como, por exemplo, uma primeira edição de Harry Potter e a pedra filosofal, de 1997, que apesar de não ser antigo pelos parâmetros da história do livro, é um livro que influenciou muitos jovens, que, hoje adultos, gostariam de comprá-lo, mas que tem seu valor ainda mais elevado pelo fato de só terem sido impressos quinhentos exemplares, atingindo por isso a cifra de US\$ 30 mil (BARTLETT, 2013). O mercado tem demonstrado que os livros raros atingem altos valores venais, como o Birds of America, arrematado em dezembro de 2010, na casa de leilão Sotheby's, por US $\$ 11,542,683$.

Os roubos e furtos de bens culturais têm sido constantes e neste universo se encontra também a subtração de livros raros. Os crimes contra bens culturais diversos (quadros, esculturas, arte sacra, entre outros), apesar de não ser o objeto principal deste trabalho, serão apresentados aqui sucintamente para introduzir o contexto em que os roubos e furtos de livros raros estão inseridos. Em alguns casos de roubo e furto de bens culturais, são levados, por exemplo, livros e quadros, como nos crimes ocorridos no Museu Raimundo Ottoni de Castro Maya, no Rio de Janeiro, e no Centro de Ciência, Letras e Artes, em Campinas. Entre os crimes que envolvem a subtração de livros raros estão os roubos à Biblioteca Nacional da França entre os anos 2000 e 2003, na Yale University em 2005, no Museu Paraense Emílio Goeldi 
em 2008 e no Instituto de Botânica em São Paulo em 2012, mostrando que esta é uma prática que vem atingindo todos os países e pondo em risco o patrimônio histórico mundial.

No intuito de entender o comportamento criminoso e as variáveis que levam o infrator a cometer o crime, surgiram várias teorias. As teorias divergem quanto ao foco dado ao que consideram ser o principal agente motivacional sobre o indivíduo. Portanto, as teorias estudaram a influência de fatores psicológicos, biológicos, sociais e econômicos com relação a tal comportamento.

A Economia do Crime defende que a ação criminosa é racional e que o bandido leva em consideração uma relação custo $X$ benefício. Portanto, para que 0 crime não aconteça é preciso elevar os custos. Dentro da Economia do Crime, a Teoria da Dissuasão mostra que os custos podem ser elevados por meio de medidas legais e extralegais que aumentem a probabilidade de prisão e de condenação. Segundo a Teoria da Dissuasão, um alto índice de prisões, alto rigor penal e segurança adequada na prevenção situacional (defesas contra o crime nos alvos) diminuem as investidas criminosas.

Para entender como os efeitos de dissuasão estão sendo usados no contexto de livros raros no Brasil, foi analisado o rigor penal, por meio da legislação sobre patrimônio cultural, buscando os itens específicos sobre livros raros, além das condenações conhecidas de ladrões deste tipo de documento. Também foi analisada a eficiência policial, por meio de pesquisa documental, levantando o índice de prisões em relação aos casos conhecidos, o índice de recuperação das obras e, por entrevista, a experiência de um delegado da Polícia Federal e o seu modo de trabalho com este tipo de crime; assim como foi analisada a prevenção situacional, com aplicação de questionário, para averiguação da segurança contra roubo e furto nas instituições guardiãs de livros raros, levantamento documental para verificar os detalhes da ação criminosa e entrevistas com bibliotecários especializados no cuidado de livros raros e com membros do Instituto do Patrimônio Histórico e Artístico Nacional (IPHAN). 


\subsection{Hipótese}

O efeito de punição, de acordo com a Teoria da Dissuasão, foi apontado durante toda a contextualização teórica como fator importante na inibição do crime, elevando a percepção do criminoso quanto aos custos envolvidos no delito e a probabilidade de prisão. Levando em consideração esse pressuposto, a hipótese defendida por este trabalho é que o modelo atual de dissuasão (índice de prisão, índice de condenação, severidade da pena e prevenção situacional) referente aos crimes contra o patrimônio cultural age como facilitador do roubo ou furto de obras raras.

A hipótese apresentada possui mais de uma variável (eficácia policial, rigor penal e prevenção situacional), que possuem entre si uma relação de associação, pois "implicam diversos tipos de relações entre as variáveis, sem incluir relações de causalidade (influências): relações de reciprocidade, igualdade, superioridade, inferioridade, precedência etc." (RICHARDSON, 2011, p. 109).

\subsection{Objetivos}

No contexto relacionado à segurança de livros raros, as instituições guardiãs podem empregar medidas de prevenção contra roubo e furto como modo de inibição a esses crimes. Outros mecanismos que podem ajudar na prevenção desses atos são a legislação de proteção ao patrimônio cultural, a ação policial na recuperação das obras e prisão dos envolvidos, e o rigor penal na condenação dos criminosos. O modelo proposto pela Economia do Crime mostra, junto à Teoria da Dissuasão, mostra que os crimes podem ser freados com o aumento da percepção do indivíduo sobre a probabilidade de prisão e sobre os custos envolvidos no delito. Isso é, o rigor imposto pela legislação a um determinado tipo de crime e o índice de prisão dos envolvidos são fatores determinantes para a decisão de cometer ou não a transgressão. 


\subsubsection{Objetivo Geral}

Investigar o roubo ou furto de livros raros em instituições de cultura, ensino e pesquisa no Brasil, pela perspectiva da Teoria da Dissuasão no contexto da Economia do Crime.

\subsubsection{Objetivos específicos}

- Identificar e analisar os processos e a estrutura de segurança existentes nas instituições guardiãs de livros raros;

- analisar os casos de roubos e furtos de livros raros no Brasil;

- identificar e analisar o índice de recuperação dos livros raros roubados ou furtados;

- analisar a legislação pertinente ao contexto de livros raros e a consequente aplicação da lei no caso de roubos e furtos dessas obras;

- estabelecer relação entre a Economia do Crime e o roubo e furto de livros raros;

- identificar o índice de prisão e condenação dos autores de roubos ou furtos de livros raros.

\subsection{Justificativa}

Os livros têm atingido altos valores venais em leilões devido ao apreço dos colecionadores pelo seu conteúdo informacional e imagético, que refletem sua importância histórico-cultural. Esta admiração pelos livros raros se deve à escassez de exemplares de uma obra, que mudou algum aspecto da sociedade por seu conteúdo, ou que foi confeccionada com materiais exóticos ou preciosos, ou por conter gravuras de algum artista ilustre, ou por algum outro motivo que o torne diferente do livro comum. Algumas pessoas, além de admirarem o livro como objeto estético e informacional, ainda o enxergam como investimento, ou seja, preveem que, devido à sua importância histórica e cultural e por sua raridade, este item irá valorizar com o passar do tempo. 
A valorização dos livros raros atrai a atenção de criminosos que tentam lucrar por meio da subtração desses exemplares. Portanto, foi possível notar que existem muitas notícias recentes (século XXI) de casos de roubos e furtos de livros raros no mundo e no Brasil, representando uma perda histórica-cultural e econômica considerável. Essa atividade ilegal em que o criminoso enxerga a possibilidade de ganho econômico com a subtração de livros raros traz como consequência a dilapidação de parte do patrimônio histórico e cultural mundial e brasileiro.

Quando o livro raro é retirado da guarda de uma instituição de cultura, ou ensino ou de uma biblioteca, seja pública ou privada, que promove o acesso coletivo ao seu acervo, por meio do roubo ou furto, ocorre a privação do acesso a obra. Ou seja, um exemplar que antes tinha acesso público, passará ao acesso privado daquele que o subtraiu ou que o adquiriu ilegalmente. Pois, existirá o receio daquele que agora possui a obra em mostra-la a outras pessoas, devido ao modo como foi obtida. No caso dos livros raros ainda há uma escassez de exemplares associada, de modo que essa apropriação indevida pode significar a perda ou restrição completa de acesso da informação contida neles. A perda informacional torna-se mais significativa quando a obra pertence a uma instituição pública, pois toda uma nação tem impendido o acesso ao livro raro subtraído.

Segundo a Economia do Crime o ladrão irá agir de forma consciente sobre suas ações, ponderando os benefícios que serão adquiridos no roubo ou furto, com os custos envolvidos nesse crime. Os benefícios associados ao roubo ou furto de livros raros se dá no ganho econômico do criminoso, devido aos altos valores venais das obras. Já os custos vão depender de uma série de fatores associados à personalidade do indivíduo, sua criação, religião, nível de estudo, entre outros. Esses são custos morais, que são medidos conforme a aceitação ou não do próprio indivíduo e da sociedade sobre a atividade exercida. Entretanto, ainda existem outros custos que podem também estar associados ao gasto econômico envolvido na ação criminosa.

Para a Teoria da Dissuasão existem meios legais que podem elevar a percepção do ladrão sobre os custos envolvidos em suas atividades. Estes custos estão relacionados com a prevenção situacional (nível de proteção e segurança nos 
alvos dos crimes), à eficácia policial e o ao rigor penal. Portanto, para o criminoso será mais oneroso exercer a atividade ilegal caso os seus alvos estejam mais protegidos, pois, será mais difícil burlar um programa de segurança bem estruturado sem acabar sendo pego ou descoberto, de modo que isso irá exigir maior qualificação, planejamento e gastos dele. Assim como, caso a polícia seja eficaz na apreensão das obras subtraídas, toda a ação criminosa terá sido em vão, já que é impedido o ganho econômico do criminoso. Também a eficácia policial pode significar um alto índice de prisão dos ladrões, que poderá implicar em muitos anos de encarceramento caso a lei seja rigorosa para esse tipo de crime.

No contexto em que os benefícios econômicos e histórico-culturais dos livros raros só vão aumentando com o passar dos anos devido a tendência de diminuição de exemplares, torna-se importante saber como o modelo brasileiro atual de dissuasão está sendo empregado para tentar evitar o roubo e furto desses materiais. Ou seja, é preciso verificar as condições de segurança nas instituições brasileiras guardiãs de livros raros, analisando se as mesmas apresentam processos de segurança ativa e passiva, com o emprego de barreiras físicas e equipamentos eletrônicos, além de ter planos de segurança definidos, que visem a dificultar a ação criminosa. Assim como também é preciso analisar a ação policial no contexto dos crimes de roubo e furto de livros raros, para entender seu modo de atuação e verificar os índices de prisão dos criminosos e recuperação das obras. Consequentemente também é preciso analisar o rigor previsto em lei e aplicado na condenação dos criminosos que praticam o roubo e furto de livros raros.

O presente estudo visa a contribuir para uma melhor preservação do patrimônio cultural com a análise dos meios legais de proteção contra roubo e furto aplicados, principalmente pelo estado e união, mas não exclusivamente, nas atividades de segurança preventiva e paliativa. Ou seja, ao analisar as condições de segurança das instituições guardiãs de livros raros, este trabalho visa identificar em que aspectos elas podem melhorar ou reforçar sua segurança. Somando-se isso a análise da eficácia policial e do rigor penal, busca-se criar um conjunto de dados que permitam averiguar caminhos para reforço da segurança aos livros raros em âmbito nacional, por meio de ações individuais, institucionais e políticas. 


\section{Revisão de Literatura}

\subsection{Definição de livro raro}

Entre as características necessárias para que um livro seja raro, mas não a única, está a escassez de exemplares, seja intencional ou casual, por meio de sua trajetória histórica, pela baixa produção de itens de um mesmo título, por ter passado por censura, ou mesmo ter sido repudiado pelo autor. Além disto, a relevância histórica e cultural de um título também pode ser determinante para a atribuição de raridade, pois são levados em consideração aspectos relacionados à sua importância para uma área do conhecimento, para um povo ou nação e para a sociedade como um todo. Contudo, cada livro é um objeto particular com sua própria história, ou seja, os exemplares de uma mesma edição podem se diferenciar entre si pelas distintas mãos pelas quais passaram, ganhando também características extrínsecas à sua produção, como uma assinatura, anotação, Ex libris de alguma personalidade ou mesmo uma encadernação diferenciada pelo material usado na confecção, que podem caracterizar um livro como raro.

De maneira bem simplificada, pode-se dizer que livro raro é aquele difícil de encontrar por ser muito antigo, ou por tratar-se (sic) de um exemplar manuscrito, ou ainda por ter pertencido a uma personalidade de reconhecida projeção e influência no país e mesmo fora dele [...], ou reconhecidamente importantes para determinada área do conhecimento. (RODRIGUES, 2006, p. 115)

Antes da invenção da imprensa, em aproximadamente 1450 (MCMURTRIE, 1969), a produção ocidental de livros era feita de forma manuscrita, ou seja, como o próprio nome indica, a escrita e as ilustrações eram feitas à mão ${ }^{1}$ (em alguns casos as ilustrações eram feitas por gravura ${ }^{2}$ ). Somado ao árduo trabalho manual dos escribas, o método artesanal de fabricação do pergaminho e do papel fazia com que frequentemente fossem produzidos poucos exemplares de uma mesma obra. Além

\footnotetext{
${ }^{1}$ McMurtrie (1969, p. 79) diz "Naturalmente, o códice, tal com o rolo, era escrito à mão, e por isso estas duas espécies de livros antigos são conhecidas por 'manuscritos', da designação latina libri (ou codices) manu scripti, 'livros (ou códices) escritos à mão'".

${ }^{2}$ Febvre e Martin (2000, p. 122) afirmam "[...] a gravura em madeira - antes mesmo do aparecimento dos primeiros livros impressos: já verificámos ( $\mathrm{sic}$ ) que, a partir de finais do século XIV, as estampas xilográficas tinha $(\mathrm{sic})$ começado a espalhar-se $(\mathrm{sic})$ em grande número, e a indústria xilográfica vivia em pleno progresso quando apareceu a imprensa."
} 
disso, é possível observar nos manuscritos casos de alterações de conteúdo e estilo entre o original e a cópia, que transformam os já escassos exemplares em únicos ${ }^{3}$. Por isso, algumas bibliotecas como, por exemplo, a Biblioteca Central (BCE) da Universidade de Brasília $(\mathrm{UnB})^{4}$, consideram como obras raras estes manuscritos, mantendo-os na mesma coleção em que estão os livros impressos raros. Apesar disso, bibliotecas com uma grande quantidade de livros raros impressos e também de manuscritos (medievais ou modernos) preferem mantê-los em coleções separadas, como é o caso, por exemplo, da Biblioteca Nacional (BN) ${ }^{5}$.

Sant'Ana (2001) diz que os primeiros impressos, até o ano de 1500, chamados de incunábulos, são considerados livros raros pelas bibliotecas, como acontece, por exemplo, na Biblioteca Nacional, que desde seus primeiros critérios de seleção de obras raras, estabelecidos por Cunha $(1984$, fl. 1), já consideravam como tal as "primeiras impressões (séc. XV-XVI)".

As obras impressas até o final do século XVIII são consideradas raras por muitas bibliotecas, pois só houve a expansão do mercado livreiro no século XIX, de modo que as obras passariam a ter uma tiragem mais ampla para satisfazer a demanda ${ }^{6}$. Portanto, os livros anteriores a este período são considerados raros devido à fabricação praticamente artesanal. Sant'ana (2001, p. 5) mostra que "durante quase 350 anos, no período que vai de Gutenberg até o final do século $\mathrm{XVIII,} \mathrm{todos} \mathrm{os} \mathrm{livros} \mathrm{foram} \mathrm{produzidos} \mathrm{praticamente} \mathrm{do} \mathrm{mesmo} \mathrm{modo".}$

\footnotetext{
${ }^{3}$ McMurtrie (1969, p. 81) mostra que "os escribas estavam em regra proibidos de fazer alterações no texto, mesmo quando o original que estavam a copiar estivesse manifestamente errado. Mas os escribas monásticos eram simples seres humanos, e muitas vezes trabalhavam forçadamente numa tarefa que Ihes era desagradável, e por isso não é nada de admirar que o seu espírito por vezes devaneasse e cometessem erros."

${ }^{4}$ Informação retirada do portal da BCE/UnB. Disponível em: <http://www.bce.unb.br/acervo>. Acesso em: 15 fev. 2014.

${ }^{5}$ Informação retirada do portal da BN. Disponível em: <http://www.bn.br/portal/>. Acesso em: 04 ago. 2014.

${ }^{6}$ Labarre (1981) mostra que no século XIX houve mudanças na produção livreira que aumentaram a produção, com a mecanização da fabricação do papel e da prensa, com o surgimento da monotipia e com o aparecimento da fotografia.
} 
No Brasil, a imprensa só vai chegar definitivamente em 1808, com a vinda da Família Real, que resulta na criação da Imprensa Régia (MORAES, 2006). A data relacionada à produção livreira no Brasil adotada pelas bibliotecas como critério de seleção como livro raro é muito variada. Por exemplo, a Biblioteca Nacional (2000), considera como raros todos os livros publicados no Brasil até o ano de 1841; a Biblioteca da Universidade Federal do Rio de Janeiro leva em consideração o ano de $1900^{7}$; enquanto a Biblioteca Central da Universidade de Caxias do Sul adota até 1860 (RODRIGUES, 2006), e a Biblioteca Ministro Oscar Saraiva do Ministério da Justiça considera como livro raro todos os livros publicados até 1910, seja no Brasil ou no exterior (MENESES; SILVA, 2004).

Moraes (1965/2005) mostra que os livros que tratam sobre o Brasil passaram a ser mais procurados pelos colecionadores. Ele denominou a totalidade destas obras, até o ano de 1900, de Brasiliana. A partir desta procura, este passaria a ser um critério de seleção de livros raros adotado em várias bibliotecas brasileiras, como é o caso da Universidade de Brasília.

O valor cultural nem sempre está ligado à data de publicação, pois vários autores mais recentes se consagraram por suas ideias e modificaram suas áreas de conhecimento, como, por exemplo, o físico Albert Einstein: suas obras não se enquadram nos critérios relacionados a data, mas suas primeiras edições atingem um alto valor venal devido à importância de seu conteúdo ${ }^{8}$. Muitos são os critérios adotados para tentar identificar essas obras, independente do período em que foram produzidas, como mostra Rodrigues (2006), ao dizer que na Universidade Caxias do Sul foram estabelecidos como critérios as edições especiais, personalizadas, de luxo, censuradas, clandestinas e esgotas, assim como os exemplares com anotações manuscritas relevantes e os trabalhos monográficos originais elaborados por personalidades importantes. Critérios estes que não necessariamente estabelecem alguma relação com a data em que o livro foi publicado.

\footnotetext{
${ }^{7}$ Informação retirada do portal da Biblioteca: <http://www.cfch.ufrj.br/index.php/obras-raras>. Acesso em: 22 abr. 2012.

8 Albert Einstein viveu entre 1879 e 1955 e teve sua primeira obra "Folgerungen aus den Cappilaritätserscheinungen", publicada em 1901 (WHITTAKER, 1955).
} 
Reifschneider (2008) descreve outros critérios de seleção que tentam captar essas obras que possuem alto valor cultural como, por exemplo, a censura empregada a determinadas obras, pois várias foram queimadas quase que completamente por censores, como no período da Ditadura no Brasil. O autor também aponta raridade para obras repudiadas pelo autor, pois alguns chegaram a recolher e destruir livros que eles mesmos publicaram, por não os considerar à altura de seus escritos ou por qualquer outro motivo. Outro atributo qualificador de livros raros seria a encadernação de luxo, pois vários bibliófilos mandavam reencadernar seus livros com materiais nobres, como couro, metais e, por vezes, pedras preciosas. É claro que geralmente estas obras já tinham um valor cultural, histórico ou mercadológico que justificasse o gasto com tais artifícios.

Aspectos gráficos também podem tornar um livro raro, como o caso de um erro de impressão que transforma o texto em algo caricato ou proibido como, por exemplo, o descuido no prefácio do livro "Poesias Completas", de Machado de Assis, onde, na palavra "cegara", a letra "e" foi substituída pela letra "a", causando grande mal-estar no autor (REIFSCHNEIDER, 2008).

Pinheiro (2009a) resume bem a ideia do que deve ser levado em consideração ao identificar uma obra rara:

- Limite histórico: usa como referencial a história do livro, pois o livro assume um papel novo a cada século;

- Aspecto bibliológico: traz uma leitura do livro como objeto, com características além da informação textual, considerando-o em vários casos como obra de arte;

- Valor cultural: traz os pensamentos de uma época e por isso é importante para o entendimento histórico de uma nação ou povo;

- Pesquisa bibliográfica: pode revelar a escassez de um título e o situar dentro do contexto em que foi produzido, trazendo dados que muitas vezes não são possíveis de identificar no próprio exemplar, como tiragem, impressor, importância do ilustrador, do autor, entre outros aspectos; 
- Características do exemplar: são aquelas extrínsecas à publicação, verificáveis nas inserções, subtrações e complementações que foram adquiridas posteriormente à sua produção.

\subsubsection{O livro como objeto estético}

O livro é um dos mais bem sucedidos meios de transmissão do conhecimento, devido às suas características físicas, que o tornam de fácil manuseio, leitura e guarda. Vários materiais foram integrados e abandonados na fabricação do livro ao longo de sua história. Nas encadernações, usou-se couro dos mais diversos animais; usou-se também seda, veludo, renda, bordado, madeira, marfim, pedras preciosas e várias outras matérias-primas. $O$ design gráfico foi imensamente modificado dos manuscritos medievais aos dias atuais, seja no abandono do uso de letras capitulares, marcas de impressores, notas ou glosas marginais $^{9}$, assinaturas, reclamos ${ }^{10}$ e textos sobrepostos, seja na adoção de paginação e folha de rosto. Como suportes da escrita também foram usados pergaminhos, velinos ${ }^{11}$, madeira, ossos, seda, cetim, bambu e papéis de várias origens, como os trapos (de tecido de algodão) ou ainda os papéis hoje usados da polpa da madeira. Os cortes ${ }^{12}$ já foram locais de fixação do título, de composições artísticas, de queimaduras, de dourações ou marmorizações, além da técnica fore-

\footnotetext{
${ }^{9}$ Glosa marginal: composição muito mais estreita do que a do texto e em tipo menor, que ladeia as páginas na respectiva altura, como citação, nota ou explicação do texto. (FARIA; PERICÃO, 2008, p. 362)

${ }^{10}$ Reclamo: Para juntar as folhas de um caderno, colocada à direita do pé de sua última página, e repetida normalmente no texto como a primeira palavra da página que iniciava o caderno seguinte. (ARAÚJO, 2008, p. 252)

11 Velino: couro de vitela, mais liso e mais fino do que o pergaminho vulgar, reservado aos manuscritos de luxo; pergaminho virgínio; vitalinium; vitulus. [...] Era produzido a partir de couros de animais - vitela, cordeiro ou cabrito com quatro a seis semanas de vida. O mais fino velino, porém, era produzido de velino uterino. (FARIA; PERICÃO, 2008, p. 723)

${ }^{12}$ Corte: cada uma das superfícies que resulta de cortar, com a ajuda de um instrumento (guilhotina, cisalha, manualmente, dobradeira), os três lados do livro. O corte pode ser deixado todo em branco, dourado apenas na cabeça, jaspeado ou gofrado em todos os lados, o que acontece em encadernações cuidadas. (FARIA; PERICÃO, 2008, p. 208)
} 
edge painting, onde havia verdadeiras obras de arte escondidas que só podiam ser vistas com um movimento específico inclinando o corte.

Uma obra rara é como um objeto raro, seu valor é medido não só pelo conteúdo, mas principalmente pelo estado de conservação, marcas de propriedade, tipos de encadernação, anotações manuscritas, assinaturas, etc., características inerentes a cada exemplar de uma obra. (FROES, 1995, p. 55)

Inúmeros outros recursos foram usados para adornar o livro e fazer dele mais que suporte de informação, mas também objeto de arte, onde a composição visual muitas vezes é mais importante que o texto que carrega. As seixas ${ }^{13}$ foram enfeitadas; os cabeceados ${ }^{14}$ feitos a mão eram mais que proteção, tanto que em vários livros estão presentes os falsos cabeceados; e também falsas são algumas nervuras, que antes aconteciam em decorrência das costuras de sustentação dos cadernos e depois representavam os métodos de produção de uma época. Também evoluíram as ilustrações: das iluminuras, passando pelas gravuras e toda sua gama de técnicas até as fotografias em papel couché. Os formatos, também muito diversos, já foram rolos, códices ${ }^{15}$, lequeado, sanfonado, cartonado e tudo mais que a imaginação humana permitiu. Todos estes processos propositais como manifestação artística ou mesmo como medida de diminuição de gastos fizeram do livro objeto histórico em sua forma, com uma série de evoluções ao longo de sua trajetória, de modo que é possível, muitas vezes, situá-lo precisamente em determinada época somente pela apreciação de suas características físicas.

\footnotetext{
${ }^{13}$ Seixa: parte interior da pasta da encadernação que, no verso desta, sobra ao redor do corte do livro. Nas encadernações requintadas de livros antigos apresenta-se frequentemente ornamentada com motivos dourados ou gravados a ferros secos. (FARIA; PERICÃO, 2008, p. 658)

${ }^{14}$ Cabeceado (ou cabeçada): extremidade do lombo do livro junto ao corte; nas encadernações mais antigas ou de arte, era uma tira de seda ou algodão trabalhada a mão que era colocada na cabeça e no pé da lombada do livro para reforçá-la e adorná-la. Nas encadernações mais modernas, foi substituída por uma tira de tecido colada nesses lugares. (FARIA; PERICÃO, 2008, p. 117)

${ }^{15}$ Códice: do latim caudex, "tronco de árvore", por extensão "tábula de madeira", em conjunto reunidas em cadernos unidos por cordões ou anéis, de onde o significado de manuscrito ou reunião de manuscritos antigos (ARAÚJO, 2008, p. 342).
} 


\subsubsection{Encadernações}

As encadernações surgiram inicialmente como meio de proteção ao livro em suas mais diversas formas: nas tábulas de argila da Babilônia, nos rolos de pergaminho ou códices manuscritos ou impressos.

Encontram-se nas coleções assírias do Museu Britânico o que podemos chamar de primitivas encadernações: placas de argila, cozidas, cobrindo as lâminas de argila gravadas com inscrições cuneiformes. Estas placas já poderiam ser chamadas de encadernação, pois utilizavam elementos de união confeccionados em metal. (GONÇALVES, 2008, p. 34)

Os rolos de papiro dos gregos e romanos eram armazenados nas bibliotecas (biblio + theka, cofre para livros); eram cilindros feitos tanto de madeira quanto metal ou pedra, com capacidade para armazenar vários rolos, como aponta Bruchard (1999). No formato códice, primeiramente foram usadas finas tábuas de madeira para envolver os cadernos, substituídas posteriormente por encadernações de couro com os cantos reforçados em metal, com o umbílico ou broche (ponto metálico fixado no meio da encadernação) e com travas nas goteiras (cortes laterais), como tentativa de manter o livro afastado da umidade e evitar que o pergaminho ondulasse. As encadernações de livros destinados às bibliotecas recebiam também uma argola onde seria passada uma corrente que faria com que os mesmos ficassem presos às suas estantes, evitando que fossem roubados.

Figura 1 - Encadernação com cantoneiras e broche

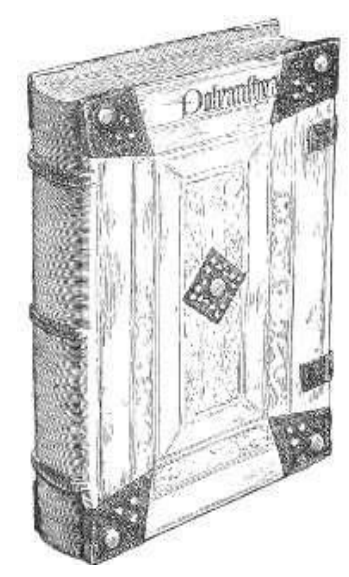

Fonte: MÁRSICO, 2010, p. 4. 
Mársico (2010) explica que, no período Bizantino, devido à expansão do Cristianismo, as capas dos livros tiveram a adição de pedras preciosas, marfim e/ou metais valiosos como modo de valorizar a palavra divina.

Figura 2 - Encadernação bizantina

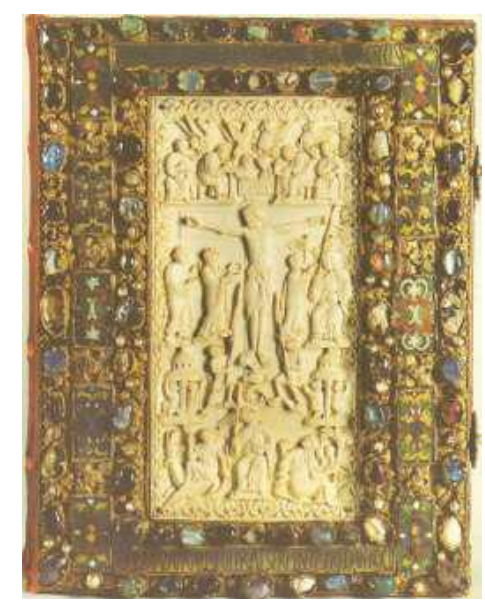

Fonte: MÁRSICO, 2010, p. 2.

$\mathrm{Na}$ Idade Média, a produção do livro é atividade quase que exclusiva dos mosteiros, que mantinham a tradição da produção do livro religioso desde o trato do pergaminho à cópia de algum manuscrito importante. As encadernações feitas nos mosteiros geralmente eram estampadas a seco por uma técnica chamada gofragem, onde não eram utilizados nem tinta nem ouro, sendo a estampagem obtida por meio de ferros quentes sobre o couro. As encadernações da Idade Média que possuem essa característica são conhecidas como encadernações monásticas.

Com a popularização tardia do papel na Europa, já que o mesmo surgiu no século II na China (ARAÚJO, 2008), e com a criação dos tipos móveis e surgimento da imprensa (século XV) ${ }^{16}$, os livros passaram a ser produzidos em maior escala e,

\footnotetext{
${ }^{16}$ McMurtrie (1969, p. 65) diz: "Parece estar fixada com aproximada exactidão (sic) a data da invenção do papel no ano 105 da era Cristã. Foi naquela altura que o novo processo foi comunidado (sic) pela primeira vez ao Imperador Ho Ti por Ts'ai Lun, a quem a tradição chinesa atribui a referida invenção". Enquanto Febvre e Martin (2000, p. 32) mostram que "A invenção da imprensa teria sido inoperante se um novo suporte do pensamento, o papel, proveniente da China através da Arábia, não tivesse feito a sua aparição na Europa, dois séculos antes, para ser de uso generalizado e corrente no final do século XIV".
} 
com isso, as encadernações foram barateando, principalmente por meio da substituição da madeira pelo papelão, proporcionando maior leveza ao livro. Aos poucos a produção do livro deixa de ser exclusividade dos mosteiros e passa a ser feita em ateliês.

Em Moraes (1965/2005) é possível ver uma breve história da encadernação por meio dos materiais empregados no seu fabrico. O autor mostra que as encadernações em veludo, chamalote ou couro trabalhado geralmente eram usadas como adereço de luxo, mandados confeccionar por um bibliófilo, que também tinha o costume, até o século XIX, de encadernar todos os seus livros com um único estilo de encadernação, que viria dar origem a diversos tipos hoje conhecidos. Moraes (1965/2005) mostra ainda que os editores e tipógrafos vendiam ao livreiro os volumes sem brochar e este último mandava encadernar apenas alguns exemplares para amostra, ou seja, à medida que iam vendendo, mandavam encadernar os demais, pois os bibliófilos preferiam comprar os seus sem encadernação, mandando fazê-la a seu gosto. Com a enorme produção no século XVIII, livros e folhetos que eram considerados sem valor permanente eram encadernados em brochura de papel barato em azul ou cinza. No século XIX, o costume passou à estampagem do texto da folha de rosto nas capas de brochura sendo vendidos os livros sem encadernação.

Devido às características de produção, pode-se estabelecer as encadernações dentro de uma linha evolutiva temporal e/ou estilística, onde vários encadernadores ficaram conhecidos por sua influência nesta arte. Mársico (2010) mostra que a douração nas capas surge no Marrocos no século XII e se populariza na Europa a partir do século XV. A autora ainda aponta diversos estilos ligados a esta técnica, como o Mudéjar que é predominante na Espanha, entre os séculos XII e XVI, tendo como principal característica a utilização de "cordas retorcidas", que permitiam diversos arranjos geométricos. 
Figura 3 - Estilo Mudéjar

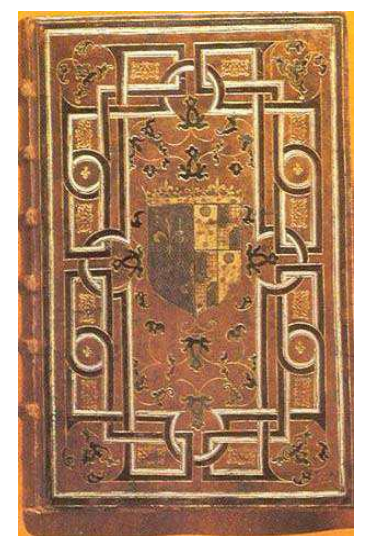

Fonte: MÁRSICO, 2010, p. 7.

O primeiro tipógrafo a ter seu nome ligado a um estilo foi Aldo Manuzio, que usava ferros em formato de folhas estilizadas terminando em espiral, num estilo sóbrio e elegante.

A Itália ainda teve outros estilos que ficaram conhecidos pelo nome do dono do livro e não pelo encadernador, como o caso de Canevari, que, além de bibliófilo, era mecenas das artes do livro, como informa Bruchard (1999). As encadernações Aldinas inspiraram Jean Grolier em suas viagens à Itália e, ao retornar à França, tratou de criar o seu próprio estilo por meio dos florões.

Figura 4 - Estilo Grolier

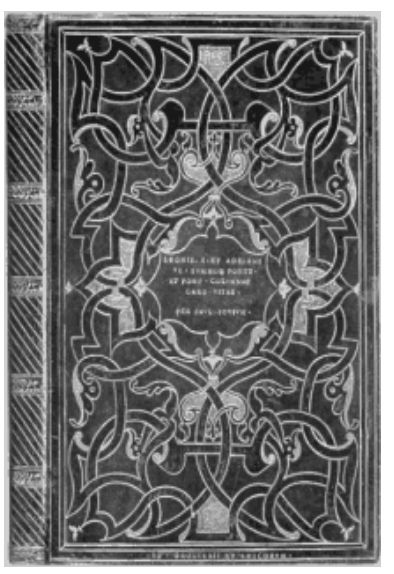

Fonte: BRUCHARD, 1999, p. 1. 
Outro representante francês foi Thomas Maioli, muito influenciado por seus antecessores, modificando os ferros para Ihes acrescentar pontilhados ao fundo. Também usou, com frequência, figuras geométricas, que, por meio de ferros curvos e florões com filete duplo, trouxeram um maior refinamento à composição artística de suas encadernações.

Figura 5 - Estilo Thomas Maioli

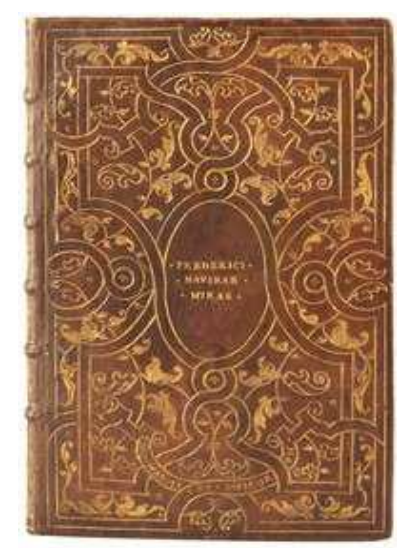

Fonte: MÁRSICO, 2010, p. 11.

No estilo La Fanfare também era recorrente o uso de folhas, flores e ramos espiralados cobrindo toda a encadernação. Ele teve como grandes representantes Nicolas e Cloves Éves, pai e filho, que trabalhavam como encadernadores para o rei.

Figura 6 - Estilo La Fanfare

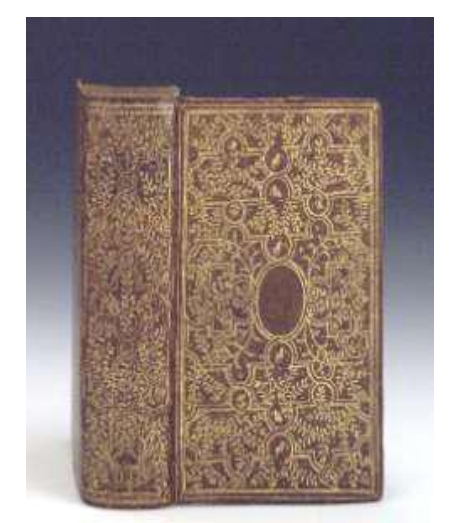

Fonte: MÁRSICO, 2010, p. 12. 
Augustin Du Seiul (1673-1740) usava filetes contornando a capa, formando um retângulo na beira da encadernação, e outro retângulo ao centro, com florões nos vértices.

Figura 7 - Estilo Du Seiul

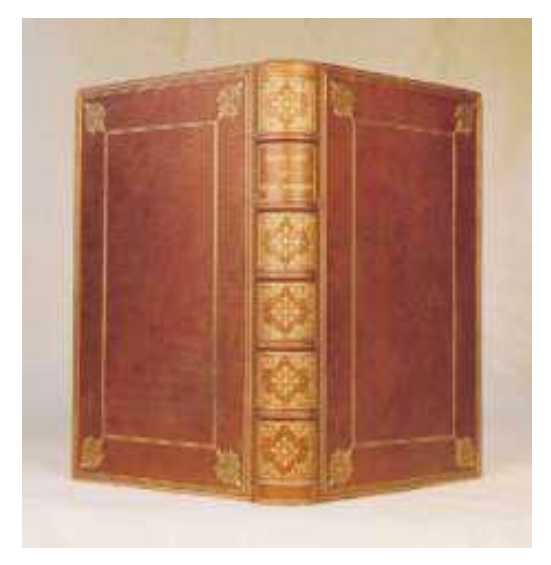

Fonte: MÁRSICO, 2010, p. 13.

Outros estilos consagrados são: Dentelle, Le Gascon e Padeloup, o primeiro com ornamentos que lembram rendilhados tendo como grande nome Nicolas Denis Derôme, e os outros dois usavam o pontilhado como recurso; no estilo Padeloup predomina a repetição, formando mosaicos.

Figura 8 - Estilo Le Gascon

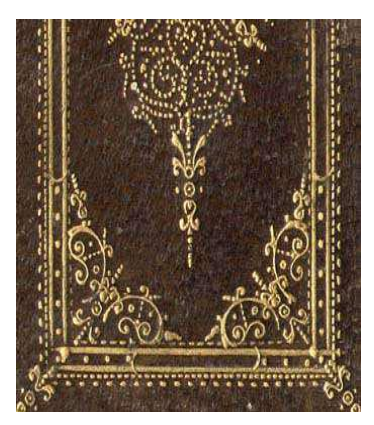

Fonte: MÁRSICO, 2010, p. 15. 
Figura 9 - Estilo Padeloup

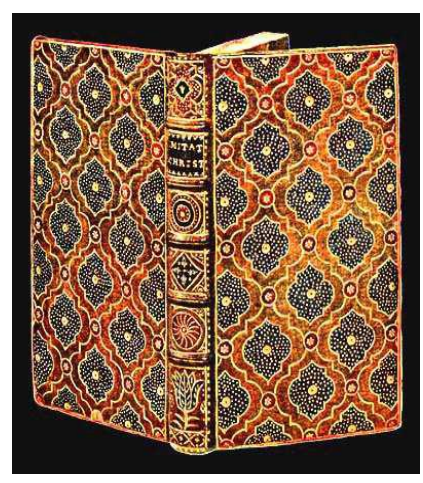

Fonte: MÁRSICO, 2010, p. 16.

As encadernações chinesas e japonesas se destacam pelo uso recorrente da costura aparente, onde a mesma não fica sobreposta pela lombada como acontece com as do ocidente.

Figura 10 - Encadernação oriental

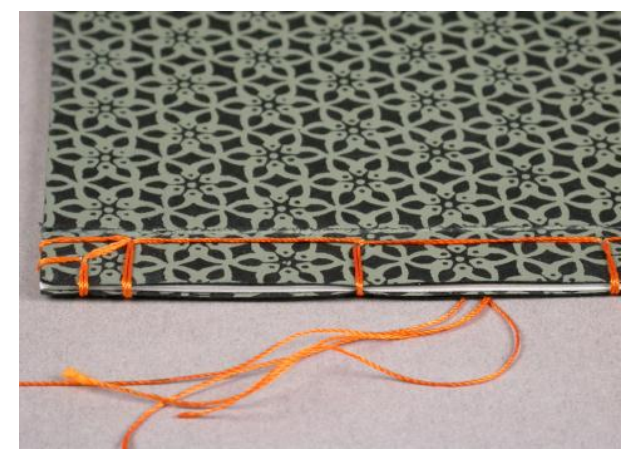

Fonte: MÁRSICO, 2010, slide 94

No Brasil, um estilo bastante conhecido é a encadernação imperial, tendo como característica principal a colocação do brasão do Império em dourado no centro da capa, que geralmente era da cor verde, mas também feita de outras cores, como azul, vermelho e roxo (MORAES, 1965/2005). Geralmente eram confeccionadas com couro, mas também foram usadas sedas e veludos. 
Figura 11 - Encadernação Imperial

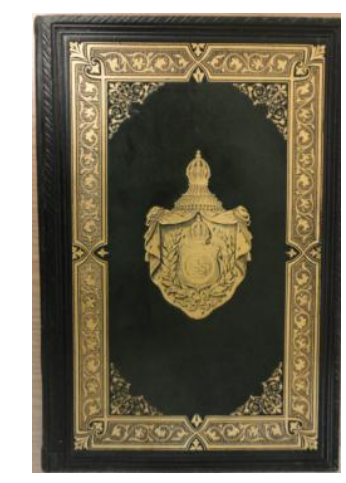

Fonte: CALDEIRA, 1884, Capa.

Moraes (1965/2005) mostra que as encadernações imperiais geralmente eram usadas nas repartições públicas e que não faziam parte da biblioteca do imperador como muitos acreditavam.

Apesar da encadernação brasileira não contar com nomes associados a qualquer outro estilo que não à encadernação imperial, como aconteceu com os já citados Thomas Maioli, Augustin Du Seiul, Nicolas Denis Derôme, entre outros, não significa que por aqui não existiram bons encadernadores que apresentassem um trabalho de qualidade. Por exemplo, os irmãos Morange, no início do século XIX, são citados por Moraes (1965/2005) pelos seus belos trabalhos identificados com uma elegante etiqueta. Assim como Geor Leuzinger, por volta de 1840, que, além de produzir encadernações imperiais, fazia belos trabalhos particulares, devido principalmente à qualidade dos materiais e maquinários empregados, quase todos importados. De sua oficina saíram vários aprendizes, que depois se estabeleceram e divulgaram a arte pelo país. Também são citados pelo autor os trabalhos de Garnier $^{17}$, que, como outros livreiros, enviava os volumes para encadernação na França; por vezes usava o brasão do Império como adorno, dificultando o reconhecimento do que era feito em território brasileiro das versões estrangeiras.

O Modernismo foi outro período no Brasil que teve influência nas artes gráficas e na confecção das capas, pois vários dos seus representantes ilustraram

\footnotetext{
${ }^{17}$ Hallewell (2012) diz que B. L. Garnier faleceu em 1893 e que a livraria Garnier Frères funcionou no Brasil de 1844 a 1934.
} 
as encadernações (principalmente os escritores do movimento), trazendo as inovações propostas para as artes brasileiras e o sentimento de patriotismo tão vívido naquele momento, como apontado por Knychala (1983).

Figura 12 - Encadernação Modernista

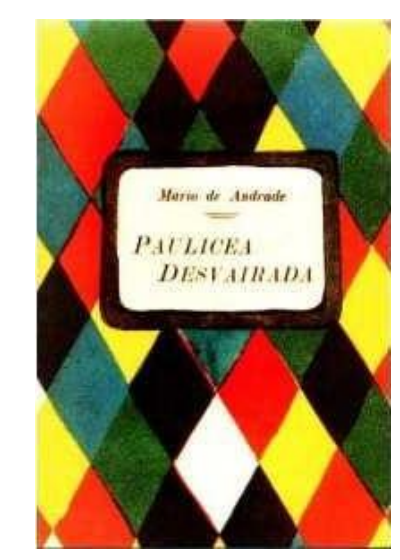

Fonte: ANDRADE, 1922, Capa.

\subsubsection{Ex libris}

O Ex libris, expressão latina que significa "dos livros de", é um selo de propriedade, anexado geralmente na contracapa dos livros. Nesta marca está uma figura sobre algum tema ou estampa com temática relevante ao dono do livro, ou brasões familiares, ou mesmo desenhos eróticos (sex libris, ex eroticis), que se torna "expressão de uma estética das senhas pessoais de identidade" (BERTINAZZO, 2012, p. 25). Estas ilustrações, não raro, são feitas em gravuras, por artistas de renome, de modo que esta figurinha que visa a identificar a quem o livro pertencia também é frequentemente admirada como objeto de arte, pelas técnicas de impressão e estética.

Várias são as instituições que atribuem um Ex libris ao seu acervo, como a Biblioteca Nacional do Rio de Janeiro, que possui Ex libris próprio e o aplica em suas obras. Também há casos do Ex libris atribuído: que acontece muito quando as bibliotecas incorporam ao seu acervo as coleções de pessoas ilustres, e a própria biblioteca cria um Ex libris para este acervo, que tem geralmente como função 
identificar a sua proveniência. Podem ser encontrados em alguns livros mais de um Ex libris, o que ajuda a traçar a trajetória histórica do objeto, pois são reconhecíveis seus diversos donos. Muitas obras são consideradas raras simplesmente por terem o Ex libris de alguém importante ou feito por algum artista conhecido, tornando assim mais uma parte do livro cobiçada pelos colecionadores.

Elton e Fernandes (1953) traçam um breve histórico do Ex libris, apontando como registro mais antigo do seu uso o ano de 1400 a.C., por Amenófis III, em uma caixa de papiros; enquanto a forma atual teria origem na Alemanha, no século XV, sendo o representante mais antigo o ouriço xilogravado, produzido a pedido de Johannes Hans Knabensberg, ou Hans Igler (ouriço) como era conhecido, em 1450 como mostra Bertinazzo (2012).

Figura 13 - Ex libris de Igler

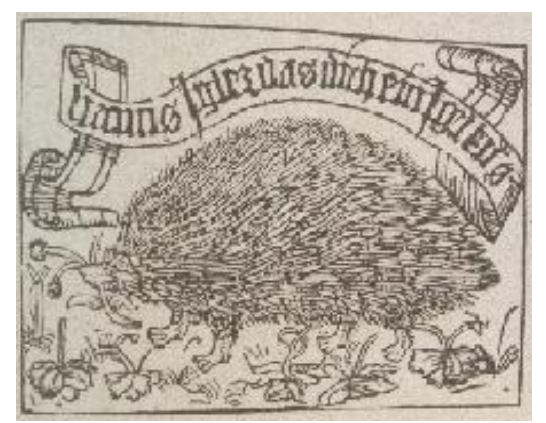

Fonte: BERTINAZZO, 2012, p. 53.

Esteves (1956) diz que, apesar de alguns acreditarem que o Ex libris pertencente a Igler seja o primeiro, há outros que situam como precursora a etiqueta usada por Hildebrando Brandenburgo (gravura em madeira representando um anjo a segurar um brasão em armas, produzida provavelmente entre os anos de $1470 \mathrm{e}$ 1480). O autor ainda afirma que esta opinião é compartilhada, inclusive, por Frederick Warnecke, autoridade no assunto. 
Figura 14 - Ex libris de Hildebrando de Brandenburgo

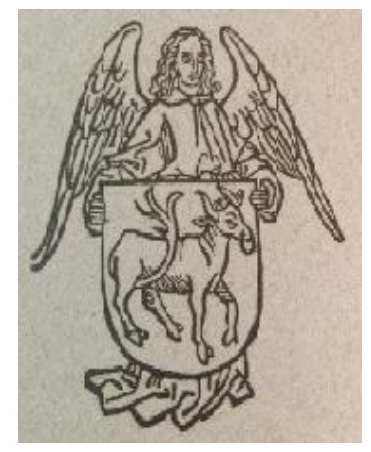

Fonte: BERTINAZZO, 2012, p. 54.

A respeito da discussão de qual seria o primeiro Ex libris, Bertinazzo (2012) diz que foi preciso um raciocínio elaborado para associar a gravura a uma marca e depois ao livro, sendo sua função primária a de atestar posse e em seguida de lembrar àqueles que pegaram o livro emprestado da sua devolução. Portanto, a data do Ex libris de Igler é posta em questão, pois sua confecção coincide com o surgimento da imprensa de Gutenberg; ou seja, a autora diz que este objeto seria afixado em alguns incunábulos e manuscritos, que provavelmente não eram emprestados devido à sua escassez e preciosidade, não necessitando assim de uma marca de propriedade.

Segundo Elton e Fernandes (1953), no Brasil, o uso de Ex libris foi iniciado por Diogo Barbosa Machado, cuja biblioteca particular foi incorporada ao acervo da Biblioteca Nacional no Rio de Janeiro. O autor diz que os dois exemplares de Ex libris deste bibliófilo foram gravados em Lisboa em 1730 por Francisco Harrewyn, que havia se instalado em Portugal a pedido de D. João V para criar, juntamente com outros gravadores estrangeiros, uma escola de gravura nacional. No entanto, o primeiro Ex libris genuinamente brasileiro foi o de Manuel de Abreu Guimarães, desenhado pelo padre José Joaquim Viegas de Menezes, no final do século XVIII (BERTINAZZO, 2012).

Várias instituições também usaram etiquetas como marcação de propriedade, tais como: Biblioteca do Arquivo Militar, Biblioteca da Sociedade do Recreio dos Artistas, Biblioteca Fluminense, Biblioteca do Instituto Histórico e Geográfico Brasileiro, além das bibliotecas particulares do Visconde de Porto Seguro (Francisco 
Adolfo de Varnhagen) e da Imperatriz do Brasil D. Tereza Cristina (ELTON; FERNANDES, 1953). Várias pessoas ilustres passam também a adotar seus selos, como o Visconde do Rio Branco, o Barão Homem de Melo, Salvador de Mendonça, Eduardo Prado e Joaquim Nabuco, entre outros, como mostram Elton e Fernandes (1953).

O primeiro colecionador brasileiro de Ex libris foi o Barão do Rio Branco, que teve sua coleção encontrada no final do livro Les ex libris français depuis leur origine jusqu'à nos jours, de Poulet-Malassis, em folhas acrescentadas a este volume, num total de 93 etiquetas, adquiridas principalmente no estrangeiro, em suas missões diplomáticas (BERTINAZZO, 2012). Elton e Fernandes (1953) mostram que o Ex libris do Barão demonstra a paixão deste homem por sua terra e por esta arte, com a representação da Baía de Guanabara e a pedra da Itapuca, desenho inspirado em uma fotografia desta paisagem feita por Marc Ferrez e publicada no livro Albun de Vues du Brésil, em 1889, com direção do próprio Barão do Rio Branco.

Figura 15 - Ex libris de Barão do Rio Branco

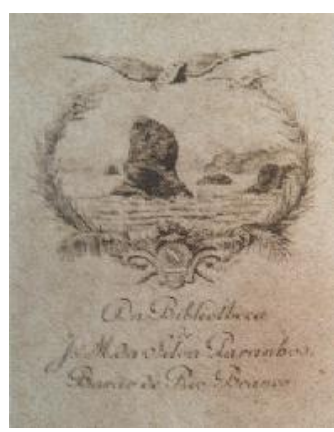

Fonte: BERTINAZZO, 2012, p. 26.

Bertinazzo (2012) mostra que na metade do século XX é que esta prática tem seu ápice no Brasil com a criação da Sociedade de Amadores Brasileiros de Ex libris, em 1940, e com a criação do Clube Internacional de Ex libris em 1944. Em 1949 é feita a primeira exposição municipal no Salão Assírio do Teatro Municipal do Rio de Janeiro, sendo confeccionado o catálogo da exposição e, em 1952, foi elaborada a primeira exposição estadual, no Espírito Santo. 
Floriano Bicudo Teixeira classificou os Ex libris quanto à natureza de seu assunto, como aponta Azevedo (2002):

- $\quad 1^{\text {a }}$ categoria: etiqueta propriamente dita, seja simples ou ornamentada, tipográfica ou reproduzida por qualquer processo artístico ou mecânico;

Figura 16 - Ex libris de Pedro Nava

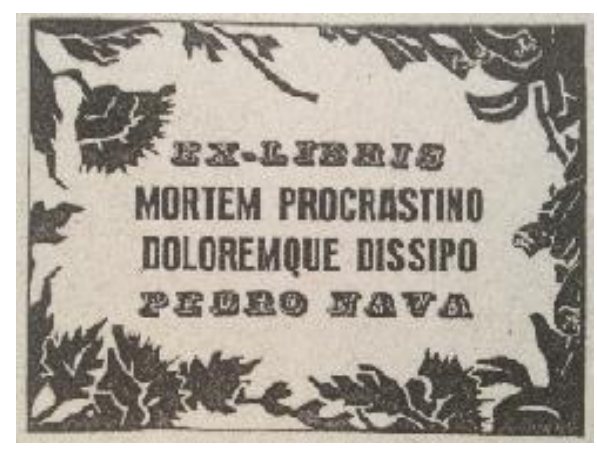

Fonte: BERTINAZZO, 2012, p. 193.

- $\quad 2^{2}$ categoria: Ex libris Armoriados ou heráldicos, quando o motivo principal consta de brasões ou insígnias de indivíduos, cidades, associações, etc.

Figura 17 - Ex libris de Francisco de Assis Carvalho Franco



Fonte: EX-LIBRIS, 2002, p. 29.

- $3^{\text {a }}$ categoria: Ex libris Simbólicos, quando traduzirem ideias, aspirações, lemas de vida e de ação, ocupações habituais (quando sem caráter heráldico, bem entendido), etc. 
Figura 18 - Ex libris de Th. Alexander

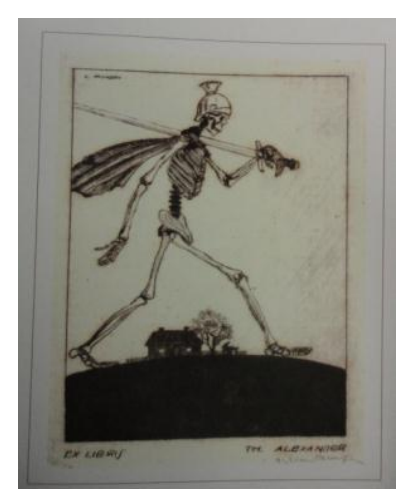

Fonte: EX-LIBRIS, 2002, p. 59.

- 4a categoria: Ex libris Paisagísticos, quando reproduzirem aspectos e cenas rurais, urbanas, de marinha, etc., ligadas afetivamente ao possuidor dos livros.

Figura 19 - Ex libris de Francisco Marques dos Santos

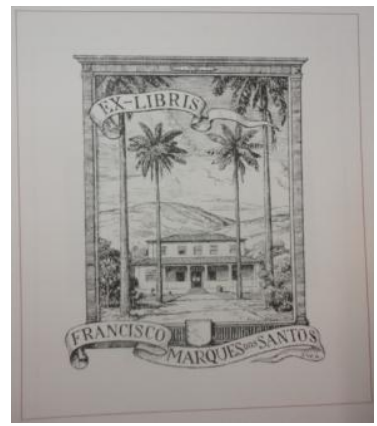

Fonte: EX-LIBRIS, 2002, p. 209.

O Ex libris, portanto, é um objeto que possui relação direta com o livro, mas é colocado posteriormente à sua publicação. Apesar de ser uma característica extrínseca à produção do livro, o Ex libris tem o poder de elevar a importância do exemplar por associá-lo a uma personalidade que tenha sido seu dono, ou ainda a um artista que tenha confeccionado o selo.

\subsubsection{Os livros e as ilustrações}

As imagens acompanham os livros desde a sua invenção, antes mesmo da popularização do formato códice, como ainda hoje é usado. As iluminuras já estavam presentes tanto nos rolos de papiro quanto nos manuscritos em 
pergaminho. Estes desenhos feitos à mão não serviam somente para ilustrar o livro, já que na Europa medieval, antes do advento da imprensa na metade do século $\mathrm{XV}^{18}$, o número de analfabetos era muito superior àqueles que dominavam a escrita e a leitura, conhecimento este concentrado majoritariamente entre os eclesiásticos. As ilustrações tomavam para si o objetivo de traduzir o conteúdo do texto para aqueles que não sabiam ler, ou seja, ela era elaborada para "iluminar" as mentes dos leigos diante do assunto tratado naquele manuscrito. Essa passagem demonstra o poder da imagem presente em meio ao texto de um livro e dá a dimensão de quão bem executados eram estes desenhos, trazendo consigo as características artísticas da época.

Com a popularização dos tipos móveis, as ilustrações também foram se tornando impressas, muito, em parte, para a diminuição do tempo de produção, usando, a princípio, a técnica da xilogravura ${ }^{19}$, que, por muito tempo, foi marca dominante nos livros. Estas gravuras estavam presentes em todas as alegorias no livro, seja na marca do impressor, nas letras capitulares ou mesmo nas vinhetas ornamentais ao longo do texto. As calcogravuras (gravuras em metal) aos poucos foram substituindo as gravuras em madeira. Araújo (2008) mostra que a gravura a entalhe sobre placas de metal consiste em colocar a pigmentação nas cavidades e não mais no relevo, como na xilogravura, recebendo várias denominações dependendo do material e/ou instrumento usado para inscrever o desenho, como nos casos do buril, talho doce, ponta seca, água-forte, água-tinta, entre outras

\footnotetext{
${ }^{18}$ McMurtrie (1969, p. 135-157) mostra a dificuldade em precisar assertivamente a autoria e datas dos primeiros impressos ocidentais. Mas mostra que Johann Gutenberg é o "pretendente mais firmemente considerado à honra de ser o inventor da imprensa", e que as evidências disso estariam compreendidas no "Fragmento do julgamento do mundo", datado entre 1444 e 1447, em um calendário do fim de 1447, às três edições de Donato com data estimada anterior a 1458 e na Bíblica de 36 linhas, impressa por volta de 1460 ou pouco antes, com indícios de que se começou a imprimir em 1450, sendo deixada de lado por um tempo e retomada a impressão por volta de 1457, quando Johann Fust, antigo sócio de Gutenberg, e Peter Schoeffer terminariam a Bíblia de 42 linhas, com tipos desenvolvidos provavelmente por Gutenberg.

${ }^{19}$ Xilogravura: "impressão mediante uma forma (bloco) de madeira, geralmente cortada no sentido da fibra (veios), em cuja superfície, perfeitamente nivelada, se cavam (sic) as áreas a não imprimir, ficando entalhados em relevo os elementos da imagem, que depois de entintados se imprimem sobre papel ou cartolina. Essa modalidade de gravura ilustrou alguns textos tipográficos até finais do século XIX e ainda hoje é cultivada por alguns ilustradores (FARIA; PERICÃO, 2008, p. 733).
} 
técnicas ${ }^{20}$. Para as ilustrações também são usadas as litografias e as serigrafias, que são técnicas que não exigem gravação de uma matriz.

Na litografia, pelo contrário, tudo se processa no plano, inclusive o desenho,
que é executado com lápis ou bastões gordurosos sobre pedras ou chapas.
Após o desenho feito na pedra, esta deve receber água, pois o princípio de
impressão se baseia na repulsão entre esta e os corpos gordurosos. A
pedra umedecida permite que a tinta graxa, passada com um rolo, se
agregue somente nas partes que contêm o desenho, também executado
com lápis graxo. (MARTINS, 1987, p. 19)

Araújo (2008) possibilita verificar o impacto e a evolução das ilustrações nos livros passando das gravuras aos processos fotográficos. As xilogravuras predominam principalmente do século $\mathrm{XV}$ ao $\mathrm{XVI}$, surgindo obras que já traziam excelente interação entre texto e imagem, como $A$ divina comédia, ilustrada por Botticelli, em 1481. Também surgem as primeiras pranchas desdobráveis, em 1486, no livro Pregrinationes in Terram Sanctan, ilustradas por Rewich. O declínio das xilogravuras vem com o surgimento da técnica do talho-doce, inventada por Maso Finigrerro em meados do século XV, largamente usada apenas a partir da invenção da laminagem, que permitiu a diminuição da espessura das placas usadas (ARAÚJO, 2008). O autor ainda mostra que as calcogravuras figuraram como técnica principal de ilustração entre os séculos XVI e XVIII, quebrando sua hegemonia a partir da criação das litografias por Alois Senefelder no final do século XVIII, técnica que futuramente originaria o offset, método preferido de impressão nos dias atuais. Todas as técnicas de gravuras coexistiram e, apesar da predominância de uma técnica sobre outra em determinado período histórico, vários artistas utilizavam as demais técnicas para expressar sua arte.

No século XIX começam as descobertas dos processos fotográficos, onde elementos sensibilizados pela luz podiam reproduzir imagens da natureza. Araújo (2008) ainda explica que, em 1827, são criadas, por Joseph Nicéphore Niepce, as chamadas Heliogravuras, por meio da reprodução em chapas de estanho

\footnotetext{
${ }^{20}$ Como exemplo, segue a definição de uma das técnicas, a água-forte: "documento impresso em talho-doce por meio de uma placa de cobre, zinco ou ferro revestida inicialmente de um verniz resistente ao ácido. O desenho é realizado por incisão do verniz. A gravura é obtida expondo mais ou menos a placa à mordedura do ácido, o qual provoca, por corrosão, a mordedura das zonas escavadas. De forma abreviada, chama-se água-forte a prova de uma estampa feita por este processo". (FARIA; PERICÃO, p. 39).
} 
sensibilizadas por uma substância chamada betume-da-judeia, utilizada até então pelos litógrafos. Niepce viria a se associar, em 1829, a Louis Jacques Mandé Daguerre, que teria o nome ligado à técnica por ele inventada em 1837, os daguerreótipos, que eram obtidos com uma chapa sensibilizada por iodeto de prata, revelando imagens pela ação de vapores de mercúrio e fixando a imagem pelo cloreto de sódio. Em 1841, William Henry Fox Talbot obteve um sistema de negativopositivo usando papel sensibilizado por iodeto de prata, processo chamado por ele de calótipo, que é justamente a fotografia como hoje é conhecida. No Brasil, Antoine Hercule Romuald Florence, ao descobrir sobre a técnica do daguerreótipo, faz declaração pública de sua descoberta, a qual denomina fotografia, termo que só seria amplamente usado depois de pronunciado pelo astrônomo John Frederick Williams Herschel. A partir da morte de Daguerre, em 1851, na tentativa de escapar do monopólio imposto por ele e Tabot por suas patentes, Frederick Scott Archer inventa a técnica do colódio úmido, onde uma camada de potássio sobre chapas de vidro, mergulhadas em dissolução de nitrato de prata formavam uma superfície fotossensível de iodeto de prata. Anos mais tarde, Louis Lumière inventaria a chapa autocromática, que daria origem às fotografias coloridas a partir de uma única película (ARAÚJO, 2008).

$\mathrm{Na}$ indústria editorial, a princípio, as fotografias eram colocadas nos espaços em branco das páginas, previamente estabelecidos para sua fixação, ou ainda reproduzidas por litografia, passando a ser inseridas impressas diretamente na página somente a partir da década de 1880. A massificação do uso das ilustrações nos livros ocorreu não sem resistência daqueles que acreditavam que o texto já era representativo visualmente, com o receio de que as imagens sobrepusessem 0 conteúdo.

\subsubsection{Livros de artistas e confrarias}

Vários artistas de renome utilizaram das técnicas de gravura aplicadas ao livro como fonte de expressão e propagação de sua arte. 
As edições de livros eram ilustradas no século XIX por artistas como Delacroix, Gustave Doré, Tolouse Lautrec, William Morris e posteriormente no século XX por artistas como Picasso, Matisse, Miró, Marc Chagall, Andre Derain, Sonia Delaunay, Leger, Eric Gill, Dufy, André Masson, Dalí e Rouault entre outros. (BARRIOS, 2008, p. 788)

O chamado livre d'art ou livre d'artiste (livro de arte ou livro de artista) surgiu pela mobilização das gráficas particulares contra a produção das gráficas comerciais no final do século XIX, já que estas últimas não primavam pela excelência gráfica e visual de suas obras destinadas à venda em massa.

Podemos considerar o livro de arte como sendo o livro que, além de
símbolo cultural com valores semânticos, apresenta-se como um objeto com
valores artísticos tais como boa qualidade e beleza do papel, dos caracteres
tipográficos e da encadernação, arquitetura e diagramação harmoniosas e
não necessariamente ilustrado; mas se contiver ilustrações, são
consideradas não só as ilustrações feitas com processos manuais, como a
xilogravura, a gravura em metal, a litografia e a serigrafia, como também
fotografias artísticas e reproduções por processos fotomecânicos.
(KNYCHALA, 1983, p. 25-26)

Araújo (2008) aponta William Morris e sua gráfica particular Kelmscott Press, fundada em 1891, como expoente na produção dos livros de arte e que por sete anos promoveu um retorno às técnicas artesanais de produção de livros, com a adoção das gravuras e iluminuras como método de ilustração, além da tiragem reduzida a menos de 350 exemplares. Esta iniciativa inspirou a mudança visual na construção da página e o surgimento de várias outras gráficas particulares que seguiam a mesma linha de produção, com repercussão em toda a Europa e nos Estados Unidos. Neste momento é que grandes pintores passam a se associar à criação de livros, dando às ilustrações um novo patamar, com maior autonomia em relação ao texto, passando de ilustrações à característica determinante no entendimento do texto. Esta revolução serviu para que as técnicas de gravura pudessem sobreviver paralelamente às fotografias no contexto do livro.

Seguindo o padrão adotado por Morris, várias foram as sociedades ou confrarias que surgiram com o intuito de criar livros que sobressaíssem pela técnica de produção empregada. Com uma preocupação estética com a diagramação, impressão, qualidade do papel, encadernações e técnicas de ilustração, estes grupos produziram vários livros considerados, desde a sua criação, como obras de arte. 
Para Paiva (2010), dentro do conceito de livro de artista, incluem-se subcategorias como os livros-objeto (livre-jeu, como são conhecidos na França), flip book, livro pop-up e fore-edge book. No primeiro estilo predomina a inventividade, trazendo a experimentação como modo de estímulo visual, manipulando os sentidos do leitor ao trabalhar e modificar o livro clássico, transformando-o em uma mescla de escultura, fotografia, literatura, desenho, etc.

Figura 20 - Censored book

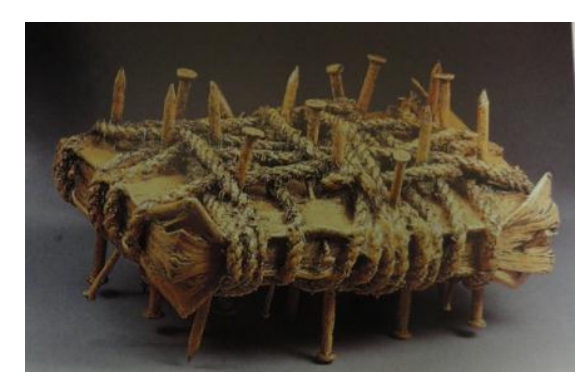

Fonte: BOOK ARTS, 1990, p. 10.

O flip book é aquele livro animado, tentando ser um paralelo do cinema, por meio da animação de imagens que, ao se folhear o livro, dão a impressão de movimento. Outras duas categorias apontadas por Paiva (2010) são: livro pop-up, oriundos do origami, e kirigami, que trabalha com dobraduras e cortes de papel transformando as páginas em figuras tridimensionais.

Figura $21-A B C$

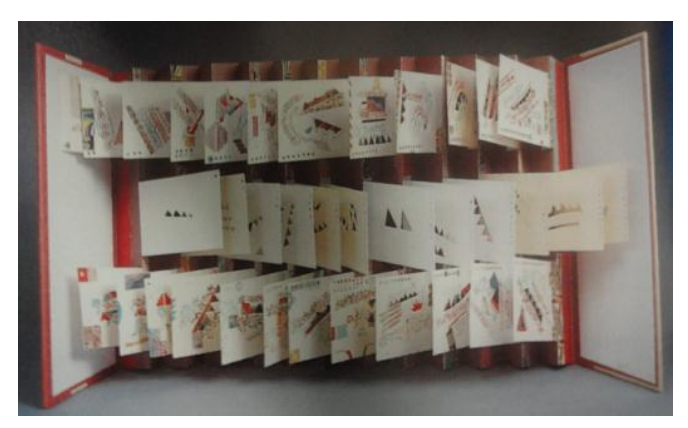

Fonte: BOOK ARTS, 1990, p. 30. 
O fore-edge book já trabalha com a composição artística dos cortes do livro, onde os mesmos possuem aparência dourada com o livro fechado e em repouso, mas que ao movimento lequeado de suas laterais revelam as pinturas ali escondidas.

Figura 22 - Fore-edge book



Fonte: PAIVA, 2010, p. 89.

No Brasil, a participação de pintores renomados na composição artística dos livros, tanto nas encadernações quanto nas ilustrações, ocorre principalmente na década de 1920. Knychala (1991) mostra que, pouco antes desse período, começam a assinar seus trabalhos Di Cavalcanti e Cícero Dias, que primeiramente fazem desenhos no estilo art nouveu, mas que posteriormente participam ativamente da Semana de Arte Moderna em 1922. Outros artistas modernistas que também trabalharam como ilustradores foram Tarsila do Amaral, Anita Malfatti e Victor Brecheret, além dos escritores Menotti Del Picchia e Monteiro Lobato, que ilustraram alguns de seus próprios livros. Contudo, os livros de artistas na concepção de produção artesanal surgiram nas confrarias ou sociedades que produziam livros, com destaque para a Confraria dos Cem Bibliófilos do Brasil, que, como aponta Barrios (2008), teve inspiração nas primeiras sociedades de bibliófilos londrinas, que, por meio da tiragem reduzida, podiam controlar a qualidade da edição.

Segundo Barrios (2008), a Sociedade dos Cem Bibliófilos do Brasil surge em 1943 pela iniciativa do empresário e amante de livros Raimundo de Castro Maya, 
com o objetivo de publicar 120 exemplares com alta qualidade de impressão, publicando ao todo 23 títulos.

Figura 23 - Gravura de Darel (Cem Bibliófilos do Brasil)

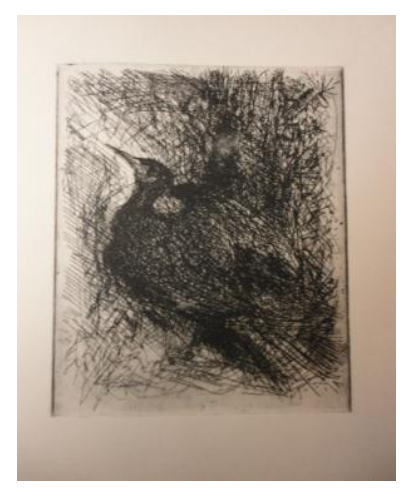

Fonte: RODRIGUES, 1961, p. 6.

Os textos usados pela Sociedade do Cem Bibliófilos do Brasil, conforme Barrios (2008), são de autores brasileiros consagrados, como Machado de Assis, Manuel Bandeira, Jorge Amado, Manuel Antônio de Almeida e Aníbal Machado, entre outros grandes escritores. Todos os volumes, além da cuidadosa composição gráfica, com a escolha minuciosa do papel e do tipo, também eram ilustrados por grandes artistas brasileiros, entre eles Portinari, Di Cavalcanti, Darel, Enrico Bianco, Marcello Grassmann, Babinski, Lívio Abramo, Aldemir Martins e outros, que adotavam principalmente as gravuras em madeira e metal como método de criação e reprodução das suas obras nestes livros, que também tiveram obras em serigrafia e litografia. A Sociedade contou com ilustres participantes:

Faziam parte da comissão executiva da sociedade D. Pedro de Orleans e Bragança, Raimundo Ottoni de Castro Maya, Afrânio Peixoto, Cypriano Amoroso Costa e Max Fisher. A sociedade contava entre os seus sócios com Carlos Lacerda, José E. Mindlin, Ricardo Xavier da Silveira, Ernesto Wolf, Pedro da Silva Nava, Walter Moreira Salles, Gilberto Chateaubriand, Carlos Guinle, Francisco Matarazzo Sobrinho, Celso Lafer, Yolanda Penteado Matarazzo, Roberto Marinho, Israel Klabin entre outros. (BARRIOS, 2008, p. 788)

Outras iniciativas de Associação em torno da produção de livros foram feitas, como a Cattleya Alba: Confraria dos Bibliófilos Brasileiros, iniciada em 1945, e as Edições Condé, que também começam sua produção em 1945. 
Knychala (1983) também dá notícias de inúmeras outras edições de livros de arte, como as da Philobiblion, produzidas por Manuel Segalá; Edições Hipocampo, dos poetas Tiago de Melo e Geir Campos; O Gráfico Amador, fundada por Gastão de Holanda, Aloísio Magalhães, Orlando da Costa Ferreira e Sebastião Uchoa Leite, com participação de Ariano Suassuna; Edições Dinamene, realizadas em Salvador por Pedro Moacir Maia; Edições Alumbramento; e também A Confraria dos Amigos do Livro, idealizada por Carlos Lacerda; todas com produção artesanal, primando pela qualidade tipográfica, com tiragem reduzida e ilustrações de renomados artistas.

Uma iniciativa que produz livros de arte ainda hoje é a Confraria dos Bibliófilos do Brasil, fundada por José Salles Neto, que tem como primeira produção O quinze, de Rachel de Queiróz, produzido em 1995, com tiragem reduzida de 250 exemplares, ilustrado por Abraão Batista.

\subsection{O estudo da segurança contra roubo e furto de livros raros na Ciência da Informação}

Um dos problemas em se definir e/ou delimitar a Ciência da Informação (Cl) está na dificuldade de apontar o seu objeto de estudo: a informação. Para Wersig e Neveling (1975), existem seis abordagens para o uso e significado de informação:

1) Abordagem estrutural (orientada para a matéria): as estruturas do mundo - quer possam ser apreendidas ou não -, constituem "informação".

2) Abordagem do conhecimento: o conhecimento elaborado à base da percepção das estruturas do mundo é "informação"; depende da apreensão da informação pelo indivíduo.

3) Abordagem da mensagem: "informação" é frequentemente usada como sinônimo de "mensagem" (ou seja, refere-se a como o conteúdo da informação é medido pela mensagem). 
4) Abordagem do significado (característica da abordagem orientada para a mensagem): aceita somente o significado da mensagem como "informação".

5) Abordagem do efeito (orientada para o receptor): a "informação" somente ocorre como um efeito específico de um processo específico ou não específico.

6) Abordagem do processo: "informação" não é um dos componentes do processo, mas o próprio processo.

Essas abordagens estão presentes nos paradigmas da $\mathrm{Cl}$ propostos por Capurro (2003), principalmente nos paradigmas físico e cognitivo. No primeiro, a informação está nos objetos físicos e, no segundo, a apreensão da informação depende das necessidades de informação dos indivíduos, mudando ou não seu estado de conhecimento. Contudo, nessas abordagens não se vê muitos elementos que os integram ao paradigma social, pois não está presente a preocupação de entender o usuário dentro de um contexto social capaz de influenciar suas necessidades de informação, em parte porque esta visão foi consolidada após a publicação do artigo de Wersig e Neveling (1975).

Buckland (1991) trabalha com três conceitos de informação, que convergem com as abordagens descritas anteriormente:

1) Informação-como-processo: informação entendida como o ato de informar, de comunicar o conhecimento transformando o receptor.

2) Informação-como-conhecimento: o conhecimento é usado para minimizar as incertezas.

3) Informação-como-coisa: a informação está presente no conhecimento comunicado, ou seja, nos objetos, nos documentos.

As perspectivas apresentadas sobre o conceito de informação mostram sua ambiguidade e tentam defini-lo com termos tão ambíguos quanto a própria informação, como no caso do uso do "conhecimento, mensagem e significado" como sinônimos de informação. 
Diante dessas múltiplas e incertas definições e usos do termo informação, Capurro e Hjørland (2007) decidem fazer uma regressão às origens do termo, a fim de encontrar algo que possa defini-lo com maior exatidão. Chegam à conclusão de que não é possível, por meio do levantamento histórico, chegar a um conceito unívoco, mostrando que o termo não dever ser visto isoladamente, mas em comparação com outros termos, como documento e mídia. Eles também são contra o uso assertivo do termo informação e dizem que a sua distinção mais importante está entre informação-como-coisa ou como signo, passível de interpretação de um agente cognitivo.

A Cl desenvolveu-se a partir da recuperação da informação. Portanto, a informação consolidada em determinado objeto ou coisa como Buckland (1991) demonstra, só é passível de recuperação em sua totalidade se recuperado o objeto. O roubo ou furto de um livro raro presente em uma biblioteca, onde está tratada e organizada para sua recuperação e acesso público, restringiria o acesso à informação presente neste livro ao domínio de seus raptores.

A representação da informação presente em um livro raro pode ser usada como ferramenta de segurança. A análise bibliológica que visa a descrever todas as características intrínsecas e extrínsecas à produção de um livro raro permite individualizá-lo, servindo como uma representação do objeto que permite identificálo em caso de roubo e furto, também, como método de recuperação da informação presente neste objeto, como mostram Rodrigues, Calheiros e Costa (2007). O mesmo ocorre com a fotobibliografia, ou didascálica - como também é chamada -, que visa a copiar a folha de rosto do livro, com a adição de duas barras indicando a quebra de linha, de modo que esta representação da informação contida na folha de rosto de um livro raro permite um primeiro controle de obras ainda não catalogadas (Pinheiro, 2007). Portanto, além de tornar a obra passível de recuperação, a didascálica serve como agente de segurança, ao ser um documento da existência daquela obra na instituição.

A segurança contra roubo ou furto de livros raros está inserida no contexto da $\mathrm{Cl}$ principalmente no seu paradigma físico, no qual esse é representante da definição de informação-como-coisa, e as técnicas de segurança tentam permitir que 
se continue a recuperação dessa informação. No entanto, o livro raro também pode se enquadrar na definição de informação-como-processo, já que é parte de um processo comunicacional, assim como no contexto da informação-comoconhecimento, pois pode preencher as lacunas de conhecimento de um indivíduo e, com isso, "diminuir suas incertezas", citando a expressão de Shannon e Weaver (1949).

Diante das múltiplas definições de $\mathrm{Cl}$ e de informação, a segurança contra roubo e furto do livro raro, que é entendido não só como suporte de informação, mas, também, como objeto informacional, ou informação-como-coisa, enquadra-se principalmente no paradigma físico da $\mathrm{Cl}$, pois o roubo de um exemplar impede que esta obra esteja disponível para consulta detalhada de suas características físicas, como pigmentação de tintas, filigranas, textura dos materiais usados na confecção da encadernação ou do papel, entre outras, que não podem ser recuperadas por meio de cópias digitais do livro, acarretando em perda de informação.

A noção de livro raro como documento permite que este seja objeto de estudo dos paradigmas cognitivo e social, quando considerado como informação-comoprocesso e informação-como-conhecimento; ou seja, quando o livro raro se torna parte das necessidades de informação dos usuários motivados por desejo próprio ou pelas relações sociais nas quais está inserido, que buscam a informação presente no "objeto" livro raro.

\subsection{Livros raros e memória}

Para Halbwachs (2006) existem dois tipos de memória: a individual e a coletiva. O autor mostra que a memória individual está condicionada à memória coletiva, pois apesar de ser uma memória interna ao indivíduo, ela se apoia muitas vezes em elementos externos, como objetos, lugares ou mesmo na memória de outras pessoas, para a completude de sua lembrança; ou seja, esta memória individual ou autobiográfica se apoia na memória coletiva, externa ou histórica, pois o indivíduo está inserido numa sociedade onde a vida particular faz parte de uma história maior. 
Le Goff (2013) diz que a memória coletiva se manifesta em dois materiais: os documentos e os monumentos. $\mathrm{O}$ autor mostra que esta divisão em seus primórdios trata o monumento como sendo um sinal do passado que se liga ao poder de perpetuação das sociedades históricas, seja de forma voluntária ou involuntária. O monumento, a partir da Antiguidade romana, especializar-se-ia em dois sentidos: o primeiro enquanto obra comemorativa da arquitetura ou escultura como, por exemplo, os troféus; e o segundo como monumento funerário. $O$ documento, neste contexto, segundo o autor, teria sua denominação ligada à prova histórica e se afirmaria essencialmente como testemunho escrito. No entanto, Le Goff (2013) defende que se deve encaminhar esta visão para a idiossincrasia entre os termos, de modo a serem vistos como documento/monumento; ou seja, o documento é monumento porque ele:

\begin{abstract}
É, antes de mais nada, o resultado de uma montagem, consciente e inconsciente, da história da época, da sociedade que o produziram (sic), mas também das épocas sucessivas durante as quais continuou a viver, talvez esquecido, durante as quais continuou a ser manipulado, ainda que pelo silêncio. (LE GOFF, 2003, p. 496-497).
\end{abstract}

Os livros impressos associam-se como documentos/monumentos da memória coletiva e também como elementos externos de uma memória individual em diversos aspectos. Manguel (2006a), por exemplo, mostra como as bibliotecas particulares se tornam o espelho de seus proprietários, pois a seleção de títulos e as associações feitas nesta seleção, onde um livro se conecta a outro, por meio das convicções pessoais e individuais de seu dono, influi inclusive na organização física destas bibliotecas. O autor vai além e põe as bibliotecas como possíveis reflexos de uma identidade social, ao dizer que podemos imaginar bibliotecas com livros que gostaríamos de possuir, para que esta reflita os nossos interesses e fraquezas e que "de modo semelhante, a identidade de uma sociedade ou de uma nação possa ser espelhada por uma biblioteca, por uma reunião de títulos que, em termos práticos ou simbólicos, faça as vezes de definição coletiva" (MANGUEL, 2006a, p. 241).

Tomando o livro em suas características de produção em cada título em cada exemplar, Greenhalgh e Manini (2013), diante da definição de informação-comocoisa proposta por Buckland (1991), defendem que o livro raro é um objeto informacional no todo e não apenas suporte informacional; ou seja, as 
características estéticas, a escolha da matéria-prima, o formato, a tipografia, entre outros elementos usados em um livro refletem a memória individual daquele que exerce a profissão de encadernador, impressor, ou outro ofício ligado à impressão de livros, que cria um estilo próprio e que também reflete as características presentes na memória coletiva da sociedade em que este indivíduo está inserido.

Todas as características mencionadas ajudam a situar o livro, pela
informação visual, dentro do que Halbwachs (2006) chama memória coletiva
e individual, pois é possível observar a identidade de uma nação nos estilos
de produção do livro (encadernações, tipografia, entre outros),
demonstrando características políticas, sociais, culturais e artísticas de um
povo ou ainda relacionar à memória individual daqueles que o produziram,
através das características que relacionam o objeto ao modo de pensar de
uma pessoa, que está relacionada a vários grupos, legitimando esse
pensamento individual dentro de uma memória coletiva, isso por meio dos
Ex libris, impressores, tipógrafos, encadernadores e artistas do livro, que
contribuíram individualmente criando e aperfeiçoando técnicas tipográficas,
que refletiam os costumes e pensamentos do espaço/tempo que estavam
vivenciando, repassando essas percepções às gerações futuras
(Greenhalgh; Manini, 2011, p. 3).

Apesar do livro impresso geralmente apresentar mais de um exemplar, no caso de livro raro é possível até mesmo que os exemplares sejam diferentes entre si. Como visto em tópicos anteriores, aos exemplares podem ser adicionadas características posteriores à sua produção, como é o caso, por exemplo, de um Ex libris. Inclusive as encadernações podem ter sido incluídas bem depois à impressão do conteúdo, pois era comum vender os livros sem encadernação, para que a mesma fosse escolhida pelos seus futuros proprietários, como mostra Moraes (1965/2005). O autor diz ainda que foi moda entre os bibliófilos até o século XIX encadernarem todos os livros de sua biblioteca com um único estilo de encadernação.

Araújo (2008) mostra que os exemplares se diferenciam não somente pelas adições posteriores à sua impressão, mas também por seus erros, que chegavam a atingir um terço dos livros publicados no século XVIII, por exemplo. Estes erros nem sempre eram corrigidos em todos os exemplares, fazendo que houvesse variações dentro de uma mesma tiragem. Assim como também geravam variações, às vezes, em que era necessário substituir um tipo móvel, seja por sua quebra ou desgaste, gerando novo efeito de impressão nos exemplares seguintes. Um exemplo desta redução de exemplares com determinada característica dentro de uma mesma 
tiragem é vista em Moraes (1965/2005) ao mostrar que a primeira edição da Chronica do felicíssimo rei dom Emanuel, impressa em Lisboa em 1556, onde há críticas a grandes personalidades da época, foi recolhida para o cancelamento de várias folhas restando hoje apenas três ou quatros exemplares conhecidos, sem mutilação.

Não apenas as bibliotecas enquanto conjunto bibliográfico, mas também os exemplares um a um, carregam consigo a memória individual e coletiva, presente no seu conteúdo, como é o propósito informacional do livro, mas também nas técnicas de produção, nas escolhas estéticas, nas matérias-primas utilizadas, entre outros aspectos. Portanto, o roubo ou furto de uma obra pode ocasionar a perda permanente de informação para a memória coletiva de uma sociedade ou nação.

\subsection{0 valor financeiro dos livros}

O livro é mais que mero suporte de informação, sendo considerado e apreciado em alguns casos como objeto de arte, com características históricas de produção, que traz em si parte da trajetória das civilizações e tem a capacidade de modificar o pensamento humano. É evidente que obras consideradas marcantes para a humanidade teriam valor de mercado condizente com sua grandeza na sociedade ou no mundo. O livro tornou-se um quadro, um artefato de investimento, pois a tendência é que cada vez mais se torne escasso, mais antigo e, por consequência, mais valioso. Portanto, os livros começaram a atingir valores cada vez maiores e exorbitantes nas casas de leilões, existindo sempre pessoas dispostas a pagar fortunas por estas relíquias.

Os livros dos grandes cientistas que influenciaram o modo de pensamento atual do ocidente alcançam, em leilões, valores consideráveis, como no caso do livro De revolutionibus orbium colestium (Sobre a revolução dos corpos celestes), de Nicolau Copérnico, que arrecadou em leilão organizado pela Christie's, em 2008, US\$ 2,2 milhões. Neste se encontra a afirmação pioneira de que o Sol - e não a Terra - está no centro do Sistema Solar. Nesta mesma ocasião ainda foram leiloados os livros $A$ arte de navegar, de Pedro de Medina, considerado o primeiro 
manual prático de navegação, vendido por US $\$ 578$ mil; Le operazioni del compasso geometrico, et militare, de Galileu Galilei, que alcançou US\$ 506 mil; Harmonices mundi libri $V$, de Johannes Kepler, comprado por US\$ 362 mil; e as 130 separatas do cientista Albert Einstein, que custaram US\$ 314 mil, como noticiado por Marcolin (2008).

Bartlett (2013) indica os valores dos livros na Feira de Livreiros Antiquários de Nova York de 2005, onde a primeira edição italiana do Pinóquio era vendida a US\$ 80 mil. A autora ainda cita a primeira edição de $O$ conto de Peter Rabbit colocado à venda por US\$ 15 mil, valor justificado pela baixa tiragem de 250 exemplares, custeada pela própria autora, Beatrix Potter. Na feira, a primeira edição de Gato na cartola era anunciada por US\$ $\$, 5$ mil, enquanto um exemplar autografado de $A$ estrutura molecular dos ácidos nucleicos, que contém o primeiro e o segundo artigos escritos por Watson e Crick sobre o DNA, estava à venda por US\$140 mil, e a primeira edição de Harry Potter e a pedra filosofal, da qual foram impressas apenas quinhentas cópias, valia US\$30 mil.

No site da casa de leilões Christie's ${ }^{21}$ é possível ver uma relação de outros livros, além dos já citados, que alcançaram o maior valor de venda dentro da categoria em que se encaixa. O primeiro livro impresso no mundo, a Bíblia de Gutenberg, alcançou em leilão realizado no Rockefeller Center, em Nova lorque, em 1987, o valor aproximado de US\$ 5 milhões, considerado um recorde para uma bíblia. O livro The Rothschild prayerbook, produzido por volta de 1505, é considerado o mais caro manuscrito iluminado já vendido, arrematado em janeiro de 2014 por US\$13,6 milhões, enquanto o livro de medicina que conseguiu maior oferta em leilão foi De Humani Corporis Fabrica libri septem, escrito por Andreas Vesalius em 1543, vendido a US\$1,6 milhão. O livro infantil mais valioso custou US\$ 1,5 milhão, sendo um exemplar de Alice no país das maravilhas, de Lewis Carrol. O livro mais caro já vendido foi o manuscrito de Leonardo da Vinci chamado Códice de Leicester, vendido pela Christie's em 1994 por US\$30,8 milhões.

${ }^{21}$ Site da Casa de Leilão Christies: <http://www.christies.com>. Acesso em: 05 ago. 2014. 
Em outra grande casa de leilões, a Sotheby's ${ }^{22}$, foi vendido o livro impresso mais caro, o The Birds of America, arrematado em dezembro de 2010 por US $\$ 11,5$ milhões, e o The Bay Psalm Book, vendido em novembro de 2013 por aproximadamente US\$14 milhões.

\subsection{Roubos e furtos de bens culturais}

Bens culturais, como telas, esculturas, louças, vasos, indumentárias, peças religiosas, livros, documentos e todo tipo de artefatos arqueológicos sempre atingiram valores venais elevados, o que representa a importância que é dada a estes objetos dentro da cultura em que estão inseridos, seja pelo material de fabricação, pela escassez, simbologia, ou outro atributo que o diferencie e o valorize dentro da sociedade. Devido a este potencial mercadológico, estes itens sempre foram alvo de investida de criminosos, que, pelo roubo, buscam lucrar com a venda destes bens. Como guardiões de boa parte deste patrimônio cultural, os museus, arquivos e bibliotecas do mundo inteiro são frequentemente invadidos para a subtração destas peças, sendo que, muitas vezes, estas obras nunca mais são recuperadas, incorrendo em perda patrimonial e cultural não só para a instituição, mas para toda a humanidade, que tem parte de sua história perdida.

Um dos quadros mais famosos do mundo, A Monalisa, de Leonardo da Vinci, pintada em 1503, foi levada do Museu do Louvre em 21 de agosto de 1911 por um pintor de paredes chamado Vincenzo Peruggia. Ele justificou o roubo como patriotismo, pois para ele a obra deveria retornar à Itália. A partir deste incidente, a obra passou a ser vigiada constantemente (LACAYO, 2009; CUMMING, 2011). Em 22 de agosto de 2004 foi roubado do Museu Munch, em Oslo, outro quadro muito famoso: O grito, de Edvard Munch. Houve rendição, à mão armada, de um segurança, e as obras - também foi roubado o quadro Madonna, do mesmo artista foram retiradas das paredes da primeira sala, a mais próxima da saída, sem que qualquer alarme disparasse. $O$ artista havia pintado alguns exemplares sobre cartão

\footnotetext{
${ }^{22}$ Site da Casa de Leilão Sotheby's: <http://www.sothebys.com/en/departments/booksmanuscripts.html >. Acesso em: 13 jun. 2014.
} 
desta obra e outro exemplar já havia sido roubado dez anos antes, tendo, contudo, sido recuperado posteriormente. Após dois anos, em 31 de agosto de 2006, os dois quadros, avaliados em aproximadamente US\$ 110 milhões, foram recuperados (STOLEN MUNCH..., 2006); um ano antes haviam sido presos três suspeitos que receberam condenações de quatro a oito anos de prisão. Os quadros sofreram alguns danos neste período em que estiveram desaparecidos, como queimaduras de cigarro, passando, portanto, por um processo de restauração que durou cerca de um ano, para finalmente voltarem a ser expostos ao público em março de 2008 (APÓS ROUBO..., 2008).

Inúmeros roubos já foram realizados na brevidade do século XXI. Alguns casos estão listados abaixo, mas isso não tem por objetivo elencar todos os delitos cometidos neste período, menos ainda estabelecer a relação dos maiores acontecimentos desta natureza, seja por valor, engenhosidade ou qualquer outro critério, mas demonstrar que são muitas as investidas contra o patrimônio cultural e que, apesar de muitas obras terem sido encontradas, algumas nunca mais foram recuperadas, tornando-se uma perda irreparável para a sociedade, tanto sob o aspecto financeiro, quanto cultural e histórico.

2001 - Em junho foi furtado do Museu Judaico em Nova lorque o quadro Estudo sobre Vitebsk do pintor Marc Chagall. Provavelmente a motivação do roubo foi política, pois o Museu recebeu uma carta de autoria da "Comissão Internacional para a Arte e Paz" dizendo que a obra seria devolvida apenas quando houvesse paz entre os palestinos e os judeus (ELLISON, 2001; QUADRO É..., 2001). A obra, produzida em 1914, foi furtada durante um coquetel realizado no local e está avaliada em aproximadamente US\$ 1 milhão; foi encontrada em janeiro de $2002 \mathrm{em}$ um depósito dos correios do estado do Kansas (QUADRO DE CHAGALL..., 2002).

2002 - No mês de dezembro foram furtadas as obras Vista da Praia de Scheveningen com Tempestade (1882) e Igreja Protestante de Neunen (1884), de Van Gogh, do Museu que leva seu nome, em Amsterdã (TWO VAN GOGH..., 2002). Os ladrões invadiram o local pelo telhado; foram presos e condenados, em 2004, a quatro anos e meio de reclusão. Contudo, as obras, estimadas em 
aproximadamente $£ 1,8$ milhão, ainda não foram recuperadas (CONDENADOS HOMENS..., 2004).

2003 - Dois crimes se destacaram. O primeiro ocorreu na Escócia, onde foi levada do Castelo de Drumlanrig a obra $A$ virgem de fuso, de Leonardo da Vinci, avaliada em cerca de US\$ 60 milhões. Dois homens se passaram por visitantes e imobilizaram uma empregada do local para poder roubar o quadro, que foi recuperado em 2007 (TELA DE DA VINCI..., 2007; CARRELL, 2010). O segundo ocorreu na Áustria, onde foi subtraído o Saleiro de ouro do Museu de Arte de Viena, artefato produzido pelo artista Benvenuto Cellini. O ladrão escalou um andaime e quebrou uma janela e a vitrine para se apoderar do objeto, que só foi recuperado em 2006, ocasionando a prisão de um suspeito (ESCULTURA DE OURO..., 2003; HARDING, 2006).

2004 - Além do já mencionado desaparecimento do quadro $O$ grito, de Edvard Munch, também ocorreu o furto da obra Nature morte a la charlotte, de Pablo Picasso, que estava no Centre Pompidou, em Paris. O crime foi descoberto após um inventário em que se verificou a falta da pintura. A obra é datada de 1924 e avaliada em aproximadamente 2,5 milhões de euros. Foi encontrada em 2005 (POLíCIA FRANCESA..., 2005; QUADRO DE PICASSO..., 2005).

2005 - No Museu Nacional de Belas Artes do Chile, no mês de junho, foi furtada a escultura $O$ torso de Adele, de Auguste Rodin. A peça, avaliada em aproximadamente US\$500 mil, foi devolvida no outro dia por um estudante que alegou tê-la encontrado no Parque Florestal de Santiago. Posteriormente, o mesmo rapaz viria a confessar a autoria do crime (ESCULTURA DE RODIN..., 2005; UNIVERSITÁRIO CONFESSA..., 2005).

2006 - No mês de novembro, a obra Los niños del carretón, de Francisco de Goya, pertencente ao Museu de Arte de Toledo, em Ohio, nos Estados Unidos, foi furtada do caminhão que a transportava para Nova lorque. A transportadora informou que 0 quadro foi deixado por toda a noite dentro do veículo na porta do hotel onde os transportadores descansavam. Alguns dias após o furto, a obra foi encontrada mediante a denúncia de um homem por telefone que o FBI havia criado para obter 
notícias deste evento. A obra possuía seguro em US\$1,1 milhão (EL FBI..., 2006; QUADRO DE GOYA..., 2006).

2007 - Quatro ou cinco homens armados e encapuzados invadiram o Museu de Belas Artes Jules Chéret, em agosto, e levaram as obras Falaises prés de Dieppe, pintada por Monet; Allee de peupliers de Moret, de Sisley; além dos Allegorie de l'eau e Allegorie de la terre, de Jan Brueghel. Dois destes quadros já haviam sido roubados em 1998 (KIMBELL, 2007). As obras foram recuperadas em 2008; o suspeito foi preso na Flórida - Estados Unidos (TABLEAUX VOLÉS..., 2008).

2008 - Os quadros Campo de papoulas perto de Vétheuil, de Claude Monet; Conde Lepic e suas Filhas, de Edgar Degas; Branches de marronnier en fleur, de Vincent Van Gogh; e Rapaz de colete vermelho, de Paul Cézanne, foram roubados, por homens armados, da Fundação Emil Buehrle (Suíça). Os quadros de Monet e Van Gogh foram encontrados em 2008 e o de Cézanne em 2012 (QUADRO DE CÉZANNE..., 2012). Menos de uma semana antes deste incidente, também na Suíça, no Centro Cultural Pfäffikon, foram levadas as pinturas a óleo Tête de cheval e Verre et Pichet, de autoria do pintor Pablo Picasso. As mesmas tinham sido emprestadas para a exposição pelo Museu Sprengel, de Hannover, na Alemanha. As obras de Picasso foram recuperadas em Belgrado, a partir de uma ação conjunta das polícias da Suíça e da Sérvia, em outubro de 2011 (TWO STOLEN..., 2011). Outro grande furto aconteceu no Museu de Gelsenkirchen, na Alemanha, onde foram levadas as obras: a aquarela Retrato de mulher, de Nolde, a gravura Kopf Dr. Pauli, de Ernst Ludwig Kirchner, e a litografia Vier akte auf einer waldlichtung, de Otto Müller. O ladrão fugiu por uma sala contígua ao salão de exposição, pois a porta entre os cômodos estava aberta devido a um evento ocorrido no Museu. O rapto aconteceu provavelmente na troca de turnos da equipe de segurança (TRÊS QUADROS..., 2008).

2009 - No Museu Scheringa do Realismo, na Holanda, homens armados e mascarados apontaram suas armas para a segurança, para os funcionários do Museu e para os visitantes com o intuito de levar o quadro Adolescência, do espanhol Salvador Dalí, e a tela $A$ música, da pintora polonesa Tamara de Lempicka (ITZKOFF, 2009). Também foi subtraído neste mesmo ano, em Paris, do Museu 
Picasso, um caderno com rascunhos de desenhos do pintor que the dá o nome, sendo a peça avaliada em aproximadamente 8 milhões de euros (CADERNO..., 2009). Em outro evento, no Museu René Magritte, em Bruxelas, dois bandidos com os rostos descobertos, um deles armado, renderam seguranças e escalaram a parede de vidro de proteção para levar a obra Ollympia, do artista que dá nome ao museu (QUADRO DE RENÉ..., 2009). No Museu Cantini, em Marselha, o quadro conhecido como Les choristes ou Les figurants, do francês Edgar Degas, também foi levado sem qualquer sinal de arrombamento. A obra havia sido emprestada ao Cantini pelo Museu D`Orsay, de Paris (UN TABLEAU..., 2009).

2010 - A obra Flores de papoula, de Van Gogh, foi furtada do Museu Mohamed Mahmoud Khalil, no Cairo. A pintura foi retirada de sua moldura pouco após a abertura do Museu (QUADRO DE VAN GOGH..., 2010). Em outubro, o governo do Egito condenou 11 funcionários do Ministério da Cultura, incluindo o vice-ministro, a três anos de prisão por negligência na segurança do patrimônio cultural do país (EGITO CONDENA..., 2010). No Museu de Arte Moderna de Paris foram furtados cinco quadros com valor aproximado de $£ 500$ milhões: Le pigeon aux petits pois, de Pablo Picasso; La pastorale, de Henri Matisse; L'olivier près de l'estaque, de Georges Braque; La femme à l'éventail, de Amedeo Modigliani; e Nature morte aux chandeliers, de Fernand Léger. Os ladrões conseguiram entrar no Museu arrombando o portão e quebrando uma das janelas (DAVIES; JONES, 2010).

2011 - Durante a revolta que culminou com a queda do ditador Hosni Mubarak, o governo do Egito anunciou o sumiço de oito peças do Museu do Cairo. Entre elas, uma estátua de madeira coberta com ouro que pertenceu ao rei da XVIII dinastia Tutankamon e peças do período Armana, como a cabeça de uma princesa em arenito e uma estátua em pedra calcária de Aquenáton segurando uma mesa de oferendas (OBJETOS VALIOSOS..., 2011). Sete obras de arte foram furtadas do Museu do Palácio Imperial na China. O museu está localizado dentro da cidade proibida e o ladrão conseguiu entrar abrindo um buraco em um dos muros (BRISTOW, 2011).

2012 - No dia 17 de fevereiro, dois ladrões encapuzados invadiram e renderam a única guarda na segurança do Museu Arqueológico de Olímpia, na Grécia. Os 
ladrões levaram entre sessenta e setenta objetos de bronze e cerâmica da coleção histórica dos jogos olímpicos da antiguidade. Em novembro, três pessoas foram presas e muitas peças recuperadas (POLíCIA RECUPERA..., 2012). O Museu Kunsthal de Roterdã, na Holanda, teve sete obras subtraídas no dia 16 de outubro. Os ladrões invadiram e levaram as obras em grandes bolsas. Entre as obras levadas estavam as telas Cabeça de arlequim, de Pablo Picasso, e A leitura da menina em branco e amarelo, de Henri Matisse (CARVAJAL, 2012). Em 14 de julho de 2014, quatro criminosos foram condenados a ressarcir o museu em 18 milhões de euros, pelas sete obras que não foram recuperadas (LOS AUTORES DEL ROBO..., 2014).

2013 - No dia 28 de maio, o Museu de História de Buffalo, nos Estados Unidos, teve um voluntário acusado de furtar e tentar comercializar cartas e cartões postais da coleção Goodyear pertencente ao museu (FAIRBANKS, 2013).

2014 - Em fevereiro deste ano, um colecionador entrou em contato com o Museu Nacional de Belas Artes de Havana em Cuba, para perguntar se uma obra, Carnaval infantil, do vanguardista Eduardo Abela, que havia adquirido pertencia àquela instituição como mostra Primera (2014). A autora relata que a instituição pesquisou e posteriormente confirmou ser sua a obra. $O$ colecionador retornou à galeria que havia comprado o quadro e foi apresentado a dez Romañach, que haviam sido mutilados por faca ao tirar da moldura. Estas obras também pertenciam ao Museu Nacional de Havana (PRIMERA, 2014).

Os exemplos acima dão uma amostra da ameaça à que os bens culturais de qualquer natureza estão expostos. Ainda mostram que, apesar da recuperação de alguns itens, outros ainda não foram recuperados e que alguns objetos que retornaram à instituição de origem sofreram avarias durante o período em que estiveram sob o domínio dos ladrões. Várias foram as técnicas utilizadas pelos criminosos para ter acesso ao objeto roubado, seja o uso de armas, de máscaras para esconder sua identidade, invasão com arrombamento ou mesmo o privilégio de informação sobre a posição das obras e sobre o sistema de segurança. Pois, alguns bens foram levados sem chamar a atenção da vigilância e, muitas vezes, sem deixar rastros de que houve qualquer tipo de arrombamento, permitindo que fossem levantadas suspeitas sobre o envolvimento de funcionários nos crimes. 


\subsubsection{Roubos e furtos de bens culturais no Brasil}

O Brasil também sofre com as investidas de ladrões neste tipo de acervo. Vários são os casos de roubos e furtos às instituições de salvaguarda de bens culturais. Três grandes subtrações marcaram o Brasil entre os anos de 2006 e 2008, quando foram roubadas obras do Museu de Arte de São Paulo (MASP), do Museu Chácara do Céu, no Rio de Janeiro, e da Pinacoteca de São Paulo.

As obras A dança, de Pablo Picasso; Marine, de Claude Monet; Dois balcões, de Salvador Dali; e Jardim de Luxemburgo, de Henri Matisse; além do livro Toros, também de Picasso, foram levadas do Museu Raimundo Ottoni de Castro Maya, também conhecido como Museu Chácara do Céu. Localizado no bairro de Santa Teresa, na cidade do Rio de Janeiro, no dia 24 de Fevereiro de 2006, foi invadido por quatro assaltantes armados. Os ladrões forçaram o vigia a desligar o sistema de segurança e ameaçaram explodir uma granada se alguém se aproximasse (BRASIL, 2006).

No dia 20 de dezembro de 2007, foram retirados do MASP os quadros $O$ lavrador de café, de Cândido Portinari; e Retrato de Suzanne Bloch, de Pablo Picasso, avaliados em aproximadamente $\mathrm{R} \$ 100$ milhões. Os bandidos arrombaram a porta do Museu com um macaco hidráulico e foram direto às obras; a ação durou cerca de três minutos e, apesar de ter sido registrada por câmeras, o Museu não possuía alarme, sensores e seguro das obras (POLÍCIA SUSPEITA..., 2007; ROUBO NO MASP..., 2007). As telas foram encontradas no dia 08 de janeiro de 2008 em uma casa localizada em Ferraz de Vasconcelos, na Grande São Paulo, onde foram presos dois suspeitos de participação no crime (TAVARES; PEREIRA; GODOY, 2008). No dia 04 de fevereiro de 2009, quatro pessoas foram condenadas pela participação no crime, com penas de reclusão variando de 3 anos e 30 dias a 9 anos e 6 meses. Em outubro de 2009, o Superior Tribunal de Justiça (STJ) anulou a decisão tomada pelo Tribunal de Justiça de São Paulo, alegando que a competência pelo caso é federal e não estadual (STJ DERRUBA..., 2009).

A Estação Pinacoteca, na cidade de São Paulo, foi assaltada em 12 de junho de 2008, quando foram levadas as obras Mulheres na janela, de Di Cavalcanti; $O$ 
pintor e seu modelo e Minotauro, bebedor e mulheres, gravuras de Pablo Picasso; e Casal, um guache sobre cartão de Lasar Segall. Os criminosos passaram por visitantes e a ação foi filmada por câmeras de segurança (LADRÕES LEVAM..., 2008). As obras foram recuperadas e voltaram a ser expostas em agosto de 2008 (MAIA JUNIOR, 2008).

Em 02 de abril de 2013 foi furtada do Museu da República uma caneta de ouro que o ex-presidente Afonso Pena ganhou do exército (CANETA QUE PERTENCEU..., 2013). O furto ocorreu entre $15 \mathrm{~h} 45$ e $16 \mathrm{~h}$, quando um visitante ficou sozinho na sala onde estava a caneta de ouro, pois o guarda que o acompanhava teve que recepcionar um outro grupo que também visitava o museu (ROUBO NO MUSEU DA REPÚBLICA..., 2013).

No portal do Iphan existe uma base de dados sobre bens culturais desaparecidos e recuperados. Uma pesquisa nesta base mostra que atualmente 1.596 itens estão desparecidos, enquanto apenas 127 objetos foram resgatados ${ }^{23}$. Estes dados mostram que o Brasil é afetado consideravelmente pelo roubo de bens culturais e que a quantidade de objetos recuperados é muito pequena em relação ao montante de objetos desaparecidos.

\subsection{Roubos e furtos de livros raros}

As bibliotecas no mundo todo também são alvo constante de furtos de suas obras. Apesar de serem mais frequentes os furtos às obras de arte, os livros raros, devido aos altos valores venais que atingem, além do seu valor histórico-cultural, também são alvo de roubo ou furto.

Desde a Idade Média, a preocupação com o roubo e furto aos livros é frequente. Naquela época, os exemplares eram acorrentados às estantes, pois os livros eram considerados símbolo de status, intelectualidade e poder econômico. "Ladrões de livros eram uma praga na Idade Média e na Renascença; em 1752, o

\footnotetext{
${ }^{23}$ Informação retirada do Banco de Dados de Consulta a Bens Culturais Procurados do Iphan em 30 jul. 2014.
} 
papa Benedito XIV lançou uma bula segundo a qual os ladrões de livros seriam excomungados" (MANGUEL, 2006b, p. 276).

No século XIX aconteceram vários furtos na França, cometidos por uma única pessoa: um senhor chamado Guglielmo Bruto Icilio Timoleone, mais conhecido como Conde Libri-Carucci della Sommaia, acadêmico muito bem sucedido, agraciado com a cadeira de Matemática na Universidade de Pisa, e professor de Ciências na Universidade de Paris.

Manguel (2006b) mostra que o Conde Libri se tornou grande apreciador de livros, passando então a colecioná-los e, devido ao seu conhecimento sobre os alfarrábios, foi nomeado secretário da comissão que supervisionaria o "catálogo geral e detalhado de todos os manuscritos, em idiomas antigos e modernos, existentes hoje em todas as bibliotecas públicas departamentais". Este cargo the daria passe livre a todas as bibliotecas da França, privilégio este que o mesmo usou para saquear os locais por onde passava.

As notícias são de que o Conde, além de roubar, passou a comercializar as obras. Várias foram as acusações feitas a ele, sendo que algumas foram encobertas por um amigo, além de suas credenciais o colocarem acima de suspeitas. Ele não roubava apenas volumes inteiros, mas também arrancava páginas que depois eram expostas ou vendidas. Saqueou as bibliotecas das cidades de Carpentras, Dijon, Grenoble, Lyon, Montpellier, Orléans, Poitiers e Tours; somente em Auxerre não concretizou o crime, devido ao acompanhamento de um guarda aos seus trabalhos noturnos. Foi condenado a dez anos de prisão e perdeu todos os seus cargos públicos, mas não sem a defesa de várias personalidades, que ficaram com medo de terem seus nomes envolvidos no episódio, devido às compras de obras furtadas que fizeram com Libri, como relata Manguel (2006b).

Em 1976, um antigo aluno da Stanford University foi condenado, pelo furto de livros daquela instituição, avaliados em US $\$ 100$ mil, como mostra Gauz (1994). Outros dois casos também são relatados pela autora: o primeiro mostra a engenhosidade do ladrão, que se tornou amigo de um antigo funcionário da Biblioteca John Crerar, em Chicago, que Ihe concedeu permissão para ficar sozinho 
nos armazéns de livros raros. O bandido aproveitou-se da facilidade e passou a esconder os livros na roupa. Posteriormente os livros eram comercializados com a ajuda de um livreiro contratado. Os 400 impressos e manuscritos foram recuperados em 1985 e o ladrão foi condenado a dois anos de reclusão. O segundo caso mostra o envolvimento de um bibliotecário no roubo de livros raros do Virginia Military Institute. George B. Davis teria roubado livros avaliados em US $\$ 100$ mil, que seriam vendidos por ele e sua esposa na loja de livros raros Cooper fox farm old and rare books, que tinha acabado de se estabelecer em Millbrook.

Gauz (1994) informa alguns crimes cometidos às bibliotecas na década de 1990. A autora mostra alguns casos de furtos às bibliotecas americanas, como no caso da Illinois University, onde três livros raros, avaliados em US $\$ 75$ mil, foram levados por bandidos que quebraram janelas e portas para ter acesso ao local. Também perdeu seus livros a Biblioteca de Zoologia da Harvad University. Dali foram levados alguns trabalhos do Capitão James Cook e de Charles Darwin. Gauz (1994) também cita o caso do livreiro que alertou a California University sobre obras de sua propriedade que thes foram vendidas. Aproximadamente 260 livros foram recuperados por causa dessa denúncia. Gauz (2006) relata brevemente sobre o crime contra mais de 300 instituições de onde o ladrão teria levado mais de 25 mil livros raros, para que passassem a compor sua coleção pessoal. O sujeito, inclusive, teria desenvolvido técnicas de serragem de portas e arrombamento de fechaduras para melhor exercer o crime.

$\mathrm{Na}$ França, um episódio mais recente que o do Conde Libri também foi bastante comentado pelo fato de ter envolvido uma pessoa, que, assim como o Conde, deveria cuidar das obras e não furtá-las. Em 2003, um manuscrito da Biblioteca Nacional da França chegou a ser vendido pela Christie's com todas as autorizações para sua saída do país. Entretanto, o mesmo se encontrava desaparecido desde 2000 (INDICIADO..., 2004). Este episódio fez com que a polícia chegasse a um suspeito da autoria do crime, que, para a surpresa de todos, era o chefe da divisão que abrigava os manuscritos hebraicos na Biblioteca. Apesar de não ser a última instância, o mesmo foi condenado, em 2007, a cumprir uma pena de prisão por 15 meses, além do pagamento de multa no valor de 75 mil euros pelo 
roubo do pacote Hebreu 52, que continha uma escritura sagrada do século XIII com o Pentateuco (os cinco livros da Torá). O conservador confessou os crimes em um primeiro momento, mas posteriormente voltou atrás, alegando que havia permitido um bônus de saída para o livro, como retribuição de favor a um amigo que o ajudou na compra de outro livro (EX-FUNCIONÁRIO..., 2007; AFFAIRE..., 2007).

Em 2005, uma bibliotecária de livros raros da Yale University encontrou uma lâmina no chão do salão de consulta, o que levou os seguranças a observarem a movimentação dos leitores pelas câmeras de segurança, verificando atitude suspeita em um dos usuários. Descobririam tratar-se de um famoso livreiro de Manhattan especializado em mapas. Ao ser interrogado, o homem confessou sua culpa e com ele foram encontrados vários mapas, pertencentes à biblioteca de Yale e também a várias outras, como a Biblioteca Pública de Boston, a Biblioteca da Universidade de Harvard, a Biblioteca Newberry, em Chicago e a British Library (CAMPBELL, 2006; GAUZ, 2005; HONIGSBAUM, 2006).

Um pesquisador foi preso em 2008 por retirar páginas de livros da British Library. Dos 842 livros consultados por ele, em sua maioria sobre as primeiras relações entre a Europa e o Oriente Médio, com o mapeamento de viagens de europeus pela Mesopotâmia, Pérsia e Império Mongol a partir do século XVI, ao menos 150 livros foram mutilados. Durante o inquérito policial, várias páginas dos livros saqueados foram encontradas em sua residência. Após um usuário sugerir que estavam faltando páginas em algumas obras, os bibliotecários analisaram os exemplares e confirmaram sua violação. Posteriormente, procuraram os registros de todas as pessoas que haviam consultado as obras e verificaram também todas as obras que estas pessoas tinham visto na British Library (LAVILLE, 2008).

Em 2013, o diretor da Biblioteca Girolamini, em Nápoles na Itália, foi condenado a sete anos de prisão domiciliar pelo furto de aproximadamente 2.200 livros desta biblioteca. Como o diretor havia sido gravado em câmaras saindo com muitos livros da biblioteca, uma investigação levou a descoberta de mais de mil livros escondidos em Verona. Destes, cerca de duzentos e cinquenta tinham o selo da Biblioteca Girolamini. Outros cinco livros estavam listados para leilão em 
Munique, na Alemanha, e outros 20 apareceram também para leilão na Inglaterra (GAUZ, 2013).

O portal do Rare Books and Manuscripts Section (RBMS) ${ }^{24}$ arrola notícias sobre casos de roubos ou furtos de livros em todo o mundo. As notícias datam de 1987 até o momento atual. No século XXI existem notícias sobre os crimes e seus desdobramentos (recuperação de obras, prisões e condenações) em todos os anos. Abaixo seguem algumas destas notícias:

2001 - Em abril, a Harvard College Library relatou o furto de 46 obras do século XVIII, descoberto por meio de inventário. Os livros, folhetos e periódicos eram sobre a Revolução Francesa e a era Napoleônica. Livreiros e bibliotecas foram avisadas sobre o crime.

2002 - No Dickens House Museum, em Londres, foram furtadas três primeiras edições de A Christmas Carol, no dia 15 de agosto. As obras foram retiradas do armário onde estavam com um cortador de vidro. Na noite entre os dias 20 e 21 de março, ladrões levaram 8 volumes da obra Les liliacées, de Pierre-Joseph Redouté, que estavam na biblioteca da Utrecht University, na Holanda. O responsável pela biblioteca acredita que o crime foi planejado, pois não sentiram falta de qualquer outro título.

2003 - Em abril, o Reference Center for Marxist Studies, em Nova lorque, comunicou o desaparecimento de quarenta pastas de arquivos, que continham fotografias, manuscritos, notas e cartas relacionadas ao historiador marxista Herbert Aptheker. A suspeita é de que o material tenha sido furtado em janeiro por um usuário do Centro. O Hatefutsoth Beth Museum, em Tel Aviv, foi invadido por ladrões em 22 de maio. Eles levaram trinta e quatro objetos, entre eles livros feitos de metais preciosos, manuscritos em pergaminhos e livros impressos. O material pertencia à família Gross e estava no museu em exposição temporária chamada Journey to no end of the world.

${ }^{24}$ Endereço eletrônico: http://www.rbms.info/committees/security/theft_reports/index.shtml 
2004 - Em maio foram subtraídos e danificados livros e mapas de Geologia da University of Calgary's MacKimmie Library, no Canadá. Não foram dados maiores detalhes sobre o crime. Mas a perda foi avaliada em aproximadamente US\$18 mil. Em dezembro, jovens agrediram fisicamente o bibliotecário das coleções especiais da Transylvania University Library, nos Estados Unidos, e levaram consigo, entre outros materiais, desenhos de John James Audubon e uma primeira edição da Origem das espécies, de Charles Darwin. Quatro pessoas de 20 anos de idade foram presas em fevereiro de 2005.

2005 - Uma impressão de Earl of Loudoun foi furtada da Thomas Balch Library, na Virgínia, Estados Unidos. O diretor da biblioteca acredita que ela foi levada no dia 13 de maio, após o encerramento das atividades. Duas edições raras do Book of Mormon impressos na década de 1840 foram retiradas da Church of Jesus Christ of Latter-day Saints' Institute, em Salt Lake City, nos Estados Unidos. Suspeita-se que o furto tenha acontecido entre 24 de outubro e 08 de novembro. Os livros foram avaliados em aproximadamente US\$60 mil.

2006 - Uma edição do Astronomicum Caesareum, do Petrus Apianus, publicada em 1532 foi levada do Peuerbach Castle, na Áustria. O incidente foi descoberto em 26 de agosto, mas pode ter ocorrido entre os dias 23 e 26. Demorou-se a descobrir o furto, pois outro livro foi posto em seu lugar.

2007 - Um manuscrito italiano do século XVIII foi retirado de uma vitrine na área de coleções especiais da Charles E. Young Research Library, da University of California, Los Angeles, nos Estados Unidos, entre 08 e 12 de fevereiro. Não foram dados maiores detalhes sobre o crime, mas a obra foi avaliada em US\$ 7,5 mil. Em agosto, numa inspeção de rotina, foram dados como desaparecidos dois mapas de 1482, da edição de Ptolemy's Cosmographia, na Biblioteca Nacional da Espanha. Os dois mapas foram encontrados: um nos Estados Unidos, na posse de um colecionador de Nova lorque, e o outro na Austrália, após ser comprado por um negociante de antiguidades em um leilão em Londres.

2008 - A bibliotecária chefe do Rutherford B. Hayes Presidential Center, em Ohio, nos Estados Unidos, notificou, sem dar detalhes, o desaparecimento dos livros raros 
Maxwell Code e The Freeman Code, em 25 de agosto. Os livros foram encontrados em abril de 2009 e os dois ladrões foram presos.

2009 - Em abril de 2009 foi furtado do History Museum, da cidade de Kotel, na Bulgária, o livro Riben Bulvar, compilado por Dr. Peter Beron. Os bandidos deixaram uma réplica no lugar do original. Em setembro foi dada falta de oitocentos e oito documentos da Ohio State University Libraries, nos Estados Unidos, no momento em que faria a mudança destes itens para exposição na William Oxley Thompson Memorial Library.

2010 - Em fevereiro, ladrões arrombaram estantes com portas de vidro da Northwich Library, Inglaterra, e levaram os títulos Anglorum Speculum the Worthies of England in Church and State; Howson and Rimmer, Chester As It Was; Britton's Cheshire; Britton Bishop Hanley, Birds of Alderely; Cheshire Extract from unidentified work; Hanshall History of County Palatine; Holland General View of the Agriculture of Cheshire and Irvine_-History of Winnington Hall. Em março, a polícia de Israel pediu ajuda da população para tentar encontrar manuscritos escritos por Maimondes que haviam desparecido da Tel Aviv's Beit Ariela Library.

2011 - No dia 05 de julho foi notada a falta do Codex Calixtinus, na Catedral de Santiago de Compostela, Espanha. Não havia sinais de arrombamento no local. O livro foi encontrado no ano seguinte com um homem que havia sido caseiro e eletricista temporário na catedral.

2012 - No dia 07 de junho, o Hill Museum \& Manuscript Library, nos Estados Unidos, anunciou o sumiço de três volumes. Um deles havia sido usado no dia anterior, no período da tarde, em um seminário.

2013 - O mais famoso caso deste ano é o caso citado acima pela notícia dada por Gauz (2013), da Biblioteca Girolamini, em que o criminoso era o diretor desta instituição.

2014 - Em 26 de maio McGarry (2014a) noticiou que há algumas semanas antes a Polícia Nacional Irlandesa havia sido chamada para averiguar a descoberta do sumiço de algumas obras do All Hallows College. Esta notícia diz que estão 
desaparecidas 37 gravuras do séc. XVIII do artista italiano Giovanni Battista Piranesi, uma primeira edição, em dois volumes de um livro de Isaac Newton, o livro St John Chrysostom's Sermon on Penitence de 1484, um roteiro enviado por George Bernard Shaw ao Fr Joseph Leonard, além de correspondências trocadas entre eles. Em 27 de maio McGarry (2014b) diz que a porta voz da instituição alegou que as obras dadas como desaparecidas são 15 gravuras emolduradas, as gravuras de Giovanni Battista Piranesi, sete livros que teriam valor entre 50 e 2.500 euros, e dois volumes datados de 1484 avaliados entre 3.000 e 6.000 euros, e que não se tinha notícia sobre as outras obras apontadas no artigo anterior. Apesar do desparecimento das obras a porta voz da instituição disse que eles não tinham suspeita sobre apropriação indébita da obra.

Os exemplos acima mostram que são frequentes os roubos e furtos a livros raros e que o problema não é pontual, pois não ocorrem em um único lugar e em um determinado espaço de tempo; ou seja, eles comprovam que os livros são alvo de ladrões tanto quanto as pinturas, as esculturas e os objetos arqueológicos. As notícias mostram a necessidade das bibliotecas se protegerem de forma sistemática contra esse tipo de crime. As diversificadas estratégias de roubo mostram em alguns casos até mesmo o envolvimento de bibliotecários. A recuperação das obras não ocorre também na velocidade em que acontecem os roubos e furtos.

\subsubsection{Roubos e furtos de livros raros no Brasil ${ }^{25}$}

O Brasil também faz parte da lista de países que sofrem com roubos de livros raros. Gauz (1994) mostra dois roubos praticados em bibliotecas localizadas no Rio de Janeiro, mas os nomes das instituições não foram revelados. O primeiro ocorreu em 1987 e o usuário teria devolvido aos funcionários da seção apenas alguns dos livros raros que havia consultado, colocando as demais em uma pasta. Mesmo o ladrão tendo passado por revista ao sair da biblioteca, a segurança não o questionou sobre os volumes. A partir desse episódio, várias medidas de proteção foram

\footnotetext{
${ }^{25}$ Os casos a partir do ano 2000 são analisados mais detalhadamente no tópico 4.2 Segunda etapa Casos de roubo e furto de livros raros, deste trabalho.
} 
tomadas, como a proibição de entrada com bolsas e sacolas na seção de livros raros e o aumento da vigilância; além disso, a consulta passou a ser feita na própria sala onde trabalha o responsável pela coleção.

O segundo caso relatado por Gauz (1994) ocorreu em 1988, quando os funcionários deram falta do livro Notícias curiosas e necessárias das cousas do Brasil, de Simão de Vasconcellos, impresso em Lisboa, em 1688, que havia sido consultado por um usuário que se identificava como professor universitário. Verificando o histórico de consulta deste pesquisador foi possível constatar o desaparecimento de 14 obras. Como medida emergencial, foram contatadas várias livrarias e, explicado o ocorrido, uma delas havia comprado quatro folhetos holandeses do suspeito. Os mesmos foram devolvidos à instituição de origem. Nos dois casos relatados não foi possível a prisão dos suspeitos porque os mesmos não estavam portando quaisquer dos livros desaparecidos.

Roubos e furtos mais recentes de livros são noticiados por Kushnir (2009), que, a partir de matérias publicadas na mídia, do Museu Nacional e da Biblioteca do Jardim Botânico do Rio de Janeiro, em 2004; da Biblioteca Mário de Andrade, em 2006; e do Museu Paraense Emílio Goeldi, em 2008. No Museu Nacional o crime só foi divulgado a partir da devolução de algumas obras via correio. Do Museu Nacional foram levados 13 livros raros e 11 foram danificados. Entre as peças levadas está uma obra em latim de Hans Staden, datada de 1592, sobre índios do Brasil e da América do Sul, e um livro de 1860 de Charles Ribeyrolles com fotos de D. Pedro II e da família imperial. O sumiço das obras foi descoberto após um pedido de consulta de um usuário (ROUBADOS..., 2004; VIANNA, 2004).

A Biblioteca Pública Mário de Andrade, em São Paulo, também teve obras roubadas, em 2006: foram levadas várias gravuras de Debret, presentes no livro Voyage pittoresque et historique au Brésil; gravuras de Rugendas, retiradas do livro Malerisches reise in brasilien; de Steinmann, no livro Souvenirs do Rio de Janeiro; e três gravuras do artista Karl Hermann Konrad Burmeister; além do livro de orações Hore intemerate Beate Marie Virginis, de 1501 (BIBLIOTECA..., 2006). O sumiço das obras foi descoberto por meio de uma solicitação de empréstimo para compor uma exposição. Com isso foi feito um levantamento e se descobriu a ausência de mais 
obras (OBRAS RARAS..., 2006). Também em 2006 a Biblioteca conseguiu resgatar alguns livros postos em leilão: Memórias phostumas de Bras Cubas (1881), de Machado de Assis; As primaveras (1889), de Casemiro de Abreu; O malasarte (1911), de Graça Aranha; e Álbum de aves amazônicas (1900), de Emílio Goeldi, obras estas que não foram levadas na ação mencionada anteriormente, mas em outra ocasião (MARIO DE ANDRADE..., 2006).

Também em 2006 foi roubada a Biblioteca Pública do Paraná, localizada em Curitiba. Os ladrões levaram 120 exemplares raros. O sistema de segurança da instituição é precário e há suspeita da participação de funcionários na ação, que provavelmente foi realizada no fim de semana, quando só um guarda faz a segurança de toda a Biblioteca. Decidiu-se fazer investigação interna antes de avisar às autoridades policiais. Foram levantadas suspeitas sobre um usuário jovem, alto, moreno e que sempre usava capa de chuva, que não foi mais visto após o início das investigações (PREJUIZO..., 2006). Os livros levados eram de escritores brasileiros famosos, como Machado de Assis, Érico Veríssimo e Lima Barreto. Também foram levados livros de História Natural e Geografia brasileira, escritos na segunda metade do século XIX e contendo muitos mapas (TORTATO, 2006).

Em 2008, na coleção de obras raras da Biblioteca Domingos Soares Ferreira Penna, do Museu Emilio Goeldi, em Belém, no Pará, foram roubados 40 títulos raros (65 exemplares). As publicações roubadas datam dos séculos XVII, XVIII e XIX e, dentre elas, destacam-se in-fólios de Des Murs, Hernandez, Meriaen, Mikan, Piso, Pohl, Sagra, Spix e Wied-Neuwied. Segundo o diretor em exercício do Goeldi, Nelson Sanjad, o roubo foi descoberto durante treinamento para manuseio da coleção. O controle do acesso à coleção era precário e várias obras tiveram gravuras arrancadas com estilete (ROUBO DE..., 2008; ROUBO PODE..., 2008).

Em fevereiro de 2012 houve o crime contra a coleção de obras raras do Instituto de Botânica de São Paulo, onde três assaltantes armados renderam funcionários do local e se apossaram de três títulos (15 volumes) que traziam anotado em um papel. São os livros Sertum palmarum brasiliensium, de 1903 (dois volumes); Flora fluminensis, de 1827 (11 volumes); e Bambusees, de 1913 (dois volumes) (MANSO; GODOY, 2012; BEDINELLI, 2012). Além da anotação que os 
ladrões traziam, o fato dos mesmos terem dito que as obras seriam enviadas para fora do país permite verificar que foi um ato encomendado. $O$ ato criminoso foi gravado pelas câmeras de segurança. Seis meses antes do roubo, a Polícia Federal havia interceptado ligações telefônicas onde os presidiários falavam sobre um plano de roubar o Instituto de Botânica, o que foi avisado à direção do mesmo, que, com a informação, tomou providências reforçando a segurança e instalando câmeras próximas à biblioteca (INSTITUTO..., 2012; PF..., 2012); estas medidas não foram suficientes para evitar o crime ocorrido, mas revelou uma conexão com o plano interceptado anteriormente.

Os livros foram recuperados dois meses após o roubo, por meio de investigação policial. Os policiais interromperam as operações de mudança de local dos livros e os encontraram em sete sacos de lixo em um bairro da zona sul de São Paulo. No entanto, as notícias de resgaste das obras falam sobre a recuperação de 22 volumes (RODRIGUES, 2012; VALOTA 2012), o que diverge das notícias na época do roubo, que falavam em 15 volumes (MANSO; GODOY, 2012; BEDINELLI, 2012).

No dia 08 de agosto de 2013, cinco bandidos armados fizeram reféns funcionários, voluntários e visitantes do Centro de Ciências, Letras e Artes (CCLA) de Campinas e levaram cerca de 100 obras raras. A ação criminosa durou cerca de uma hora e quinze minutos e ao menos 13 pessoas foram rendidas (QUADRA, 2013). Entre as obras levadas estão 11 livros escritos no início do século XIX pelo francês Auguste Saint-Hilaire sobre a flora brasileira, três peças do Museu Campos Sales (presidente da República de 1898 a 1902 e nascido em Campinas), que funciona no local; e uma carta do imperador chinês Guangxu (1875-1908) ao então presidente (LADRÕES ROUBAM..., 2013).

Com exceção dos dois últimos crimes relatados (Instituto de Botânica de São Paulo e CCLA) e o ocorrido no Museu Chácara do Céu, que tiveram o uso de arma de fogo, os demais foram descobertos apenas quando da necessidade de uso do material subtraído. Este dado dá indícios de possível participação de funcionários das instituições nos crimes, ou da precariedade dos sistemas de monitoramento da coleção ou, ainda, da elevada perícia dos bandidos, que provavelmente são 
participantes de quadrilhas especializadas nesse tipo de crime; ou mesmo o conjunto de todas essas alternativas. Seja como for, mostra que é necessário o entendimento de como conter as investidas nesse tipo de coleção.

\subsection{Segurança contra roubo e furto}

O contexto apresentado ao longo dos capítulos anteriores, mostrando os vários roubos a bens culturais de toda natureza, incluindo livros raros, traz preocupações sobre a proteção que deve ser empregada nas instituições que fazem guarda destes acervos. Ao pensar em segurança é preciso ter em mente que este processo não significa apenas colocar equipamentos eletrônicos, mas exige uma mudança na cultura institucional, pois é imprescindível, neste caso, o trabalho em equipe, já que planejamento, execução e controle geralmente envolvem todos os funcionários da instituição, onde cada um terá seu papel na aceitação e manutenção do projeto. De nada adianta ter um circuito de vigilância interna por câmeras e alarmes de emergência se a equipe de segurança não souber reconhecer as possíveis atividades que trazem risco ao local, ou mesmo não saiba agir de forma rápida e eficaz para evitar algum sinistro, não tendo ideia do seu campo de atuação e não sabendo a quem pedir apoio em situações que fujam do seu domínio.

\footnotetext{
É importante ressaltar que os sistemas de segurança instalados não suprirão totalmente a segurança do edifício sem um plano de segurança operacional. Todo o sistema implantado pode falhar caso os procedimentos que dependam dos vigilantes ou funcionários não sejam atendidos (ONO; MOREIRA, 2011, p. 72).
}

As etapas que envolvem um bom plano de segurança vão da escolha e treinamento da equipe de limpeza ao uso de equipamentos eletrônicos para vigilância e controle de acesso ao setor e à instituição como um todo; ou seja, no plano de segurança devem estar contempladas todas as medidas preventivas para evitar o roubo de um exemplar, o que exige um estudo detalhado de todas as condições às quais o acervo está submetido, tentando identificar, de forma sistemática e abrangente, as variáveis que podem favorecer a ação dos criminosos. Portanto, uma segurança eficaz reúne métodos eletrônicos de controle e detecção (alarmes contra arrombamento e movimento, câmeras de vigilância, controle de 
acesso biométrico, etc.), contenção por meio de barreira física (portas, grades, paredes e outros), pessoal treinado e em quantidade adequada e um completo e abrangente plano de segurança. Serão traçados os limites de acesso, feita a divisão de funções para o funcionamento adequado da proteção, além do treinamento para rápida ação a todos os possíveis riscos trazidos ao acervo e à instituição. Todas as recomendações anteriores podem ser identificadas na obra de Silva et al. (2006), que trabalha com as condições de segurança de acervos em todos os locais e situações em que o livro raro possa estar, como sala de reserva, setor de restauração, local de exposição, em empréstimo a outra instituição, em consulta ou em circulação interna na instituição de guarda.

\subsubsection{Proteção ativa e passiva}

Ono e Moreira (2011) tratam da segurança em museus, mas seus conceitos podem ser usados também em arquivo e bibliotecas, como também no contexto dos livros raros. Para as autoras existem dois tipo de proteção, a ativa e a passiva. A proteção passiva é aquela ligada aos elementos construtivos de um edifício ou área, pois sua finalidade básica é agir como barreira para impedir ou dificultar a ocorrência de um evento indesejado; enquanto proteção ativa é aquela que deve ser estimulada para entrar em ação, como por exemplo, os sistemas de alarmes (ONO; MOREIRA, 2011). Os equipamentos de vigilância, sinalização, proteção e contenção, necessários para este cuidado podem ser de diversos modelos, marcas e preços. A escolha está condicionada à verba disponível, ao tamanho e à importância da coleção e do plano adotado para a segurança do acervo.

As barreiras físicas para evitar a invasão indevida do acervo podem contar com o reforço do material usado nas portas, nas trancas, nas paredes, no teto e nas janelas, com o intuito de dificultar ao máximo o acesso dos ladrões por invasão. Resource the Council for Museums, Archives and Libraries (2003) traça vários procedimentos que devem ser observados e adotados na segurança predial, como por exemplo, a averiguação do perímetro; ou seja, controle da área externa do 
prédio, que pode servir de esconderijo para pessoas mal intencionadas, sendo sua monitoração também útil na antecipação de possíveis ações criminosas.

Para o ACRL/RBMS Guidelines... (2009), a instituição deve ter saídas de emergência, mas estas não podem ser usadas como portas de circulação usual. As diretrizes também mostram que a área de consulta deve ser o único local de circulação e permanência dos pesquisadores, contendo armários para guarda de material pessoal, sendo vetado o acesso às áreas de trabalho e guarda de acervo.

O prédio deve ser feito preferencialmente de materiais resistentes à invasão, assim como a quantidade de portas e janelas deve ser reduzida ao mínimo possível, satisfazendo apenas à necessidade de acesso, ventilação e iluminação, evitando assim o exagero destes espaços, que podem ser usados para facilitação da fuga no caso de roubos. Também devem ser monitorados e reforçados os materiais que integram claraboias e dutos de ventilação, pois podem servir de ponto para escoamento de materiais e evasão de criminosos, assim como as saídas de emergência. Para as saídas de emergência existem sistemas que podem ser ligados à detecção de incêndio para a abertura das portas (RESOURCE THE COUNCIL FOR MUSEUMS, ARCHIVES AND LIBRARIES, 2003).

As medidas passivas de segurança que abrangem o envoltório do prédio e
seu interior devem combinar os elementos construtivos com a segurança. O
material utilizado na composição dos caixilhos, o tipo de vidro, dobradiças e
fechaduras utilizadas em janelas e portas, a estrutura de lajes, paredes e
pisos, entre as diversas características construtivas, são ferramentas
importantes no projeto de segurança, já que sua resistência mecânica pode
determinar o grau de dificuldade para uma invasão. (ONO; MOREIRA,
2011 , p. 31)

Edifícios vizinhos à instituição que talvez não possuam segurança adequada podem servir de facilitador ao acesso de ladrões; portanto, devem ser considerados na elaboração do plano de segurança, havendo reforço nos acessos entre os prédios. Silva et al. (2006) recomendam que a segurança física seja exercida em todo o prédio, mesmo nele havendo instituições distintas. Segundo as autoras, as preocupações maiores estão nas condições de resistência das portas, janelas e fechaduras, com a designação de pessoas que façam vistorias diárias, assim como deve ser estabelecido o controle rigoroso do acesso às chaves e à coleção. 
A proteção ativa, segundo Ono e Moreira (2011), divide-se em três categorias. A primeira consiste nos detectores de intrusão, com sensores que indicam a presença de indivíduos indesejados, podendo serem aplicados tanto no ambiente interno como externo, com variadas tecnologias de acionamento, como uso de infravermelho, acionamento por impacto, vibração ou micro-ondas. A segunda corresponde aos sistemas de controle de acesso, com a adoção de fechaduras que o controlam, utilizando cartões magnéticos, leitores biométricos ou outra tecnologia, ou ainda o uso de catracas e detectores de metais. Na terceira categoria estão os sistemas de monitoramento, com circuito fechado de TV, fazendo a vigilância dos ambientes externos e internos da instituição, usando câmeras e vídeos.

Sobre os sistemas de segurança automatizados, no contexto das bibliotecas e dos arquivos, é possível ver que ele serve a três propósitos:

Um sistema de segurança automatizada serve a três propósitos principais. Em primeiro lugar, a mera presença de um sistema pode ter um efeito dissuasor para o crime. Em segundo lugar, se ocorrer uma intrusão, isso vai ser detectado. Finalmente, o sistema irá notificar o pessoal apropriado, fazendo possível a apreensão do intruso. (BROWN; PATKUS, [20--?], online, tradução nossa)

Silva et al. (2006) mostram como devem ser os procedimentos adotados para implantação, monitoração e manutenção dos sistemas de alarme e TV, pois os mesmos devem ter planos diferentes para os diversos horários da instituição, já que a detecção esperada será uma no horário em que a instituição está fechada e outra quando está aberta. As autoras também alertam para a necessidade de sistemas alternativos de manutenção de energia, para que os equipamentos eletrônicos de vigilância não desliguem em caso de ausência do abastecimento elétrico usual.

Outro item importante é dar todas as condições para que a equipe de segurança haja de forma rápida e eficaz caso um sinistro de qualquer ordem aconteça, sendo possível fazer contato externo para pedido de reforços. 


\subsubsection{Conhecendo o acervo}

Um dos passos, se não o primeiro, para se criar um plano de segurança é conhecer bem o acervo para o qual será desenvolvido o projeto de proteção. É necessário conhecer todas as características de todos os exemplares que compõem a coleção. Em uma situação ideal, isso auxilia na identificação dos exemplares em casos de possível devolução dos mesmos quando houver roubo ou furto, além de servir como parâmetro para a sistematização de uma segurança diferenciada sobre os mais importantes. Da mesma forma, deve ser feita averiguação constante da localização dos exemplares que compõem o acervo, pois isto ajuda para que não ocorra o mencionado em alguns casos citados: só se descobre o roubo de um livro após a denúncia de desconhecido, na devolução de exemplares ou na solicitação de consulta em que o livro não será achado no lugar que the cabe. Neste sentido Almeida (2011, p. VII) diz que "não é possível pensar em estratégias de segurança sem que essas sejam precedidas do conhecimento detalhado dos acervos legalmente protegidos. Só se protege o que se conhece".

O ACRL/RBMS Guidelines... (2009) instrui o conhecimento do acervo como ferramenta de proteção e recuperação de obras, pois, segundo as diretrizes, quando um acervo está bem descrito, torna-se mais fácil a identificação e recuperação das obras em caso de roubo ou furto. Portanto, as diretrizes defendem uma descrição minuciosa de todas as características do livro, além de uma pesquisa bibliográfica que ajude a identificar a importância de um exemplar. Elas também apontam a importância do inventário periódico para identificação de livros desaparecidos.

No caso de livros, um título pode ter inúmeros exemplares; portanto, é importante que seja possível identificar, no meio de tantos, qual é o exato volume que pertence a determinada instituição. Para estabelecer prioridades de salvamento, nível de segurança, conservação e restauração é imprescindível que se tenha conhecimento da importância de cada exemplar dentro da coleção.

$\mathrm{Na}$ tentativa de conhecer melhor a coleção, o mais indicado é realizar um inventário, pois assim é possível ter a certeza do que há ou não no acervo e rever se o que consta em catálogo realmente se encontra no lugar que deveria estar. Cunha 
(2008, p. 214) descreve o inventário como sendo a "operação periódica, geralmente anual, que se destina a verificar a integridade das coleções de uma biblioteca, feita com auxílio do catálogo topográfico ${ }^{26 "}$. No caso de livros raros, a execução do inventário periódico pode ajudar na identificação de livros furtados e no acionamento rápido das autoridades, evitando que o desaparecimento dos itens seja identificado apenas muitos anos depois do ocorrido. Prott (2004, p. 215), apesar de tratar de museus, destaca a importância do inventário, que também pode ser relacionada ao contexto de livros raros:

Em qualquer plano de segurança é essencial conhecer os conteúdos do museu. Para este fim, o acervo deve ser todo inventariado. Os inventários têm que ter bastante informação para permitir a identificação verificável de um objecto quando achado, encontrado pelas autoridades públicas como suspeito ou à venda, localmente ou no estrangeiro. (PROTT, 2004, p. 215)

Portanto, para a simples averiguação da presença de um exemplar no local que the é destinado dentro da coleção é preciso realizar o inventário topográfico; mas também se pode realizar, em outro momento, um inventário detalhado das características de cada exemplar. No entanto, este último é mais demorado que o primeiro. Entre as estratégias de gestão e segurança de coleções apresentadas por Brown e Patkus ([20--?]), no sentido de conhecer o acervo, está a realização regular de invetário e a descrição física dos mateririais valiosos, para sua identificação em caso de roubo ou furto.

Outro processo que auxilia no conhecimento e controle do acervo e na identificação das peças que o compõem, para aqueles que ainda não foram tratados e catalogados, é a técnica conhecida como fotobibliografia ou didascálica (PINHEIRO, 2007). Esta prática consiste na transcrição minuciosa da folha de rosto de cada volume, levando em consideração o formato da letra, a quebra de linha e as informações visuais.

\footnotetext{
${ }^{26}$ Catálogo topográfico: "o que apresenta as entradas ordenadas de acordo com o arranjo ou localização dos documentos nas estantes” (CUNHA; CAVALCANTI, 2008, p. 74).
} 
A fotobibliografia constitui um recurso, (sic) que tira do estágio "zero" aquelas coleções que não foram submetidas a qualquer tratamento biblioteconômico; cria condições de controle sobre acervos de memória que devem ser salvaguardados; e tem caráter permanente - seus dados e sua estrutura podem alicerçar ou incorporar-se (sic) a quaisquer outros métodos de descrição bibliográfica. (PINHEIRO, 2007, p. 5)

Abaixo, segue um exemplo de didascálica, retirado do Catálogo de obras raras ou Valiosas da Biblioteca Pública do Estado (1972), referente à folha de rosto da Figura 24:

DESCRIPÇAM / COROGRAFICA / DO REYNO DE / PORTUGAL, / QUE CONTÉM / HUMA EXACTA RELAÇAM DE SUAS PROVINCIAS, I Comarcas, Cidades, Villas, Freguezias, montes, rios, portos com / a sua situação, extensão, e limites, a qualidade de cada paiz, as / fortalezas, o numero, costumes, e commercio dos seus / habitantes, as principaes dignidades Ecclesiasticas, os / títulos honoríficos de sua Nobreza, a serie, e ac- / çoens mais famosas de seus Reys, e tudo o mais / memorável desta antiga, e ilustre / Monarchia. / COMPOSTA POR / ANTONIO / DE OLIVEIRA FREIRE. / [grav.] / LISBOA: / Na Officina de BERNARDO ANTON. DE OLIVEIR. / [ fio] / Anno de M. DCC. LV. / Com todas as licenças necessárias.

Figura 24 - Folha de Rosto

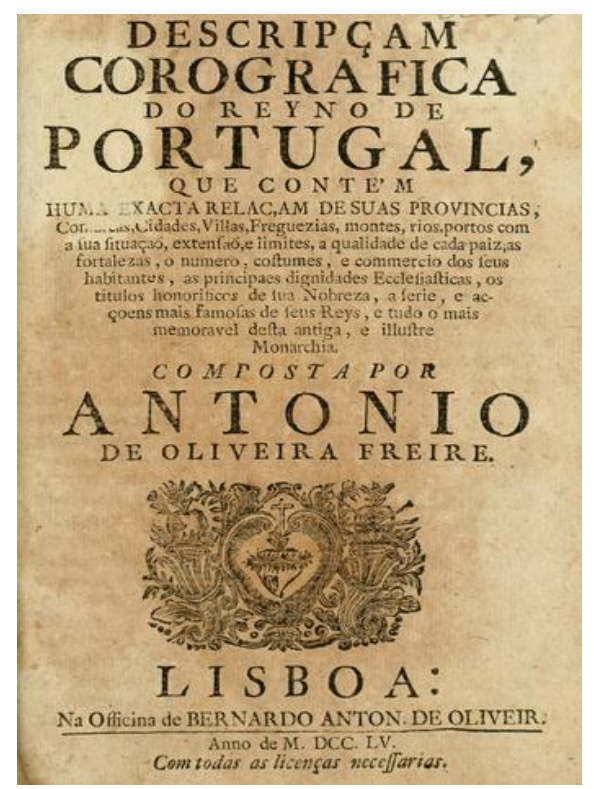

Fonte: Open Library, 2010.

Pinheiro (2007, p. 6) apresenta as vantagens de se usar essa técnica como metodologia de inventário de acervo antigo: 
a) rapidez, devido à facilidade de registro dos dados, não demandando a necessidade de conhecimentos especializados;

b) identificação de exemplares e de contrafações, pelo confronto e verificação de igualdade ou similaridade entre os dados compilados;

c) recuperação e reunião de segmentos de obras (volumes, tomos e partes), dispersos na área de guarda, em face da constatação de complementaridade entre os dados compilados.

Assim como o inventário e a fotobibliografia, a técnica chamada análise bibliológica pode ser uma ferramenta que aumenta o conhecimento sobre o acervo que a instituição detém. A análise bibliológica corresponde à técnica de descrever o livro página a página, procurando estabelecer todos os pontos que o individualize com relação aos demais, seja pelas características intrínsecas à produção do livro como a adoção de gravuras, erros de paginação, de impressão - ou pelas características extrínsecas, onde serão levantadas todas as marcas que foram adquiridas ao longo dos anos de uso daquele volume, como anotações, Ex libris, assinaturas, carimbos, entre outros aspectos.

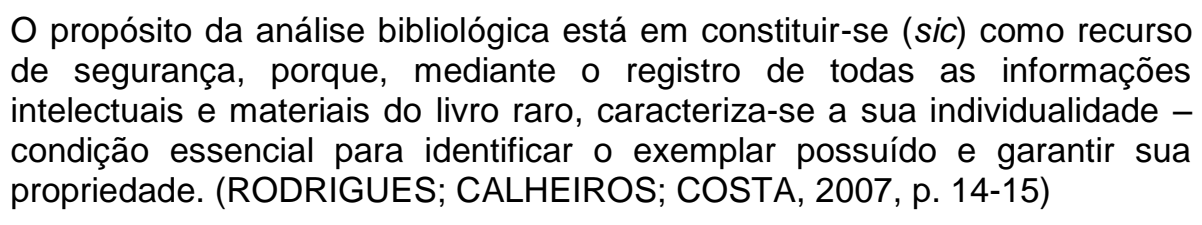

Gauz (1994) defende uma catalogação em nível detalhado, com características próximas ao que é feito na análise bibliológica, com levantamento das ações de inseto, anotações em páginas, selos, carimbos em determinados locais, que ajudem a identificar o livro. A autora ainda diz que algumas instituições não puderam reaver alguns livros roubados devido à ausência de alguma marca de propriedade ou descrição bibliográfica detalhada que pudessem legalmente relacionar a obra à instituição.

O Quadro 1, abaixo, traz alguns elementos que devem ser descritos no momento da análise bibliológica: 
Quadro 1 - Aspectos a serem observados, no colacionamento do livro raro

\begin{tabular}{|c|c|}
\hline 1 Suporte & $\begin{array}{l}\text { - } \text { natureza (papel, pergaminho, couros, tecidos) } \\
\text { - linha e marca d'água } \\
\text { variantes morfológicos (lado da carne/lado do pelo, } \\
\text { cicatrizes e defeitos do pergaminho; dimensões, } \\
\text { textura, cor e espessura do papel) }\end{array}$ \\
\hline 2 Capa & $\begin{array}{l}\text { - } \quad \text { cobertura (material, decoração) } \\
\text { - } \quad \text { encadernação original, de época, em estilo, especiais, } \\
\text { - } \quad \text { lombadicas, cortesanais } \\
\text { - } \quad \text { guarda, contraguarda, guarda volante } \\
\text { - complementos: garras, fechos, amarras, ornamentos }\end{array}$ \\
\hline 3 Texto impresso & $\begin{array}{l}\text { - } \text { mancha (título corrente, reclamo, assinatura) } \\
\text { - } \text { arranjo (em colunas, sobreposto, em corandel, em } \\
\text { fundo de lâmpada, em copo de médicis, em triângulo } \\
\text { espanhol) } \\
\text { - } \text { caracteres góticos, romanos, aldinos } \\
\text { - } \quad \text { títulos tipográfico-bibliológicos: parágrafos, posituras } \\
\text { - disposição do texto nas páginas, folhas, colunas }\end{array}$ \\
\hline 4 Ornamentação & $\begin{array}{l}\text { - } \text { gravuras (água-forte, buril, xilogravura, litogravura) } \\
\text { - aquarelas, iluminuras } \\
\text { - } \quad \text { assinaturas e marcas dos artistas gravadas ou } \\
\text { impressas } \\
\text { - elementos decorativos: vinhetas, cabeções, capitais } \\
\text { - marcas tipográficas e heráldicas }\end{array}$ \\
\hline $\begin{array}{l}5 \text { Marcas intrínsecas } \\
\text { e extrínsecas }\end{array}$ & $\begin{array}{l}\text { - marcas de propriedade e posse (carimbo seco, } \\
\text { carimbo molhado, Ex libris, ex dono, super libris, } \\
\text { marca de fogo, chancela) } \\
\text { - defeitos, incompletudes (originais e posteriores) } \\
\text { - anotações manuscritas (de época, atuais) } \\
\text { - marcas de comércio e intervenções (selos de livreiros, } \\
\text { etiquetas de encadernadores) e de preparo } \\
\text { biblioteconômico }\end{array}$ \\
\hline $\begin{array}{l}6 \text { Apresentação } \\
\text { material e aspectos } \\
\text { intelectuais }\end{array}$ & $\begin{array}{l}\text { - } \text { natureza da obra } \\
\text { - documentos encartados (carcela), dobrados, } \\
\text { desdobrados } \\
\text { - volumes unitários e coletivos } \\
\text { - marcas de interferências gráficas posteriores à edição }\end{array}$ \\
\hline
\end{tabular}

Fonte: Pinheiro $(2012$, p. 7$)$

O levantamento bibliográfico permite conhecer a importância do livro em seu contexto de publicação, seja pelo conteúdo, autor, encadernador, gravurista, impressor e tantos outros aspectos que o fizeram raro. No anexo B estão as referências de fontes bibliográficas indicadas por Pinheiro (2009b) e também por Meneses e Silva (2004) para esta especificidade. 
A fotobibliografia ajuda, portanto, no controle inicial de coleções não tratadas, de modo que sua execução vai documentar o que há no acervo. O inventário topográfico, executado em acervos já catalogados e classificados, indicará se os livros estão em seu devido lugar, ou mesmo o desaparecimento de um exemplar. A análise bibliológica individualizará cada exemplar, com a análise de suas características enquanto objeto físico; enquanto o levantamento bibliográfico irá mostrar a importância cultural e histórica de cada título e edição.

A realização destas atividades pode ajudar na segurança contra roubo e furto de livros raros, pois vai haver o controle de quais obras a instituição possui e se ela ainda está em seu poder; ou seja, tem-se o controle do que há na coleção, por meio da fotobibliografia, sendo possível verificar sua permanência ou desaparecimento pelo inventário topográfico. Assim como o levantamento das características que diferenciam um exemplar de outro do mesmo título e edição, feito pela análise bibliológica, a fotobibliografia também pode ajudar na hora de identificar um livro recuperado como sendo de determinada instituição, no caso de roubo e furto. $\mathrm{O}$ levantamento bibliográfico pode permitir à instituição criar programas diversificados de segurança para cada livro de acordo com um maior ou menor valor cultural/histórico e financeiro.

\subsubsection{Gerenciamento de risco}

O gerenciamento de risco abordado na Norma Australiana e Neo-Zelandesa de Gerenciamento de Riscos AS/NZ 4360:2004, que deu origem à norma ISO 31000 , trata da possibilidade de quantificar o risco por meio do estudo da probabilidade do evento acontecer e do impacto da ocorrência em determinado local. Para acervos de bens culturais, tal norma pode ser adotada para a estipulação de prioridades de ação dentro de um plano de preservação, onde, é claro, a segurança estaria contemplada.

A análise ou quantificação da magnitude dos riscos é feita a partir da quantificação da freqüência ou velocidade em que se espera que o dano ocorra, juntamente com a perda de valor para o acervo decorrente da extensão do dano causado e da fração afetada. Uma vez determinadas as magnitudes dos riscos para o acervo é possível compará-los e, juntamente 
com critérios complementares, estabelecer prioridades para seu tratamento e mitigação. (PEDERSOLI JR.; HOLLÓS, 2009, p. 78)

Os autores ainda explicam as etapas que envolvem o processo de gestão de riscos estabelecido pelas normas, onde estão presentes cinco níveis sequenciais e dois contínuos, como na figura abaixo:

Figura 25 - Processo de gestão

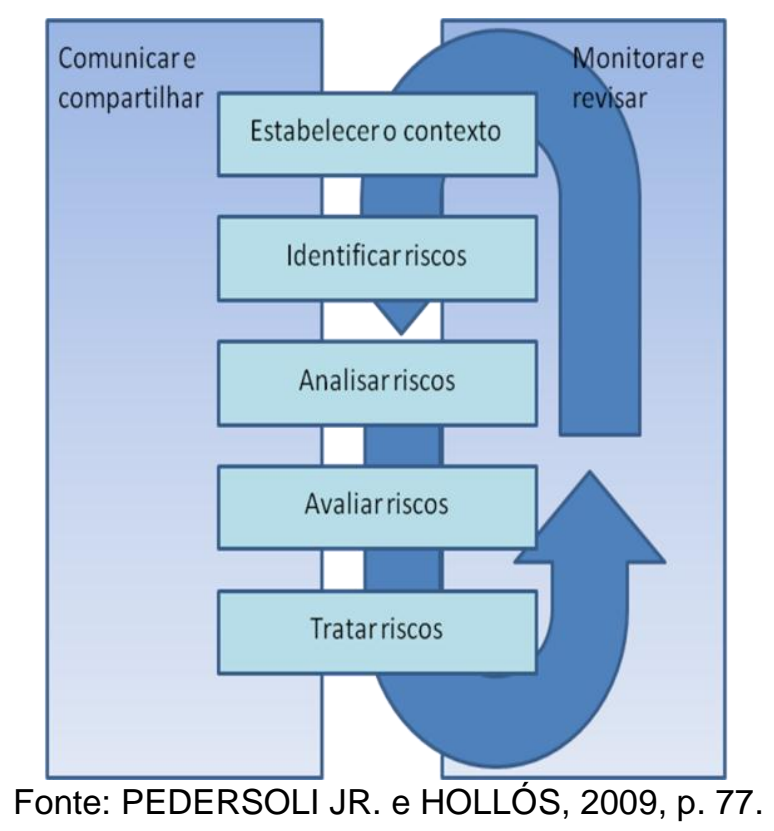

Estabelecer o contexto seria identificar os objetivos da instituição e definir os atores internos e externos envolvidos no processo de gestão de riscos, enquanto identificar riscos é a atividade onde todos os riscos que ameaçam a coleção serão estabelecidos de forma sistemática e abrangente. $\mathrm{Na}$ fase de análise dos riscos, os mesmos serão quantificados dentro da magnitude de risco, ou seja, será estipulado, por meio de padrões pré-adotados, um valor para cada risco, para que, na fase de avaliação, sejam traçadas as prioridades de ação para tratá-lo, reduzindo-o a níveis aceitáveis. Portanto, ao estabelecer o contexto, ou seja, ao identificar todas as ameaças à instituição é preciso estabelecer o perímetro de ação, considerando os envoltórios ou camadas de proteção que existem até chegar ao objeto em si, conforme a figura abaixo. 
Figura 26 - Níveis envoltórios

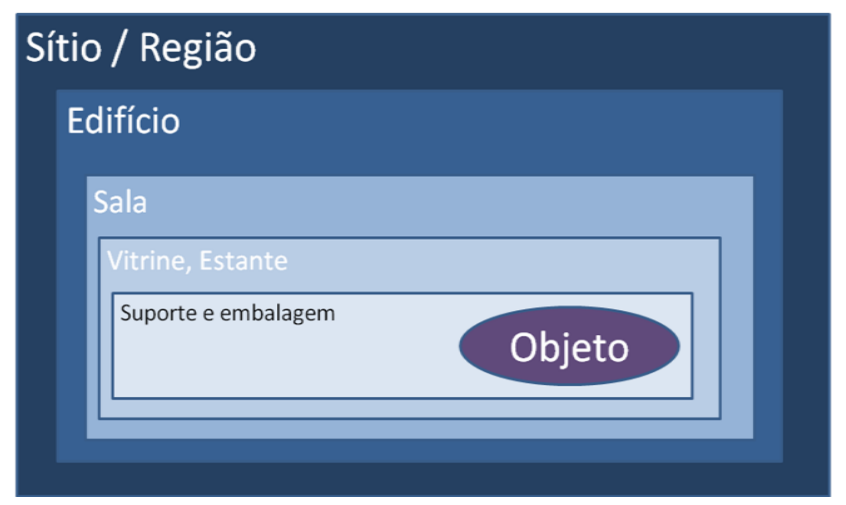

Fonte: MICHALSKI, 2004, p. 62.

Estabelecidos os riscos e os invólucros, a sistemática do tratamento pode ser distribuída nos seguintes estágios de controle do risco: evitar, bloquear, detectar, responder ao agente e recuperar o dano causado pelo agente. Esta etapa é feita para cada invólucro.

Em Pedersoli Jr. (2010) é possível ver um exemplo de análise de risco para um cenário específico, no caso, para danos e perdas causados por pestes:

Cenário de risco: Roedores entram na biblioteca através de fendas no edifício e roem as capas e blocos de texto de livros do acervo.

Todos os 10.000 livros da biblioteca se encontram em estantes abertas e podem ser facilmente alcançados. Todos os livros têm o mesmo valor (importância) para a coleção. A biblioteca localiza-se em uma área com elevada população de roedores. Incidentes com a presença de roedores na biblioteca têm ocorrido com uma frequência aproximada de um evento a cada 10 anos. O último incidente foi no ano passado, quando 1 roedor foi encontrado na área de acervo. Esperamos a ocorrência de pelo menos mais um incidente como aquele dentro dos próximos 10 anos. Uma vez que o pessoal da biblioteca tem consciência do problema, o acervo é monitorado frequentemente. Roedores entrando na biblioteca e roendo livros deverão ser descobertos dentro de 2 a 7 dias. Nesse período de tempo, o dano esperado seria a destruição parcial das capas de 2 a 5 livros. Julga-se que esse dano corresponderia a uma perda de valor de aproximadamente $0,1 \%$ para cada livro afetado.

De posse destas informações, o próximo passo é responder às perguntas:

A. Para eventos, com que frequência ocorre o dano? Para processos contínuos, com que rapidez o dano se acumula?

B. Qual será a perda de valor para cada objeto afetado? 
C. Qual a fração do valor total do acervo que será afetada?

Neste caso, a resposta para a pergunta A seria: aproximadamente uma vez a cada dez anos. Para a pergunta B: o dano esperado corresponde a uma perda de valor de aproximadamente $0.1 \%$ para cada livro afetado. Para a C: a fração do valor total do acervo afetada pelo risco está entre 2 (livros afetados)/10.000 (livros no acervo) e 5 (livros afetados)/10.000 (livros no acervo), ou seja, entre 0,02\% e 0,05\%. Fazendo a comparação destes dados com as duas tabelas também apresentadas por Pedersoli Jr. (2010, p. 94-95), disponíveis nos anexos C e D deste trabalho, é possível estipular pontuações retiradas da Escala $A B C$ (ANEXO $C$ ) referente às perguntas e depois determinar a prioridade de ação ao risco na Escala de Magnitude de Riscos (ANEXO D). Para o exemplo acima na Escala $A B C$, a resposta à pergunta $A$ tem pontuação 4 (quatro), enquanto a $B$ tem pontuação 2 (dois) e a $C$ pontuação 1,5 (um e meio). Como a Magnitude de Risco - MR é a somatória da pontuação de $A+B+C$, o MR é de 7,5 (sete e meio), que, na escala, corresponde a uma prioridade média, numa relação que tem prioridades baixa, média, alta, extrema e catastrófica.

Em Spinelli e Pedersoli Jr. (2010) é possível ver como o gerenciamento de riscos foi aplicado quanto à segurança contra criminosos na Biblioteca Nacional. A tipologia de riscos foi estabelecida como evento raro de impacto significativo ou evento esporádico de impacto moderado. Entre as possíveis causas foi visto o "elevado valor no mercado de arte ou demanda por colecionadores de itens do acervo da BN" (SPINELLI; PEDERSOLI JR., 2010, p. 31). Também foram estabelecidas medidas adotadas para os 5 estágios de controle de riscos; as principais foram:

\section{Evitar o risco:}

- Realizar a vigilância presencial de forma evidente;

- Solicitar sistematicamente a identificação dos usuários;

- Impedir a entrada de usuários portando bolsas, mochilas, etc.;

- Impedir a entrada de usuários portando originais ou fotocópias de livros, jornais, revistas, etc.; 
- Evitar o acesso de usuários às áreas de guarda;

- Realizar vigilância ostensiva 24 horas por dia no perímetro do prédio;

- Verificar sistematicamente a idoneidade e a capacitação dos prestadores de serviço que fazem a segurança;

- Informar os funcionários sobre as medidas de segurança.

\section{Bloquear o risco:}

- Manter as portas, janelas e demais dispositivos de segurança operando adequadamente;

- Realizar controle rigoroso das chaves;

- Assegurar que nenhuma porta das áreas de guarda, dos laboratórios ou de outras áreas "sensíveis" permaneça destrancada ou aberta além do estritamente necessário;

- Considerar a possibilidade de armazenar os itens mais valiosos do acervo em salas ou espaços adequados e seguros, de acesso restrito e dotados de cofre.

\section{Detectar o risco:}

- Assegurar, durante o horário de atendimento, a presença ininterrupta dos funcionários responsáveis pela vigilância dos espaços públicos;

- Manter rigorosamente o registro de acesso de funcionários às áreas de guarda de coleções do acervo;

- Instalar e assegurar o funcionamento adequado, por meio de manutenção preventiva e testes periódicos, de sistemas de sensores e alarmes de proteção, detectores de movimento, contatos magnéticos para portas e janelas, alarmes contra quebra de vidros, etc.

\section{Responder ao risco:}


- Assegurar que o pessoal da segurança esteja sempre presente em número suficiente e devidamente equipado;

- Proporcionar um canal de comunicação móvel entre as equipes de vigilância;

- Sensibilizar a polícia quanto à importância de uma resposta rápida e eficiente em caso de chamado.

\section{Recuperar o patrimônio:}

- Fazer rigorosamente o registro descritivo e fotográfico detalhado e atualizado de todos os itens do acervo;

- Sensibilizar a comunidade de comerciantes de obras de arte e antiguidades;

- Em caso de furto ou roubo consumado, acionar imediatamente a Polícia Federal, Interpol e demais autoridades;

- Em caso de furto ou roubo consumado, divulgar amplamente imagens e dados descritivos dos itens furtados.

As medidas adotadas neste processo abrangem todos os aspectos de segurança abordados neste trabalho, como a segurança física e eletrônica, além dos processos administrativos que envolvem 0 controle de todas as atividades relacionadas ao acervo.

\subsubsection{Plano de segurança}

O reconhecimento de todos os esforços para minimizar os riscos de qualquer dano ao acervo só será validado caso os estes estejam institucionalizados, ou seja, tenham a aceitação de todos os envolvidos e, principalmente, da direção da instituição. Um plano de segurança, documentado por escrito, ajuda a fazer com que todos tomem conhecimento de seus deveres dentro da segurança institucional, além de trazer os procedimentos adotados na rotina de trabalho que visam a diminuir as chances de roubo ou furto. Assim, esse plano também deve informar quais as ações devem ser tomadas, pela equipe de segurança e demais funcionários da instituição, 
na detecção de um crime em andamento; do mesmo modo que deve conter um plano de emergência no caso do crime ter sido bem sucedido.

[...] um sistema automatizado nunca deve ser a única proteção de uma instituição. Como a maioria dos furtos ocorre durante as horas de trabalho, e ocorrem devido a erros humanos, é essencial ter um plano de segurança amplo, que inclui estratégias de proteção às coleções durante o uso. (BROWN; PATKUS, [20--?], online, tradução nossa)

Para Brown e Patkus ([20--?]) o primeiro passo para implementação de um plano de segurança é a criação de um comitê. Esse comitê deve fazer um levantamento sobre segurança, identificar os maiores riscos de segurança, determinar o que deve ser feito sobre ele e escrever o plano de segurança. Para isso o comitê deve ter a autorização do diretor da instituição para agir. Para as autoras o plano de segurança, resumidamente, deve conter:

informações sobre quaisquer sistemas de segurança no edifício,
informaçoses sobre distribuição e controle de chaves do prédio e de qualquer
das áreas especiais de armazenamento, cópias de todas as políticas e
procedimentos relacionados com a segurança (usuários e equipe que usa a
coleção, as políticas de gestão da coleção, etc. ), uma lista de medidas
preventivas a serem realizadas, e uma lista de procedimentos para
responder a uma violação de segurança (por exemplo, um roubo em curso
ou que já tenha ocorrido). (BROWN; PATKUS, [20--?], online, tradução
nossa)

$\mathrm{Na}$ elaboração do plano de segurança, o ACRL/RBMS Guidelines... (2009) defende a indicação de uma pessoa da própria instituição para ficar responsável pela identificação dos riscos à segurança, chamado por ele de Library Security Officer (LSO). Esta pessoa deve ter total conhecimento sobre o acervo e suas necessidades de segurança, devendo estar em contato direto com a equipe responsável pela segurança geral da instituição. O LSO deve ser indicado pela direção, tornando-se o principal responsável pelo planejamento e administração do plano de segurança. O LSO também deve fazer o levantamento do acervo, revisar a estrutura física e treinar o pessoal. Para assessorar o responsável pela segurança, a instituição pode nomear uma comissão ou ainda fazer uso de um consultor externo, desde que seja qualificado e avaliado como uma pessoa confiável.

De uma forma ampla, Silva et al. (2006) mostram que, na elaboração de plano de segurança, deverão ser estipulados todos os detalhes envolvendo todas as medidas de segurança necessárias, com a criação de rotinas de segurança que 
estabeleçam, por exemplo, os horários de ronda, o modo como será feito o controle de chaves, as regras para consulta do acervo, as formas de se fazer a vigilância eletrônica, o controle das condições das barreiras físicas, os controles de acesso às áreas de guarda, as regras de empréstimo de obras, os cuidados na exposição, entre outras atividades. As autoras mostram ainda a necessidade do envolvimento de todos os funcionários, junto com a atribuição de responsabilidades, dizendo, por exemplo, que "o diretor da instituição é o primeiro responsável por todas as questões referentes à segurança", assim como "cada funcionário deverá tomar ciência sobre todas as questões de segurança e acatar suas respectivas responsabilidades" (SILVA et al., 2006, p. 21). Para Brown e Patkus ([20--?]) na elaboração do plano podem haver informações que devem ficar restritas aos funcionários do alto escalão da instituição, assim como, a produção pode se tornar cansativa devido a quantidade de itens a serem considerados, principalmente quando a instituição ainda não possui nenhum plano de segurança. Portanto, as autoras recomenda que o processo seja dividido em etapas para não sobrecarregar os funcionários e ampliar a sensação de realização dos procedimentos.

No plano devem estar estabelecidos todos os procedimentos de ação pela segurança no momento em que algo for detectado, pois, caso sejam flagradas ações de roubo pelo circuito interno de TV ou algum alarme seja acionado, é preciso que todos saibam exatamente o que fazer para evitar que o crime seja consumado. $O$ ACRL/RBMS Guidelines... (2009) defende que, na deteç̧ão de um crime em andamento, devem ser seguidas as políticas institucionais, onde se inclui o plano de segurança, além das leis estaduais e nacionais. As diretrizes mostram ainda que deve ser solicitada a prisão do suspeito por um policial e que todos os detalhes referentes à ação devem ser documentados e relatados por todos os envolvidos, pois podem ajudar no caso de haver um julgamento do criminoso.

Outros aspectos relacionados à manutenção da integridade física da coleção também serão estabelecidos, como, por exemplo, a guarda das chaves, a localização das cópias das mesmas, as pessoas responsáveis pelas chaves e por suas cópias; a combinação numérica que abra um possível cofre, as pessoas que terão este segredo, a troca deste segredo no caso de substituição de pessoas; o 
controle do acesso aos armazéns de livros; estipular o programa de exposição e o programa de empréstimo entre instituições, entre outras atividades.

Cada biblioteca difere de outra e, sendo assim, cada uma deve ter seu programa de segurança cobrindo os itens necessários: edifício, funcionários, usuários e coleção. Deve esse programa estar impresso e ser do conhecimento de todos os funcionários para que se possa contar com sua colaboração na execução de todos os itens. (SILVA; LANE, 1989, p. 126)

As chaves ou cartões de acesso são materiais vulneráveis, segundo o ACRL/RBMS Guidelines... (2009). Portanto, as diretrizes mostram que estes itens devem ter um controle rigoroso, sendo as chaves distribuídas de acordo com as necessidades e somente a pessoas autorizadas, com mudança do segredo das fechaduras à medida que um funcionário perde o direito de acesso à coleção. Todos os registros devem ser mantidos pelo maior tempo possível, sendo recomendada a guarda permanente dos mesmos.

Gauz (1994) mostra que, no caso de empréstimo, todas as garantias de conservação e proteção devem ser dadas pela instituição requerente, e que toda instituição possui o direito de atender ou não ao pedido de empréstimo. Portanto, o plano de segurança deve estabelecer todos os procedimentos de acesso ao livro em todos os ambientes, internos e externos à instituição, seja no armazém de guarda, na sala de processos técnicos, no salão de leitura, na área de exposição, na remoção para restauração ou no traslado para empréstimo a outra instituição.

Um fator visto em alguns casos de roubo a livros raros foi o envolvimento de funcionários. Portanto, o plano de segurança deve conter processos que façam a vigilância constante daqueles que trabalham diretamente com a coleção, além, é claro, de excluir o acesso indevido daqueles que não têm função ligada ao setor. No plano de segurança devem estar contemplados os critérios de seleção dos funcionários que irão lidar diretamente com o acervo de obras raras. O ACRL/RBMS Guidelines... (2009) mostra que a equipe de trabalho deve conviver em uma atmosfera de confiança e interesse, pois funcionários descontentes podem descontar suas mágoas no acervo. As diretrizes ainda trazem que todos os funcionários ligados à coleção devem saber de suas responsabilidades legais e que os mesmos não devem fazer uso de materiais pessoais dentro da área de guarda, 
pois existem notícias de roubos em que havia participação das pessoas que trabalhavam no setor, tanto na subtração direta de exemplares, usando do seu posto para apropriação destes itens, quanto na facilitação do acesso dos criminosos ao ambiente de guarda dos livros. Em alguns casos de roubos de bens culturais não são encontrados indícios de arrombamento, ou seja, é provável que funcionários tenham facilitado a entrada dos criminosos ou eles mesmos tenham atuado no delito. Outros episódios mostram que os criminosos tinham conhecimento detalhado de toda a instituição, onde as obras se encontravam, sendo possível que tenham recebido informações de pessoas que trabalham no local. Por isso, em Resource the Council for Museums, Archives and Libraries (2003, p. 47) é dito que:

A seleção de pessoal é uma tarefa tão importante que justifica o esforço
necessário para averiguar se os antecedentes de um provável empregado
não representam nenhum (sic) risco para o museu. A importância do cargo
não tem qualquer implicação no que se refere à responsabilidade de um
empregado de museu no cuidado com as coleções: diferentes membros da
equipe podem ter acesso a muitas partes do edifício no curso de seus
serviços. Por exemplo, um vigia pode possuir as chaves do edifício e ter
muito mais oportunidades de acesso do que a equipe administrativa ou de
curadores.

O acesso ao material pelos pesquisadores deve ser registrado, sendo possível o acesso futuro a estes registros, que devem conter os dados pessoais de identificação do usuário, além de um modo de identificação física da pessoa e também devem remeter aos materiais usados, segundo o ACRL/RBMS Guidelines... (2009).

Silva et al. (2006) mostram que a movimentação dos exemplares dentro da própria instituição deve ser monitorada e documentada, com procedimentos de segurança em todos os ambientes, pois os planos e ações de segurança podem focar somente no local de guarda dos livros, esquecendo que os mesmos podem ser retirados deste ambiente para procedimentos em outras seções, como restauração e exposição.

O plano de segurança ainda deve contemplar medidas detalhadas de manutenção e atualização do próprio plano, dos processos diários de segurança e principalmente dos equipamentos eletrônicos. Alguns aspectos determinados nesse plano de segurança podem se apresentar inconsistentes na sua adoção diária, como 
também alguns funcionários podem sair da instituição e outros entrar, além dos equipamentos eletrônicos se tornarem obsoletos ou apresentarem defeitos. Portanto, deve existir na instituição um grupo que se reunirá frequentemente para reavaliação e reestruturação do plano de segurança, que deverá conter medidas que visem a identificar falhas nele, onde uma das ações pode ser a simulação de eventos, para testar se o que foi determinado está sendo adequadamente executado. Quanto à avaliação da polícia de segurança, Silva et al. (2006) dizem que é preciso fiscalizar o cumprimento das normas de segurança pelos funcionários da instituição, ver a rapidez e eficácia das respostas estabelecidas pelo plano, e avalizar a possibilidade de ampliar o plano caso necessário.

São necessários treinamentos periódicos com a equipe, pois é preciso que a mesma saiba agir correta e instantaneamente quando ocorrer algum roubo, da mesma forma que é preciso comunicar o plano de segurança aos funcionários que forem chegando ao longo do tempo. O ACRL/RBMS Guidelines... (2009) diz que o treinamento de pessoal deve ser uma alta prioridade para o LSO, enquanto Silva et al. (2006) também reforçam a questão do treinamento ao dizer que, para a política de pessoal, deve-se promover a capacitação do corpo funcional, com incentivo a atualização profissional, assim como este treinamento tem que ser feito de forma periódica. Brown e Patkus ([20--?]) complementam que além de treinados os funcionários devem ser encorajados a dar sua opinião e traz elementos que componham o plano de segurança. Para as autoras os funcionários também devem ser treinados de modo a sempre cumprirem as regras estabelecidas, pois, um clima de exceções rotineiras, pode gerar meios de prática de roubou ou furto.

Os equipamentos eletrônicos possuem vida útil limitada, sendo necessário que o plano de segurança contemple como serão feitos os reparos e reposições de equipamento que também se tornarão precários com a evolução da tecnologia. Assim, todas as questões que envolvam planejamento financeiro devem ser previstas e contempladas, para que a segurança do acervo não fique a mercê das surpresas. Ono e Moreira (2011) mostram que um plano de manutenção preventiva e periódica de um edifício ajuda a recuperar as condições de uso previstas incialmente, garantindo o bom desempenho da construção e dos equipamentos 
instalados, pois falhas nestes elementos podem causar prejuízos patrimoniais e requerer um alto custo de reparação.

\subsubsection{Digitalização e microfilmagem}

A digitalização ainda não é considerada uma medida de conservação no intuito de manter a informação por longo período caso haja perda do original, pois as mídias atuais ainda são consideradas instáveis quanto à sua durabilidade física, ou pela obsolescência das mídias, que traz muitas implicações que devem ser consideradas, como migração, emulação, encapsulamento ${ }^{27}$, entre outras medidas que também não garantem o acesso futuro a estes documentos.

A microfilmagem ainda é o mais recomendável como método de reprografia de preservação. Ao contrário dos documentos digitais, os microfilmes, se mantidos em umidade relativa e temperatura ambiente adequadas, podem ter vida útil de até 500 anos $^{28}$. "Vale dizer que o microfilme ainda se constitui no mais importante e válido meio de preservação de acervo raro, em termos legais, e é, até os dias atuais, utilizado nas políticas de reprodução e preservação de livros raros, por sua extensa durabilidade" (GAUZ, 2011, p. 161).

Contudo, a digitalização surge como método de disponibilização do conteúdo dos livros online, além de permitir, com o avanço tecnológico, cada vez mais, uma maior qualidade na reprodução. Para a segurança contra roubos de livros, a digitalização possibilita o acesso remoto e irrestrito ao acervo, diminuindo a necessidade do contato com o original.

O material impresso presente no setor estaria, a partir da digitalização, totalmente voltado para a preservação, tornando-se necessária uma política de restrição de acesso aos livros, exigindo justificativas para o contato com o original, uma vez que o conteúdo estaria disponível on-line. (GREENHALGH, 2011, p. 162)

\footnotetext{
${ }^{27}$ Estas e outras medidas serão explicadas adiante.

${ }^{28}$ Informação retirada do site da Kodak para filmes de duplicação de prata: <http://graphics.kodak. com/Doclmaging/BR/pt/Products/Micrographics/Microfilm/Duplicating_and_Thermal_Films/index.htm> . Acesso em: 28 fev. 2014.
} 
Quando a qualidade de reprodução for alta, os arquivos digitais também poderão servir como prova, no caso de obras furtadas e recuperadas, pois, dependendo do plano de digitalização, todas as características individuais do exemplar podem ser observadas, ajudando na identificação de livros de determinada coleção, ampliando e validando as informações também recolhidas pela análise bibliológica.

Andrade (1999) avalia os prós e contras das duas tecnologias e do sistema híbrido. Entre as vantagens do uso da microfilmagem, a autora cita que: tem sido amplamente praticada nos últimos 50 anos; é analógica; tem padrões internacionais estabelecidos, recuperação rápida, distribuição fácil e barata, segurança, durabilidade; permite a duplicação e reprodução em papel; pode ser digitalizado, entre outras. Já as desvantagens estão na reprodução monocromática, na necessidade de equipamento especial para leitura de valor alto de aquisição em comparação a um microcomputador e na impossibilidade de intervenção na imagem para melhorias.

A autora Andrade (1999) diz que as vantagens da digitalização estão na possibilidade de realização simultânea da visualização da imagem, do ajuste de parâmetros de captura e do controle de paginação, resultando em qualidade da imagem capturada, como também a garantia da legibilidade das páginas e rápida recuperação da informação. Entre as desvantagens estão o desconhecimento sobre a durabilidade dos suportes físicos da informação digital e da obsolescência dos equipamentos e programas (hardwares e softwares) utilizados. Quanto ao sistema híbrido, a autora mostra casos de sucesso como o do Banco Nacional do Desenvolvimento Econômico e Social (BNDES) e do Banco BMC, mas alerta para a necessidade de se criar uma equipe multidisciplinar para avaliação da documentação e também da organização destes documentos.

Quanto ao uso de livros raros digitalizados como fonte de informação, é possível ver na pesquisa de Gauz (2011) que a maioria dos historiadores entrevistados por ela faziam uso desse recurso, sendo muito difundido no meio, pois a indicação de pares (outros historiadores) foi dada como a forma mais usual de conhecimento de bases de livros raros digitalizados. Esse acesso significativo pode 
demonstrar que o acesso remoto ao livro raro também é usado como meio de obtenção de informação e, por isso, pode em alguns casos dispensar o acesso ao original. Este controle de acesso é defendido por Silva et al. (2006, p. 60) ao dizerem que se deve "providenciar, sempre que possível e necessário, cópias ou outro exemplar dos documentos, de forma a restringir o manuseio do original para garantir sua segurança física e sua conservação do (sic) acervo".

A volatilidade de softwares e hardwares faz com que haja dúvidas quanto à durabilidade de um arquivo digital; futuramente o mesmo pode não estar mais acessível, sendo necessária uma nova digitalização do documento impresso, o que, do ponto de vista da segurança, pode gerar a facilitação da subtração de alguma obra e, do ponto de vista da preservação, pode danificar o exemplar. Portanto, existem iniciativas que traçam ações que devem ser aplicadas para uma maior longevidade do arquivo digital, como é o caso da norma ISO 14721:2002, que estabelece o Modelo de Referência para Open Archival Information System (OAIS). Márdero Arellano (2004) mostra que, no modelo OAIS, o objeto físico e o objeto digital podem ser referenciados coletivamente, formando os objetos de dados que podem acumular informações de representação inteligíveis pela comunidade alvo, tornando-se um objeto de informação.

\begin{abstract}
O fundamento básico do modelo de dados OAIS é que se tenha "Objetos de Informação", que são conceituais compostos de um "Objeto de Dados" que é tipicamente uma seqüência de bits que compõe um dado digital - e a "Informação de Representação" que permite que este dado seja plenamente interpretado como uma informação com significado. (SAYÃO, 2010, p. 121)
\end{abstract}

Os objetos de informação podem ser definidos em quatro classes, como pode ser visto também em Márdero Arellano (2004):

- Informação de conteúdo: é o objeto primário da informação, que contém o primeiro objeto digital e informação capaz de dar significado a este objeto;

- Informação de descrição de preservação: o conjunto de informações que permitem preservar a informação de conteúdo por tempo indeterminado;

- Informação de pacote: relaciona os componentes de um pacote dentro de uma entidade identificável em uma mídia específica; 
- Informação descritiva: permite localizar, analisar, recuperar ou ordenar a informação de pacote dentro de um OAIS.

Sayão (2010) ainda detalha que estas classes de informação formam, por meio do empacotamento, pacotes de informação que estarão divididos em três grupos:

- Pacote de submissão: enviado pelo produtor da informação para o repositório;

- Pacote de armazenamento: aquele que será armazenado e preservado pelo repositório;

- Pacote de acesso: será recuperado pelo usuário em sua pesquisa.

Figura 27 - Modelo de referência OAIS

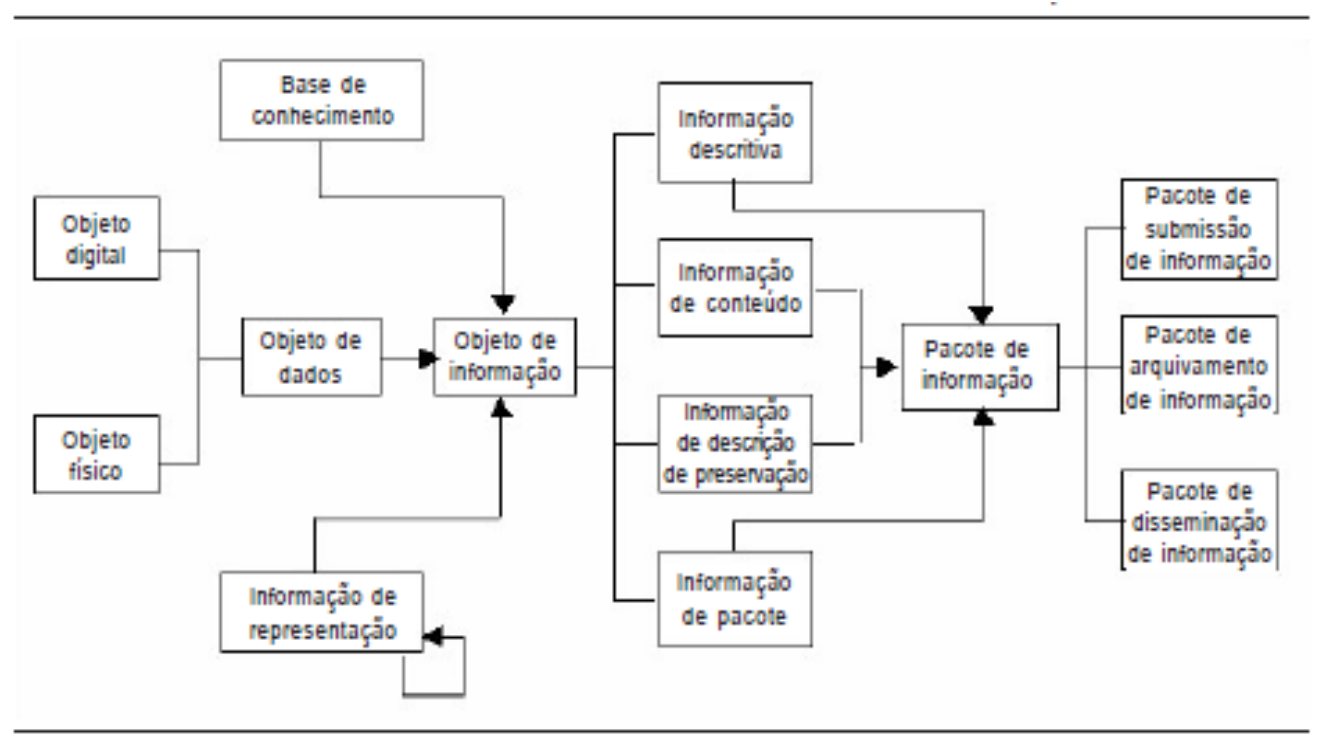

Fonte: MÁRDERO ARELLANO (2004, p. 22).

As estratégias de preservação digital têm aumentando ao longo dos anos. Ferreira (2006) elenca e explica várias destas alternativas:

- Preservação de tecnologia: basicamente é a manutenção de hardware e software utilizados originalmente na criação dos objetos digitais que deseja preservar, principalmente por meio da criação de museus tecnológicos; 
- Refrescamento: mudança de um suporte para outro mais atual (disquete, CD$\mathrm{ROM}$, disco rígido);

- Emulação: reproduzir as características de uma plataforma de hardware e/ou software, que permita que um aplicativo seja acessível em outro ambiente, em que, a princípio, seria incompatível;

- Migração/conversão: fazer a transferência periódica de um objeto digital para outro formato ou para uma tecnologia mais recente;

- Encapsulamento: consiste em preservar, juntamente com o objeto digital, toda a informação necessária e suficiente para permitir o futuro desenvolvimento de conversores, visualizadores ou emuladores.

Diante da volatilidade dos arquivos digitais, Silva et al. (2006) mostram que a digitalização de documentos deve assegurar que sejam mantidas as características importantes do documento, que sejam usados formatos padronizados, abertos, documentados e de ampla aceitação, com a utilização de esquemas de metadados padronizados que expressem a identificação, a proveniência e a contextualização dos documentos digitais. As autoras ainda dizem que para isto deve ser feito um planejamento de longo prazo para a preservação digital, tentando minimizar os efeitos da obsolescência tecnológica, com a constante atualização do processo de digitalização; e que devem ser providenciadas cópias de segurança de todo o acervo digitalizado para as preservar em local seguro.

As técnicas de digitalização e microfilmagem possuem vantagens e desvantagens, já que o objeto digital pode não ser acessado futuramente, o que não ocorrerá com o microfilme, que permite sua visualização por um longo período, mas que é condicionado a uma consulta em local específico, ao contrário do documento digital, que pode ser acessado remotamente. Portanto, é recomendado o uso das duas tecnologias, pois, do ponto de vista da segurança, ambas podem servir para impedir a consulta do original em alguns casos, atuando onde há falha na outra técnica. 


\subsubsection{Plano de emergência}

O plano de emergência serve quando todas as medidas preventivas falharem; ou seja, mesmo adotando um plano de segurança bem elaborado e empregado, com os mais modernos equipamentos de monitoração e alarme, e tendo uma equipe muito preparada, pode haver algum momento de descuido ou em que a engenhosidade do ladrão supere todas estas ações. Caso isso aconteça, algumas ações podem ser tomadas para diminuir as chances de circulação dos itens no mercado tradicional, sendo necessário agir rapidamente de forma racional e coordenada, para que aumentem as probabilidades de recuperação dos materiais roubados.

Silva et al. (2006) dizem que o plano de emergência deve conter instruções básicas para ação em caso de sinistros, com a identificação de cada recurso operacional necessário. Os autores ainda mostram como etapa essencial para execução do plano de emergência o treinamento periódico da equipe, para que esteja realmente preparada para agir no momento em que for exigida. Caso uma emergência aconteça, todos devem agir de modo que o plano seja soberano em relação às outras normas da instituição.

Ono e Moreira (2011) mostram que, para o plano de emergência ser efetivo, deve ser: simples e flexível o suficiente para acomodar as situações imprevistas, realista na avaliação dos recursos da instituição, aceito e acatado pela direção e demais funcionários e testado regularmente com exercícios de simulação, de modo que estas atitudes diminuam os efeitos colaterais do desastre, evitem o pânico na ocorrência do sinistro, respondam e recuperem rapidamente as obras, sem riscos à vida, aos recursos e serviços, e mantenha a moral e motivação dos funcionários no momento da ocorrência.

As medidas principais são: identificação rápida de quantos e quais são os materiais roubados, fazer a comunicação instantânea às autoridades competentes (direção do setor, direção da instituição, polícia local e polícia federal); entrar em contato com agentes do mercado livreiro, como antiquários, sebos, livrarias, bibliófilos e galerias de arte (no caso de gravuras); e fazer a divulgação nos veículos 
de comunicação de massa (rádio, jornal, internet e televisão) para inibir a comercialização, pois um número grande de pessoas, inclusive leigos, estará avisado do crime e poderá denunciar qualquer suspeita envolvendo os livros roubados ou furtados. O ACRL/RBMS Guidelines... (2009) diz que o responsável pela segurança deve manter contato com as autoridades legais para a rápida comunicação de casos de roubos e furtos. As diretrizes ainda mostram que, na hora de formular um plano de emergência, este deve incluir o estabelecimento de boas relações com as autoridades policiais, notificação aos bancos de dados especializados em mostrar livros roubados ou desaparecidos, notificação aos livreiros locais e regionais, transferência de itens vulneráveis a um local seguro, preparativo das avaliações após a descoberta do crime ou desaparecimento dos livros, questionamento dos funcionários sobre comportamentos suspeitos de usuários ou outras pessoas, comunicações periódicas aos funcionários sobre o andamento do caso (desde que não prejudique as investigações), comunicação à imprensa e registro interno das ações tomadas.

Brown e Patkus ([20--?]) mostram que na descoberta de um crime em andamento só se deve tomar uma ação com a certeza da ocorrência do mesmo, evitando coagir o suspeito. Para as autoras os funcionários devem conduzir o suspeito a uma sala e faze-lo esperar as autoridades e caso esse se negue alguém deve segui-lo para tentar descrever o possível carro que o suspeito tenha. Todas as ações tomadas e as informações pertinentes sobre o ocorrido devem ser anotadas imediatamente e as autoridades devem ser notificadas. Brown e Patkus ([20--?]) ainda mostram como pode haver indícios da participação de funcionários nos casos de desaparecimento de obras. As autoras mostram que há suspeitas quando frequentemente se dá falta de alguma obra, quando há tentativa em modificar registros das obras, quando alguém pede exceção às regras do local, ou mesmo quando alguém demonstra ter um estilo de vida que não corresponde aos seus recursos conhecidos. Caso haja suspeita suficiente o funcionário deve ser confrontado por ao menos duas pessoas, que permitam que o mesmo se explique, sendo necessário afastar a pessoa temporariamente do serviço até que sejam apurados os fatos. 
A comunicação entre as diversas entidades interessadas nos casos de roubo ou furto é imprescindível, pois também é considerada crime a receptação de bens roubados. Neste sentido, no Reino Unido, a Antiquarian Booksellers Association (ABA) e o Chartered Institute of Library and Information Professionals (CILIP) criaram o Theft of Books and Manuscripts from Libraries: an advisory code of conduct for booksellers and librarians para que os livreiros possam seguir no caso de desconfiança de que tenham em mãos um livro roubado ou furtado. Os principais artigos se referem à obrigação do livreiro em identificar se há documentação do livro oferecido à venda; e, caso haja desconfiança de roubo ou furto do item, deve ser feita busca em banco de dados sobre obras desaparecidas e contato direto com a biblioteca que constar nas marcas de propriedade, se for o caso. Existe também, no código de conduta, uma sugestão para o acordo em caso de compra, comprovadamente de boa fé, de livros roubados ou furtados, com a provável devolução de metade dos custos ao livreiro. No entanto, o código está baseado no pressuposto de que todas as obras de uma biblioteca contêm marca de propriedade, o que não acontece em muitas coleções de livros raros.

No Brasil, o Instituto do Patrimônio Histórico e Artístico Nacional (Iphan), em parceria com a Polícia Federal e a Interpol, criou um banco de dados online, onde são armazenadas informações sobre bens culturais procurados; contudo, mesmo com o histórico de vários roubos e furtos de livros, um único título é listado neste site: o livro Toros, com ilustrações de Pablo Picasso, roubado em 2006 do Museu Chácara do Céu, no Rio de Janeiro. Isto ocorre porque o Banco de Dados de Consulta a Bens Culturais Procurados só mantém registros de bens tombados pelo Iphan. No entanto, eles colocam nota em seu site sobre casos que não possuem bens tombados, como aconteceu com o livro Rerum per octennium in Brasilia... do Instituito Geográfico e Histórico da Bahia ${ }^{29}$. A Interpol também mantém o Stolen Works of Art Database, com notícias de roubos e furtos de bens culturais em todo o mundo, mas esta base de dados só é acessível por meio de registro e autorização da instituição. O The Art Loss Register possui o maior banco de dados privado sobre

\footnotetext{
29 Notícia sobre o desaparecimento do Rerum per octennium in Brasilia... disponível em: $<$ http://portal.iphan.gov.br/portal/montarDetalheConteudo.do?id=17225\&sigla=Noticia\&retorno=detalh eNoticia>. Acesso em: 04 ago. 2014.
} 
desaparecimento de bens culturais, mas, por ser privado, é necessário o pagamento de taxas para acesso e registro.

Para o ACRL/RBMS Guidelines... (2009), a instituição deve tomar ainda como ações posteriores ao crime a reunião de provas, com descrição detalhada dos exemplares desaparecidos ou roubados; o levantamento de quaisquer registros de segurança considerados relevantes e dos acessos não autorizados às áreas restritas; e a elaboração de relatórios sobre perdas ou adulterações nos registros de catalogação ou de circulação. As diretrizes ainda indicam que a instituição deve participar na acusação dos criminosos fazendo uma declaração que mostre a gravidade do crime, ao dano ao registro cultural, e seu impacto sobre a instituição e seus usuários.

\subsubsection{Perfil do profissional que cuida de livros raros}

O profissional da informação que cuida de acervos de livros raros, para poder elaborar e executar uma proposta de segurança para a coleção, deve dominar algumas técnicas apresentadas ao longo deste trabalho. É preciso que saiba sobre a história do livro, para poder efetuar uma análise bibliológica e uma pesquisa bibliográfica. Também é preciso saber quais fontes de informação são relevantes para o reconhecimento de um título.

O bibliotecário de referência de obras raras deve possuir um nível de
qualificação ainda maior, uma vez que seu público é, quase sempre, muito
especializado, e com grande conhecimento do assunto que pesquisa. [...] A
biblioteca deve, assim, mostrar aos seus leitores a necessidade de cuidar e
proteger os livros raros que, na maioria, não podem ser repostos. [...] A
chefia de uma coleção de livros raros deve estar atenta a equilibrar suas
funções básicas: a de colocar os documentos à disposição do leitor, sem
descuidar da segurança. [...] O usuário deve ser orientado sobre a coleção,
sendo informado de que forma manuseá-la adequadamente, antes de
solicitar o livro. (GAUZ, 1994, p. 24)

O conhecimento sobre gerenciamento de risco pode ajudar na prevenção contra o roubo de obras. Para Reifschneider (2008), raramente os bibliotecários recebem capacitação adequada para a execução de suas tarefas, como seleção e preservação. O autor ainda mostra que, enquanto no Brasil é comum verificar profissionais sem instrução e recém-formados na curadoria de livros raros, nos 
Estados Unidos o perfil exigido para o gestor deste tipo de acervo inclui uma formação com mestrado e, em alguns casos, com doutorado, com conhecimento de línguas como o Latim e do mercado livreiro. Lá frequentemente é possível ver professores de Biblioteconomia no comando deste tipo de Seção.

Através da história, nem todos os países tem (sic) contado com uma instituição especializada em formar bibliotecários de obras raras; na prática, a maioria dos encarregados tem vindo de outras áreas ou realizam seu trabalho em conjunto com outros especialistas. (MÁRDERO ARELLANO, 1998, p. 37)

O profissional que lida com livros raros tem que estar preparado para agir em todos os contextos apresentados, pois ele é quem sabe das necessidades de segurança do setor e por isso deve estar envolvido na implantação de um plano de segurança que seja efetivo para a realidade de sua instituição, sabendo também lidar com as ferramentas tecnológicas que podem dar suporte à segurança do acervo.

\subsection{Legislação de proteção aos livros raros}

O presente trabalho parte do pressuposto de que um livro raro é parte integrante do patrimônio cultural de uma nação, principalmente no Brasil, levando em consideração a definição legal da Constituição Federal brasileira, no artigo 216º nos incisos I a $V$ que diz:

Constituem patrimônio cultural brasileiro os bens de natureza material e imaterial, tomados individualmente ou em conjunto, portadores de referência à identidade, à ação, à memória dos diferentes grupos formadores da sociedade brasileira, nos quais se incluem:

I - as formas de expressão;

II - os modos de criar, fazer e viver;

III - as criações científicas, artísticas e tecnológicas;

IV - as obras, objetos, documentos, edificações e demais espaços destinados às manifestações artístico-culturais;

$\mathrm{V}$ - os conjuntos urbanos e sítios de valor histórico, paisagístico, artístico, arqueológico, paleontológico, ecológico e científico.

O livro é contemplado principalmente nos incisos III e IV, ou mesmo nos materiais de interesse público e valor bibliográfico que tratam o Decreto-Lei n. 25, de 30 de novembro de 1937, no seu artigo 1º ao dizer que: 
Constitue o patrimônio histórico e artístico nacional o conjunto dos bens móveis e imóveis existentes no país e cuja conservação seja de interêsse público, quer por sua vinculação a fatos memoráveis da história do Brasil, quer por seu excepcional valor arqueológico ou etnográfico, bibliográfico ou artístico.

Neste mesmo decreto-lei, o livro raro é citado diretamente como um dos itens resguardados no artigo $26^{\circ}$, ao estabelecer normas aos negociantes de antiguidades:

Os negociantes de antiguidades, de obras de arte de qualquer natureza, de manuscritos e livros antigos ou raros são obrigados a um registro especial no Serviço do Patrimônio Histórico e Artístico Nacional, cumprindo-lhes outrossim apresentar semestralmente ao mesmo relações completas das coisas históricas e artísticas que possuírem.

A definição de bens culturais pela Carta de Paris, aprovada na Convenção Relativa às medidas a serem adotadas para proibir e impedir a importação, exportação e transferência de propriedades ilícitas dos bens culturais, pela Unesco, de 12 de outubro a 14 de novembro de 1970 e posteriormente adotada pelo Brasil pelo Decreto n. 72.312 , de 31 de maio de 1973, traz o livro raro citado explicitamente no seu artigo 1, alíneas "a" e "h":

Para os fins da presente Convenção, a expressão "bens culturais" significa quaisquer bens que, por motivos religiosos ou profanos, tenham sido expressamente designados por cada Estado como de importância para a arqueologia, a pré-história, a história, a literatura, a arte ou a ciência e que pertençam às seguintes categorias:

a) as coleções e exemplares raros de zoologia, botânica, mineralogia e anatomia, e objetos de interesse paleontológico; [...]

h) manuscritos raros e incunábulos, livros, documentos e publicações antigos de interesse especial (histórico, artístico, científico, literário etc.), isolados ou em coleções [...]

Dentro desta visão, sem entrar em discussões maiores, é possível dizer que um livro raro, portanto, é protegido pelas leis que tratam do patrimônio cultural de forma abrangente e por aquelas que não distinguem os objetos a que se referem.

A Constituição Federal brasileira traz a responsabilidade da proteção do patrimônio cultural para o Estado ao dizer no artigo 23을 inciso III, que é competência comum da União, dos Estados, do Distrito Federal e dos Municípios "proteger os documentos, as obras e outros bens de valor histórico, artístico e cultural, os monumentos, as paisagens naturais notáveis e os sítios arqueológicos"; ao atribuir a

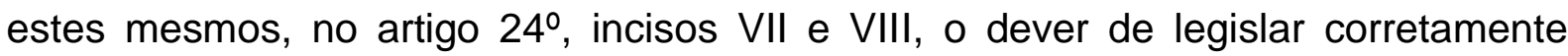


sobre proteção ao patrimônio histórico, cultural, artístico, turístico e paisagístico, além de legislar sobre responsabilidade por dano ao meio ambiente, ao consumidor, a bens e direitos de valor artístico, estético, histórico, turístico e paisagístico; ou seja, os governantes precisam estabelecer medidas de controle e proteção destes itens, mesmo que estejam nas mãos de pessoas físicas ou de direito privado.

No $\S 1^{\circ}$ do artigo $216^{\circ}$ são exemplificadas ferramentas de auxílio à proteção do patrimônio: "o Poder Público, com a colaboração da comunidade, promoverá e protegerá o patrimônio cultural brasileiro, por meio de inventários, registros, vigilância, tombamento e desapropriação, e de outras formas de acautelamento e preservação".

O primeiro instrumento legal de proteção ao patrimônio cultural vigente até hoje foi o já citado Decreto-lei n. 25, de 30 de novembro de 1935, que, além de delimitar seu próprio raio de ação e de definir o seu objeto, o patrimônio cultural, dispõe sobre a ferramenta prevista constitucionalmente - o tombamento estabelecendo os 4 livros de tombos (Arqueológico, etnográfico e paisagístico; Histórico; das Belas Artes; e das Artes aplicadas), além de dar os efeitos desta ação.

O tombamento pode ocorrer a materiais que são de propriedade pública ou privada e o benefício desta prática é aumentar o controle, a proteção e a preservação sobre o bem tombado, que passa a ser "considerado parte integrante do patrimônio histórico e artístico nacional" como determina o decreto-lei. A partir do tombamento, qualquer deslocamento ou transferência de propriedade do bem cultural deve ser avisado ao Iphan, assim como deverão ser avisadas quaisquer necessidades de obra, conservação ou restauração, que devem ser aprovadas por este órgão; além de ficarem impedidas a destruição, a demolição e a mutilação do item tombado. O Iphan ainda poderá exercer vigilância sobre o bem tombado sempre que julgar conveniente sem a criação de obstáculos do responsável. Também é previsto no decreto-lei que as obras de conservação ou reparação da coisa tombada podem ser feitas, a expensas da união, desde que o proprietário não tenha recursos para tal ou mesmo por iniciativa própria do Iphan. 
A instauração do processo de tombamento é regulamentada pela Portaria no 11 , de 11 de setembro de 1986, do Iphan. No artigo $2^{\circ}$ é dito que "toda pessoa física ou jurídica será parte legítima para provocar, mediante proposta, a instauração do processo de tombamento". No caso de bens móveis é determinado no artigo $4^{\circ}, \S 2^{\circ}$ que:

\begin{abstract}
No caso de a proposta de tombamento se referir a bem ou bens móveis, a instrução do pedido constará de descrição pormenorizada do objeto, se tratar de peça única ou da relação detalhada de peças componentes da coleção, listadas uma a uma, mencionando-se o material empregado, as dimensões de cada unidade e outras características que as individualiza, assim como de informações precisas sobre a localização, o proprietário e/ou responsável pela guarda do(s) objeto(s) e seu estado de conservação, acrescidas de documentação fotográfica e análise do valor desses bens para o patrimônio cultural do País.
\end{abstract}

No contexto dos livros raros, o tombamento ainda não é uma ferramenta efetiva de proteção ao acervo. Murguia e Yassuda (2007), ao estudarem este aspecto, verificaram que o tombamento de três bibliotecas ocorreu em decorrência do edifício da instituição e não pelos livros, que não são citados em momento algum nos processos. Dois dos três casos analisados teriam posteriormente seus acervos tombados, por se tratarem de ordens religiosas que foram abraçadas pela Resolução do Conselho Consultivo do Iphan, de 13 de agosto de 1985, referente ao processo administrativo n. 13/85, que tombou também os acervos referentes às igrejas, mosteiros, conventos ou capelas tombadas individualmente, como mostram os autores. Portanto, os documentos protegidos pelo tombamento são os livros que pertencem às igrejas católicas que são tombadas individualmente e os documentos detentores de reminiscências históricas dos antigos quilombos, estes últimos em determinação do artigo $216^{\circ}$, no $\S 5^{\circ}$ da Constituição Federal. O tombamento da Biblioteca Nacional, que é o outro caso estudado por Murguia e Yassuda (2007), não inclui seu acervo, mas apenas seu prédio ${ }^{30}$.

Outra ferramenta de reconhecimento da importância de determinada coleção ou documento é o Projeto Memória do Mundo, que tem como organizadora mundial a Unesco e que, no Brasil, sua função e estruturação diretiva são regulamentadas

\footnotetext{
${ }^{30}$ No ítem 4.3.6 Análise das entrevistas, deste trabalho, é possível ver notícias sobre outros casos de tombamento de acervos bibliográficos e o motivo da baixa quantidade de livros raros tombados.
} 
pela Portaria n. 61, de 31 de outubro de 2007, e Portaria n. 84, de 01 de outubro de 2013. Este projeto tem como missão "aumentar a consciência e a proteção do patrimônio documental mundial e conseguir sua acessibilidade universal e permanente" (EDMONDSON, 2002, p. 9). Este projeto classifica uma coleção ou documento como relevante para a humanidade, de modo a incentivar a própria instituição a divulgá-lo e preservá-lo, além de estimular as ajudas externas com o mesmo propósito, desde que os documentos se enquadrem nos critérios previstos no item 4.2 das Diretrizes para a Salvaguarda do Patrimônio Documental, levando em conta a autenticidade, unicidade e significância mundial do documento ou coleção (EDMONDSON, 2002).

O Decreto-lei n. 25, de 30 de novembro de 1935, ainda traz o Direito de Preferência, que prevê que, na alienação onerosa de bem tombado, tal item deve previamente ser oferecido por igual valor à União, ao Estado ou ao Município (nesta ordem) em que se encontra. No caso de livros raros, dá possibilidade, na hipótese de acervos particulares tombados, que os mesmos venham a incorporar e aprimorar as coleções das bibliotecas submetidas ao regime do direito público.

Nas disposições gerais do Decreto-lei n. 25, há previsão de acordos de cooperação providos pelo Poder Executivo entre a União e os Estados, e entre o Iphan e autoridades eclesiásticas e instituições científicas, históricas ou artísticas entre outras, para proteção ao patrimônio histórico e artístico nacional. Além disso, traz a determinação de que os negociantes de antiguidades (os livros antigos, raros e os manuscritos são citados explicitamente) têm de manter cadastro junto ao Iphan, apresentando semestralmente relação das obras que possuírem. Também os leiloeiros e comerciantes, na possível venda destes objetos, têm que passar uma relação ao Iphan. Nestes dois últimos casos, dos negociantes e leiloeiros, os objetos a que se refere o decreto-lei não precisam necessariamente estar tombados.

Uma ferramenta legislativa importante na tentativa de combate à comercialização ilegal de bens patrimoniais é a Instrução Normativa 01, de 11 de junho de 2007, do Iphan. Tal Instrução Normativa dispõe de forma mais detalhada, sobre matéria contemplada nos artigos 26 e 27 do Decreto-lei n. 25, a respeito do processo de cadastro de negociantes de bens culturais junto ao Iphan e as venda 
em leilões. No que tange aos livros raros, são apontadas no dispositivo legal as características que o livro deve ter para que o negociante ou leiloeiro seja obrigado a informar ao Iphan sobre sua comercialização:

Art. $3^{\circ}$. Estão sujeitas ao cadastro especial no IPHAN as pessoas que comercializem os seguintes bens culturais:

[...]

IX - Os livros antigos ou raros, desse modo consagrados na literatura especializada, ou que tenham valor literário, histórico ou cultural permanente:

a) a Coleção Brasiliana: livros sobre o Brasil - no todo ou em parte, impressos ou gravados desde o século XVI até o final do século XIX (1900 inclusive), e os livros de autores brasileiros impressos ou gravados no estrangeiro até 1808;

b) a Coleção Brasiliense: livros impressos no Brasil, de 1808 até nossos dias, que tenham valor bibliofílico: edições da tipografia régia, primeiras edições por unidades federativas, edições príncipes, primitivas ou originais e edições em vida - literárias, técnicas e científicas; edições fora de mercado, produzidas por subscrição; edições de artista;

c) Os incunábulos, pós-incunábulos e outras edições impressas e gravadas, célebres ou celebrizadas, de evidenciado interesse para o Brasil, impressas artesanalmente nos séculos XV a XVIII (1800 inclusive), em qualquer lugar; (...)

A Instrução Normativa 01, portanto, pode ajudar, por meio da lista fornecida pelo negociante de livros raros, a identificar algum exemplar que seja objeto de roubo ou furto. A Instrução Normativa ainda prevê os dados mínimos da obra, que o comerciante deve informar:

Art. 5․ No ato da inscrição no cadastro especial, a pessoa deverá apresentar a relação descritiva dos objetos disponíveis para comercialização, em estoque ou reserva, contendo as informações mínimas abaixo especificadas, e também na forma do Anexo I, que integra esta Instrução Normativa:

[...]

III - em caso de livros antigos ou raros: autor, título, edição, imprensa (local, editora, data), extensão (total de volumes/tomos/partes/páginas/folhas), dimensão (altura, tomada pela lombada, em centímetros), informação adicional que personalize o exemplar; consignação ou propriedade.

O inventário também está previsto no artigo 216ํㅡㄴ no $\S 1^{\circ}$, como ferramenta de proteção ao patrimônio cultural. Miranda (2008, p. 293) diz que o inventário:

[...] consiste na identificação e registro por meio de pesquisa e levantamento das características e particularidades de determinado bem, adotando-se, para sua execução, critérios técnicos objetivos e fundamentados de natureza histórica, artística, arquitetônica, sociológica, paisagística e antropológica, entre outros. 
No entanto, não existem normatizações infraconstitucionais que explicitem seus efeitos jurídicos. No caso específico de obras raras, é possível ver que essa ferramenta de proteção é usualmente aplicada pelas próprias instituições guardiãs do acervo, como, por exemplo, o inventário da Coleção de periódicos raros da Biblioteca de Ciências Biomédicas da Fundação Oswaldo Cruz - RJ, começado em setembro de 2007 e tema do trabalho de Dias, Silva e Rodrigues (2008); ou a Coleção da Congregação do Oratório de São Filipe Néri de Pernambuco Oratorianos, realizado entre 2004 e 2006, tema do trabalho de Amazonas (2008).

Vários encontros foram realizados, ao longo dos anos, em todo o mundo, para discutir e tentar trazer soluções aos problemas relacionados à preservação do patrimônio cultural. Exemplos de documentos gerados por estas reuniões são as Cartas de Nova Deli e Paris, em 1956 e 1970, respectivamente, e o texto da Convenção Unidroit em 1995, entre outros. Destaque para as Cartas de Paris promulgadas em 1970 e para a Convenção Unidroit que seriam assinadas como tratado internacional, no qual o Brasil fez valer os Decretos n. 72.312, de 31 de maio de 1973 , e n. 3.166, de 14 de setembro de 1999. Ambas as convenções tratam sobre a exportação e importação ilícita de bens culturais, com a Carta de Paris estabelecendo metas de combate a estas práticas a serem cumpridas pelos países, e a Convenção Unidroit trazendo regras mais claras sobre como devem se comportar os países assinantes no pedido de reintegração e na devolução das obras.

A Carta de Paris, como dito, traça metas a serem cumpridas pelas nações, como a criação de uma legislação, prevista no artigo $5^{\circ}$ alínea "a" onde os EstadosPartes têm que:

[...] contribuir para a preparação de projetos de leis e regulamentos destinados a assegurar a proteção ao patrimônio cultural, e particularmente a prevenção da importação, exportação e transferência de propriedade ilícitas de bens culturais importantes; [...]

A Carta de Paris ainda prevê, entre outras coisas, que os Estados se comprometam em manter um inventário atualizado de seu patrimônio, em criar museus, arquivos, bibliotecas, entre outras instituições que visem a assegurar a preservação e a apresentação de seus bens culturais, em realizar medidas 
educacionais de conscientização sobre o respeito ao patrimônio cultural e em colaborar para que sua nação não favoreça a importação de bens culturais ilícitos, nem sequer tenha os seus objetos exportados ilegalmente.

A Convenção Unidroit já fixa regras de como irão se comportar os Estados ao requererem seus bens culturais que se encontrem ilegalmente em outro Estado que também tenha assinado o tratado internacional. Portanto, a Unidroit estabelece prazos e meios para a entrada dos pedidos de repatriação das obras, com previsão de prescrição da ação, além de trazer os direitos do possuidor do objeto, desde que este não tenha agido de má fé na sua aquisição.

O principal instrumento legal que tem como foco específico a proteção de livros raros é a Lei n. 5.471 de 9 de julho de 1968, que dispõe sobre a exportação de livros antigos e conjuntos bibliográficos brasileiros. Esta lei proíbe a exportação de bibliotecas e acervos documentais constituídos de obras brasileiras ou sobre o Brasil, editadas entre os séculos XVI e XIX, coleções de periódicos publicados há mais de dez anos e cópias antigas de partituras musicais. Há previsão de saída temporária destes materiais, desde que seja de interesse cultural. Portanto, a lei inclui os periódicos e as partituras no mesmo conjunto que trata de livros raros, sem, no entanto, trazer maiores detalhes dos periódicos e das partituras protegidas por ela.

O Decreto n. 65.347 de 13 de outubro de 1969 veio regulamentar a Lei $n$. 5.471. Diferente da lei que regulamenta, o decreto prevê a exportação de livros deste período, conforme seu artigo 4ํㅜ을

A exportação de livros antigos, brasileiros, ou sôbre o Brasil, editados nos séculos XVI a XIX (até 1899), dependerá de comprovação:

a) de não provirem de conjuntos bibliográficos cuja exportação é proibida;

b) de se haver pronunciado favoravelmente o Conselho Federal de Cultura, ou, por delegação dêste, o Conselho Estadual de Cultura competente.

No entanto, nem o Decreto n. 65.347 nem a Lei n. 5.471 dão expediente sobre quais conjuntos bibliográficos estão liberados ou proibidos para exportação, dando margem de interpretação às autoridades competentes. No caso do decreto e lei citados, o órgão competente para análise dos pedidos de exportação é o Conselho Federal de Cultura, que não foi previsto na estruturação do Ministério da 
Cultura, demonstrando a necessidade de novas leis que regulamentem a venda e exportação de livros raros.

A portaria n. 262, de 14 de agosto de 1992, do então Instituto Brasileiro de Patrimônio Cultural (IBPC), hoje Iphan, veio normalizar os processos de pedidos de saída de obras de arte e outros bens culturais. Esta portaria estabelece, portanto, o prazo máximo de 6 meses para permanência das obras no exterior, ou de 2 anos para o caso de exposições itinerantes. A portaria também aponta toda a documentação exigida para a solicitação da saída de obras do país, além de colocar o proprietário das obras como responsável por sua integridade e cumprimento das normas da portaria. Ainda no artigo $14^{\circ}$ a portaria prevê penalidades para o seu descumprimento:

\footnotetext{
Tentada, a não ser nas hipóteses previstas nesta portaria, a saída do país das obras a que se refere o "caput" do art. $1^{\circ}$, serão as mesmas sequestradas pela união ou pelo estado na qual se encontrarem.

$\S 1^{\circ}$ - apurada a responsabilidade do proprietário, ser-lhe-á imposta a multa de cinquenta por cento do valor das obras, que permanecerão sequestradas em garantia até o final do processo administrativo e pagamento da multa. $\S 2^{\circ}$ - no caso de reincidência, a multa será elevada ao dobro.

$\S 3^{\circ}$ - a aplicação das penalidades ora previstas não exclui aquelas cominadas no Código Penal para o crime de contrabando ou descaminho.
}

Os principais crimes ligados à aquisição e comercialização ilícita de obras são o roubo e o furto. No entanto, o Código Penal brasileiro traz outras modalidades criminosas que se associam direta ou indiretamente a essas duas atividades ilegais contribuindo para o sumiço de bens culturais, caracterizados no código como Crimes contra o patrimônio. Como o foco deste trabalho é análise do roubo e furto de livros raros, os outros crimes a serem mencionados, como falsidade ideológica, contrabando ou descaminho, receptação, formação de quadrilha, peculato e dano em coisa de valor artístico, arqueológico ou histórico serão analisados na relação que têm com os outros dois casos e não em situações isoladas onde as práticas do roubo e furto de livros raros nada contribuíram para sua execução.

No Código Penal, a diferença entre roubo e furto se dá mediante o uso ou não da violência; no primeiro caso, a denominação jurídica é roubo e, no não uso de violência, é furto. Abaixo segue quadro que mostra a pena prevista para cada crime que possivelmente se relaciona a roubo ou furto de obra rara. 
Quadro 2 - Penalidades para roubo, furto e crimes relacionados

\begin{tabular}{|c|c|c|}
\hline Crime & Artigo & Penalidade \\
\hline Furto & 155 & $\begin{array}{l}\text { Pena - reclusão, de um a quatro anos, e multa. } \\
\S 1^{\circ} \text { - A pena aumenta-se de um terço, se o crime } \\
\text { é praticado durante o repouso noturno. } \\
\S 2^{\circ}-\text { Se o criminoso é primário, e é de pequeno } \\
\text { valor a coisa furtada, o juiz pode substituir a pena } \\
\text { de reclusão pela de detenção, diminuí-la de um a } \\
\text { dois terços, ou aplicar somente a pena de multa. }\end{array}$ \\
\hline Furto qualificado & $\begin{array}{l}155 \\
\S 4^{\circ}\end{array}$ & $\begin{array}{l}\text { Pena - reclusão de dois a oito anos, e multa, se o } \\
\text { crime é cometido: } \\
\text { I - com destruição ou rompimento de obstáculo à } \\
\text { subtração da coisa; } \\
\text { II - com abuso de confiança, ou mediante fraude, } \\
\text { escalada ou destreza; } \\
\text { III - com emprego de chave falsa; } \\
\text { IV - mediante concurso de duas ou mais pessoas. }\end{array}$ \\
\hline Roubo & 157 & $\begin{array}{l}\text { Pena - reclusão, de quatro a dez anos, e multa. } \\
\S 2^{\circ} \text { - A pena aumenta-se de um terço até } \\
\text { metade: } \\
\text { I - se a violência ou ameaça é exercida com } \\
\text { emprego de arma; } \\
\text { II - se há o concurso de duas ou mais pessoas; } \\
\text { III - se a vítima está em serviço de transporte de } \\
\text { valores e o agente conhece tal circunstância. } \\
\text { V - se o agente mantém a vítima em seu poder, } \\
\text { restringindo sua liberdade. }\end{array}$ \\
\hline $\begin{array}{l}\text { Dano em coisa de valor } \\
\text { artístico, arqueológico ou } \\
\text { histórico }\end{array}$ & 165 & $\begin{array}{l}\text { Pena - detenção, de seis meses a dois anos, e } \\
\text { multa. }\end{array}$ \\
\hline Receptação & 180 & Pena - reclusão, de um a quatro anos, e multa. \\
\hline Receptação qualificada & $\begin{array}{l}180 \\
\S 10\end{array}$ & Pena - reclusão, de três a oito anos, e multa. \\
\hline Associação Criminosa & 288 & $\begin{array}{l}\text { Pena - reclusão, de um a três anos. } \\
\text { Parágrafo único - A pena aplica-se em dobro, se a } \\
\text { quadrilha ou bando é armado. }\end{array}$ \\
\hline Falsidade ideológica & 299 & $\begin{array}{l}\text { Pena - reclusão, de um a cinco anos, e multa, se } \\
\text { o documento é público, e reclusão de um a três } \\
\text { anos, e multa, se o documento é particular. }\end{array}$ \\
\hline $\begin{array}{l}\text { Contrabando ou } \\
\text { descaminho }\end{array}$ & 334 & $\begin{array}{l}\text { Pena - reclusão, de um a quatro anos. } \\
\S 3^{\circ} \text { - A pena aplica-se em dobro, se o crime de } \\
\text { contrabando ou descaminho é praticado em } \\
\text { transporte aéreo. }\end{array}$ \\
\hline
\end{tabular}

Fonte: Do autor.

É possível verificar, nos itens 2.3 e 2.4 deste trabalho, a relação que todos os crimes aqui citados têm com roubo e furto, inclusive no que corresponde ao acervo raro. Por exemplo, o furto aplica-se principalmente àqueles casos em que a 
apropriação indevida de um livro raro foi descoberta em levantamento dos exemplares ou em pedido de pesquisa do usuário, enquanto o furto qualificado seria o caso onde há invasão e/ou arrombamento do local de guarda. O caso do crime em que o ladrão faz uso de arma se enquadra nos agravantes dos casos de roubo, inclusive sendo também um agravante a participação de duas ou mais pessoas neste ato.

Os danos em coisa de valor artístico, arqueológico e histórico geralmente se associam ao roubo e furto, quando há prejuízo aos exemplares no cuidado inadequado em armazená-los, ou ainda propositalmente para a exclusão de marcas de propriedade que possam denunciar as obras como objeto ilícito. No entanto, este dispositivo presente no art. 165 do Código Penal brasileiro prevê que o material seja tombado. Caso este não seja, a previsão legal está no art. 163 sobre Dano ou no art. 164, que trata sobre Dano qualificado.

A receptação, segundo o artigo 180 do Código Penal, consiste em "Adquirir, receber, transportar, conduzir ou ocultar, em proveito próprio ou alheio, coisa que sabe ser produto de crime, ou influir para que terceiro, de boa-fé, a adquira (sic), receba ou oculte", ou seja, é a ação que vem depois dos crimes de roubo e furto, na tentativa de adquirir para si uma obra que sabe ser roubada, ou de comercializá-la para outro, tornando-se, neste caso, receptação qualificada.

Não obstante, a existência da materialidade de um crime antecedente, (sic)
é requisito imprescindível para a consumação da receptação, seja furto,
roubo ou algum outro que não seja necessariamente mencionado no rol dos
crimes patrimoniais. (COSTA; ROCHA, 2007, p. 270)

Alguns roubos exigem planejamento elaborado para sua execução, pois, apesar do ganho monetário ser maior, os riscos também o são. Para estes crimes provavelmente terão mais de três pessoas associadas para sua realização, tornando-se assim uma formação de quadrilha, apesar de Salvo (2010, p. 9) dizer que a maioria dos roubos é de arrombamentos residenciais em busca de objetos de valor mais baixo, em que "os ladrões são geralmente desorganizados e frequentemente roubam devido a (sic) oportunidade" (Salvo, 2010, p. 8). O autor também afirma que "há relatos de quadrilhas especializadas que estudam e 
planejam a ação e que conhecem o valor monetário e artístico das obras. Estes criminosos investem na ação e arcam com um custo mais elevado que os demais".

A falsidade ideológica associa-se a roubo e furto de livros raros principalmente quando o ladrão se passa por usuário normal do acervo. Contudo, os dados pessoais fornecidos por ele para registro de sua consulta à coleção não são verdadeiros. O Código Penal, em seu artigo 299, diz que este crime está relacionado a:

Omitir, em documento público ou particular, declaração que dele devia constar, ou nele inserir ou fazer inserir declaração falsa ou diversa da que devia ser escrita, com o fim de prejudicar direito, criar obrigação ou alterar a verdade sobre fato juridicamente relevante.

A pena pode ser maior caso este crime ocorra em documento público.

O contrabando e o descaminho correspondem à importação ou exportação ilícita das obras, como mostram Costa e Rocha (2007, p. 277):

\footnotetext{
Frise-se que na hipótese de venda ilícita de obras culturais estrangeiras, introduzidas clandestinamente no país, importadas ou eventualmente exportadas, o agente não responderá pelo delito de receptação qualificada, mas sim pelo crime de contrabando ou descaminho, tipificado no artigo 334, $\S 1^{\circ}$, alínea "c", do Código Penal, cuja competência é exclusiva da Polícia Federal, conforme o disposto no artigo 144, §1ํㅡ, inciso II, da Constituição Federal.
}

Apesar de toda a legislação citada que visa a diminuir as ações de roubo, furto ou crimes relacionados e apesar do livro raro estar certamente relacionado a essa proteção, Ponte (2006, p. 9) mostra que o Direito Penal, na observação da proteção ao patrimônio cultural, está em consonância com a intervenção mínima, que, segundo o autor, faz com que "a resposta penal destinada aos autores de tais crimes que atingem a história e cultura de um povo [seja] extremamente tênue, isto quando há punição, pois, em boa parte das vezes, são adotadas medidas despenalizadoras".

\subsection{Teorias da criminalidade}

Existem várias perspectivas científicas sobre o crime, que se diferenciam principalmente sobre o que consideram determinante para que haja uma ação 
criminosa, divididas por meio de sua abordagem, que leva em consideração principalmente as patologias individuais, a sociedade ou os fatores econômicos.

Mendes (1997) mostra a diferença entre a Escola Clássica e a Escola Positivista: a primeira mostra o crime como uma atitude racional, baseada no paradoxo prazer-sofrimento, enquanto a segunda trata o crime como algo não opcional, pois cada um nasce com um potencial para o crime. Para a autora, a Escola Clássica é desenvolvida por Cesare Beccaria que mostra que as pessoas buscam maximizar o prazer e minimizar o sofrimento, e que por isso as penas devem ser fixas e correspondentes a cada crime, para sobrepor o prazer e o ganho proveniente da atividade ilegal, induzindo que as pessoas façam o bem, pois, para a Escola Clássica, o mal também proporciona prazer, sendo a busca pela felicidade uma escolha racional, enquanto a Escola Positivista tem o foco nas patologias individuais, onde a criminalidade seria oriunda de uma transferência hereditária de comportamento, ou seja, uma pré-disposição para o crime, que seria desencadeada por uma pressão social sobre o indivíduo ou disfunção biológica e/ou psicológica. A Escola Positivista, portanto, tentou mostrar a influência fisiológica ou biológica, psicológica e social sobre o criminoso.

A perspectiva fisiológica ou biológica defendeu que as características físicas ou anatômicas do indivíduo poderiam indicar uma pré-disposição para a criminalidade. Mendes (1997) mostra que não há uma divisão clara entre a perspectiva biológica e a psicológica, pois muitos trabalhos buscam identificar as relações entre a hereditariedade e fatores genéticos com os distúrbios neurológicos ou disfunções da personalidade que levassem o indivíduo a se tornar um infrator da lei.

As teorias sociais retiram o foco do indivíduo e suas patologias e o transfere para a sociedade, ou seja, seus estudos se baseiam principalmente na influência que as interações sociais têm sobre a decisão individual de cometer um crime.

Um exemplo de teoria da criminalidade com foco na sociedade é a Teoria da Desorganização social, que: 
[...] defende que as taxas de delinquência encontradas naquela cidade [Chicago] mostravam-se maiores onde havia, comparativamente, alto teor de desorganização social. Argumentavam, a partir daí, que a delinquência era um problema de patologia social (OLIVEIRA, 2008, p. 47).

Há ainda a Teoria da Associação Diferencial, que foca no modo como o comportamento individual é influenciado pelas experiências pessoais. Esta teoria diz que "os jovens tendem a desenvolver atitudes e habilidades necessárias para se tornarem descumpridores de uma norma estabelecida, associando (sic) com pessoas que são 'portadores' (sic) de comportamentos desviantes” (ARAÚJO, 2011, p. 61).

A Teoria do Controle Social, diferentemente das outras teorias da criminalidade, não foca nas motivações de cometer um ato criminoso, mas nos fatores que determinam que um indivíduo não caminhe para a criminalidade. Para Cerqueira e Lobão (2004), quanto maior o envolvimento do cidadão com a sociedade e seu grau de aceitação das normas e valores vigentes, menores seriam as chances de cometer um crime.

A Teoria do Autocontrole diz que a diferença entre uma pessoa que tem conduta desviante ou vícios para uma que não tem é que a primeira não desenvolveu ferramentas psicológicas entre a infância e a pré-adolescência, trazendo a culpa para a criação do indivíduo, como mostram Cerqueira e Lobão (2004). Os autores ainda mencionam as teorias da Anomia e a Interacional; a primeira diz que a motivação para o crime está nas frustações do indivíduo na não realização de seus anseios; já a Teoria Interacional mostra que a delinquência é resultado de um processo dinâmico, consequência de uma variedade de relações recíprocas desenvolvidas ao logo do tempo.

A Economia do Crime tem raiz na Escola Clássica, onde a dicotomia prazersofrimento dá lugar à uma relação de custo $X$ benefício. Viapiana (2006) mostra que, assim como na Escola Clássica, a Economia do Crime pressupõe que a decisão do indivíduo em cometer o crime é racional e que ele a toma baseado na noção dos benefícios em contraposição aos custos diretos e indiretos.

Como este trabalho não tem como objetivo se estender sobre toda a diversidade de análise sobre o comportamento criminoso, foi elaborado o quadro 
abaixo que mostra resumidamente a relação entre as muitas teorias do crime, baseado no trabalho de Mendes (1997), com algumas adaptações.

Quadro 3 - Relação entre as diversas Teorias do Crime

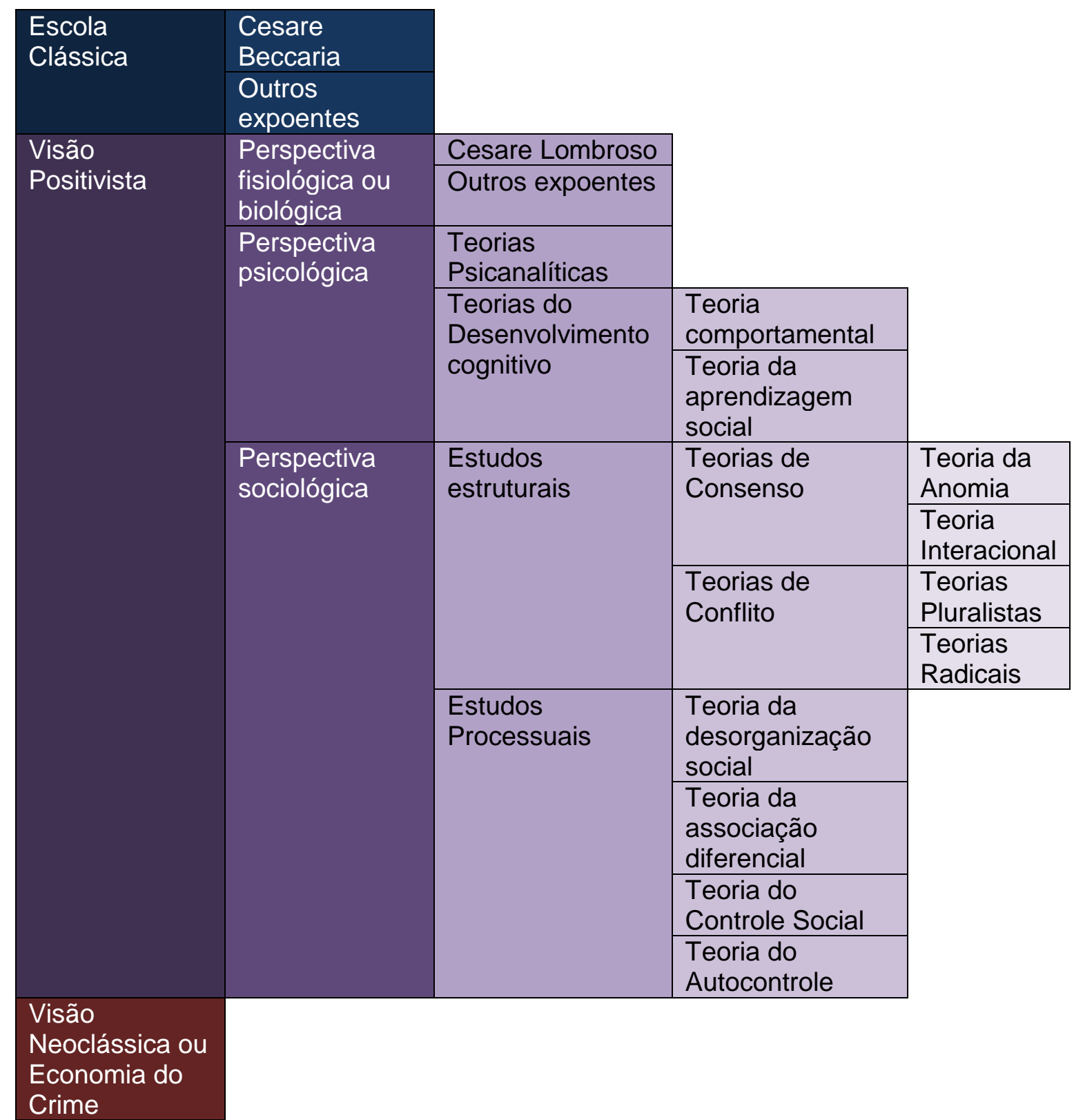

Fonte: Do autor

As Teorias da Criminalidade possuem olhares diferentes sobre as causas da escolha do crime. No entanto, para uma análise do crime à propriedade e consequentemente aos livros raros é mais pertinente o uso da Economia do Crime 
pois ela trabalha com o conceito de benefício financeiro, que, como visto, é bastante aplicável a uma obra rara. Ela também levanta a relação com os custos envolvidos, que permitem uma pesquisa direta nas instituições guardiãs deste tipo de acervo e o modo como se previnem com relação ao roubo ou furto; portanto, não é necessária uma análise minuciosa da sociedade na qual está inserido o criminoso, ou mesmo estudar as suas características individuais.

Quadro 4 - Comparativo entre as Escolas de estudo sobre o crime

\begin{tabular}{|c|c|c|c|}
\hline & Visão Clássica & Visão Positivista & Economia do Crime \\
\hline Decisão & Racional & Determinismo & Racional \\
\hline Motivação & $\begin{array}{l}\text { Elevação do prazer e } \\
\text { minimização } \\
\text { sofrimento }\end{array}$ & $\begin{array}{llr}\text { Pressão } & \text { social } & \text { e/ou } \\
\text { disfunção } & \text { biológica } & \text { ou } \\
\text { psicológica } & & \end{array}$ & $\begin{array}{l}\text { Análise da relação custo } \\
X \text { benefício sobre } 0 \\
\text { crime }\end{array}$ \\
\hline Dissuasão & Rigor penal & Reabilitação do indivíduo & $\begin{array}{l}\text { Rigor penal, Eficácia } \\
\text { Policial e Prevenção } \\
\text { situacional }\end{array}$ \\
\hline
\end{tabular}

Fonte: Do autor

\subsubsection{Economia do Crime}

A Economia do Crime é uma teoria que surgiu com os trabalhos de Becker (1968), que defendia a racionalidade do indivíduo na decisão de cometer um crime, ou seja, o criminoso leva em consideração uma relação entre custo e benefício, cometendo a infração se os benefícios sobressaírem com relação aos custos.

Do ponto de vista jurídico, a definição de crime está relacionada ao descumprimento da lei:

Considera-se crime a infração penal que a lei comina pena de reclusão ou de detenção, quer isoladamente, quer alternativa ou cumulativamente com a pena de multa; contravenção, a infração penal a que a lei comina, isoladamente, pena de prisão simples ou de multa, ou ambas, alternativa ou cumulativamente. (BRASIL, 1941, on-line)

No sentido econômico, Becker (1968) distingue o crime em duas categorias: lucrativos e não-lucrativos. Na primeira categoria estariam crimes como roubo, furto, 
estelionato, extorsão, entre outros e na segunda categoria os crimes como o estupro e o homicídio, por exemplo.

Para Viapiana (2006), a decisão de agir ilegalmente também envolve a percepção do indivíduo sobre os rendimentos que podem ser conseguidos nesta atividade, em contraposição aos que seriam conseguidos em uma atividade legal.

Em pesquisa feita por Shikida (2010) durante 10 anos ela verifica que as razões de naturez individual (cobiça e ambição; ganho fácil e manutenção de status) é fator relevante no ingresso do indivíduo no mundo do crime, pois os mesmos possuem esperança de que os ganhos esperados superem a renda oriunda das atividades lícitas. A autora ainda constata que o criminoso entrevistado, dificilmente conseguiria mudar suas condições de vida na atividade legal exercida por ele. Portanto, "esta constatação corrobora o fato de que os criminosos atribuem um valor monetário ao crime, e comparam este valor ao custo monetário envolvido na realização do mesmo" (SHIKIDA, 2010, p. 330).

O autor traz ainda uma equação que representa as relações entre custo e benefício, sendo Crime: b - p X c, onde "b" sãos os benefícios, "p" a probabilidade de prisão e "c" os custos diretos e morais. Portanto, a decisão individual de cometer o crime é incentivada quando ( $b-p X c)$ é maior que zero.

A noção do bandido sobre a probabilidade de prisão e os custos pode ser influenciada por uma série de variáveis:

A criminalidade estaria condicionada por uma vasta gama de fatores
(variáveis independentes) contribuintes para o entendimento do
comportamento criminal dos indivíduos (variável dependente). Entre as
variáveis independentes estão: faixa etária, gênero, escolaridade,
características do núcleo familiar e pertinência dos indivíduos a
determinados estratos sociais e econômicos "de risco". (SALVO, 2010, p. 5)

Para Schaefer e Shikida (2001), o objetivo da sociedade é tornar negativo o retorno lucrativo do criminoso e aumentar o risco da atividade criminosa, onde a sociedade busca aumentar os custos relacionados ao crime.

A Economia do Crime, para Kelly (2000), explica melhor os crimes contra a propriedade do que os crimes violentos, que seriam melhor entendidos pelas teorias 
de tensão e de desorganização social, pois os "crimes contra a propriedade envolvem ganhos materiais, que podem ser extensamente motivados pelo desejo de auto-enriquecimento dos ofensores, enquanto crimes contra a pessoa podem ser primariamente motivados por ódio ou paixão" (SANTOS; KASSOUF, 2008, p. 353).

A análise econômica do crime pode ser usada em todas as atividades ilegais lucrativas, pois Schaefer e Shikida (2001) mostram que os criminosos são como empresários, já que estes têm que assumir os riscos para a obtenção de lucro. No caso específico deste trabalho, a Economia do Crime ajuda a entender as variáveis presentes na tomada de decisão do criminoso, de modo a verificar como estão organizadas as estruturas que devem aumentar a percepção do bandido sobre a probabilidade de prisão e custos.

\subsubsection{Teoria da Dissuasão}

A proposição central da Teoria da Dissuasão, conforme Viapiana (2006), está ligada à estrutura de sanções, que podem ser de natureza legal ou extralegais. As de natureza legal se referem às taxas de prisão e condenação, que dependem da eficácia das ações policiais e judiciais; ou seja, o rigor penal imposto pela legislação e aplicado pelos juízes e os índices de prisão efetuados pela polícia aumentam a percepção do criminoso sobre a probabilidade de prisão e também sobre os custos da equação Crime $=b-p X c$.

Maia (2011) diz que os criminalistas passam a se preocupar mais com as informações diretas das situações que facilitaram a execução do crime, como espaço, luminosidade, acesso, vigilância, entre outras, em contraposição à análise dos fenômenos sociais que rondam o criminoso, dando ênfase na chamada prevenção situacional.

Para Rolim (2009), a prevenção situacional visa a dificultar o crime por meio do desenvolvimento de políticas e da criação de barreiras que tornem mais difícil a aproximação do bandido aos seus alvos, pois, segundo o autor, a maioria dos 
crimes contra o patrimônio são cometidos porque os infratores veem a situação como altamente favorável.

Para a elaboração de uma segurança focada na prevenção situacional é preciso ponderar que para a ocorrência do delito, é necessário um agressor motivado, um objeto disponível e ausência de vigilância, como mostra Carvalho (2004). De modo que os três fatores devem deixar de existir para que o criminoso mude o seu comportamento delitivo e não cometa o crime. A autora ainda mostra que para a Teoria das ações cotidianas o criminoso ao se sentir atraído por determinado objeto releva, o seu valor, seja econômico ou mesmo a sua importância para um grupo social, a inércia do objeto, ou seja, o seu tamanho e peso, a visibilidade do objeto, a exposição demasiada dele, como por exemplo, a ostentação de dinheiro na rua, e o acesso ao objeto, que corresponde a facilidade que 0 delinquente tem de alcançar o mesmo, muitas vezes caracterizada pela ausência de vigilância. "Para prevenir o delito, por meio da prevenção situacional, é importante romper com a cadeia que faz com que o delinqüente motivado encontre a vítima perfeita e o objeto desejado sem vigilância" (CARVALHO, 2004, p. 9).

Quanto a eficácia policial Shikida (2010) mostra que a maioria dos criminosos entrevistados considerou que as atividades policiais são ineficientes para coibir a atividade criminosa. No entanto, uma parcela dos entrevistados consideraram as ações policiais como o fator de malogro da atividade. Estas constatações mostram que existe um descrédito nas funções policiais, por parte dos criminosos, corroborado por pesquisas que mostram a baixa resolução da apuração dos crimes. Do mesmo modo, a polícia é fator imprescindível para que os criminosos sejam punidos e o aumento dos índices de resolução dos casos pode interferir diretamente nas taxas criminais.

O rigor de uma lei influencia diretamente nos custos envolvidos no crime, pois aumenta a percepção do bandido sobre os efeitos de uma condenação, caso seja descoberto. Viapiana (2006) mostra ainda que as mudanças na lei, tornando-a mais severa, contribuem para efeitos de condenação moral, pois muda o comportamento social, passando a sociedade a reprovar ainda mais uma conduta específica. 
A eficácia do sistema de justiça, na prevenção do crime econômico, pode contribuir na redução da incidência dos crimes. Para tanto, a ação deve ser justa e perfeita, aplicada de modo infalível e rapidamente, do contrário é provável que instigue a atividade criminosa através da sensação de impunidade, deixando de alcançar a função de intimidar ou desmotivar os criminosos. (SHIKIDA, 2010, p. 332)

A escola clássica na qual se baseou a Economia do Crime de Gary Becker diz que a pena tem que ser a retribuição da ação criminal, ou seja, na mesma proporção, como mostra Mendes (1997). Nesse sentido, o rigor penal demonstra a importância dada ao ato criminoso pela sociedade, onde o alto rigor seria para ações muito recriminadas socialmente e o baixo rigor para atos aceitáveis. Quanto à percepção do criminoso preso sobre o sistema judicial analisado por Shikida foi:

Ainda em relação ao sistema judiciário, a lentidão, a falta de informações
sobre os processos, a demora na revisão dos processos, a falta de
assistência social e jurídica e a inadequação das instalações (sistema
prisional) são fatores apontados para o descrédito do mesmo. Este
descrédito no sistema judiciário contribuiu para que metade dos
entrevistados tentasse fuga nas instituições prisionais em que cumpria
pena. (SHIKIDA, 2010, p. 333)

Neste trabalho, a Teoria da Dissuasão juntamente à Economia do Crime ajudam a traçar as variáveis que serão estudadas, pois demonstram aspectos relevantes a serem observados quanto à decisão do criminoso em cometer 0 ato ilegal e quanto às medidas que podem ajudar a frear a criminalidade.

\subsubsection{Economia do Crime, Teoria da Dissuasão e livros raros}

Os benefícios envolvidos no roubo ou furto de livros raros são condicionados pelo seu valor monetário e principalmente pelo valor histórico-cultural. No entanto, os custos do crime dependem principalmente do efeito de dissuasão (prevenção situacional, legislação, índices de prisão, índices de recuperação das obras e condenação dos criminosos).

Salvo (2010) mostra a dimensão da criminalidade envolvendo objetos culturais. Ele aponta que a Interpol não tem dados que possam demonstrar a extensão deste crime, ou seja, não é possível medir com exatidão a quantidade de obras roubadas e o valor que esse mercado ilegal movimenta, pois os países não remetem esses dados a eles e alguns sequer mantêm estatísticas sobre este tipo de 
crime. No entanto, ele mostra que o $\mathrm{FBI}$ alega que o mercado ilegal de bens culturais movimenta algo em torno de US\$ 6 bilhões anuais em todo o mundo, configurando a terceira atividade ilegal mais rentável.

Os valores que os livros raros atingem no mercado legal agem na percepção do criminoso sobre o benefício do crime sobre eles, fazendo com que os mesmos entrem para a lista de bens culturais roubados, o que pode ser observado nas notícias, mencionadas anteriormente, sobre roubos ou furtos de livros raros, levando à indagação de como estão os elementos que devem agir como dissuasores a estes atos criminosos.

A prevenção situacional propõe que, quanto mais elaborado o sistema de segurança, mais barreiras são criadas, dificultando o acesso do ladrão ao objeto de desejo e aumentando a probabilidade de sua prisão. Rolim (2009, p. 52) mostra que o aumento da dificuldade de aproximação do alvo, o estímulo das políticas públicas para as pessoas agirem corretamente e a melhoria nas condições de vigilância (polícia, câmeras, iluminação, entre outros) aumentam a percepção dos riscos e custos de uma ação criminosa.

O criminoso terá que despender mais tempo na elaboração e preparação do crime e, em alguns casos, haverá mais gasto monetário na criação de uma situação mais favorável à invasão, principalmente em crimes contra a propriedade. Portanto, as condições situacionais das instituições guardiãs de livros podem influenciar positiva ou negativamente na decisão dos ladrões. No contexto apresentado por Carvalho (2004) em que a atração do criminoso por um objeto se dá pelo seu valor, inércia, visibilidade e acesso, a prevenção situacional surge para inibir principalmente o acesso aumentado a vigilância sobre o alvo. Portanto, no caso do livro raro o foco deve estar na prevenção situacional, pois, o seu valor é atrativo, seu tamanho permite raptá-lo e escondê-lo com facilidade e a sua exposição é muitas vezes feita em catálogos online, com seus dados disponíveis publicamente com casos de digitalização completa da obra.

No que tange à legislação brasileira sobre a preservação de livros raros é possível ver que os mesmos são tratados nas leis que tratam de Patrimônio Cultural 
como um todo. A lei que trata especificamente sobre livros é a Lei 5.471/68, que dispõe sobre a exportação de livros antigos e conjuntos bibliográficos brasileiros.

De acordo com Ponte (2006), o legislador brasileiro age em relação ao crime contra o Patrimônio Cultural de acordo com o princípio da intervenção mínima, ou seja, só se justifica a atuação diante do Direito Penal quando os demais ramos do Direito se mostrarem bastante inócuos.

A título exemplificativo, quem destrói, inutiliza ou deteriora arquivo, registro,
museu, biblioteca, pinacoteca, instalação científica ou similar protegido por
lei, ato administrativo ou decisão judicial, estará sujeito a uma pena privativa
de liberdade de um a três anos de reclusão, além do pagamento de multa.
Se o autor de tal infração for primário e lhe forem favoráveis as condições
mencionadas pelo artigo 59 do Código Penal, o Promotor de Justiça poderá
oferecer a proposta de suspensão condicional do processo, que se aceita,
fará com que o feito fique suspenso por um determinado período e o
acusado submetido a uma série de condições. Ultrapassado tal lapso
temporal sem qualquer incidente, será julgada extinta a punibilidade do
agente. (PONTE, 2006, p. 9)

O contexto que envolve o roubou ou furto de livros raros dá indícios que os elementos punitivos determinados pela Teoria da Dissuasão que interferem diretamente nos custos do crime, previstos pela Economia do Crime, não estão funcionando como agentes inibidores desta ação ilegal. No entanto, há benefícios consideráveis que aumentam a percepção do bandido sobre os seus ganhos.

\subsection{Referencial teórico}

Os conceitos abordados durante a revisão de literatura aqui serão delimitados para expressar o que a pesquisa considera como relevante, pois os conceitos têm múltiplas abordagens, sendo necessário demonstrar qual se adequa melhor ao trabalho. Os conceitos fundamentais para o entendimento da pesquisa são: obras raras, livro raro, roubo, furto, Economia do Crime, Teoria da Dissuasão e prevenção situacional.

Apesar de não existir uma definição clara de obra rara, para este trabalho são consideradas aquelas obras que têm características como a da definição: "livro assim designado por ser detentor de alguma particularidade especial (antiguidade, autor célebre, conteúdo polêmico, papel, ilustrações)" (FARIA; PERICÃO, 2008, p. 
469), ou seja, tem que haver alguma particularidade especial que diferencie o livro raro do livro comum. Alguns autores qualificam outros materiais, além do livro, como sendo obra rara. No caso de Silva (2011) o conceito de obra rara engloba não só o livro, mas também teses, manuscritos iluminados e caligrafados, histórias em quadrinhos, mapas, selos e moedas. Sant'ana (2001) considera obra rara os livros, os periódicos, os mapas, as folhas volantes, os cartões postais, entre outros materiais. Reifschneider (2008) defende a acomodação de fotografias originais, cartões postais, desenhos e pinturas de escritores e artistas relevantes, nas coleções de obras raras caso na instituição não haja um setor específico para acomodar estes materiais.

Alguns autores, no entanto, consideram obra rara como sendo apenas o livro impresso raro, como é o caso de Froes (1995), Faria e Pericão (2008), Santos e Albuquerque (2010) e Cunha e Cavalcanti (2008). Gauz (1994) usa o termo acervo raro, que em sua definição engloba apenas o livro impresso raro. Assim como, Pinheiro (1989, 2007, 2009a, 2009b) prefere usar em seus trabalhos apenas o termo livro raro. Diante da divergência de definições do termo obra rara, é possível identificar que o livro impresso raro está contemplado em todas elas. Portanto, o presente trabalho irá usar preferencialmente o termo livro raro, e em alguns casos, o termo obra rara como sinônimo de livro impresso raro, apenas. Sendo assim, os casos de roubo e furto analisados, contemplaram apenas aqueles onde há o envolvimento de ao menos um livro impresso raro.

Como a pesquisa está centrada no roubo e furto de livros raros, torna-se importante conceituar essas duas modalidades. Os usos para roubo e furto, na pesquisa, vêm da significação jurídica dada a esses termos, ou seja, a diferença principal entre roubo e furto está no emprego de violência no primeiro caso, como mostra a definição de roubo:

Subtração clandestina de coisa alheia móvel, para si ou para outrem, mediante grave ameaça ou violência a (sic) pessoa, ou reduzindo-a (sic) à impotência para reagir. Distingue-se do furto, porque neste não ocorre a violência, prevalecendo a astúcia e a habilidade (ACQUAVIVA, 2013, p. 800) 
O aporte teórico da Economia do Crime para a pesquisa é centrado na racionalidade do criminoso e no ganho monetário vindo da infração, que leva em conta a relação de custo $\mathrm{X}$ benefício do crime, como apresentando por Becker (1968), descrita por Viapiana (2006) na fórmula Crime $=b-p$ X c, onde, "b" corresponde aos benefícios, "p" à probabilidade de prisão e "c" aos custos diretos e morais.

A Teoria da Dissuasão ajuda a limitar as variáveis estudadas com relação ao crime de livros raros, pois enfoca a percepção do bandido sobre os custos envolvidos na ação criminosa por meio das medidas de punição. Viapiana (2006) mostra que o efeito de dissuasão está ligado à ação eficaz e eficiente da polícia e da justiça.

A certeza da punição traz a diminuição dos casos de crimes, como mostra a Teoria da Dissuasão. Neste contexto, a prevenção situacional age como uma aliada na percepção dos custos envolvidos na atividade criminosa.

A prevenção situacional é uma área em que a polícia tem atuação
privilegiada; refere-se a prever influências situacionais, sendo direcionada
para tipos específicos de infrações e para reduzir a possibilidade de um
jovem infringir as leis. São ações como colocação de câmaras para
aumentar a vigilância em locais com alta incidência de crimes (ASSIS;
CONSTANTINO, 2005, p. 88).

A prevenção situacional também aumenta a percepção sobre a certeza de punição, pois o uso de câmeras, alarmes e instrumentos de contenção podem fazer com que o criminoso seja surpreendido cometendo o ato infracional ou identificado $e$ preso posteriormente. 
Figura 28 - Modelo conceitual

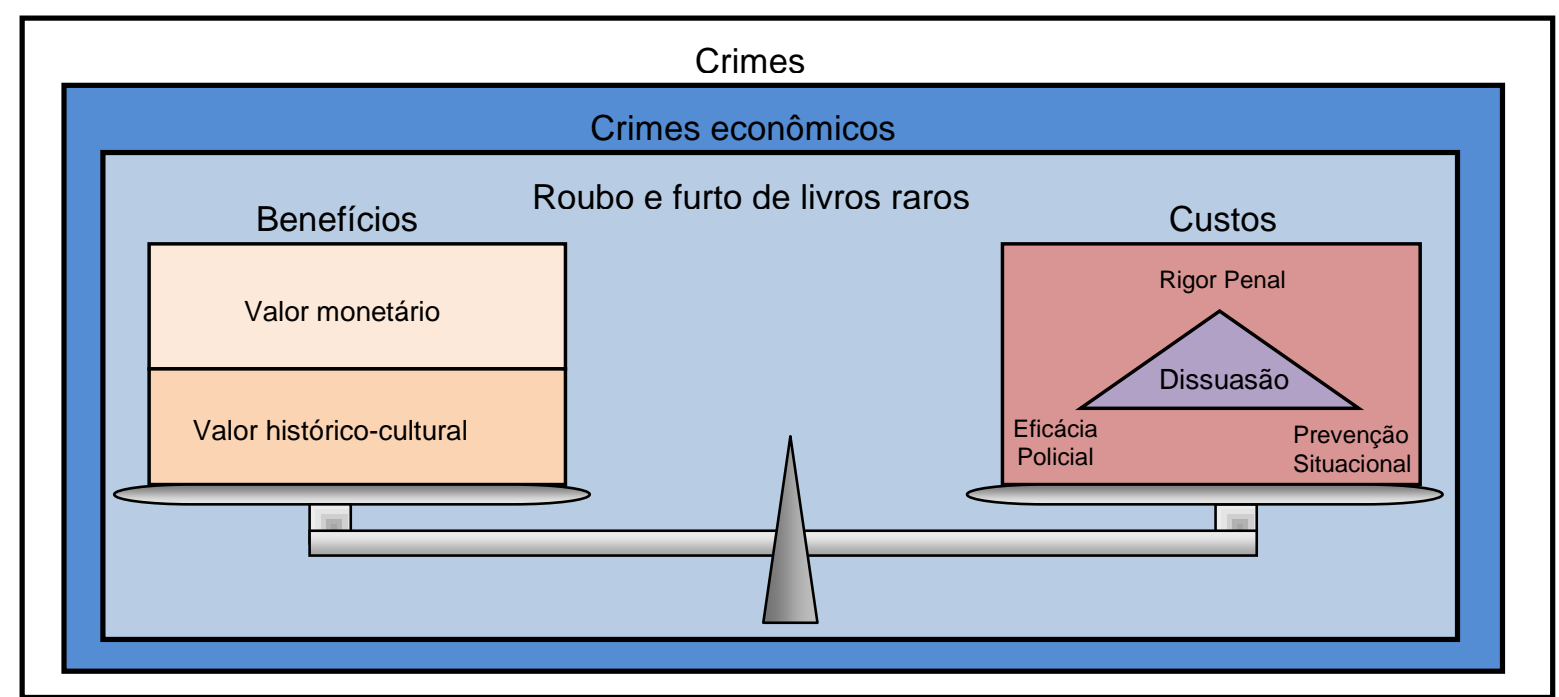

Fonte: Do autor

O modelo conceitual descreve de forma simplificada a relação entre os conceitos descritos no referencial teórico. Portanto, no âmbito geral da criminalidade existem crimes que trazem retorno financeiro ao criminoso. $O$ roubo e o furto de livros raros se enquadram neste tipo de crime, pois sempre existe um valor históricocultural associado a este objeto que influencia diretamente no valor econômico que ele possa atingir. Estes crimes acontecem, segundo a Economia do Crime, após a decisão racional dos criminosos, que ponderam uma relação de custo $X$ benefício. Associados aos benefícios estão os valores econômico e histórico-cultural da obra, enquanto os custos, segundo a Teoria da Dissuasão, são elevados pela certeza de punição. A certeza de punição está condicionada à eficiência e eficácia da polícia e da justiça, além da prevenção situacional que aumenta as chances de prisão dos criminosos. 


\section{Metodologia}

A pesquisa tem característica quali-quantitativa por envolver fenômenos quantificáveis analisados por meio de técnicas estatísticas, mas também de variáveis que não são passíveis de análise por meio de dados numéricos. Também é uma pesquisa tanto exploratória quanto descritiva, pois apesar de fazer uma pesquisa com uma população estabelecida com coleta de dados controlada, também foi necessária a pesquisa documental para identificar variáveis que não estão contempladas no primeiro caso.

A Teoria da Dissuasão mostra que o efeito da punição aumenta a percepção do criminoso para os custos da ação criminal. Portanto, além da eficácia policial e judicial na detenção e condenação dos criminosos (sanções legais) é analisada a prevenção situacional, ou seja, são analisadas as condições de segurança das instituições guardiãs de livros raros, pois a dificuldade imposta por essas instituições aumenta a percepção do bandido sobre os custos da operação criminosa e aumenta também a probabilidade de prisão, influenciando diretamente nas eficácias policial e judicial.

Foram realizadas três etapas para coleta dos dados para atingir os objetivos geral e específicos. A primeira etapa consistiu na aplicação de questionário nas instituições que possuem livros raros, cadastradas no Plano Nacional de Recuperação de obras raras (Planor), a segunda no levantamento dos crimes ocorridos com aplicação de questionários nas instituições e consulta às Polícias Federal e Civil, além de consulta aos processos judiciais referentes a cada caso. $\mathrm{Na}$ terceira etapa foram entrevistados os especialistas, um delegado da Polícia Federal e membros do Instituto do Patrimônio Histórico e Artístico Nacional (Iphan). Portanto, foram levantados dados sobre a eficácia policial, o rigor penal e a prevenção situacional.

A averiguação da eficácia policial foi feita por meio do levantamento dos casos de prisão e recuperação das obras. Este levantamento foi feito junto às Polícias Federal e Civil dos estados brasileiros onde ocorreram os crimes, às instituições roubadas ou furtadas e nos processos criminais ligados a essas 
instituições. Também foi realizada entrevista com delegado da Polícia Federal para levantamento das ações policiais no combate ao roubo e furto de livros raros e das ações de prevenção situacional nas instituições.

O rigor penal foi verificado por meio da comparação das penas dadas aos criminosos indiciados e a pena máxima prevista pelo código penal para os crimes de furto qualificado. Também foi analisada a legislação brasileira de proteção ao patrimônio cultural e em específico aquela ligada diretamente aos livros raros.

As condições da prevenção situacional nas instituições guardiãs de livros raros foram levantadas por meio da aplicação de questionário semiestruturado, enviado por e-mail, após contato telefônico, a todas as instituições cadastradas no Planor, pois apesar da listagem destas instituições ser elaborada por iniciativa delas próprias, ainda é preferível segui-la a fazer uma pesquisa aleatória de quais instituições possuem livros raros. Foram realizadas entrevistas com especialistas na gestão deste tipo de acervo, para averiguação das condições ideais de segurança que uma instituição deve adotar. Foi também realizada entrevista com representantes do Iphan, para entender a participação da instituição na prevenção contra roubo e furto, com a aplicação do tombamento e a criação da legislação de preservação do patrimônio cultural. Assim como foi analisada a adoção de medidas de emergência, como a inclusão dos itens no Banco de Dados de Consulta a Bens Culturais Procurados. ${ }^{31}$

\subsection{Desenho da pesquisa}

A coleta de dados por meio da pesquisa bibliográfica, da aplicação de questionário junto às instituições guardiãs de livros raros, da pesquisa documental nos processos judiciais e as entrevistas com delegado da Polícia Federal, especialistas em gestão de livros raros e membros do Iphan foram realizadas para atender todos os objetivos específicos da pesquisa.

\footnotetext{
${ }^{31}$ Site do Banco de Dados de Consulta a Bens Culturais Procurados: http://portal.iphan.gov.br /consultaPublicaBCP/index.jsf
} 
Quadro 5 - Desenho da pesquisa

\begin{tabular}{|c|c|c|}
\hline Objetivos específicos & $\begin{array}{c}\text { Métodos de } \\
\text { investigação }\end{array}$ & dados \\
\hline $\begin{array}{lrr}\text { Identificar e } & \text { analisar } & \text { os } \\
\text { processos e a estrutura de } & \\
\text { segurança } & \text { adotados } & \text { nas } \\
\text { instituições } & \text { guardiãs } & \text { de } \\
\text { livros raros; } & & \\
\end{array}$ & $\begin{array}{l}\text { - Questionário } \\
\text { - Entrevistas }\end{array}$ & $\begin{array}{llr}\text { - } & \text { Amostra da pesquisa } \\
\text { (Instituições cadastradas no } \\
\text { Planor) } \\
\text { - } & \text { Entrevistas } \\
& \text { especialistas } & \\
\end{array}$ \\
\hline $\begin{array}{l}\text { listar e analisar os casos de } \\
\text { roubos ou furtos de livros } \\
\text { raros no Brasil; }\end{array}$ & $\begin{array}{ll}\text { - } & \text { Pesquisa } \\
\text { bibliográfica } \\
\text { documental } \\
\text { - } & \text { Entrevista }\end{array}$ & $\begin{array}{l}\text { - } \text { Notícias de roubo e furto } \\
\text { - Questionário com } \\
\text { instituições roubadas ou } \\
\text { furtadas } \\
\text { - Entrevista com delegado da } \\
\text { PF } \\
\text { - Processos Judiciais }\end{array}$ \\
\hline $\begin{array}{l}\text { identificar e analisar o índice } \\
\text { de recuperação dos livros } \\
\text { raros roubados ou furtados. }\end{array}$ & $\begin{array}{ll}\text { - } & \text { Pesquisa } \\
\text { bibliográfica } \\
\text { documental } \\
\text { - } & \text { Entrevista }\end{array}$ & $\begin{array}{l}\text { - Notícias de recuperação de } \\
\text { livros raros } \\
\text { - Questionário } \\
\text { instituições roubadas ou } \\
\text { furtadas } \\
\text { - Entrevista com delegado da } \\
\text { PF } \\
\text { - Processos Judiciais }\end{array}$ \\
\hline $\begin{array}{l}\text { analisar a legislação } \\
\text { pertinente ao contexto de } \\
\text { livros raros e a consequente } \\
\text { aplicação da lei no caso de } \\
\text { roubos e furtos dessas } \\
\text { obras; }\end{array}$ & $\begin{array}{ll}\text { - } & \text { Pesquisa } \\
\text { bibliográfica } \\
\text { documental } \\
\text { - Entrevista }\end{array}$ & $\begin{array}{llr}\text { - } & \text { Legislação } & \text { brasileira } \\
\text { (Constituição } & \text { Federal, } \\
\text { Código Civil e Código } \\
\text { Penal) } \\
\text { - } \text { Casos de julgamento de } \\
\text { ladrões de livros raros } \\
\end{array}$ \\
\hline $\begin{array}{l}\text { estabelecer relação entre a } \\
\text { Economia do Crime e o } \\
\text { roubo e furto de livros raros; }\end{array}$ & $\begin{array}{ll}\text { - } & \text { Pesquisa } \\
& \text { bibliográfica }\end{array}$ & - Revisão de literatura \\
\hline $\begin{array}{l}\text { identificar o índice de prisão } \\
\text { e condenação dos autores } \\
\text { de roubos ou furtos de livros } \\
\text { raros. }\end{array}$ & $\begin{array}{ll}\text { - } & \text { Pesquisa } \\
\text { bibliográfica } \\
\text { documental } \\
\text { - } & \text { Entrevista } \\
\end{array}$ & $\begin{array}{ll}\text { - } & \text { Notícias sobre prisões } \\
\text { - } & \text { Entrevista com delegado da } \\
& \text { PF } \\
\text { - } & \text { Processos judiciais }\end{array}$ \\
\hline
\end{tabular}

\subsection{Universo e amostra}

A pesquisa fez um levantamento da eficácia policial, por meio do índice de prisão e do índice de recuperação das obras, do rigor penal e da qualidade da prevenção situacional, para analisar o efeito de dissuasão nos crimes de roubo e furto de obras raras. 
A avaliação da eficácia policial foi feita principalmente com o estabelecimento da recuperação de obras dos crimes conhecidos, já que notou-se ser inviável estabelecer o índice de prisão. O estabelecimento do rigor penal na pesquisa também tem relação direta com os crimes conhecidos, pois foram analisados os casos de condenação relacionados a estes crimes. Portanto, as notícias de roubos e furtos que fazem parte da pesquisa, levantadas a partir de pesquisa documental, correspondem a uma amostra não probabilística por acessibilidade, como chama Gil (2008). Richardson (2011) mostra que este tipo de amostra corresponde ao subconjunto da população pelos elementos que se pôde obter, com a desvantagem de não se poder generalizar os resultados, já que não há qualquer certeza da representatividade da amostra em relação ao universo.

Os crimes de roubo e furto analisados são aqueles em que há pelo menos um livro raro envolvido; ou seja, os crimes como o da Casa de Rui Barbosa em 2001, e da Biblioteca Nacional, em 2010, não são analisados, pois as obras se enquadram na categoria de periódicos, não havendo notícias da presença de livros raros na listagem de obras furtadas. Em contato com a Polícia Federal foi mencionada a recuperação de obras, em 2005, da Biblioteca da Delegacia Regional do Trabalho e Biblioteca do Tribunal Marítimo do Ministério da Marinha/RJ. Em contato com a Biblioteca do Tribunal Marítimo, a instituição disse que esta obra não tem as características do seu acervo e que no período em que a obra foi recuperada a biblioteca encontrava-se fechada e por esse motivo a obra deve ter sido encaminhada a outra instituição. Não foi possível manter contato com a Biblioteca da Delegacia Regional do Trabalho e por isso, o caso das duas instituições foi retirado da amostra pesquisada. Os casos que foram analisados são:

1 Instituto de Pesquisas Jardim Botânico (Rio de Janeiro)

2 Palácio do Itamaraty (Rio de Janeiro)

3 Museu Histórico Nacional (Rio de Janeiro)

4 Museu Nacional da Universidade Federal do Rio de Janeiro

5 Escola de Belas Artes da Universidade Federal do Rio de Janeiro 
6 Arquivo Geral da Cidade do Rio de Janeiro

7 Biblioteca Mário de Andrade (São Paulo)

8 Biblioteca Pública do Paraná

9 Museu Chácara do Céu (Rio de Janeiro)

10 Fundação Oswaldo Cruz (Rio de Janeiro)

11 Instituto Geográfico e Histórico da Bahia

12 Museu Paraense Emílio Goeldi

13 Instituto de Botânica (São Paulo)

14 Centro de Ciências, Letras e Artes de Campinas (São Paulo) ${ }^{32}$

Os processos judiciais analisados, ou partes destes foram:

\section{Justiça Federal do Rio de Janeiro:}

- $1^{\mathrm{a}}$ Vara Federal Criminal:

Processo criminal no 0523293-31.2004.4.02.5101.

- 2 $2^{\mathrm{a}}$ Vara Federal Criminal:

Sentença do processo criminal $n=0517641-33.2004 .4 .02 .5101$.

- 4 $4^{\mathrm{a}}$ Vara Federal Criminal:

Processo criminal ํㅜ 0800583-02.2008.4.02.5101.

- 6a Vara Federal Criminal:

Processo criminal no 0513911-48.2003.4.02.5101.

Sentença do processo criminal no 0807693-18.2009.4.02.5101.

- $10^{\underline{a}}$ Vara Federal Criminal:

\footnotetext{
${ }^{32}$ Nessa instituição foram analisados dois casos, um de furto, em 2004, e outro de roubo, em 2013.
} 
Processo criminal no 0514146-78.2004.4.02.5101.

Processo criminal no 0509504-91.2006.4.02.5101.

- Tribunal Regional Federal da 2 ${ }^{\mathrm{a}}$ Região:

Acórdão da apelação criminal ํo ACR/6763.

Acórdão da apelação criminal nº ACR/8022.

Acórdão da apelação criminal nº ACR/8341.

Acórdão dos embargos infringentes ํㅡㄹ ENUL/6612.

Decisão sobre pedido de recursos especiais na apelação criminal ํำ ACR/8022.

Decisão sobre pedido de recursos especiais na apelação criminal nº ACR/8341.

\section{Superior Tribunal de Justiça:}

Decisão do recurso especial no 1256898/RJ.

\section{Tribunal de Justiça do Estado de São Paulo:}

- $7^{\mathrm{a}}$ Câmara de Direito Criminal:

Decisão sobre a apelação criminal no 993.06.065158-7.

- $30^{\mathrm{a}}$ Vara Criminal da Capital:

Sentença do processo criminal no $050.04 .038423-3$.

\section{Tribunal de Justiça do Paraná:}

- 11 Vara Criminal do Foro Central de Curitiba:

Processo Criminal ํㅜㄹ 2007.0003086-7.

A relação das instituições que possuem coleções de livros raros foi obtida a partir do Plano Nacional de Recuperação de obras raras (Planor), uma ação da Biblioteca Nacional para prestar assistência às instituições curadoras de livros raros ajudando a disseminar informações sobre obras raras a quem interesse. 
A relação de instituições cadastradas no Planor está disponível no seu portal e corresponde, portanto, ao universo da pesquisa. Apesar de não corresponder ao total exato de instituições que possuem coleções de obras raras em todo o Brasil, ainda é preferível o uso deste cadastro em vez da identificação aleatória destas instituições.

O total de instituições cadastradas no Planor é 150 (ANEXO A) ${ }^{33}$. No entanto, quatro instituições não possuem qualquer dado para contato. O Planor disse não ter essas informações por preservar a privacidade das instituições que podem não fornecer os dados necessários. Portanto, as instituições foram retiradas do universo da pesquisa.

A Fundação Clemente Mariani, presente na listagem retirada do Planor, disse que o seu acervo foi doado para a Universidade Federal do Recôncavo da Bahia, que não está na listagem, com isso a primeira instituição foi eliminada da amostra e a segunda inserida. A Faculdade Católica de Administração e Economia (FAE) de Curitiba informou que o seu acervo foi transferido para a Universidade São Francisco em Bragança Paulista, a primeira instituição foi retirada da amostra e a segunda já fazia parte do cadastro do Planor. O Museu de Arte Sacra da Universidade Federal da Bahia, cadastrado no Planor, informou que seu acervo raro foi transferido para a Biblioteca Central da mesma universidade, que não estava na listagem do Planor, portanto a primeira instituição foi retirada da amostra e a segunda inserida. Das instituições cadastradas no Planor, nove delas, no primeiro contato telefônico, disseram não possuir uma coleção de obras raras e por isso foram excluídas da amostra. Com apenas uma instituição, não foi possível estabelecer qualquer contato para envio do questionário e por isso a mesma foi excluída da amostra. A inclusão dessas instituições na amostra representa que o questionário foi enviado a elas, mas não significa que estas fazem parte do grupo de respondentes.

Ao todo foram pesquisadas 135 instituições. Optou-se por enviar questionário a todas as instituições devido ao número reduzido de indivíduos que compõem o

\footnotetext{
${ }^{33}$ Lista de instituições retirada do site oficial do PLANOR em 08 fev. 2012.
} 
universo da pesquisa e por ser prevista a não adesão de todas as instituições como respondentes, devido ao tema delicado da pesquisa.

As entrevistas com especialistas e delegado da Polícia Federal, correspondem a uma amostra intencional, pois foram escolhidos aqueles considerados os maiores especialistas no assunto, pertencentes a grandes instituições, assim como o delegado corresponde ao estado em que mais se tem conhecimento de casos de roubo ou furto de livros raros. Do mesmo modo, foi realizada entrevista com representantes do Iphan sediados em Brasília. Os entrevistados são:

Entrevistado A: Chefe da Seção de obras raras da Biblioteca Nacional, no Rio de Janeiro.

Entrevistado B: Diretora Geral do Arquivo Geral da Cidade do Rio de Janeiro.

Entrevistado C: Funcionário da Biblioteca Nacional que já chefiou a Seção de Promoções Culturais, a Divisão de Fotografia e a Divisão de Iconografia.

Entrevistado D: Delegado responsável pela Delegacia do Meio Ambiente e Patrimônio Histórico (Delemaph) da Polícia Federal do Rio de Janeiro.

Entrevistado E: Coordenador-Geral de Patrimônio Natural (CGPN) do Iphan

Entrevistado F: Técnica em História da Arte do Iphan. Em entrevista conjunta com o Entrevistado $\mathrm{E}$.

\subsection{Instrumentos de coleta de dados}

A coleta de dados foi realizada usando três métodos distintos. $\mathrm{Na}$ identificação dos crimes de roubo e furto de livros raros foi feita uma pesquisa documental. Portanto, foram usadas fontes oficiais, científicas e casuais para obtenção dos dados, sendo investigados os meios de comunicação de massa, principalmente os disponíveis online, também a literatura científica relacionada ao tema, os relatórios originados pelas investigações policiais e os processos judiciais. 
A obtenção dos dados a partir dos documentos foi feita a partir da análise de conteúdo, como mostra Gil (2008), seguindo as etapas de pré-análise, exploração do material e tratamento dos dados, inferência e interpretação. A análise de conteúdo teve como objetivo retirar detalhes das notícias sobre roubo ou furto de obras, tais como onde, quando e de que forma ocorreram. Outras informações consideradas relevantes foram a quantidade e quais obras foram levadas, e também a indicação de suspeitos. A análise junto às Polícias Federal e Civil e junto aos tribunais trouxe dados referentes ao indiciamento de suspeitos e possível condenação dos mesmos.

A segunda etapa da coleta de dados foi realizada junto ao universo das instituições guardiãs de livros raros. Foi aplicado questionário semiestruturado, enviado online por formulário do Google Drive, e foram feitos também contatos telefônicos, para apresentação da pesquisa e cobrança de preenchimento do questionário, na tentativa de garantir o maior número de respondentes.

O questionário aplicado tem suas perguntas estruturadas na seguinte ordem: dados sobre a instituição; dados sobre o setor de obras raras; dados sobre a segurança física do setor de obras raras; dados sobre a segurança eletrônica; dados sobre a equipe de segurança e guarda das chaves; dados sobre o controle do acervo e dados sobre o responsável pela coleção.

A terceira etapa visou a entrevistar especialistas na gestão de livros raros, delegado da Polícia Federal e integrantes do Iphan. As entrevistas foram guiadas por questionário semiestruturado (ANEXOS E, F e G), com a seleção de temas que levaram às perguntas, sem restringir a iniciativa do entrevistado, como sugere Richardson (2011).

\subsubsection{Pré-teste}

No intuito de testar o instrumento de coleta de dados como propõe Richardson (2011), foi aplicado um pré-teste com três membros da população das instituições guardiãs de livros raros. No entanto, apenas dois responderam. Como 
essa etapa foi realizada com todo o universo da pesquisa, as respostas dos membros entraram na análise de dados.

O pré-teste ajudou a modificar uma questão duplicada que induzia 0 respondente ao erro, ao falar de condições de segurança na janela, em duas perguntas, sendo que uma se referia mesmo a janela, mas a outra deveria ser sobre as portas. Foi acrescentada também a pergunta final, que possibilita que 0 respondente coloque dados livres que não tenham sido contemplados nas perguntas anteriores. Essa atitude foi tomada em decorrência da orientação de uma respondente do pré-teste que considerou as perguntas, de um modo geral, inflexíveis, não contemplando a variedade de situações que podem ocorrer nas diversas instituições pesquisadas. 


\section{Análise dos dados}

A análise de dados foi realizada em três etapas. Na primeira foram analisados os dados relacionados à prevenção situacional, respondidos pelas instituições que possuem livros raros, cadastradas no Planor. Na segunda etapa foram analisados os dados relacionados aos roubos e furtos de livros raros, aos crimes levantados na mídia, na literatura e nos documentos dos processos judiciais, assim como foram analisados os casos de desaparecimento de livros raros, informados pelas instituições na questão 75 do questionário sobre prevenção situacional. Nesta segunda etapa, portanto, foram verificadas a eficácia policial e o rigor penal aplicados nesses crimes. Conforme estabelecido junto às instituições, os nomes das respondentes não foram revelados para que pudesse ser mantida a integridade de seus sistemas de segurança. A terceira etapa consistiu na análise das entrevistas com especialistas, delegado da Polícia Federal e membros do Iphan.

\subsection{Primeira etapa - Prevenção Situacional}

Os dados foram divididos em 7 Blocos, conforme a estrutura do questionário aplicado. Os Blocos são: dados sobre a instituição; dados sobre o setor de obras raras; dados sobre segurança física do setor de obras raras; dados sobre segurança eletrônica no setor de obras raras; dados sobre a equipe de segurança e guarda de chaves; dados sobre o controle do acervo; dados sobre o responsável pela coleção de obras raras. Das 135 instituições que correspondem ao universo da pesquisa, 82 $(60,74 \%)$ responderam ao questionário.

\subsubsection{Dados sobre as instituições}

A maioria das instituições funciona em dois turnos ou mais; $46(56,1 \%)$ funcionam manhã e tarde, enquanto $32(39,02 \%)$ manhã, tarde e noite. Uma instituição $(1,22 \%)$ funciona apenas pela manhã e $3(3.66 \%)$ apenas durante a tarde. 
Uma grande quantidade de instituições possui nenhum ou apenas um bibliotecário, totalizando 25 de todas as respondentes (30,5\%). O(a) bibliotecário(a) é o(a) profissional indicado(a) para a gestão de coleções de livros raros; portanto, a ausência ou baixa quantidade desse(a) profissional pode implicar na qualidade da segurança aplicada a esse acervo.

Tabela 1 - Quantidade de funcionários nas instituições respondentes

\begin{tabular}{lcccc}
\hline & Bibliotecários & Estagiários & Terceirizados & Voluntários \\
\hline Nenhum & 6 & 16 & 26 & 42 \\
$\mathbf{1 - 5}$ & 43 & 34 & 23 & 8 \\
$\mathbf{6 - 1 0}$ & 11 & 10 & 4 & 0 \\
$\mathbf{1 1 - 1 5}$ & 5 & 3 & 3 & 0 \\
$\mathbf{1 6 - 2 0}$ & 3 & 1 & 2 & 0 \\
$\mathbf{2 1 - 2 5}$ & 2 & 1 & 2 & 0 \\
$\mathbf{2 6 - 3 0}$ & 5 & 0 & 0 & 0 \\
Acima de $\mathbf{3 0}$ & 4 & 4 & 4 & 0 \\
Omissos & 3 & 13 & 18 & 32 \\
\hline \multicolumn{5}{r}{} \\
\hline
\end{tabular}

A grande quantidade de casos omissos nesta questão pode ser explicada pelo fato dos respondentes não indicarem qualquer valor quando sua resposta seria zero. No entanto, os casos omissos nesta pesquisa não serão considerados como zero para não incorrer em erros.

Os respondentes foram perguntados sobre categorias diferentes das acima citadas, na categoria "outros". Foram incluídos como funcionários das instituições os auxiliares de biblioteca, auxiliares e técnicos administrativos, técnicos em documentação, bolsistas, seguranças, recepcionistas, secretárias, auxiliares de serviços gerais, professores, arquivistas, historiadores, geógrafos, conservadores e restauradores.

A questão 4 perguntou sobre os diversos ambientes que existem na instituição, pois os diferentes espaços dentro da mesma instituição exigem níveis de segurança diversos, já que podem servir de áreas de esconderijo ou de escape do criminoso, como é o caso das instituições que disponibilizam banheiros para os usuários, por exemplo, que são locais onde não é ético o uso de câmeras para 
monitoração, mas que são espaços que devem estar contemplados em um plano de segurança. As respostas podem variar, pois foram dadas muitas opções para marcação no questionário. Os banheiros para usuários só não foram citados em 4 respostas, além dos 7 casos omissos e das 2 respostas que consideram a instituição como único ambiente. As respostas que deram as mesmas opções foram:

Tabela 2 - Espaços de circulação de usuários

\begin{tabular}{lc}
\hline \multicolumn{1}{c}{ Opções } & $\begin{array}{c}\text { Quantidade de } \\
\text { respostas }\end{array}$ \\
\hline Banheiro para usuários & 11 \\
$\begin{array}{l}\text { Banheiro para usuários, Estacionamento } \\
\text { Banheiro para usuários, Estacionamento, } \\
\text { Reprografia }\end{array}$ & 4 \\
$\begin{array}{l}\text { Banheiro para usuários, Estacionamento, } \\
\text { Reprografia, Laboratório de informática } \\
\text { Banheiro para usuários, Reprografia }\end{array}$ & 6 \\
$\begin{array}{l}\text { Banheiro para usuários, Reprografia, } \\
\text { Laboratório de informática }\end{array}$ & 4 \\
$\begin{array}{l}\text { Livraria, Lanchonete, } \\
\text { Banheiro para usuários, Estacionamento, } \\
\text { Reprografia, Laboratório de informática }\end{array}$ & 5 \\
\hline
\end{tabular}

Fonte: Do autor

Estas 7 categorias de respostas representam $46,34 \%$ dos respondentes, ou $50,66 \%$, desconsiderando-se os casos omissos. Das instituições respondentes, 37 $(45,12 \%)$ escolheram de duas a quatro opções, entre as 7 opções disponíveis e 10 instituições (12,2\%) assinalaram 5 ou mais opções. Ainda 13 instituições (15,85\%) além de escolher uma das 7 opções dadas, ainda apontaram outros locais que fazem parte delas e que são diferentes daqueles que a maioria possui. Entre as áreas apontadas estão o espaço infantil, auditórios, sala de microfilmagem, salas de treinamento, pousada, restaurante, entre outros. 
Tabela 3 - Quantidade de opções assinaladas na questão sobre espaços de circulação de usuários

\begin{tabular}{lc}
\hline $\begin{array}{c}\text { Quantidade de } \\
\text { opções assinaladas }\end{array}$ & $\begin{array}{c}\text { Quantidade de } \\
\text { respostas }\end{array}$ \\
\hline 1 opção & 13 \\
2 opções & 13 \\
3 opções & 14 \\
4 opções & 10 \\
5 ou mais opções & 10 \\
Outras opções & 13 \\
Omissos & 9 \\
\hline
\end{tabular}

Fonte: Do autor

São muitas áreas com formas diversas de funcionamento e que devem ser previstas em um plano de segurança, de modo a evitar pontos de acesso ou de fuga da instituição. Como por exemplo, as lojas, lanchonetes e reprografias que podem ser comandadas por funcionários do quadro da própria instituição ou em alguns casos por entidades ou pessoas terceirizadas. Sendo assim, estes locais e suas características de funcionamento devem ser analisados para que não haja pontos falhos dentro do plano de segurança.

Com relação à segurança física que circunda a instituição, 12 (14,63\%) disseram ser gradeadas, 13 (15,85\%) muradas, 9 (11\%) cercadas e $13(15,85 \%)$ gradeadas e muradas, $3(3,66 \%)$ gradeado, murado e cercado e $1(1,22 \%)$ murado, cercado. Nesta questão houve uma grande quantidade de omissões com 22 instituições $(26,83 \%)$ não respondentes, podendo corresponder aos prédios que não possuem qualquer cercadura. Como é possível ver nas $9(11 \%)$ respostas da opção "outros": livre, portas, 12 seguranças, sem cercas, complexo de prédios que tomam um quarteirão, estrutura básica, décimo andar do prédio sede. Esta condição exige que as instituições reforcem sua segurança nas portas e janelas e no controle de acesso dos usuários, pois a instituição é privada de uma barreira física a mais.

Sobre a área de acesso à instituição as respostas à questão 5 mostram que 32 instituições $(39,02 \%)$ compartilham a área externa com outra instituição. Destas instituições que compartilham a área externa, 23 (71,87\%) possuem acesso comum. Este compartilhamento pode trazer falhas na segurança caso a outra instituição não 
tenha o mesmo rigor de vigilância da instituição guardiã de livros raros, além de poder prover áreas de fuga, acesso e esconderijo para um criminoso.

A maioria das instituições, no total de 44 (53,66\%), estão localizadas em prédios que foram construídos para a finalidade do seu uso atual. No entanto, é grande o número de instituições, $34(41,46 \%)$, que possuem prédios que foram construídos para outro objetivo. Houve $4(4,88 \%)$ omissões a essa questão. Esta adaptação pode influenciar na segurança dos livros raros, pois o ambiente pode não ser adequado para a proteção desse acervo. Das instituições que estão em prédios adaptados, metade sequer teve algum estudo ou projeto para adequação do ambiente para as atividades que são realizadas atualmente. A maioria das instituições ainda possui seus prédios tombados, num total de 45 (54,9\%); ou seja, essas instituições podem ter dificuldades na liberação de instalação ou na implementação de um sistema de segurança e vigilância que exija modificações físicas no ambiente, pois isto exigiria autorização do Iphan ou órgão local que efetuou o tombamento.

A área interna das instituições é dividida com outra organização em uma minoria das respondentes: em 21 (25,6\%) apenas. Mesmo assim, estas instituições devem prever, no plano de segurança, rotinas e procedimentos de circulação de pessoas.

\subsubsection{Dados sobre as Coleções de obras raras}

As coleções de livros raros, em sua maioria, funcionam em dois turnos, pois $60(73,8 \%)$ coleções estão abertas nos períodos da manhã e da tarde. 
Tabela 4 - Horário de funcionamento das Coleções de livros raros

\begin{tabular}{lc}
\hline $\begin{array}{c}\text { Horário de } \\
\text { Funcionamento }\end{array}$ & $\begin{array}{c}\text { Quantidade de } \\
\text { instituições }\end{array}$ \\
\hline Manhã & 2 \\
Manhã e tarde & 60 \\
Manhã, tarde e noite & 11 \\
Tarde & 4 \\
Tarde e noite & 2 \\
Omissos & 3 \\
\hline
\end{tabular}

Fonte: Do autor

Do total de respondentes, 44 (53,66\%) afirmam não possuir funcionários que atuem exclusivamente no setor de obras raras. Esta condição pode trazer sérios riscos à segurança contra roubo e furto de livros raros, pois pode significar a inexistência de um profissional especializado. Além disso, a falta de funcionário exclusivo no setor pode permitir que um grande número de serviçais tenha acesso ao acervo, caso não haja controle das pessoas que são permitidas a atender as necessidades de consulta. Duas (2,44\%) não responderam a questão e $36(43,9 \%)$ disseram ter funcionários exclusivos, em quantidade expressa na tabela abaixo.

Tabela 5 - Quantidade de funcionários nas Coleções de livros raros

\begin{tabular}{lccccc} 
& Bibliotecários & Estagiários & Terceirizados & Bolsistas & Voluntários \\
\hline Nenhum & 2 & 11 & 14 & 13 & 19 \\
$\mathbf{1}$ & 20 & 7 & 5 & 2 & 0 \\
$\mathbf{2 - 3}$ & 8 & 5 & 1 & 2 & 0 \\
$\mathbf{4 - 5}$ & 2 & 3 & 0 & 2 & 0 \\
$\mathbf{6 - 7}$ & 2 & 0 & 0 & 0 & 0 \\
$\mathbf{8 - 9}$ & 1 & 0 & 0 & 0 & 0 \\
Omissos & 1 & 10 & 16 & 17 & 17 \\
\hline \multicolumn{5}{r}{}
\end{tabular}

$\mathrm{Na}$ categoria "outros" foram apontados mais funcionários que também trabalham no setor de obras raras, tais como auxiliar de nível médio, conservador e restaurador, historiador, assistente administrativo, gestor cultural, entre outros.

As coleções de livros raros são de pequeno e médio porte, com 62 instituições (75,6\%) possuindo acervo com até 10.000 exemplares. A maior faixa, com 30 instituições $(36,6 \%)$, possui de 1.000 a 5.000 exemplares. 
Tabela 6 - Quantidade de exemplares nas Coleções de livros raros

\begin{tabular}{lc}
\hline Quantidade de exemplares & Quantidade de instituições \\
\hline Até 100 & 8 \\
$\mathbf{1 0 0 - 5 0 0}$ & 11 \\
$\mathbf{5 0 0 - 1 . 0 0 0}$ & 6 \\
$\mathbf{1 . 0 0 0 - 2 . 0 0 0}$ & 12 \\
$\mathbf{2 . 0 0 0 - 5 . 0 0 0}$ & 18 \\
$\mathbf{5 . 0 0 0 - 1 0 . 0 0 0}$ & 7 \\
$\mathbf{1 0 . 0 0 0 - 1 5 . 0 0 0}$ & 5 \\
$\mathbf{1 5 . 0 0 0 - 2 0 . 0 0 0}$ & 1 \\
Acima de 20.000 & 5 \\
Omissos & 9 \\
\hline
\end{tabular}

Fonte: Do autor

Quando questionadas sobre as condições de consulta do acervo, a ampla maioria, 75 (91,46\%), assinalou que esta é restrita. No entanto, ainda houve 6 instituições $(7,32 \%)$ que disseram que a consulta não é restrita; ou seja, isso mostra que em alguns poucos casos o usuário pode ter acesso direto ao acervo de livros raros, ou que os mesmo se encontram incluidos no acervo geral e, desta forma, a segurança das obras se torna comprometida. Uma instituição não respondeu a essa questão.

\subsubsection{Dados sobre segurança física das Coleções de obras raras}

Em 76 (92,68\%) instituições, o acervo de obras raras está separado do restante dos materiais, o que permite a elaboração de um programa de segurança específico para esta coleção e para o local onde a mesma se encontra. Das outras 6 $(7,32 \%)$ que responderam não haver esta separação, apenas duas disseram também não haver uma restrição de acesso.

A maioria das instituições não possui reforço extra nas paredes, totalizando 68 (82,93\%), a mesma quantidade que não possui cofre para abrigar a coleção ou parte dela, enquanto $14(17,07 \%)$ responderam ter reforço extra na parede e a mesma quantidade disse também ter cofre. A adoção de cofres nas coleções de livros raros faz com que o acervo ou parte dele esteja mais protegido dentro de um 
ambiente com estrutura mais rígida e com acesso controlado por senha. Neste caso, são poucas as instituições que adotam essa ferramenta de segurança.

Sobre o material usado no teto acima do acervo, a maioria, 64 (78,05\%) respondeu ser laje, enquanto 13 (15,85\%) responderam ter forro de gesso, madeira ou PVC sob telhas. Uma resposta informou ter forro de madeira, mas não apresentou qual material está acima dele, enquanto outra informou ter como teto um combinado de telhas, forro, madeira, isopor e placas de alumínio. Houve três abstenções de resposta a essa pergunta. Portanto, a maioria das instituições está razoavelmente protegida contra invasões que poderiam acontecer pelo teto, já que a laje é uma estrutura rígida que impõe dificuldades à sua transposição.

A questão 21 indaga sobre a visão do salão de leitura pelos funcionários do setor de obras raras. A maior parte, 56 (68,29\%), das instituições respondeu que seus funcionários têm visão do salão de leitura; no entanto, a quantidade de organizações em que o pessoal não tem essa visão é grande, totalizando 22 $(26,83 \%)$. A ausência de vigilância no momento da consulta pode permitir que usuários mal intencionados se apropriem de algum livro ou de parte dele, como, por exemplo, é facilitado o furto de gravuras, já que a retirada de uma ou algumas poucas páginas no meio de tantas outras, em um livro, pode passar despercebido de imediato, no momento da devolução do material. Houve 4 (4.88\%) omissões de respostas.

As portas do setor de obras raras são consideradas resistentes por 45 $(54,88 \%)$ instituições. As outras $37(45,12 \%)$ não consideram as portas resistentes. Além da resistência da porta em si, podem ser adicionados outros elementos que ajudam a dificultar a invasão, como o uso de trancas, cadeados e grades, entre outros. Quanto ao uso deste reforço de proteção às portas, houve $5(6,1 \%)$ omissões de resposta e 23 (28,05\%) não usam qualquer proteção extra. Das instituições que assinalaram uma única opção de reforço, 18 (21,95\%) disseram usar apenas a tranca, 6 (7,32\%) o cadeado, 7 (8,54\%) o ferrolho e 1 (1,22\%) a grade. Na opção "outros", 8 instituições (9,75\%) colocaram como reforços de suas portas barra de madeira, chave tetra, cadeado e fechadura com chave, entre outros. 
Outras 14 instituições (17,07\%) assinalaram usar mais de um reforço, de acordo com a tabela abaixo:

Tabela 7 - Reforços nas portas

\begin{tabular}{|c|c|}
\hline Opções & $\begin{array}{c}\text { Quantidade de } \\
\text { Respostas }\end{array}$ \\
\hline Cadeado e tranca & 2 \\
\hline $\begin{array}{l}\text { Cadeado, grade, } \\
\text { ferrolho, tranca, } \\
\text { corrente e alarme }\end{array}$ & 1 \\
\hline Ferrolho e tranca & 5 \\
\hline Grade e cadeado & 4 \\
\hline $\begin{array}{l}\text { Grade, ferrolho e } \\
\text { Tranca }\end{array}$ & 1 \\
\hline Tranca e vigilância & 1 \\
\hline
\end{tabular}

As janelas foram consideradas mais resistentes que as portas por um número maior de instituições, totalizando $55(67,07 \%)$. No entanto, ainda foi grande o número de organizações que não acham resistentes as janelas que circundam a coleção de obras raras, somando $24(29,27 \%)$. As outras 3 respondentes $(3,66 \%)$ disseram não possuir janelas na área do acervo de livros raros. Quanto à proteção extra nas janelas, 25 instituições $(30,49 \%)$ disseram não usar qualquer uma. Houve $10(12,19 \%)$ casos omissos, enquanto $17(20,73 \%)$ usam grade, $13(15,85 \%)$ tranca, $3(3,66 \%)$ ferrolho e $2(2,44 \%)$ cadeado. Foram $6(7,32 \%)$ instituições as que marcaram mais de uma opção de reforço extra, 6 (7,32\%) usaram a opção "outro", 3 disseram não possuir janelas neste ambiente e as outras 3 disseram usar barra de madeira, tranca, tela e câmeras.

Ao analisar as questões 22 e 24 simultaneamente é possível ver que a maioria das instituições, no total de $39(47,56 \%)$, possuem tanto portas quanto janelas resistentes. Contudo, é alto o número de instituições que não possuem qualquer das duas estruturas de segurança física com resistência para proteção do acervo, totalizando $20(24,39 \%)$ instituições, número igual ao de coleções que só possuem uma das estruturas resistentes, sendo que $4(4,88 \%)$ consideram apenas as portas resistentes e $16(19,51 \%)$ somente as janelas. Ainda houve $3(3,66 \%)$ 
instituições que responderam apenas uma dessas duas questões. A precariedade das portas e janelas pode ser agente influenciador da decisão do criminoso em roubar ou furtar um livro raro, já que estas estruturas não trarão muita resistência à invasão, pois o grau de dificuldade de arrombamento pode permitir que, durante a ação, os criminosos sejam descobertos antes de completar o roubo ou furto, sendo impedidos do mesmo.

As exposições de livros raros são feitas em 45 (54,88\%) respondentes, enquanto $36(43,9 \%)$ não fazem e uma não respondeu. Das instituições que disseram fazer exposições, 39 (86,66\%) consideram seus expositores resistentes, enquanto $5(11,11 \%)$ não consideram e uma não respondeu.

Analisando as variáveis independentes sobre segurança física aplicada nas coleções de obras raras, verificadas nas questões 18, 19, 21, 22 e 24 que interrogam sobre a existência de reforço extra nas paredes que circundam a coleção, a presença de cofre, a visão dos funcionários sobre o salão de leitura e a resistência das portas e janelas do setor de obras raras, é possível ver que a quantidade de instituições que responderam negativamente a todas as questões supera o número das que responderam todas positivamente, sendo $5(6,1 \%)$ instituições negativamente e $3(3,66 \%)$ positivamente. Ao todo, 7 (8,54\%) deixaram pelo menos uma das 5 questões sem resposta. A tabela abaixo mostra a incidência de respostas positivas às 5 questões.

Tabela 8 - Quantidade de respostas positivas nas questões sobre segurança física

\begin{tabular}{lc}
\cline { 2 - 2 } & Quantidade de respostas \\
\hline Não respondeu a todas as questões & 7 \\
Nenhuma resposta positiva & 5 \\
1 resposta positiva & 18 \\
$\mathbf{2}$ respostas positivas & 20 \\
$\mathbf{3}$ respostas positivas & 17 \\
$\mathbf{4}$ respostas positivas & 12 \\
Todas as respostas positivas & 3 \\
\hline
\end{tabular}

Fonte: Do autor 
A maioria das instituições que responderam às 5 perguntas, $43(57,33 \%)$ marcaram menos da metade das perguntas como positivas; ou seja, de 5 processos de segurança física levantados, a maioria das instituições adota, no máximo, 2, sendo que os processos mais citados pelas respondentes é a visão do salão de leitura por seus funcionários e janelas resistentes. Portanto, as instituições devem conduzir os seus esforços para a adoção de reforço extra nas paredes que circundam a coleção, a compra ou criação de cofres ou salas cofres para maior proteção de seu acervo mais valioso e o aumento da segurança nas portas que dão acesso ao seu acervo, por meio da escolha de um material de fabricação mais reforçado e do uso de equipamentos extras que ajudem as portas a ser uma barreira física que impeça a entrada de criminosos.

\subsubsection{Dados sobre segurança eletrônica nas Coleções de obras raras}

As instituições foram indagadas sobre o uso de 4 tipos de equipamentos eletrônicos: câmeras, detectores de movimento, alarmes e trancas eletrônicas. Os dados sobre estas questões estão na tabela abaixo:

Tabela 9 - Uso de equipamentos eletrônicos

\begin{tabular}{lccc}
\hline \multicolumn{1}{c}{ Equipamentos } & Usa & Não usa & Não respondeu \\
\hline Câmeras & 38 & 43 & 1 \\
$\begin{array}{l}\text { Detectores de } \\
\text { movimento }\end{array}$ & 16 & 62 & 4 \\
$\begin{array}{lcc}\text { Alarmes } \\
\text { Trancas eletrônicas }\end{array}$ & 17 & 61 & 4 \\
\hline & Fonte: Do autor & 4 \\
\hline
\end{tabular}

A maioria das coleções de obras raras são desprovidas de qualquer equipamento eletrônico que ajude na detecção de invasão ao acervo, ou que identifique ações criminosas ocorridas no passado ou que estão acontecendo naquele momento; assim como não têm dispositivo eletrônico nas trancas que possam ajudar a restringir o acesso ao acervo e identificar quem efetuou a abertura das portas, já que esses equipamentos permitem a emissão de chaves ou cartões 
com informações de cada indivíduo que os possui, além de alguns funcionarem com leitores biométricos.

O ideal no uso das câmeras de vigilância é que as mesmas possuam visão noturna, para que seja possível identificar as ações e os indivíduos em ambientes com pouca iluminação, como é o caso da maioria das instituições, 21 (55,26\%), que usam este equipamento. No entanto, é grande o número de coleções, 17 (44,74\%), em que as câmeras não possuem esta função, o que delimita a eficácia das mesmas no plano de segurança. Outro dado importante é saber que 28 (73,68\%) das 38 que usam câmeras não gravam as imagens ou as descartam periodicamente, situação que não é a ideal, pois muitos crimes, principalmente os que envolvem a participação de pessoas que trabalham com o acervo, só são descobertos algum tempo depois da ação, o que, em alguns dos casos, pode impedir que se identifique quem foi o criminoso, já que as imagens podem não estar disponíveis. Apenas 12 $(31,38 \%)$ instituições que têm câmeras fazem o monitoramento das mesmas $24 \mathrm{~h}$ por dia. Os modos de uso, monitoramento e gravação das câmeras obtiveram 8 variações de respostas de acordo com a tabela abaixo:

Tabela 10 - Uso das câmeras de segurança

\begin{tabular}{lc}
\hline \multicolumn{1}{c}{ Usos } & $\begin{array}{c}\text { Quantidade de } \\
\text { respostas }\end{array}$ \\
\hline Gravadas e descartadas periodicamente & 17 \\
Gravadas e armazenadas por tempo indeterminado & 4 \\
Monitoradas pela equipe de segurança durante o funcionamento do setor & 1 \\
Monitoradas pela equipe de segurança durante o funcionamento do setor, & 4 \\
Monitoradas pela equipe de segurança 24 horas & 1 \\
Gravadas e descartadas periodicamente, Monitoradas pela equipe de & \\
segurança durante o funcionamento do setor, Monitoramento remoto pela \\
chefia de segurança e biblioteca
\end{tabular}

Fonte: Do autor

Quando analisadas as variáveis independentes presentes nas questões 28, 31, 32 e 33 que levantam o uso de câmeras, detectores de movimento, alarmes e 
trancas eletrônicas, a quantidade de respostas positivas a estes itens ficou conforme a tabela abaixo:

Tabela 11 - Quantidade de respostas positivas nas questões sobre segurança eletrônica

\begin{tabular}{lc}
\cline { 2 - 2 } & Quantidade de respostas \\
\hline Não respondeu a todas as questões & 5 \\
Nenhuma resposta positiva & 33 \\
1 resposta positiva & 25 \\
$\mathbf{2}$ respostas positivas & 10 \\
3 respostas positivas & 9 \\
Todas as respostas positivas & 0 \\
\hline
\end{tabular}

Fonte: Do autor

É muito alto o número de respondentes que não possuem qualquer equipamento eletrônico para proteção de seu acervo. Portanto, estas instituições contam apenas com as barreiras físicas, com sua equipe e o plano de segurança. Apenas 19 (23,17\%) instituições, de 82, têm mais de um dispositivo eletrônico para vigilância das obras raras. Nenhuma coleção tem instalados os 4 dispositivos averiguados. A situação ainda é pior ao se verificar as respostas quanto à existência de plano de manutenção dos equipamentos. Das 44 respondentes que marcaram ao menos uma das 4 respostas como positiva, mesmo que não tenham respondido a todas as questões, 33 (75\%) responderam a questão 35 sobre o plano de manutenção, onde 17 (38,64\%) disseram ter o plano e 16 (36,37\%) disseram não ter; ou seja, praticamente metade das respondentes da questão 35 não têm plano de manutenção de seus equipamentos eletrônicos, o que significa que eles podem sequer estar funcionando, ou ficar por muito tempo sem funcionamento. Isto acontece, por exemplo, com os alarmes, que, por não serem frequentemente acionados, podem ficar sem funcionar e a instituição não perceber. 


\subsubsection{Dados sobre as equipes de segurança e guarda de chaves}

As questões de número 37 a 40 são relacionadas aos programas adotados quanto às chaves que dão acesso ao acervo de livros raros. A maioria respondeu positivamente, ou seja, que possuem programa de controle de chaves, programa de reposição e duplicação das mesmas, que fazem controle de emissão das chaves e cartões magnéticos e que registram as perdas. No entanto, foi considerada alta a quantidade de instituições que responderam negativamente às questões, pois estes são processos que não envolvem muitos gastos, como no caso da instalação de equipamentos eletrônicos, mas refletem a importância que a instituição dá à segurança ao seu acervo, fazendo o controle das atividades que envolvem o uso das chaves de acesso à coleção. Portanto, as respostas às questões mostram que não é preciso somente o investimento financeiro maciço para segurança do patrimônio público, mas também uma mudança cultural dentro das próprias instituições guardiãs.

Tabela 12 - Controle de chaves

\begin{tabular}{lccc}
\hline \multicolumn{1}{c}{ Perguntas } & Sim & Não & Omissos \\
\hline Existe uma política de controle de chaves? & 59 & 21 & 2 \\
Existe uma política de reposição e duplicação de chaves? & 42 & 37 & 3 \\
$\begin{array}{l}\text { A emissão de chaves e cartões magnéticos de identificação é } \\
\text { controlada? }\end{array}$ & 53 & 22 & 7 \\
A perda de chaves é registrada? & 64 & 13 & 5 \\
\hline
\end{tabular}

Fonte: Do autor

A maioria das instituições afirmou ter uma equipe de segurança, 61 (74,39\%), enquanto $19(23,17 \%)$ não possuem e 2 (2,44\%) não responderam a essa questão. No entanto, apesar do alto número de instituições que têm equipe de segurança, mais de 2/3, 41 (67,21\%), não treinaram suas equipes para agir quando houver roubo ou furto à coleção de livros raros. Das 61 instituições que têm equipe de segurança, 41 (67,21\%) consideram o número de pessoas nesta equipe suficiente, em $55(90,16 \%)$ a equipe faz ronda pela instituição e 34 (55,74\%) realizam treinamento periódico com o pessoal da segurança. Apesar do alto índice de respostas positivas às questões relacionadas à equipe de segurança, o número de 
respostas negativas também é alto, já que 19 (31,17\%) organizações não consideram a quantidade de pessoas em sua equipe de segurança suficiente e 26 $(42,62 \%)$ não realizam treinamento periódico. Das instituições que possuem equipe de segurança, em apenas $6(9,84 \%)$ esta equipe não faz ronda pela instituição. No entanto, as 6 instituições disseram não possuir quantidade suficiente de pessoal em sua equipe de segurança, o que pode indicar que o investimento em uma maior quantidade de seguranças eleva a qualidade do serviço destas equipes em pelo menos um aspecto.

\subsubsection{Dados sobre o controle do acervo}

Em 51 (62,2\%) instituições, seus livros raros estão catalogados, e nas 31 $(37,8 \%)$ que não têm todo o acervo raro catalogado, 22 (70,97\%) não utilizam a linguagem GW ou fotobibliografia para o controle do acervo, o que não significa que não usem outros meios para listá-lo.

A maioria das instituições, 66 (80,49\%), já fez inventário, mas quase a metade, 31 (46,97\%), não faz periodicamente, o que pode fazer com que existam casos de desaparecimento de livros raros ignorados pela instituição.

As consultas bibliográficas especializadas para conhecimento da importância histórica dos seus livros são realizadas em 55 (67,07\%) das instituições, enquanto $24(29,27 \%)$ não o fazem e $3(3,66 \%)$ não responderam. A maioria também faz análise bibliológica, onde são levantadas todas as características dos exemplares que ajudam em sua individualização, totalizando $40(48,78 \%)$ as que fazem e 38 $(46,34 \%)$ as que não fazem, além das $4(4,88 \%)$ que não responderam à questão.

Uma ampla maioria das instituições, 73 (89,02\%), faz algum tipo de controle dos usuários que acessam seus livros raros. Mesmo assim, 7 (8,54\%) não fazem e 2 $(2,44 \%)$ foram os casos omissos. Na questão 54 foram questionados os métodos de controle de usuários adotados por cada instituição e foram dadas 7 opções de marcação: apresentação de documento de identificação pessoal (35), anotação de dados pessoais do usuário, cadastro de usuário em sistema automatizado da 
biblioteca (30), controle da quantidade de livros consultados por vez (40), anotação manual dos títulos consultados (34), controle dos títulos cadastrados pelo sistema automatizado da biblioteca (25) e agendamento da consulta (29), além da opção "outros", onde o respondente poderia colocar uma opção diferente das sete já contempladas no questionário. Os respondentes poderiam marcar mais de uma opção e por isso houve 42 respostas diferentes, mostrando o quão diversificados são os sistemas de controle de usuários nas instituições guardiãs de livros raros. Houve 2 casos omissos nessa questão. Na tabela abaixo é possível ver quantos recursos são adotados pelas instituições para fazer o controle de acesso do usuário ao seu acervo.

Tabela 13 - Quantidade de opções marcadas na questão sobre métodos de controle de usuários

\begin{tabular}{lc}
\hline Quantidade de opções & Quantidade de repostas \\
\hline 1 opção & 10 \\
2 opções & 12 \\
3 opções & 10 \\
4 opções & 10 \\
5 opções & 12 \\
6 opções & 11 \\
7 opções & 0 \\
Opção "outros" & 6 \\
Omissos & 2 \\
\hline
\end{tabular}

Fonte: Do autor

Nenhuma instituição marcou as 7 opções e, das 6 instituições que marcaram a opção outros, 4 marcaram também algumas opções que já estavam no questionário. Uma destas instituições disse que as obras não estão disponíveis para consulta; outra disse também exigir carta de apresentação da instituição interessada na pesquisa; em outra delas é perguntado o objetivo da pesquisa; outra detalhou que o agendamento é feito por e-mail; uma disse que o usuário não entra na sala do acervo; outra instituição acrescentou às opções pré-existentes, apenas: sistema de controle do usuário, sem dar mais detalhes sobre o que isso significa. As opções mais marcadas foram anotações de dados pessoais, assinalada por 47 instituições; 
controle da quantidade de livros consultados por vez, por 40 instituições; e apresentação de documento de identificação pessoal, por 35 instituições.

Tabela 14 - Métodos de controle de usuários

\begin{tabular}{lc}
\hline \multicolumn{1}{c}{ Opções } & $\begin{array}{c}\text { Quantidade de } \\
\text { instituições }\end{array}$ \\
\hline Apresentação de documento de identificação pessoal & 35 \\
Anotação de dados pessoais do usuário & 47 \\
Cadastro de usuário em sistema automatizado da biblioteca & 30 \\
Controle da quantidade de livros consultados por vez & 40 \\
Anotação manual dos títulos consultados & 34 \\
Controle dos títulos cadastrado pelo sistema automatizado & 25 \\
da biblioteca & \\
Agendamento da consulta & 29 \\
\hline
\end{tabular}

Fonte: Do autor

A questão 54 mostra que as instituições, de modo geral, preocupam-se em controlar como e o que os usuários consultam. O que pode aumentar é o uso dos sistemas de automação das bibliotecas para fazer o cadastro dos usuários e o controle dos livros que estão com eles, para que, em caso de roubo ou furto, seja rápida a identificação dos possíveis suspeitos, pois, fazendo isso manualmente, pode haver casos em que nem todos os títulos sejam anotados e também aqueles em que sejam gerados mais de um documento para um mesmo usuário, no caso de consultas espaçadas por um longo período.

Quanto à digitalização do acervo, 56 (68,29\%) instituições não a realizam, enquanto apenas $25(30,49 \%)$ digitalizam seus livros raros. Houve uma abstenção à questão. Menor ainda é a quantidade de instituições que fazem a microfilmagem, totalizando 7 (8,54\%), com uma omissão de resposta. Portanto, 74 (90,24\%) instituições não realizam a microfilmagem da coleção; ou seja, com um possível roubo ou furto do livro impresso, a informação pode também se perder, já que o registro em outro suporte não é realizado com frequência pelas guardiãs de livros raros; assim como não seria possível recuperar as informações no caso de uma catástrofe ou qualquer outro motivo que ocasione a perda do objeto livro. 
A integridade dos livros após a consulta é verificada em 51 (62,19\%) instituições. No entanto, é grande a quantidade de instituições, 28 (34,15\%), que não fazem verificação para saber se os livros estão sendo devolvidos nas mesmas condições em que foram entregues aos usuários. Houve 3 (3,66\%) abstenções. Esta situação permite que os usuários se apropriem de parte da obra ou mesmo da obra inteira, como em alguns casos em que os criminosos devolvem o livro consultado, mas do original só se mantém a capa, pois o miolo é trocado. Nestes casos, a descoberta do furto poderá acontecer muito tempo depois do ocorrido, provavelmente quando outro usuário solicitar o livro para consulta e identificar a ausência do original. As instituições que disseram fazer a averiguação pós-consulta dizem, em sua maioria, que é feita a análise manual do material, a verificação da integridade dos livros, se há anotações manuais e a contagem das páginas. Algumas instituições salientaram que funcionários permanecem junto aos usuários durante a pesquisa e também é feito o monitoramento da consulta por câmeras. Outro fator que aumenta a possibilidade de roubo e furto de partes do livro e a demora de sua descoberta é a ausência de uma listagem dos livros que possuem gravuras originais, pois estas têm considerável valor de mercado e podem ser facilmente retiradas sem que isso seja notado, caso não ocorra uma minuciosa averiguação de integridade. Em 60 (73,17\%) das respondentes não há uma listagem dos livros da coleção que possuem gravuras originais, ferramenta que só é usada em 19 (23,17\%) das instituições. Nessa questão houve 3 (3,66\%) não respondentes.

O seguro contra roubo ou furto dos livros não é feito em 62 (75,61\%) instituições, enquanto 17 (20,73\%) pagam seguro para o seu acervo raro e 3 $(3,66 \%)$ não responderam à questão. O seguro é um recurso que não evita a perda histórica e informacional causada pelo roubo e furto do livro, mas pode servir para uma reposição patrimonial à instituição, além de permitir a compra de outro material importante, ou mesmo de outro exemplar do título levado, caso exista outro disponível à venda.

Na maioria das instituições, 56 (68,29\%), não existem normas de acesso ao acervo em momentos de não atendimento ao público, enquanto 20 (24,39\%) instituições possuem tais normas e 6 (7,32\%) não responderam. O acesso não 
controlado ao acervo nos horários em que o setor está fechado aumenta a possibilidade de apropriação indevida dos livros raros, pois não há restrição de funcionários que possam fazer estes acessos excepcionais, assim como não há uma lista de possíveis eventos em que estes acessos possam ocorrer nem uma forma padronizada de notificar tais acessos.

Do ponto de vista da segurança contra roubo e furto de livros raros, é justificável e até indicado o uso de marcas de propriedade definitivas, como visto em Gauz (1994; 2004) e no ACRL/RBMS Guidelines... (2009). No entanto, do ponto de vista da preservação de objetos bibliográficos, a adoção dessas marcas pode representar um risco ao acervo, pois a aplicação de marca permanente no livro raro altera a integridade e originalidade do objeto, o que acarreta em perda patrimonial. $O$ uso de carimbos com tinta também é prejudicial, pois as instituições podem não atentar para suas características de produção, como, por exemplo, o índice de acidez da tinta e sua resistência à umidade para que não borre; assim como os carimbos a seco, que fazem uma marca em relevo, e com frequência rompem as fibras do papel, de modo que o efeito futuro é a soltura de pedaços ao redor da marca. Também não há como impedir que no caso de roubo e furto os carimbos sejam removidos das obras perdendo sua funcionalidade. O uso de etiquetas na lombada, por sua vez, não é recomendado do ponto de vista da preservação, devido à presença de colas que são prejudiciais ao couro e ao papel. Mesmo as filipetas de papel livre de acidez não são marcas de propriedade relevantes no âmbito da segurança, pois não são marcas permanentes, sendo de fácil remoção. Portanto, o presente trabalho não recomenda o uso de marcas de propriedade de qualquer espécie. Em 63 (76,83\%) das instituições são adotadas as marcas de propriedade, enquanto as outras $19(23,17 \%)$ respondentes não as usam. As instituições que usam unicamente o carimbo a tinta como marca somam $15(18,29 \%)$, enquanto as que usam o carimbo a tinta associado com etiqueta na lombada são 21 (25,61\%). Como a questão 63 permitia a marcação de mais de uma opção, o uso de carimbo a tinta aparece em 51 (62,19\%) das 82 respostas. O uso de etiquetas na lombada aparece em 35 (42,68\%). Houve uma omissão e 6 (7,32\%) respondentes fizeram uso da opção "outros", onde o que foi colocado além das opções sugeridas à questão foram marcas não permanentes, como o uso de filipetas de papel com $\mathrm{Ph}$ 
neutro, cartão com etiqueta de identificação e registro, etiquetas coladas em tira de papel e marcador de páginas com dados do exemplar. Na opção "outros" apenas uma instituição relatou o uso de etiquetas antifurto.

Tabela 15 - Marcas de propriedade

\begin{tabular}{lc}
\hline \multicolumn{1}{c}{ Marca de propriedade } & $\begin{array}{c}\text { Quantidade de } \\
\text { respostas }\end{array}$ \\
\hline Carimbo a tinta & 15 \\
Etiquetas na lombada & 5 \\
Ex libris & 2 \\
Outros & 6 \\
Não respondido & 1 \\
Carimbo a tinta, Carimbo em relevo & 1 \\
Carimbo a tinta, Carimbo em relevo, Etiquetas na lombada & 1 \\
Carimbo a tinta, Carimbo em relevo, Etiquetas na lombada, & 3 \\
Ex libris & \\
Carimbo a tinta, Etiquetas na lombada & 21 \\
Carimbo a tinta, Etiquetas na lombada, Ex libris & 3 \\
Carimbo a tinta, Ex libris & 4 \\
Carimbo em relevo, Etiquetas na lombada & 1 \\
\hline
\end{tabular}

Fonte: do autor

O plano de emergência deve ser elaborado para que a equipe saiba exatamente como proceder, caso todas as medidas de segurança não evitem o roubo ou furto. Em 75 (91,46\%) instituições, não existe plano de emergência, enquanto apenas $6(7,32 \%)$ têm. Houve uma instituição não respondente. Das instituições que possuem plano de emergência, apenas 3 (50\%) deram algum tipo de detalhe de quais são os procedimentos adotados, como a comunicação via rádio dos seguranças para impedir que o criminoso saia do prédio, utilização das câmeras para identificação dos responsáveis e comunicação à reitoria, que repassa para seu setor jurídico; ou seja, o plano de emergência não prevê uma comunicação com as entidades policiais e com livreiros ou colecionadores a fim de evitar que seja repassado o material roubado.

Também não foi realizado na maioria das instituições, 61 (74,39\%), um gerenciamento de risco, a fim de estabelecer quais são os maiores riscos a que o acervo está sujeito e uma lista de prioridades de ação. Apenas 17 (20,73\%) 
instituições já fizeram o gerenciamento de risco e 4 (4,88\%) não responderam à questão.

Na maioria das instituições, 44 (53,6\%), não existe um setor de restauração, enquanto em 36 (43,90\%) há um setor específico para realizar a restauração das obras raras e $2(2,44 \%)$ não responderam a questão. Quanto à existência ou não de um controle formal na transferência dos livros raros do seu setor para restauração, a maioria, 42 (51,22\%), disse que há este controle. No entanto, o número de instituições que não fazem um controle formal é muito grande, totalizando 33 $(40,24 \%)$, com 7 (8,54\%) omissões de resposta. Das instituições que não fazem controle da transferência de obras do seu setor de origem para a restauração, em apenas $5(15,15 \%)$ este segundo setor está na própria instituição, o que é preocupante, pois pode haver casos de roubo e furto nesta transferência e não haver relato da transferência da obra; ou seja, em 28 (84,85\%) instituições que não realizam um controle formal de transferência o setor de restauração não está na própria instituição. De modo que a obra sai da própria instituição e não há um controle formal sobre esta saída, nem sobre a chegada no local onde será realizada a restauração. Portanto, fica facilitada a apropriação indevida das obras neste percurso, pois a instituição não tem como provar a saída do material e o recebimento em outro local. A questão 69, ainda ligada à segurança envolvendo o setor de restauração, mostra que em 28 (34,15\%) a segurança é a mesma do setor de origem da obra, enquanto em 23 (28,05\%) não há a mesma segurança. Houve 31 $(37,80 \%)$ omissões de resposta à questão.

Quanto ao empréstimo de exemplares do acervo de obras raras para outras instituições, 57 (69,51\%) das instituições respondentes nunca realizaram empréstimo, enquanto 21 (25,61\%) já realizaram e 4 (4,88\%) não responderam à questão. Das 21 instituições que fizeram o empréstimo de livros raros para outra instituição, 18 (85,71\%) enviaram alguém do seu quadro de funcionários para acompanhar as obras, enquanto 3 (14,29\%) não enviaram. Foi igual o número de instituições que fizeram seguro das que não fizeram, 10 (47,62\%), enquanto 1 $(4,76 \%)$ não respondeu a questão. Neste contexto, é possível ver que as instituições geralmente não realizam empréstimo dos livros raros, mas quando emprestam nem 
sempre realizam o seguro, que, apesar de não reverter a perda daquela obra específica, pode permitir que outro exemplar da mesma obra, caso exista a venda, seja adquirido para seu acervo, ou mesmo outra obra que interesse à instituição. Apesar da perda histórica ser inevitável, neste caso, ao menos não há uma perda patrimonial considerável.

As instituições foram questionadas sobre a existência de um plano formal de segurança para o setor de obras raras; a grande maioria, 65 (79,27\%), disse não ter um plano de segurança formalizado, enquanto $14(17,07 \%)$ têm e $3(3,66 \%)$ não responderam; ou seja, mesmo que possuam um sistema eletrônico de segurança contra roubo e furto, uma boa estrutura física que aja como barreira resistente às investidas criminosas, uma equipe com pessoal suficiente e treinamento para ação imediata na descoberta do crime, um conhecimento muito grande sobre o acervo, um profissional qualificado na gestão do setor de obras raras, mas não tenha um plano formal que trace exatamente como devem agir todos os agentes envolvidos na segurança contra roubo e furto, a instituição está vulnerável a este crime. Um exemplo do que pode ocorrer é a equipe de funcionários não respeitar as regras estipuladas para segurança, que, com o tempo, podem se perder por não estarem formalizadas. Das 14 instituições que possuem um plano formal de segurança, 13 $(92,86 \%)$ disseram que todos os funcionários a conhecem, enquanto em uma eles não têm esse conhecimento.

Quando questionadas sobre a existência de algum caso de desaparecimento de livros raros do setor de obras raras, 54 (65,85\%) instituições disseram não ter qualquer registro deste tipo de evento. Mas, apesar de não ser a maioria, o número de instituições que já registraram casos de desaparecimento de livros raros é grande, totalizando 21 (25,61\%) das instituições, enquanto houve 7 (8,54\%) omissões. A essas instituições foi aplicado um novo questionário sobre as condições em que ocorreram esse desaparecimento, e o resultado desta outra pesquisa é apresentado na segunda etapa da análise de dados. 


\subsubsection{Dados sobre os responsáveis pelas coleções de obras raras}

Os(as) responsáveis pelas coleções de livros raros, em sua maioria, possuem graduação em Biblioteconomia: 36 cursaram Biblioteconomia, mas indicaram não possuir pós-graduação, seja lato sensu ou strictu sensu. Das 27 instituições que responderam que o(a) responsável possui pós-graduação lato sensu, 12 disseram ter feito Biblioteconomia e das 7 que disseram que o responsável tem mestrado, 2 fizeram Biblioteconomia; ou seja, dos 82 respondentes, 50 (60,97\%) possuem graduação em Biblioteconomia, enquanto $1(1,22 \%)$ tem apenas o ensino médio, 7 $(8,54 \%)$ têm outra graduação, $20(24,39 \%)$ só indicaram a pós-graduação que possuem sem falar qual é sua graduação, $1(1,22 \%)$ respondeu apenas que a pessoa que cuida do setor de conservação cuida de todo o acervo, não indicando qualquer graduação e $3(3,66 \%)$ não responderam à questão.

Tabela 16 - Formação do responsável pela Coleção de livros raros

\begin{tabular}{lcc}
\hline \multicolumn{1}{c}{ Formação Inicial } & Formação Complementar & Total \\
\hline Ensino médio & - & 1 \\
\hline \multirow{2}{*}{ Biblioteconomia } & Sem pós-graduação & 36 \\
& Especialização & 12 \\
& Mestrado & 2 \\
& Doutorado & 0 \\
\hline \multirow{2}{*}{ Outra graduação } & Sem pós-graduação & 3 \\
& Especialização & 2 \\
& Mestrado & 3 \\
\hline \multirow{3}{*}{ Graduação não indicada } & Doutorado & 0 \\
& Especialização & 13 \\
\hline Não respondentes & Mestrado & 5 \\
Outra resposta & Doutorado & 2 \\
\hline
\end{tabular}

Fonte: Do autor

Todos os respondentes disseram ter ao menos uma chefia acima do responsável pela Coleção de obras raras, o que significa que os responsáveis por esta coleção não são, em qualquer dos casos, os responsáveis por toda a instituição, de modo que é possível que os mesmos se dediquem exclusivamente às questões relacionadas ao acervo raro e que tenham com quem dividir as 
responsabilidades, já que as chefias também são responsáveis pela segurança dos livros raros.

As instituições responderam que a maioria dos responsáveis pela Coleção de obras raras, $52(63,41 \%)$, não possuem curso sobre segurança contra roubo e furto de acervos raros, enquanto $23(28,05 \%)$ têm algum curso sobre o tema e 7 (8,54\%) não responderam à questão. Neste caso, os próprios responsáveis pela Coleção de livros raros não estão preparados para lidar com possíveis casos de roubo e furto, além de não estarem também preparados para estabelecer as rotinas e o plano de segurança da sua instituição, por falta de conhecimento.

Quanto ao fato do responsável estar no setor durante todo o seu horário de funcionamento, 41 (50\%) ficam, 35 (42,68\%) não ficam e 6 (7,32\%) não responderam. Portanto, em algumas instituições o responsável não permanece durante todo o funcionamento do setor, não tendo controle sobre tudo que está sendo feito com o acervo, fator que reforça o uso de câmeras de segurança que controlam as atividades, desde que permitam acessar as imagens futuramente em caso de desconfiança de qualquer problema na gestão do acervo, ou de roubo e furto dos livros raros.

$\mathrm{Na}$ última questão, de número 80 , foi dado espaço para o respondente colocar comentários, críticas, depoimentos e observações sobre algo que não tenha sido contemplado nas questões anteriores. Houve $42(51,22 \%)$ respondentes à questão e 40 (48,78\%) não respondentes. Das respondentes, 20 (47,62\%) fizeram considerações sobre as características do seu acervo e da sua própria instituição, como, por exemplo, a organização estrutural e onde a biblioteca e o acervo de livros raros está situado, a abrangência do acervo quanto ao assunto, o período de publicação das obras, aspectos sobre a conservação, a proveniência dos exemplares, entre outros aspectos. Os mesmos não serão apontados minuciosamente neste trabalho por não ser este o objetivo da pesquisa e para não levantar qualquer característica que possa identificar os respondentes, como medida de segurança e respeito às instituições. 
No total de 8 (19,05\%) instituições deram respostas que detalham melhor a sua segurança contra roubo e furto, como posicionamento de câmeras, restrições de acesso ao acervo, quantidade de pessoal na equipe de segurança, entre outros aspectos. Um total de 3 (7,14\%) respondentes disseram ainda estar desenvolvendo sua coleção de obras raras. Houve $2(4,76 \%)$ instituições que usaram o espaço da questão 80 para descrever o grau de formação do responsável pela coleção, assim como também outras $2(4,76 \%)$ respondentes descreveram sucintamente situações de desaparecimento de livros raros. Houve elucidação de problemas de ambiguidade nas questões e pedido de inserção de outras perguntas ao questionário por 2 (4,76\%) instituições. No entanto, 3 (7,14\%) respondentes elogiaram a pesquisa e o questionário. Das respondentes, 2 (4,76\%) disseram não poder responder a todo o questionário por questões de segurança. Essas respostas refletem uma das dificuldades enfrentadas pela pesquisa, já que muitas instituições disseram direta e indiretamente que não participariam da pesquisa com medo de expor seus esquemas de segurança ou a ausência destes.

\subsubsection{Análise das condições gerais de segurança nas instituições respondentes}

$\mathrm{Na}$ observação de algumas variáveis independentes, onde a opção de resposta se restringe a Sim e Não, de modo que a resposta positiva implica em um processo adequado de segurança e a negativa em processo inadequado, torna-se importante analisar a somatória de respostas positivas dadas pelas instituições. $\mathrm{O}$ questionário aplicado apresenta questões que perpassam um processo ideal de proteção, pois engloba a segurança física, eletrônica, rotinas e plano de segurança, conhecimento e controle do acervo e formação do responsável pela coleção. Não existe uma estimativa de quais são as condições de segurança mínima que uma instituição deve ter, mas, com certeza, quanto menor a quantidade de respostas positivas às questões aqui analisadas, maior será a vulnerabilidade da instituição ao roubo e furto de livros raros. 
São analisadas as variáveis independentes presentes em 35 (37,5\%) das 80 questões aplicadas; ou seja, são analisadas questões como a de número 28, por exemplo, que pergunta sobre a existência ou não de câmeras no Setor de obras raras. A resposta a essa questão não depende da resposta de outra questão, diferente, por exemplo, da 29, que pergunta se nas instituições que possuem câmeras, estas têm visão noturna. De modo que a resposta à questão 29 está condicionada à resposta da questão 28 e por isso não estará na análise que se propõe esse subitem.

As questões analisadas são:

13 - Há funcionários exclusivos para o Setor?

16 - O acesso ao acervo de obras raras é restrito?

17 - A Coleção de obras raras está separada do restante do acervo?

18 - Existe algum reforço extra nas paredes que circundam a coleção?

19 - Existe cofre para abrigar a coleção ou parte dela?

21 - Os funcionários do Setor têm visão total do salão de leitura?

22 - As portas que dão acesso ao Setor são consideradas resistentes?

24 - As janelas que dão acesso ao Setor são consideradas resistentes?

28 - O Setor possui monitoração por câmeras?

31 - No Setor existem detectores de movimento?

32 - No Setor existem alarmes que indiquem invasão ou arrombamento?

33 - Nas portas do Setor existem trancas eletrônicas?

37 - Existe uma política de controle de chaves?

38 - Existe uma política de reposição e duplicação de chaves?

39 - A emissão de chaves e cartões magnéticos de identificação é controlada? 
40 - A perda de chaves é registrada?

41 - A instituição possui equipe de segurança?

46 - Todos os livros da Coleção estão catalogados?

48 - Já foi feito inventário da Coleção?

51 - São realizadas consultas em bibliografias especializadas?

52 - É feita análise bibliológica?

53 - Existe controle de usuário do acervo?

55 - É feita a digitalização do acervo?

56 - É feita a microfilmagem do acervo?

57 - Existe registro de quais livros possuem gravuras originais?

58 - Após a consulta, é feita verificação de integridade dos títulos consultados?

60 - O acervo está segurado?

61 - Existem normas para acesso em horários especiais, tais como a noite, finais de semana e feriados, diferenciados do horário normal de atendimento ao público?

62 - Usa-se marca de propriedade nos exemplares?

64 - Existe plano de emergência caso ocorra roubo ou furto no Setor?

66 - Já foi feito Gerenciamento de Risco para o Setor?

68 - Existe controle formal para a transferência de obras raras para restauração?

73 - Existe uma política de segurança formalizada para o Setor?

77 - O responsável pela Coleção já fez curso sobre segurança contra roubo de acervos?

78 - O responsável pela Coleção permanece no Setor durante todo o seu horário de funcionamento? 
Portanto, a presente análise visa a verificar a utilização das medidas de segurança em conjunto, pois, individualmente, podem haver itens considerados de menor eficácia contra roubo e furto, mas que somados a outras ferramentas podem fortalecer o esquema de segurança das instituições.

Infelizmente o número de instituições que deixaram de responder ao menos uma das 35 questões analisadas é muito grande, totalizando 33 (40,24\%); ou seja, apenas 49 (59,65\%) instituições, de 82, responderam a todas as 35 questões analisadas. Destas 49 instituições, 30 (61,22\%) assinalaram positivamente menos da metade das questões. Apenas 7 (14,28\%) respondentes marcaram positivamente mais de 2/3 das questões; ou seja, acima de 23 questões. A média é de 16,9 respostas positivas por instituição, abaixo de 17,5, que é a metade das 35 questões analisadas. Estes dados demonstram, sem possibilidade de generalização, que as instituições respondentes não usam metade dos recursos de segurança perguntados e por isso se expõem ao risco de roubo ou furto em seu acervo. Dessa forma é possível ver que as instituições guardiãs de livros raros pesquisadas não estão seguras contra roubo e furto.

\subsection{Segunda etapa - Casos de roubo e furto de livros raros}

Nesta etapa são analisados os dados referentes aos roubos e furtos de livros raros. Foram identificados, dentro do possível, a quantidade de livros roubados ou furtados, os dados sobre recuperação de obras, o modo como foram descobertos os roubos e furtos, a iniciação de inquérito policial e o julgamento de criminosos. Para levantar estes dados foram aplicados questionários junto às instituições onde ocorreram roubos e furtos, além do contato com a Polícia Federal, o Ministério Público Federal e acesso a alguns processos judiciais.

Os casos analisados são os do Instituto de Pesquisas Jardim Botânico do Rio de Janeiro; Palácio do Itamaraty do Rio de Janeiro; Museu Histórico Nacional (MHN) do Rio de Janeiro; Museu Nacional da Universidade Federal do Rio de Janeiro (UFRJ); Biblioteca da Escola de Belas Artes (EBA) da UFRJ; Arquivo Geral da Cidade do Rio de Janeiro (AGCRJ); Biblioteca Mário de Andrade de São Paulo; 
Biblioteca Pública do Paraná; Museu Raimundo Ottoni de Castro Maya - ou, como também é conhecido, Museu Chácara do Céu, do Rio de Janeiro; Fundação Oswaldo Cruz (FIOCRUZ) do Rio de Janeiro; Instituto Geográfico e Histórico da Bahia (IGHB); Museu Paraense Emílio Goeldi; Instituto de Botânica de São Paulo; e Centro de Ciências, Letras e Artes (CCLA) de Campinas.

Entre as instituições respondentes ao questionário sobre os casos de roubo ou furto estão: Museu Raimundo Ottoni de Castro Maya, Museu Paraense Emílio Goeldi, Museu Nacional da UFRJ, Instituto de Pesquisas Jardim Botânico do Rio de Janeiro e Fundação Oswaldo Cruz. Sobre o caso ocorrido no Instituto de Botânica de São Paulo, quem respondeu foi a $3^{\text {a }}$ Delegacia do Patrimônio do Departamento Estadual de Investigações Criminais da Polícia Civil do Estado de São Paulo.

Na pergunta de número 75 do questionário sobre prevenção situacional, foi inquirido se a instituição teria algum caso de desaparecimento de livros raros. Das 21 instituições que responderam positivamente à questão, em novo contato para envio de outro questionário que averiguaria sobre os detalhes do desaparecimento, 3 disseram que haviam se equivocado na resposta. Das 18 instituições restantes, 10 $(55,55 \%)$ responderam ao segundo questionário enviado. Os nomes destas instituições não são revelados, pois esta foi a condição para que elas respondessem aos dois questionários enviados.

\subsubsection{Instituto de Pesquisas Jardim Botânico do Rio de Janeiro}

O crime ocorreu nesta instituição, provavelmente em novembro de 2003. Segundo a própria instituição, foi feito um inventário, iniciado em março de 2004, que constatou o desaparecimento de livros raros. Enquanto apuravam melhor o fato, saíram notícias em maio de 2004 sobre a prisão de um criminoso envolvido em crimes semelhantes, que prontamente foi reconhecido como usuário frequente do Instituto.

Em 01 de junho de 2004 foi instaurado o inquérito IPL 112/2004 para averiguação dos fatos. $\mathrm{O}$ Instituto informou que os dois suspeitos assinaram o livro 
de presenças usando nomes falsos. Foi gerado processo judicial relacionado ao crime, na 2 ${ }^{\mathrm{a}}$ Vara Federal Criminal do Rio de Janeiro, de número 051764133.2004.4.02.5101. Na sentença proferida neste processo, o laudo grafotécnico comprovou que as assinaturas falsas saíram das mãos dos réus.

Na Denúncia do Ministério Público Federal, em 12 de maio de 2008, é alegado que os réus tentavam criar um clima de proximidade entre eles e os funcionários da instituição, com o intuito de iludir a vigilância sobre eles, o que facilitou a subtração das obras.

Os livros furtados, segundo informações passadas pela instituição, foram os volumes 1 e 2 da obra: MARTIUS, Karl Friedrich Philips von. Nova genera et especies plantarum quas itinere per Brasiliam. Monachii [Munique, Alemanha]: Typis Caroli Wolf, 1824-. Os três volumes da obra: SPIX, Johann Basptist Von. Amphibia... Monachii [Munique, Alemanha]: Impensis Editoris, 1839. 3 v. Nesta obra, os volumes 1 e 2 estavam encadernados juntos, e as partes 1 e 2 do volume 3 estavam encadernadas juntas em outro volume; ou seja, os três volumes estavam encadernados formando 2 volumes. A outra obra levada foi: ALDINO, Tobia. Exactissima descriptio rariorum qvarvndam plantarvm... Romae: Typis lacobi Mascardi, 1625.

Dos cinco exemplares levados, foram recuperados quatro, conforme relatou o Instituto. As obras foram devolvidas anonimamente pelos correios ao Museu Nacional, que, ao verificar que as obras não the pertenciam, entrou em contato com o Jardim Botânico. As obras apresentavam sinais de restauração recente e as marcas de propriedade haviam sido retiradas por processos químicos.

Os dois suspeitos foram condenados, em 19 de novembro de 2008, a 5 anos de reclusão e pagamento de 60 dias-multas. Entraram com pedido de redução de pena que foi negado no Acórdão ${ }^{34}$ proferido em 09 de fevereiro de 2010, na Apelação Criminal no ACR/6763, julgada pelo Tribunal Reginal Federal da $2^{\underline{a}}$ Região

${ }^{34}$ É a decisão judicial proferida em segundo grau de jurisdição por uma câmara/turma de um Tribunal. Os julgados recebem este nome por serem proferidos de forma colegiada e refletirem 0 acordo de mais de um julgador. Este acórdão pode ser unânime ou não unânime. (DIREITONET, 2014, online) 
(TRF2). O relator do recurso sugeriu a diminuição da pena, mas foi voto vencido. Devido à decisão de manutenção da pena, os réus entraram com embargos infringentes ${ }^{35} \mathrm{n}^{\text {0 }}$ ENUL/6612, que também foram negados em 03 de dezembro de 2010; ou seja, a pena aplicada foi a determinada no processo de origem.

\subsubsection{Palácio do Itamaraty do Rio de Janeiro}

Segundo denúncia do Ministério Publico Federal, em 07 de julho de 2008, que consta no processo 0513911-48.2003.4.02.5101 presente na $6^{\text {a }}$ Vara Federal Criminal, o furto foi descoberto em 21 de julho de 2003. No entanto, a suspeita sobre quem havia cometido o crime só se deu por meio de reportagem sobre a prisão de um dos criminosos, que havia cometido furto semelhante, sendo identificado pelos funcionários como frequentador do Palácio do Itamaraty. Foram indiciados dois suspeitos, sendo um deles condenado também no crime do Instituto de Pesquisas Jardim Botânico do Rio de Janeiro.

Segundo testemunho da Diplomata Chefe do Setor de Documentação do Itamaraty, em 22 de fevereiro de 2010, presente no processo judicial citado acima, ela foi avisada por uma funcionária, em junho de 2003, que não estavam sendo localizados um álbum de fotografias e um mapa do acervo da mapoteca. Este evento, em um primeiro momento, não foi tratado como subtração porque os funcionários acharam que estavam apenas tendo dificuldades de encontrar as obras. Mas, em 21 de julho de 2003, foi detectada a ausência de muitas obras do acervo, fato que foi prontamente comunicado às chefias da instituição e à Polícia Federal, além de ter sido feito inventário para averiguar quais as obras desaparecidas.

$\mathrm{Na}$ Denúncia do MPF, consta notícia sobre a subtração de cerca de 60 documentos raros cartográficos (pranchas, mapas e folhas de atlas) e 2.350

\footnotetext{
${ }^{35}$ Cabem embargos infringentes quando o acórdão não unânime houver reformado, em grau de apelação, a sentença de mérito, ou houver julgado procedente ação rescisória. Se o desacordo for parcial, os embargos serão restritos à matéria objeto da divergência. (LEI № 5.869, 1973, online)
} 
materiais iconográficos (litografias, fotografias, gravuras, fototipias e estampas) ${ }^{36}$. Entre as obras furtadas estão 12 pranchas do atlas Estado do Brasil coligido das, mais: sertas notícias que pode aiuntar..., obra de João Teixeira Albbernas, publicado em 1631, e 11 folhas, sendo duas alegorias e 9 mapas, do Atlas de Van Keulen. Algumas obras foram devolvidas por correio em 25 de julho e 25 de agosto de 2003. Assim como, 7 mapas, dos 9 levados e as 2 alegorias do Atlas Van Keulen foram recuperadas em apreensão feita pela Polícia Civil de São Paulo.

$\mathrm{Na}$ sentença, proferida em 20 de abril de 2010, é dito que houve suspeitas do envolvimento de funcionários. No entanto, isso não foi comprovado. Diz também que não é possível imputar aos réus o furto de todas as obras, pois outra hipótese é a de que pode ter havido vários furtos ao longo dos anos. Portanto, os réus só foram julgados pelo furto dos 9 mapas e 2 alegorias do Atlas de Van Keulen, pois 7 dos 9 mapas furtados e as 2 alegorias estavam em posse dos suspeitos. $O$ juiz ainda relata que a motivação para os crimes foi a ganância e a busca por riqueza fácil e que os crimes demonstraram frieza e premeditação. Os suspeitos foram condenados a 5 anos de reclusão e 185 dias-multas (unitário = 1 salário mínimo), em regime fechado. O juiz justificou a sentença acima da pena mínima pelo fato das consequências do crime serem gravíssimas, por se tratar de uma obra da qual só existem 6 exemplares, fazendo assim parte do patrimônio histórico e cultural brasileiro, cuja gravidade é superior às subtrações corriqueiras de propriedades privadas. Foram negados os recursos dos réus sobre a pena aplicada.

\subsubsection{Museu Histórico Nacional do Rio de Janeiro}

Segundo depoimento de abertura de boletim policial na $1^{\underline{a}}$ Delegacia Seccional de Polícia, da Polícia Civil do Estado de São Paulo, feito no dia 24 de junho de 2004, presente no processo de número 0523293-31.2004.4.02.5101 localizado na $1^{\underline{a}}$ Vara Federal Criminal do Rio de Janeiro, os suspeitos estiveram no

36 A lista de obras furtadas e devolvidas, retirada do Processo Criminal № 051391148.2003.4.02.5101, na 6 ${ }^{a}$ Vara Federal Criminal do Rio de Janeiro, consta no Volume 2 no Apêndice $\mathrm{K}$. 
Museu em maio e junho de 2002 e em abril e maio de 2004. O crime foi descoberto por acaso durante um curso realizado no Arquivo do Estado de São Paulo, onde uma arquivista do museu reconheceu obras pertencentes à instituição. As obras estavam de posse do Arquivo do Estado de São Paulo, pois o mesmo era o fiel depositário de várias outras obras que haviam sido apreendidas durante a prisão de criminosos ligados a roubo e furto de acervos de memória.

Segundo denúncia do Ministério Público Federal, em 22 de novembro de 2005, os dois suspeitos são os mesmos do crime ocorrido no Palácio do Itamaraty do Rio de Janeiro, e um deles também foi condenado pelo crime do Instituto de Pesquisas Jardim Botânico do Rio de Janeiro. Segundo o depoimento já mencionado, o suspeito disse ser aluno de Biblioteconomia e restaurador de obras raras, inclusive se voluntariando para ser estagiário da instituição. Este suspeito sempre comparecia ao Museu para consultar as obras usando um casaco muito grande, mesmo estando calor, motivo pelo qual, na segunda visita dos suspeitos, a arquivista acionou um segurança para acompanhar a consulta, fato que levou a uma discussão entre a arquivista e um dos suspeitos.

As obras levadas e recuperadas, conforme Declaração de Retirada das obras que estavam no Arquivo do Estado de São Paulo, são o álbum Scenas da Vida Carioca, de Raul, de 1924, e as Revistas Manchete de 20 de agosto de 1960, 11 de outubro de 1952, 26 de outubro de 1952 e a de número 326. Portanto, todas as obras furtadas foram recuperadas; dentre elas há apenas um livro. Segundo depoimento em 14 de julho de 2004, da mesma arquivista que encontrou as obras, algumas haviam sido danificadas na tentativa de suprimir as marcas de propriedade, arrancando as folhas de rosto e raspando alguns carimbos secos.

O processo judicial ainda não foi finalizado e por isso não há notícias sobre condenação ou absolvição dos réus. Foi enviado questionário à instituição inquerindo sobre o furto e a mesma, por e-mail, disse que não seria possível respondê-lo. 


\subsubsection{Museu Nacional da Universidade Federal do Rio de Janeiro (UFRJ)}

Segundo a própria instituição, o furto foi descoberto no dia 20 de abril de 2004, quando um usuário pediu para consultar uma obra que não foi encontrada. Diante do ocorrido, foi determinada a execução de um inventário em toda a coleção que constatou a ausência de outros exemplares.

No boletim de ocorrência da 1a Seccional da Polícia Civil de São Paulo, de 07 de maio de 2004, dentro do processo de número 2004.51.01.537024-3, da $2^{\text {a }}$ Vara Federal Criminal, redistribuído para o processo 0514146-78.2004.4.02.5101, da 10 Vara Federal Criminal, um comerciante de antiguidades se apresentou voluntariamente a esta delegacia para devolver algumas obras que ele havia adquirido. Segundo o comerciante, uma pessoa havia the vendido o livro Historia Natualis Brasiliae e 75 fotografias por $\mathrm{R} \$ 2.000,00$. Ao ver notícia sobre o furto no Museu Nacional, o comprador entrou em contato com quem havia the vendido e inquerido sobre a procedência das obras. O vendedor pediu o material de volta, pois estava com medo, por ter assinado promissórias a este comerciante. Segundo o vendedor, ele havia adquirido o material de alguém em uma feira de antiguidades e não sabia sobre a procedência. O vendedor é um dos condenados no furto ocorrido no Instituto de Pesquisas Jardim Botânico do Rio de Janeiro e o outro condenado neste crime foi reconhecido, em fotografia, pelos funcionários do Museu Nacional, como o outro visitante que também esteve ali.

O Museu Nacional informou que no furto foram danificados 39 in-fólios (faltando páginas) e que 12 exemplares sumiram, sendo também danificadas 10

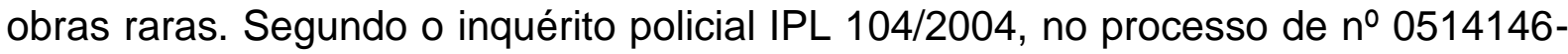
78.2004.4.02.5101, presente na 10 ${ }^{\underline{a}}$ Vara Federal Criminal do Rio de Janeiro, entre as obras levadas ou danificadas estão o Rerum per octennium in Brasília et alibi nuper gestarum..., obra de Gasparis Barlaei, publicado em 1647, levado por inteiro e 
- Collection d'oiseaux natifs de notre pais et etrangers..., obra de Louis Jean Mari Daubenton, de 1776, na qual estão faltando algumas estampas. ${ }^{37}$

Na Denúncia do MPF, de 17 de maio de 2010 , no processo que está na $10^{\text {a }}$ Vara Federal Criminal, do Rio de Janeiro, de oㅡ 0514146-78.2004.4.02.5101, foram indiciados criminalmente 6 suspeitos. Dois deles foram condenados pelo furto no Palácio do Itamaraty e respondem a processo pelo furto no Museu Histórico Nacional, havendo também participação do irmão de um deles. Outro indiciado também foi condenado pelo crime ocorrido no Instituto de Pesquisas Jardim Botânico do Rio de Janeiro, e sua irmã também foi indiciada. O sexto indiciado é um comerciante que adquiriu obras dos demais e que, segundo denúncia, sabia da procedência criminosa dos exemplares.

Os acusados geraram uma rotina de visitação ao Museu Nacional entre novembro de 2003 e janeiro de 2004, conforme mostra a denúncia. Os mesmos criavam uma relação de confiança com os funcionários da biblioteca para diminuição da vigilância sobre eles.

Uma das obras desta instituição citada na Denúncia do MPF, como objeto de furto dos acusados, é o livro America Tertia Pars, de 1592, do autor Hans Staden. Esta obra foi vendida a um comerciante, que também faz parte desse processo criminal, pois, segundo a denúncia, ele tinha conhecimento da procedência da mesma no momento da compra. O comerciante denunciado diz que adquiriu, em março de 2004, 8 obras por $\mathrm{R} \$ 3.000,00$, mais mercadorias. Dez dias após essa compra, realizou uma segunda, no valor de $\mathrm{R} \$ 25.000,00$, adquirindo a coleção Flora Brasiliae Meridionalis e Florae Fuminensis, que posteriormente seria identificada como pertencentes ao Centro de Ciências, Letras e Artes de Campinas, no estado de São Paulo. Uma terceira compra foi feita 15 dias após a segunda, no valor de $\mathrm{R} \$ 7.000,00$, na qual se encontra a obra já mencionada, America Tertia Pars.

37 A lista de obras furtadas e devolvidas, retirada do Processo Criminal $\mathrm{n}$ ํ 051414678.2004.4.02.5101, na 10 ${ }^{\mathrm{a}}$ Vara Federal Criminal do Rio de Janeiro, consta no Volume 2 no Apêndice L. 
Há, no processo judicial, notícias de várias devoluções, de estampas e folhas com textos, dos materiais que haviam sido furtados. As obras foram devolvidas pelos correios ao longo do mês de maio de 2004. Entre as obras recuperadas estão 59 pranchas devolvidas por dois leiloeiros. Em depoimento, os leiloeiros disseram que o rapaz que thes vendeu as pranchas se apresentou como comerciante de livros antigos e deu demonstrações de conhecer muitas pessoas no ramo do comércio de antiguidades.

Segundo relato da instituição, dos 12 in-fólios sumidos foram recuperados 9 . Os demais materiais não foram recuperados. O processo segue em andamento e por isso não há notícia de condenação ou absolvição dos suspeitos.

\subsubsection{Biblioteca da Escola de Belas Artes (EBA) da Universidade Federal do Rio de Janeiro (UFRJ)}

No Termo de Declarações, de 06 de março de 2006, presente no Inquérito Policial IPL 06/2006, dentro do processo de número 0509504-91.2006.4.02.5101, na $10^{\underline{a}}$ Vara Federal Criminal do Rio de Janeiro, há notícia do furto da Escola de Belas Artes da UFRJ, onde foi subtraído o livro Histoire des oiseaux du Brésil, do autor Jean Théodore Descourtilz, de 1852. Neste documento a bibliotecária da instituição declara que em 22 de fevereiro de 2006 a obra foi furtada por duas mulheres, que fizeram ao todo três visitas à biblioteca. $\mathrm{O}$ dia 22 de fevereiro foi a última data em que as mulheres foram à EBA, quando, por volta das $15 \mathrm{~h} 30$, desconfiando da demora das usuárias que haviam ido ao banheiro, a bibliotecária resolveu verificar a mesa onde faziam as consultas e percebeu que o livro mencionado havia sido subtraído.

A bibliotecária, em sua declaração, disse que na segunda visita das moças havia um rapaz as acompanhando, que posteriormente seria reconhecido por foto como sendo um dos acusados de participar dos crimes no Instituto de Botânica do Rio de Janeiro, do Palácio do Itamaraty, do Museu Histórico Nacional e do Museu Nacional do Rio de Janeiro. Segundo a declarante, a obra havia sido substituída por uma similar. Apesar da citação do acompanhamento às moças de um rapaz, a 
denúncia do MPF, de 28 de novembro de 2012, presente no processo já citado da $10^{\text {a }}$ Vara Federal Criminal, contempla apenas as duas moças, provavelmente devido ao fato do rapaz não ter participado do ato criminoso em si, não estando no último dia de visitação, que foi quando a obra foi furtada. Uma destas moças seria presa em flagrante em 2007, junto ao rapaz mencionado no processo e a outros rapazes também indiciados por furtos de livros de algumas das instituições aqui mencionadas.

Em contato telefônico com a EBA, foi informado por uma funcionária que a obra foi recuperada em São Paulo. As denunciadas ainda não foram condenadas ou absolvidas no processo judicial, que continua aberto.

\subsubsection{Arquivo Geral da Cidade do Rio de Janeiro (AGCRJ)}

Segundo Cozer (2014), o furto ocorreu em junho de 2006 e foi descoberto por um funcionário que notou a ausência de uma fotografia do acervo, o que gerou o início de um inventário em toda a coleção do arquivo. A autora diz que foram levados mais de 3.000 itens do acervo, entre fotografias, periódicos e gravuras.

Dentro da listagem de materiais levados estão periódicos, fotos, gravuras, entre outros matérias ${ }^{38}$. Portanto, dentre estes só há dois que podem ser considerados livro, ou parte de um. Como é o caso das gravuras do Debret, que pelas informações apresentadas pela instituição, fariam parte do título DEBRET, Jean Baptiste. Viagem pitoresca e historica ao brasil. Paris: R De C Maya, 1954. 1 v., conforme registro similar na Biblioteca Central da Universidade de Brasília. Assim, como acontece com o título Scenas da vida carioca, que, na listagem de obras desaparecidas disponibilizada no site do AGCRJ, foi considerada como periódico, mas que, na verdade, trata-se da reunião, em livro, de várias caricaturas de Raul Pederneiras, que foram publicadas em vários periódicos. Esta obra também foi furtada no Museu Histórico Nacional, que, em contato telefônico, informou se

\footnotetext{
${ }^{38} \mathrm{~A}$ lista de obras furtadas, retirada do site do AGCRJ, consta no Volume 2 no Apêndice M.
} 
tratar de um livro. Sendo também tido como livro na Biblioteca Central da Universidade de Brasília.

Cozer (2014) dá notícia da recuperação das gravuras em 2007 e do recebimento de obras pelo correio em 2013. No entanto, a quantidade e os títulos das obras enviadas não foram divulgados. A autora ainda relaciona este caso com a quadrilha que agiu em outros crimes semelhantes, como nos furtos já mencionados do Instituto de Pesquisas Jardim Botânico do Rio de Janeiro, no Palácio do Itamaraty, no Museu Histórico Nacional, no Museu Nacional da UFRJ e na Escola de Belas Artes da UFRJ. Foi feito contato telefônico e enviado questionário sobre o crime, mas não houve resposta desta instituição. Não se teve acesso a qualquer processo que citasse o furto do AGCRJ. Portanto, não se tem notícias sobre condenação ou absolvição de suspeitos para este crime em específico.

\subsubsection{Biblioteca Mário de Andrade de São Paulo}

Nesta instituição houve o furto de três periódicos em 2003 e 2004 . Apesar de não ser foco desta pesquisa, pela natureza dos objetos furtados, serão apresentados de forma sucinta alguns dados sobre o caso, pois a mesma instituição viria a ter um evento de furto de livros raros em 2006.

Os periódicos foram encontrados na posse de três suspeitos, que são os mesmos já mencionados em outros casos nesta pesquisa, e que fazem parte de uma quadrilha que cometeu crimes em outras instituições, como o Instituto de Pesquisas Jardim Botânico do Rio de Janeiro e o Palácio do Itamaraty, entre outras. O possível mentor da quadrilha era, inclusive, estagiário da Biblioteca Mário de Andrade na época deste crime. Estas informações estão presentes na sentença do processo no 050.04.038423-3, da 30ª Vara Criminal do Foro Central da Capital (São Paulo), proferida no dia 04 de novembro de 2005. Nesta sentença é possível ver que os 3 acusados foram condenados a 3 anos de prisão com regime inicial aberto, podendo a pena ser substituída por prestação de serviços à comunidade e pagamento de 10 dias-multa. Posteriormente, em apelação de nํ 993.06.065158-7, proferida em 21 de agosto de 2008, os acusados seriam absolvidos do furto. 0 
acesso à sentença e à apelação só foi possível por estarem dentro do processo no 0509504-91.2006.4.02.5101 da 10 ${ }^{\text {a }}$ Vara Federal Criminal do Rio de Janeiro.

O segundo furto, que é objeto de estudo deste trabalho, foi descoberto em 06 de julho de 2006. Carvalho e Gallo (2006) dizem que o crime foi descoberto na solicitação de empréstimo de material da Coleção de obras raras, sendo constatada a ausência de 3 das 11 gravuras do livro que havia sido solicitado. Conforme matéria publicada no site da Prefeitura de São Paulo, em 09 de junho de 2006, foram levadas 107 gravuras de artistas como Rugendas, Debret, Steinmann e Burmeister. ${ }^{39}$

Segundo auto de fiel depositário, de 23 de novembro de 2007, presente no processo no 0812174-92.2007.4.02.5101 da $4^{\mathrm{a}}$ VFC, retirados do apenso 1 do processo no 0800583-02.2008.4.02.5101, foram entregues à Biblioteca Mario de Andrade 22 gravuras de Debret e Rugendas.

Brandalise (2011) dá notícia da recuperação de mais uma gravura, do Atlas zur Reise in Brasilien, de autoria de Johann Baptist von Spix e Carl Friedrich Martius, de 1823. Não há mais notícias de obras levadas e recuperadas neste caso específico. Foi feito contato telefônico e enviado questionário ao Diretor da Biblioteca, ao Bibliotecário responsável pela Coleção de obras raras e à Secretaria de Segurança Pública de São Paulo. Não houve retorno. Portanto, não foi possível identificar processo judicial relacionado ao caso e, consequentemente, se houve alguém condenado ou absolvido.

\subsubsection{Biblioteca Pública do Paraná}

No Termo de Declaração da bibliotecária da Sessão de obras raras da instituição na época, realizado no dia 16 de outubro de 2006, presente no processo no 2007.0003086-7 da 11aㅡ Vara Criminal do Foro Central de Curitiba no Paraná, há

\footnotetext{
${ }^{39}$ A lista de obras furtadas e recuperadas, retirada do site da Prefeitura de São Paulo e do auto de fiel depositário, de 23 nov. 2007, presente no processo no 0812174-92.2007.4.02.5101 da 4a VFC, retirados do apenso 1 do processo no $0800583-02.2008 .4 .02 .5101$, consta no Volume 2 no Apêndice N.
} 
notícia de que uma servidora inqueriu a declarante sobre se a mesma havia retirado algum material da Seção de obras raras. Como a resposta foi negativa, as duas funcionárias, acompanhadas de uma terceira, verificaram se as obras não estavam acomodadas em outro local que não o de costume. Ao confirmarem o desparecimento dos exemplares levaram o caso à direção da biblioteca. Os funcionários se lembraram de um pesquisador que sempre fazia suas visitas trajado com uma capa de chuva grande e que o mesmo também havia feito pesquisas na Divisão de Periódicos daquela biblioteca.

O Termo de Depoimento da bibliotecária chefe da Divisão de Periódicos, também realizado em 16 de outubro de 2006, mostra que neste local a descoberta do furto ocorreu devido ao não atendimento de uma consulta solicitada por um usuário, pois o mesmo solicitou um periódico que não foi encontrado na estante, momento este em que os funcionários perceberam o sumiço de mais obras. Em conversa com as bibliotecárias da Sessão de obras raras, verificou-se que também lá haviam obras desaparecidas. Segundo Termo de Depoimento de uma estagiária da Sessão de obras raras, o suspeito sempre ia acompanhado de outro rapaz e em determinados momentos passou também a ir acompanhado de uma moça. $O$ suspeito disse cursar Biblioteconomia e perguntou sobre as condições para se estagiar naquela biblioteca. Estas informações batem com o modo de agir deste suspeito em outro furto, realizado no Museu Histórico Nacional.

No Auto de Avaliação solicitado pelo Centro de Operações Policiais Especiais do Departamento da Polícia Civil do Estado do Paraná, os peritos determinaram, por meio da avaliação de cotações em livrarias, sebos, antiquários e leilões, que as obras furtadas valiam em torno de $\mathrm{R} \$ 125.715,81$. Segundo Denúncia do Ministério Público do Estado do Paraná, entre as obras levadas, estão os títulos: Americanas, de 1875; Chrysalidas, de 1864; Histórias sem data, de 1909; Memorial de Ayres, de 1923; Papéis avulsos, de 1882; Relíquias de casa velha, de 1906; todos do autor brasileiro Machado de Assis. ${ }^{40}$

40 A lista de obras furtadas e localizadas na própria instituição, presente no processo no 2007.0003086-7 da 11 a Vara Criminal do Foro Central de Curitiba no Paraná, consta no Volume 2 no Apêndice $\mathrm{O}$. 
Na lista de obras localizadas na própria instituição, constam dois títulos que não estão na denúncia do MP/PR; são eles:

1 ALMEIDA, Guilherme de. Você (Cancioneiro). São Paulo: Nacional, 1931.

2 VERÍSSIMO, Érico. Incidente em Antares. Porto Alegre: Globo, 1977.

As Alegações Finais do Ministério Público do Paraná, redigidas em 05 de novembro de 2009, dizem que, apesar do reconhecimento do réu (o caso foi desmembrado) pelas funcionárias da Biblioteca Pública do Paraná, a instituição, em nova diligência, encontrou alguns dos materiais dentro da própria biblioteca. Por isso a Promotora de Justiça diz que não há como auferir, de maneira certa e absoluta, a autoria do crime pelo réu. Portanto, pelo princípio in dubio pro reo e de presunção da inocência ela promoveu pela improcedência da denúncia e absolvição do acusado.

Em sentença proferida no dia 24 de março de 2010, o Juiz diz que as testemunhas reconheceram, por fotos, sem sombra de dúvidas, os acusados; que a declaração do réu em não conhecer o outro acusado se demonstrou improcedente pelas declarações das testemunhas, que alegavam que os dois faziam as consultas na biblioteca juntos. Para o Juiz, o réu não apresentou qualquer prova a seu favor que desmerecesse as palavras das testemunhas e que a justificativa do acusado em dizer que visitou a biblioteca para uma pesquisa sobre Carmen Miranda não merece consideração, pois nenhum trabalho científico foi apresentado como comprobatório do fato. Segundo o juiz, estando comprovada a materialidade e a autoria, consubstanciada no depoimento das testemunhas, a prova é suficiente para a condenação, em conclusão contrária ao parecer do MPF.

O juiz considera ainda que houve qualificadora do concurso de pessoas, por ter sido mais de um agente a cometer o crime e que também está comprovada fraude, pois o réu conseguiu subtrair as obras ganhando a confiança das funcionárias dizendo ser pesquisador. Para isso ele frequentou durante alguns meses a Biblioteca Pública do Paraná com o intuito de angariar tal confiança, de modo que fosse iludida a atenção dos responsáveis pela vigilância das obras. 
$\mathrm{Na}$ condenação do réu, o juiz diz que não tem elementos suficientes nos autos para aferir os antecedentes criminais do acusado e que os motivos para o crime foram a busca do lucro fácil em detrimento do patrimônio público, normal para o fato em análise. Para o juiz, as consequências do delito foram elevadas, por ter prejudicado o patrimônio cultural e, com isso, a história da nação. A pena foi estabelecida em 4 anos de reclusão e 120 dias-multa, cada um no valor equivalente a um trigésimo do salário mínimo em vigor ao tempo dos fatos. De acordo com o juiz, por ser mais eficaz do ponto de vista pedagógico, ele substitui a pena privativa de liberdade por restritiva de direito, constante em prestação de serviços à comunidade, com as seguintes condições:

1 Não mudar de residência e não se ausentar da cidade onde reside por mais de 07 dias sem prévia autorização judicial;

2 Recolher-se diariamente em sua residência, no período noturno e nos dias de folga, das 22:00 às 05:00 horas;

3 Comparecer em Juízo, bimensalmente, para informar e justificar sua atividade, bem como manter atualizado seu endereço;

4 Prestar serviços à comunidade, nos termos do artigo 46, §3ํ do Código Penal, ou seja, atribuídas em conformidade com sua aptidão, devendo ser cumpridas à razão de uma hora de tarefa por dia de condenação, de modo a não prejudicar sua jornada normal de trabalho.

Após recurso interposto, em 20 de dezembro de 2010, houve manutenção da pena, como é possível ver na Guia de Recolhimento Provisória assinada em 29 de abril de 2011 pelo Juiz que expediu a sentença.

\subsubsection{Museu Raimundo Ottoni de Castro Maya ou Museu Chácara do Céu do Rio de Janeiro}

Em relato da própria instituição é dito que o roubo ocorreu em 24 de fevereiro de 2006, véspera de carnaval, quando as ruas próximas ao Museu ficaram 
interditadas. Por este motivo os funcionários foram liberados às 15 horas. Contudo, quatro assaltantes rederam à mão armada os seguranças e alguns visitantes às 16 horas.

Os criminosos levaram o quadro La Danse, de Pablo Picasso, de 1956; a pintura Marine, de Claude Monet, datada aproximadamente do período entre 18801890; o quadro Le Jardim du Luxemburg, de Henri Matisse, de 1905; a obra de óleo sobre madeira chamada Homme d'une complexion malsaine écoutant le bruit de la mer ou Les deux balcons, do pintor Salvador Dali, de 1929; a faca de mesa, a faca de peixe e a colher de sopa, todas de prata, pertencentes a um faqueiro com 205 peças, feito na cidade de Porto em Portugal, entre 1870 e 1930, e o álbum: PICASSO, Pablo. Toros. 15 lavis inédits, poème de Pablo Neruda, traduit par Jean Marcenac. Paris: Au Vent d'Arles 1960. Pranchas soltas.

Das quinze pranchas deste livro, que contém poemas de Pablo Neruda ilustrados por Picasso, foram levadas 12, pois as outras 3 estavam acondicionadas em mapotecas em outro setor.

Segundo relato da instituição, nenhuma obra foi recuperada. Também não houve indiciados e por isso não houve processo judicial e, consequentemente, não houve condenados ou absolvidos pelo crime.

\subsubsection{Fundação Oswaldo Cruz do Rio de Janeiro (Fiocruz)}

Em relato da própria instituição é possível ver que o crime foi descoberto com a apreensão de parte das obras pertencentes à Biblioteca da Fiocruz, pela Polícia Federal, na Aduana de Iguazú-Argentina, fronteira entre a Argentina e o Brasil, em Foz do Iguaçu. A instituição acredita que os furtos ocorreram durante todo $o$ ano de 2007. Com a descoberta, a partir de contato do Iphan, foi feito inventário que constatou a subtração de mais obras.

A Procuradoria Federal junto à Fiocruz respondeu que foram levadas aproximadamente 250 obras e que foram recuperadas apenas 137 . Segundo a instituição, as obras foram recuperadas no Rio de Janeiro pela Delemaph (Delegacia 
Federal do Meio Ambiente e Patrimônio Histórico Nacional) da Polícia Federal, na apreensão no 418/2010 em agosto de 2010, quando foram recuperadas 51 litogravuras. O segundo lote de obras recuperadas ocorreu por meio do processo de repatriação pela Procuradoria Federal da Fiocruz em conjunto com o DRCl e a Polícia Federal de Foz do Iguaçú. A instituição recebeu as obras em 15 de novembro de 2011, sendo recuperados 12 livros e 49 lâminas. Já o terceiro lote de obras foi recuperado pela Fiocruz em 10 de julho de 2012, por meio de uma apreensão feita pela 14ํㅡㄹ Delegacia de Polícia de São Paulo, Capital. Foram recuperados neste momento 18 livros $^{41}$.

Após a apreensão das obras na Aduana Iguazú na Argentina, elas permaneceram em um galpão neste mesmo local. A quadrilha, que também participou da maioria dos outros crimes aqui estudados, tentou recuperar, à mão armada, as obras apreendidas, momento este em que foram presos em flagrante. A Fundação Oswaldo Cruz ainda informou que houve 4 criminosos presos e condenados na Argentina, a 5 anos e 4 meses de prisão em regime fechado e multa, por roubo qualificado, por uso de arma e formação de quadrilha, delitos tipificados nos arts. 166, inciso II, art. 167, inciso II, art. 12 e 29, inciso III do Código Penal Argentino. Na Argentina estes criminosos já foram soltos em condicional. No Rio de Janeiro também há o processo de número 200751018076778, localizado na 4ํㅡara Federal Criminal. Não foi possível ter acesso a este processo; não existem peças disponíveis online e não há indicação de quem são as partes envolvidas.

\subsubsection{Instituto Geográfico e Histórico da Bahia (IGHB)}

Na Denúncia do MPF, no processo de número 0812174-92.2007.4.02.5101

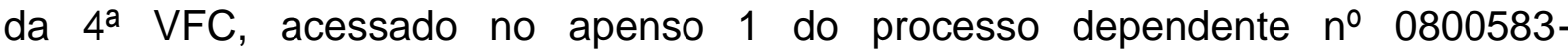
02.2008.4.02.5101, é possível ver que o crime ocorreu em setembro de 2007. Este documento descreve que uma moça que também teria agido em outros crimes, como o da Escola de Belas Artes da UFRJ, e outras duas pessoas não identificadas,

\footnotetext{
${ }^{41}$ A lista de obras furtadas e recuperadas, informada pela própria instituição, consta no Volume 2 no Apêndice P.
} 
fizeram-se passar por professores da cidade de Santos, apresentando-se à diretora do IGHB e dizendo ter amigos em comum em Santos, conseguindo assim a confiança da mesma. Os acusados usaram nomes falsos para acessar as obras.

No Auto de Fiel Depositário, de 06 de novembro de 2007, no processo oㅡ 0812174-92.2007.4.02.5101 da $4^{\text {a }}$ VFC, acessado no apenso 1 do processo dependente ํo 0800583-02.2008.4.02.5101, é possível ver que 12 obras foram devolvidas à Diretora do IGHB. ${ }^{42}$

Na declaração prestada pela Diretora do IGHB, em 06 de novembro de 2007, disponível no apenso 1 do processo já citado, é dito que o livro Rerum per octennium in Brasilia et álibi nuper gestarum sub praefectura..., de Barleus, não foi recuperado. Foi feito contato telefônico com a Diretora do IGHB, que confirmou que o referido livro continua desaparecido. A Diretora disse ainda que houve um segundo momento de recuperação de obras. Para averiguar estes detalhes e outros mais, foi enviado questionário a ela. No entanto, não houve resposta ao mesmo. $\mathrm{O}$ processo judicial continua em andamento e por isso não há notícia sobre condenação ou absolvição dos suspeitos.

\subsubsection{Museu Paraense Emílio Goeldi}

Em notícia vinculada no site do próprio Museu ${ }^{43}$, publicada por Leão (2014), o crime foi descoberto em 17 de dezembro de 2008, ao final do expediente, durante um treinamento para manuseio e curadoria das coleções.

Segundo relato da própria instituição, é certo afirmar que a ação criminosa não foi feita de uma só vez, sendo um trabalho que provavelmente foi realizado durante anos, por pessoas especialistas em livros raros e coleções especiais. Em matéria publicada no site do Museu, em 2008, é dada a notícia do desaparecimento

\footnotetext{
${ }^{42} \mathrm{~A}$ lista de obras furtadas e recuperadas, presente no processo no 0812174-92.2007.4.02.5101, da $4^{\text {a }}$ VFC, acessado no apenso 1 do processo dependente $n^{0}$ 0800583-02.2008.4.02.5101, consta no Volume 2 no Apêndice $P$.

${ }^{43}$ Site do Museu com a notícia: http://www.museugoeldi.br/sobre/NOTICIAS/2008/obras_furtadas d.html. Acesso em: 06 fev. 2012.
} 
de 40 títulos, distribuídos em 65 exemplares. Na notícia, o único título citado diretamente é o da obra Metamorphosis Insectorum Surinamensium, de Maria Sybilla Meriaen, publicada em 1730, em Amsterdã, na Holanda.

Depois de 10 de fevereiro de 2014, quando foi respondido o questionário enviado ao Museu Goeldi, houve recuperação de um exemplar desta instituição. Segundo Leão (2014), a obra Rerum Medicarum Novae Hispaniae, escrito em latim por Francisco Hernandez, em 1628, foi oferecida a um livreiro em Nova lorque, nos Estados Unidos, que desconfiou da venda e comunicou as autoridades brasileiras. A autora ainda comenta que a obra apresentava danos, como capa original cortada, manchas de umidade e carimbos cobrindo a marca d'água do Museu Paraense Emílio Goeldi.

Dos 60 exemplares, apenas um foi recuperado. A instituição disse que não poderia divulgar a lista das obras furtadas. Não há notícias de processos judiciais ligados ao caso, nem de suspeitos.

\subsubsection{Instituto de Botânica de São Paulo}

Em contato telefônico, a instituição disse que não poderia responder ao questionário enviado, pois ainda estavam fazendo averiguações internas. A $3^{\text {a }}$ Delegacia do Patrimônio do Departamento Estadual de Investigações Criminais (Deic), da Polícia Civil de São Paulo, que cuidou do caso, informou que no dia 02 de fevereiro de 2012, 3 homens usando arma de fogo renderam funcionários e seguranças para subtraírem as obras e dois revólveres dos vigilantes. Bedinelli (2012) diz que as obras levadas foram: Sertum palmarum brasiliensium, de 1903 (dois volumes); Flora Fluminensis, de 1827 (11 volumes); e Bambusees, de 1913 (dois volumes).

Segundo a $3^{\text {a }}$ Delegacia do Patrimônio, os criminosos chegaram solicitando pesquisa bibliográfica sobre como cuidar de orquídeas e que inesperadamente um dos suspeitos anunciou o assalto usando uma arma de fogo. Os indivíduos pediram 
para serem levados à sala de obras raras e em seguida prenderam os funcionários na sala da direção, amarrando as vítimas. Depois fugiram levando as obras.

Rodrigues (2012), da assessoria de comunicação do Departamento Estadual de Investigações Criminais (Deic) da Polícia Civil do Estado de São Paulo, dá notícia sobre a recuperação dos livros roubados, no dia 03 de abril de 2012. Segundo o autor, a prisão de um homem procurado durante a apuração da autoria do ataque fez com que, em sequência, a equipe policial descobrisse o local das publicações.

Em matéria feita por Cardoso (2012), o Diretor do Deic mostra que, devido à prisão do suspeito e o consequente não comparecimento ao local onde as obras seriam negociadas, os outros envolvidos provavelmente perceberam a movimentação das viaturas descaracterizadas próximo ao local onde ocorreria a venda e abandonaram as obras.

A 3믈 Delegacia do Patrimônio informou que os livros recuperados foram: 11 volumes de Flora Fluminensis, 5 volumes de título Sertum Palmarum Brasileinsium, 2 volumes de Le Bambusées, 1 volume de Graminearum Genera, 1 volume do Herbarium Amboinense, 1 volume do Plantarum Brasiliae e 1 volume do Flora Brasilica; ou seja, foram recuperadas mais obras do que o informado como desparecido na época em que ocorreu o roubo.

Ainda foi informado pela $3^{\text {a }}$ Delegacia que houve 3 suspeitos indiciados criminalmente, mas que eles ainda não foram condenados ou mesmo absolvidos judicialmente.

\subsubsection{Centro de Ciências, Letras e Artes de Campinas (CCLA)}

Na denúncia do MPF, de 17 de maio de 2010, no processo de número 0514146-78.2004.4.02.5101, localizado na 10ª Vara Federal Criminal, há notícia de que foram encontrados com um comerciante 12 livros da Coleção Flora Fluminenses, de Josepho Mariano a Conceptione Vellozo, e 3 livros da Coleção Florae Brasiliae Meridionalis, de Augusto de Saint-Hilaire, Adriano de Jussie e Jacobo Cambessedes, pertencentes ao CCLA. As obras foram apreendidas em 
diligência no dia 07 de junho de 2004, para averiguação do furto de livros raros do Museu Nacional da UFRJ. O processo é o mesmo que traz os 6 suspeitos de terem cometido o furto no Museu Nacional.

Conforme boletim de ocorrência presente no processo citado, feito em 26 de julho de 2004 pelo diretor do CCLA, a descoberta do crime se deu pelo contato da Polícia Federal dizendo ter recuperado as obras. A denúncia do MPF diz que as marcas de propriedade foram suprimidas por alteração física e até mesmo lavagem química do papel; mas que, devido à péssima qualidade da ação, foi possível estabelecer a proveniência das obras como sendo do CCLA. O processo judicial referente a este furto permanece aberto, não havendo ainda condenação ou absolvição dos réus.

Um segundo crime ocorreria no CCLA em 08 de agosto de 2013. Quadra (2013) relata que 5 bandidos armados invadiram a Biblioteca do CCLA e levaram aproximadamente 100 obras. Algumas não estavam catalogadas e por isso não era possível dizer o total e os títulos corretamente. Cerca de 15 pessoas foram feitas reféns, sendo amarradas e trancadas. A ação começou às 16 horas e durou aproximadamente 1 hora e 15 minutos.

Brandt (2013a) dá notícia de que entre as obras levadas estavam 11 livros de botânica do séc. XVII, que já haviam sido furtadas em outra ocasião e devolvidas ao CCLA pela Polícia Federal. Provavelmente se trata do título Flora Fluminenses, de Josepho Mariano a Conceptione Vellozo, mencionado acima. O autor também diz que muitas das obras roubadas pertenciam ao Museu Campos Sales, que fica no CCLA, e que entre elas estava a carta do imperador chinês Guangxu ao expresidente e um volume sobre história da Dinastia Romanov, presenteada a Campos Sales pelo Czar Nicoulau II.

Em Cozer (2014) é possível verificar que apenas os quadros foram recuperados; ou seja, dos livros levados, nenhum foi reavido pela instituição. A autora diz que um dos suspeitos pela ação, preso em flagrante em uma outra ação de furto, é o mesmo que teria sido o mentor de vários outros crimes mencionados 
neste trabalho, como o do Instituto de Pesquisas Jardim Botânico do Rio de Janeiro e do Palácio do Itamaraty, entre outros.

Brandt (2013b) diz que foram presos 4 suspeitos do roubo ao CCLA. O autor diz que os criminosos foram presos em flagrante, no dia 06 de novembro de 2013, tentando roubar artes sacras da casa de um padre. A notícia só apresenta a recuperação de 39 quadros, mas não apresenta qualquer informação sobre a recuperação de livros raros.

Foi feito contato telefônico com o Diretor do CCLA que repassou o telefone de um delgado da Polícia Federal, que, segundo ele, estava envolvido nas instigações. Em contato telefônico com o delegado da PF, o mesmo disse que a investigação estava a cargo da Polícia Civil de Campinas, passando o telefone do delegado responsável. Foi feito contato telefônico e o envio de questionário por e-mail ao delegado da Polícia Civil de Campinas, em duas ocasiões, e também com a Secretaria de Segurança Pública de São Paulo, para tentar obter mais informações sobre o caso. No entanto, não houve resposta de ambas as partes. Portanto, não foi identificado qualquer processo judicial relacionado ao segundo crime ocorrido nesta instituição. Sendo assim, não é possível dizer sobre a condenação ou absolvição de qualquer suspeito.

\subsubsection{Instituições que responderam positivamente à questão 75 , sobre desaparecimento de livros raros}

$\mathrm{Na}$ questão 75 do questionário enviado para averiguar a Prevenção situacional nas instituições guardiãs de livros raros cadastradas no Planor, era perguntado sobre se ali havia algum caso de desaparecimento de livros raros. Houve, num primeiro momento, 21 instituições que responderam positivamente à questão. No entanto, em novo contato para envio de outro questionário, inquerindo sobre os detalhes do sumiço das obras, 3 disseram que não havia casos de desaparecimento de livros raros ali. Das 18 instituições restantes, 10 (55,55\%) responderam ao segundo questionário enviado. Para não revelar o nome das 
respondentes, as instituições serão numeradas de 1 a 10, conforme a ordem de resposta.

A Instituição 1 disse que houve um caso de desaparecimento de uma obra de Martinho Luthero publicada em 1521. A descoberta do ocorrido foi em momento de consulta ao acervo. Não houve instauração de inquérito policial.

A Insituição 2 informou que, no momento em que estavam fazendo o inventário de parte do acervo, os funcionários deixaram acumular exemplares sobre uma mesa. Depois verificaram que um livro com várias obras encadernadas juntas não estava lá. A área onde os livros estavam não tinha porta, mas o acesso era restrito aos funcionários. Não foi aberto inquérito policial.

A Instituição 3 acredita que houve muitos casos de furto de obras dos séculos XVI, XVII e XVIII, principalmente após a década de 1990, pois vários títulos que constavam em catálogos mais antigos não são encontrados no acervo. Não foi aberto inquérito policial.

A Instituição 4 relatou que houve um caso em que algumas obras foram para a restauração e durante o processo de compra dos materiais para realizar o serviço a restauradora faleceu e os livros não foram recuperados. Não houve abertura de inquérito policial sobre este caso.

A Instituição 5 respondeu que no ano de 1998 dois livros raros do século XIX foram furtadas e que outros materiais, como periódicos e fotos, foram levados em outros anos. Não houve instauração de inquérito policial para averiguar os fatos.

A Instituição 6 disse que esteve em vários endereços no período de 20 anos e que os livros permaneceram encaixotados por longo tempo. Por isso, feito o inventário, a listagem de livros presentes não bate com uma listagem antiga. Não foi aberto inquérito policial por este fato.

A Instituição 7 informou que o desaparecimento de obras ocorreu em um momento em que não havia controle do acervo e que o fato foi descoberto ao informatizar o catálogo. Não houve inquérito para apuração do ocorrido. 
A Instituição 8 relatou que o furto ocorreu na consulta de um exemplar por um usuário que se distanciou dos funcionários com o livro para melhor poder fotografar e, aproveitando da distração destes, fugiu com a obra. Não foi aberto inquérito policial para investigar o crime.

A Instituição 9 disse apenas que descobriram o desaparecimento do exemplar ao fazer a análise e seleção de obras, sem informar outros detalhes. Não foi aberto inquérito policial.

A Instituição 10 respondeu que, quando o acervo chegou à instituição, o mesmo era emprestado aos usuários. Por este motivo, hoje não é possível localizar algumas obras que estão registradas no catálogo. No entanto, não foi feito inventário para identificação de todas as obras desaparecidas. Como o fato ocorreu ao longo de muitos anos não foi aberto inquérito policial para averiguação dos fatos.

\subsection{Análise dos crimes}

Dos 15 crimes analisados, nota-se que a maioria deles, 8 (53,33\%) casos, aconteceram na cidade do Rio de Janeiro. As outras cidades com maior incidência de roubo e furto de livros raros são Campinas e São Paulo, ambas do Estado de São Paulo, com 2 (13,33\%) casos cada. Na cidade de Campinas os dois crimes ocorreram na mesma instituição e são os únicos casos que não aconteceram na capital de seus estados. A Região Centro-Oeste foi a única em que não houve algum caso de roubo e furto conhecido de livros raros. 
Figura 29 - Dispersão de casos por estado

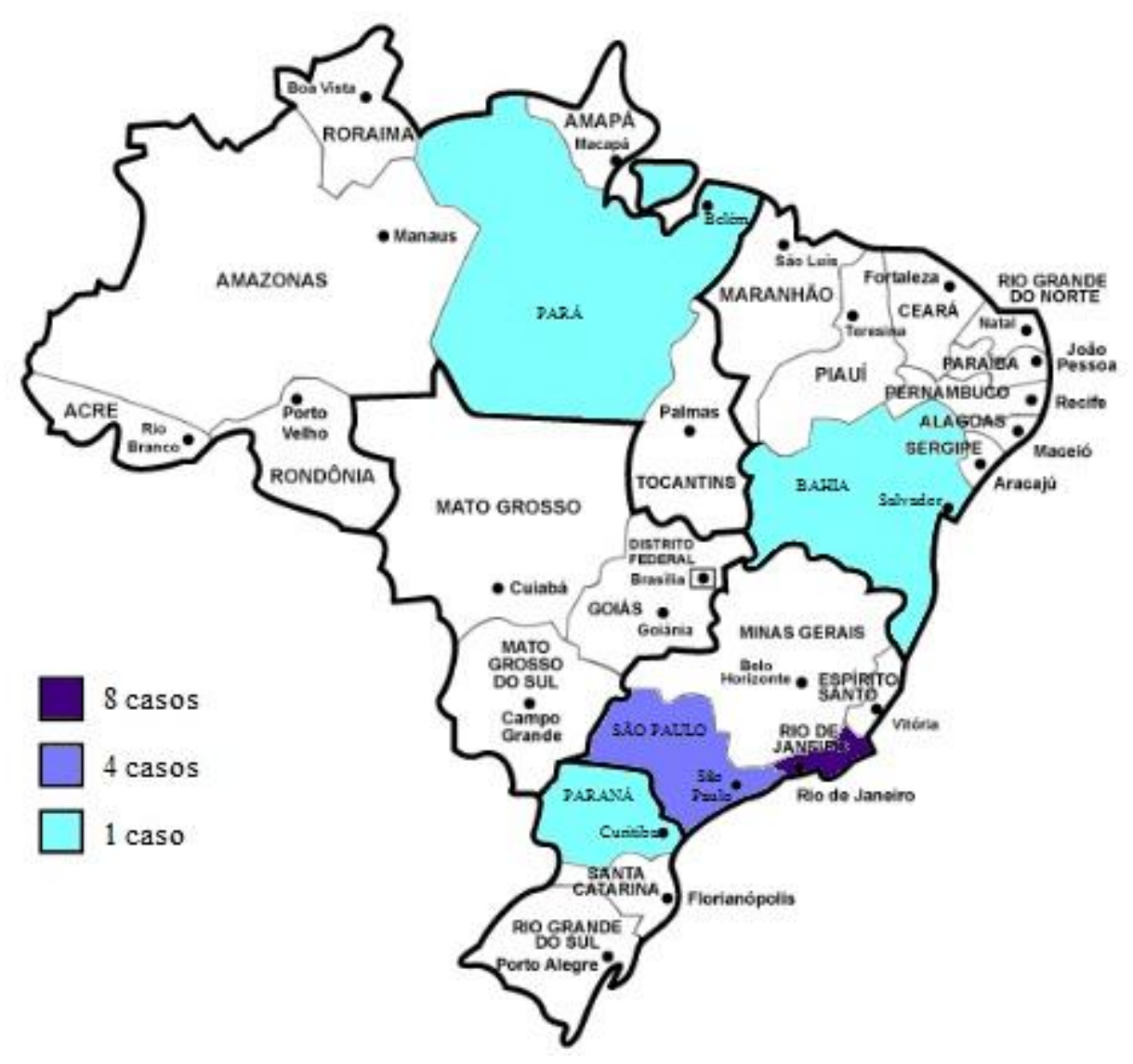

Fonte: do autor

No Quadro 7 abaixo, é possível ver um resumo comparativo de cada caso analisado, com o nome da instituição, o local onde esta se encontra, a data do crime ou de sua descoberta, a quantidade de livros raros levados, a quantidade de obras recuperadas, a quantidade de suspeitos indiciados e a pena adquirida em caso de condenação. Em alguns casos foi preciso usar o termo "não se aplica", para as informações que não foram possíveis averiguar, seja por ainda não fazerem parte do processo ou por não serem encontradas em nenhum dos documentos analisados.

A quantidade de livros subtraídos e recuperados, mostrada no quadro 7 abaixo, representa o que foi encontrado nos processos judiciais analisados, nas notícias dadas pelas próprias instituições, notícias repassadas pela polícia e notícias vinculadas na mídia, principalmente em jornais de grande circulação, como a Folha de São Paulo e o Estadão. Portanto, as quantidades podem não corresponder a quantidade real de obras roubadas ou furtadas e também de títulos resgatados. 
Assim como também podem não corresponder ao número exato a quantidade de suspeitos. A quantidade de livros levados, corresponde ao total de exemplares completos levados, tendo sido desconsiderado neste quadro as folhas ou gravuras retiradas dos livros, pela dificuldade em precisar quanto delas foi subtraído e quanto foi devolvido.

No Quadro 7 abaixo, todos os casos em que há uma quantidade estabelecida de suspeitos correspondem teoricamente a integrantes de uma mesma quadrilha. Nota-se, portanto, que em um primeiro momento as ações entre os anos 2003 e 2008 correspondem a furtos, pois não há uso de violência. O modus operandi inicial da quadrilha correspondia principalmente à aproximação das vítimas para ganho de sua confiança, como, por exemplo, nos casos do Instituto de Pesquisas Jardim Botânico do Rio de Janeiro; do Museu Histórico Nacional, em que um dos suspeitos se voluntariou para estagiar lá; no Museu Nacional da UFRJ; na Biblioteca Pública do Paraná, em cuja sentença o juiz alega que houve fraude pela busca em ganhar a confiança dos funcionários; ou mesmo no IGHB, em que os suspeitos falaram ter amigos em comum com a diretora da instituição, inclusive dando nomes.

Posteriormente é verificável uma mudança de abordagem, onde o crime praticado passa de furto qualificado para roubo à mão armada, como aconteceu nos casos mais recentes de que se tem notícia sobre a ação desta quadrilha, como no caso do Instituto de Botânica de São Paulo, no CCLA e no desdobramento do furto feito na Fiocruz, em que as obras são apreendidas na Aduana Iguazú e integrantes da quadrilha tentam recuperá-las. 
Quadro 6 - Comparativo entre os crimes

\begin{tabular}{|c|c|c|c|c|c|c|c|}
\hline Instituição & Cidade/Estado & Data & Descoberta do crime & $\begin{array}{l}\text { Quantidade de livros } \\
\text { subtraídos }\end{array}$ & $\begin{array}{c}\text { Quantidade de } \\
\text { livros recuperados }\end{array}$ & $\begin{array}{c}\text { Quantidade } \\
\text { de suspeitos }\end{array}$ & Condenação \\
\hline $\begin{array}{lr}\text { Instituto } & \text { de } \\
\text { Pesquisas } & \text { Jardim } \\
\text { Botânico } & \\
\end{array}$ & Rio de Janeiro/RJ & Nov. 2003 & Inventário & $5 \mathrm{ex}$. & 4 ex. & 2 & $\begin{array}{l}5 \quad \text { anos de } \\
\text { reclusão } \\
60 \text { dias-multas }\end{array}$ \\
\hline $\begin{array}{ll}\text { Palácio } & \text { do } \\
\text { Itamaraty } & \end{array}$ & Rio de Janeiro/RJ & Jul. 2003 & $\begin{array}{l}\text { Funcionário deu falta das } \\
\text { obras }\end{array}$ & $13 \mathrm{ex}$. & $\begin{array}{l}1 \text { ex. e partes de } \\
\text { outro }\end{array}$ & 2 & $\begin{array}{l}5 \quad \text { anos de } \\
\text { reclusão } \\
185 \text { dias-multas }\end{array}$ \\
\hline $\begin{array}{ll}\text { Museu } & \text { Histórico } \\
\text { Nacional } & \end{array}$ & Rio de Janeiro/RJ & Jun. 2004 & $\begin{array}{l}\text { Obras encontradas por } \\
\text { acaso em outra instituição } \\
\text { que as mantinha como fiel } \\
\text { depositário }\end{array}$ & 1 ex. & 1 ex. & 2 & Não se aplica \\
\hline $\begin{array}{l}\text { Museu Nacional - } \\
\text { UFRJ }\end{array}$ & Rio de Janeiro/RJ & 20 abr. 2004 & $\begin{array}{l}\text { Solicitação de consulta de } \\
\text { obra por um usuário }\end{array}$ & $\begin{array}{l}12 \text { in-fólios (sumidos) } \\
39 \text { in-fólios (danificados) } \\
10 \text { obras raras (sumidas) }\end{array}$ & $\begin{array}{l}9 \text { in-fólios } \\
489 \text { pranchas/folhas } \\
50 \text { folhas de texto }\end{array}$ & 6 & Não se aplica \\
\hline EBA - UFRJ & Rio de Janeiro/RJ & 22 fev. 2006 & $\begin{array}{l}\text { Ausência das usuárias } \\
\text { que estavam consultando } \\
\text { as obras }\end{array}$ & 1 & 1 & 2 & Não se aplica \\
\hline AGCRJ & Rio de Janeiro/RJ & Jun. 2006 & $\begin{array}{l}\text { Funcionário deu falta das } \\
\text { obras }\end{array}$ & 2 & 1 & Não se aplica & Não se aplica \\
\hline $\begin{array}{l}\text { Biblioteca Mário de } \\
\text { Andrade }\end{array}$ & São Paulo/SP & 06 jul. 2006 & $\begin{array}{l}\text { Solicitação de empréstimo } \\
\text { de uma obra para } \\
\text { exposição }\end{array}$ & $\begin{array}{l}107 \text { gravuras retiradas de } \\
5 \text { títulos e } 1 \text { ex. }\end{array}$ & 23 gravuras & Não se aplica & Não se aplica \\
\hline $\begin{array}{ll}\text { Biblioteca } & \text { Pública } \\
\text { do Paraná } & \end{array}$ & Curitiba/PR & Out. 2006 & $\begin{array}{l}\text { Funcionário deu falta das } \\
\text { obras }\end{array}$ & $68 \mathrm{ex}$. & 0 & 2 & $\begin{array}{l}4 \quad \text { anos de } \\
\text { reclusão } \\
20 \text { dias-multas } \\
\text { Pena substituída* }\end{array}$ \\
\hline $\begin{array}{l}\text { Museu Chácara do } \\
\text { Céu }\end{array}$ & Rio de Janeiro/RJ & 24 fev. 2006 & Assalto à mão armada & 1 & 0 & 0 & Não se aplica \\
\hline Fiocruz & Rio de Janeiro/RJ & 2007 & $\begin{array}{l}\text { Comunicado do Iphan } \\
\text { sobre a recuperação das } \\
\text { obras }\end{array}$ & 250 & 138 & 4 & $\begin{array}{l}5 \text { anos e } 4 \text { meses } \\
\text { (na Argentina) }\end{array}$ \\
\hline IGHB & Salvador/BA & Set. 2007 & $\begin{array}{l}\text { Contato de jornal sobre } \\
\text { obras recuperadas }\end{array}$ & $12 \mathrm{ex}$. & $12 \mathrm{ex}$. & 5 & Não se aplica \\
\hline $\begin{array}{l}\text { Museu Paraense } \\
\text { Emílio Goeldi }\end{array}$ & Belém/PA & 17 dez. 2008 & $\begin{array}{l}\text { Treinamento } \\
\text { funcionários }\end{array}$ & 65 ex. & $1 \mathrm{ex}$. & 0 & Não se aplica \\
\hline $\begin{array}{l}\text { Instituto de Botânica } \\
\text { de SP }\end{array}$ & São Paulo/SP & 02 fev. 2012 & Assalto à mão armada & 27 ex. & 27 ex. & 3 & Não se aplica \\
\hline \multirow[t]{2}{*}{ CCLA } & \multirow[t]{2}{*}{ Campinas/SP } & 07 jun. 2004 & $\begin{array}{l}\text { Comunicado da PF sobre } \\
\text { recuperação das obras }\end{array}$ & $15 \mathrm{ex}$. & $15 \mathrm{ex}$. & 6 & Não se aplica \\
\hline & & 08 ago. 2013 & Assalto à mão armada & $11 \mathrm{ex}$. & 0 & 1 & Não se aplica \\
\hline
\end{tabular}

* Pena substituída por prestação de serviços comunitários e multa de 10 salários mínimos

Fonte: Do autor 
Por meio do quadro 7 acima é possível ver que 2006 foi o ano em que mais houve casos de roubo e furto de livros raros, com $1 / 3$ dos 15 crimes analisados. No gráfico 1 abaixo é possível ver a dispersão da quantidade de crimes por ano, nos estados onde ocorreram os mesmos.

Gráfico 1 - Dispersão de crimes por ano e estado

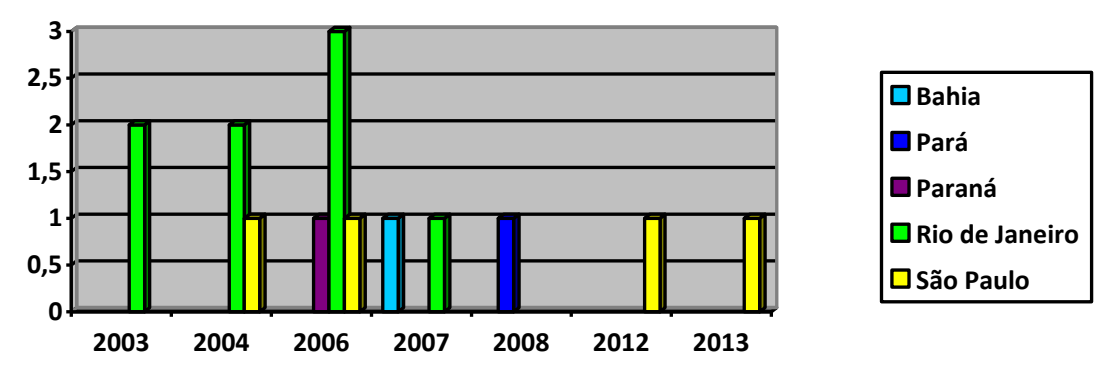

Fonte: Do autor

Ao verificar a listagem das obras subtraídas nos casos analisados é possível verificar que alguns títulos foram furtados ou roubados em mais de uma instituição. Esta informação pode ser útil para que outras instituições que possuam exemplares destas obras as coloquem sobre maior proteção. Os títulos levados em mais de uma instituição são:

1 Scenas da Vida Carioca: levado do Museu Histórico Nacional e do AGCRJ;

2 Rerum per octennium in Brasília et alibi nuper gestarum...: levado do Museu Nacional da UFRJ e do IGHB. Também foi subtraído da Biblioteca Pública do Paraná um fac-simile desta obra;

3 Ornithologie bresilienne, ou, histoire des oiseaux du Bresil, remarquable par leur plumage, leur chant ou lers habitudes: levado do Museu Nacional da UFRJ e da Escola de Belas Artes da UFRJ;

4 Avium species novae quas in itinere annis...: levado do Museu Nacional da UFRJ e da Biblioteca Pública do Paraná; 
5 Histoire naturelle des signes et des makis...: levado do Museu Nacional da UFRJ e da Biblioteca Pública do Paraná;

6 Atlas zur reise in Brasilien...: levado do Museu Nacional da UFRJ e da Biblioteca Mario de Andrade;

7 Plantarum brasiliae icons et descriptions hactenus ineditae...: levado do Museu Nacional da UFRJ e do Instituto de Botânica de São Paulo;

8 Erläuterungen zur Fauna Brasiliens: levado do Museu Nacional da UFRJ e da Biblioteca Mario de Andrade;

9 Malerisches Reise in Brasilien: levado da Biblioteca Mário de Andrade e do IGHB;

10 Flora Fluminensis: levado do Instituto de Botânica de São Paulo e do CCLA;

11 Sertum Palmarum Brasiliensium: levado da Fiocruz e do Instituto de Botânica de São Paulo.

Nota-se a organização desta quadrilha na execução dos crimes, que demonstram ações planejadas de pessoas que têm conhecimento de como funcionam as instituições e o comércio de antiguidades. O mentor desta quadrilha foi aluno de Biblioteconomia, estagiou na Biblioteca Mário de Andrade e teve comércio de revistas e livros antigos. Há o estudo das vítimas, pois os mesmos frequentam os locais por longos períodos, fazendo mais de uma visita. O estudo é tamanho que no caso do IGHB, como já citado, os criminosos disseram conhecer amigos da diretora desta instituição, que residem em Santos, apontando o nome dos mesmos.

A quadrilha demonstra ter muito conhecimento do mercado de antiguidades, principalmente de livros e periódicos, pois vários são os comerciantes que devolveram obras após tomarem conhecimento dos crimes. Dois leiloeiros que entregaram livros à polícia espontaneamente, depois de saberem de notícias sobre a prisão dos criminosos, diz que um dos suspeitos demonstrava conhecer muitas pessoas do comércio de antiguidades. Houve o indiciamento judicial e criminal de um comerciante que estaria de posse de obras vendidas pelos criminosos. Este 
comerciante teria tido conhecimento da ilegalidade do ato, mas mesmo assim preferiu entrar em contato com os criminosos ao invés da polícia. Este mesmo comerciante ainda teria feito procedimentos de restauração nas obras para ocultar marcas de propriedade. Exemplares que posteriormente seriam identificados como pertencentes ao CCLA. Nota-se também, no caso da Fiocruz, que as obras já estavam cruzando a fronteira entre Brasil e Argentina para comércio internacional das mesmas.

Apesar de não ter sido comprovado em nenhum dos casos a participação de funcionários nos atos criminosos, houve desconfiança em vários deles, pois em muitos destes casos a quantidade de obras e mesmo as dimensões físicas delas não permitiriam a saída delas da instituição sem que alguém notasse, como aconteceu, por exemplo, nos casos do Palácio do Itamaraty, da Biblioteca Mário de Andrade e da Fiocruz. Portanto, na análise destes crimes é possível ver a importância em se ter uma prevenção situacional bem estruturada, pois em nenhum dos processos jurídicos analisados houve a indicação do reconhecimento dos suspeitos, ou mesmo da ação criminosa por meio de câmeras de vigilância. Em alguns crimes como, por exemplo, o ocorrido no Instituto de Pesquisas Jardim Botânico do Rio de Janeiro, o reconhecimento dos suspeitos ocorreu em notícia que relatava à prisão destes; ou seja, a câmera por si só não evita o crime, mas pode ajudar no reconhecimento dos suspeitos e vinculá-los à ação criminosa. Assim como, também pode em alguns casos evitar que ação se conclua, desde que haja uma equipe capacitada a identificar e atuar neste momento.

Uma boa prevenção situacional torna-se cada vez mais importante, pois nos casos de roubo e furto, mesmo que a eficácia policial seja alta, numa situação utópica de recuperação de todas as obras e haja rigor judicial, com condenação rápida e de alto grau punitivo, já houve danos às obras. É possível ver, por exemplo, no caso do Itamaraty, que há o desmembramento de várias gravuras presentes em livros, assim como o de pranchas e folhas, como também ocorreu no Museu Nacional da UFRJ. No Arquivo Geral da Cidade do Rio de Janeiro há relatos de recorte de fotos e capas arrancadas de alguns álbuns. E as obras recuperadas do Instituto de Pesquisas Jardim Botânico do Rio de Janeiro, do Museu Histórico 
Nacional e no primeiro crime ao CCLA apresentavam sinais de restauração, com alteração física e química do papel, para tentar retirar as marcas de propriedade.

Nos crimes relatados pelas instituições que responderam positivamente à questão 75 do questionário sobre prevenção situacional, nota-se que é preciso fazer o controle adequado das coleções periodicamente, além de ser feito um estudo prévio sobre a importância das obras e como serão realizados os processo técnicos. Nas Instituições 4 e 5 é possível ver a falta de planejamento sobre a conservação das obras de um modo geral, pois na primeira instituição a obra vai para a restauração e durante a aquisição de material a restauradora morre e a obra nunca é resgatada e na segunda as obras eram emprestadas. Nos casos das Instituições 3, 6 e 7 é possível ver que elas nem sempre fazem controle periódico da coleção, pois os desaparecimentos de obras são descobertos muito tempo após o acontecido. Nestes casos verifica-se a importância de um controle mínimo, como por exemplo, a fotobibliografia, para que seja possível a realização de ao menos um inventário topográfico.

Em alguns casos também é possível ver que a quantidade de crimes é bem maior que a averiguada neste trabalho e que algumas instituições não tratam como tal, pois não abrem inquérito policial para averiguação dos fatos. Casos como estes aconteceram na Instituição 2, em que as obras se acumularam durante um processo técnico, verificando-se o sumiço de alguns exemplares devido à perda de controle sobre estes. Assim, como também na Instituição 5, há o relato de que em 1998 houve dois livros raros furtados. A instituição 8 também diz que em uma consulta um usuário pediu para fotografar uma obra e se aproveitando da distração dos funcionários furtou-a. Nenhuma destas três instituições abriram inquérito policial.

\subsubsection{Análise dos crimes: Eficácia Policial}

A análise da eficácia policial é feita, por meio da análise do índice de prisão em relação aos crimes ocorridos e o índice de recuperação de obras em relação à quantidade roubada ou furtada. 
Como dito anteriormente, dos 15 crimes analisados, em pelo menos 11 (73,33\%), existem indícios da participação de uma mesma quadrilha especializada neste tipo de roubo e furto. Nos processos judiciais, nas notícias vinculadas à mídia e nas notícias passadas pelas instituições, foi possível averiguar que há um suspeito comum em 10 dos 11 casos em que atuou esta quadrilha. Esta pessoa é considerada o mentor da organização criminosa. Foi possível averiguar a participação nesta quadrilha de pelos menos 15 pessoas, a maioria delas sendo indiciada em mais de um dos crimes.

Não é possível determinar com exatidão a quantidade de obras subtraídas, pois em alguns casos como, por exemplo, no IGHB, só se teve acesso em processo judicial à notícia de uma primeira devolução de obras. Enquanto, em contato telefônico à Diretora desta instituição, alega ter ocorrido uma segunda remessa de obras devolvidas sem especificar a quantidade. Em alguns casos, como o do CCLA em 2004, em que a instituição só teve notícia do caso após a apreensão das obras e faz o Boletim de Ocorrência na Polícia Civil indicando o desaparecimento apenas das obras indicadas no auto de apreensão, não é possível dizer se houve outras obras subtraídas e não indicadas pela instituição.

Diante dos dados recolhidos nos processos judiciais, em matérias jornalísticas, junto às instituições e com as autoridades policiais é possível informar com segurança, que em apenas $5(33,33 \%)$ casos, dos 15 crimes analisados, todas as obras foram recuperadas. Foi possível identificar que pelo menos 496 exemplares completos foram roubados ou furtados das instituições e que apenas $210(42,34 \%)$ exemplares completos foram recuperados.

Para fins de comparação, no estado de São Paulo, segundo dados registrados no site da Secretaria de Segurança Pública ${ }^{44}$ deste estado, a quantidade de ocorrências para roubos de veículos no ano de 2014, até o mês de maio, foi de 44.771 , enquanto o número de furtos de veículos foi de 53.345, o que somados dão 98.116 ocorrências envolvendo roubo e furto de veículos em 5 meses. Enquanto

\footnotetext{
${ }^{44}$ Site da Secretaria de Segurança Pública de São Paulo: http://www.ssp.sp.gov.br/. Acesso em: 14 jul. 2014.
} 
43.310 é o número de veículos recuperados nestes mesmos 5 meses. Não é possível dizer se os veículos recuperados nestes meses correspondem apenas as ocorrências feitas nestes mesmos meses, o que provavelmente não acontece. Mas, caso fossem, teriam sido solucionados $44,14 \%$ dos casos; ou seja, o índice de recuperação de livros raros estaria abaixo deste índice.

Segundo Martí (2012) em entrevista com o diretor do The art loss register, as obras de arte roubadas são recuperadas em $20 \%$ dos casos. Portanto, estes itens que se assemelham mais ao livro raro quanto à sua natureza, do que os veículos acima citados, não são recuperados geralmente na mesma proporção que foram os livros levados nos casos analisados. No Banco de Dados de Consulta a Bens Culturais Procurados do Iphan, como já citado, é possível ver a quantidade de obras registradas que se encontram desaparecidas e quantas destas foram recuperadas. Das 1723 obras registradas, apenas 127 foram recuperadas, sendo que 1596 ainda encontram-se desaparecidas; ou seja, das obras cadastradas neste bando de dados o índice de recuperação é de $7,37 \%$ das obras desaparecidas ${ }^{45}$. O fato de ter uma quadrilha envolvida na maioria dos casos de roubo e furto de livros raros, aumentam as chances policiais na recuperação das obras, caso ocorra a prisão de um dos envolvidos, como foi o caso, pois uma grande quantidade destas estão reunidas na mão de poucos, o que seria diferente se cada crime tivesse sido cometido por diferentes pessoas sem qualquer ligação entre elas. Isto é averiguável nos casos como o do Museu Chácara do Céu ou do Museu Paraense Emílio Goeldi, em que não há indícios da participação dessa quadrilha e houve recuperação de apenas um livro de pelo menos 69 exemplares levados. Também não houve indiciamento de nenhum suspeito.

Não existem índices nacionais seguros para comparação da taxa de recuperação de livros raros com o de outros bens, ou mesmo de bens culturais. A eficácia policial, diante do que se pode analisar, está dentro do esperado para os casos de roubo e furto ao patrimônio de um modo geral e acima da média mundial de recuperação de bens culturais roubados e bem acima da média de recuperação

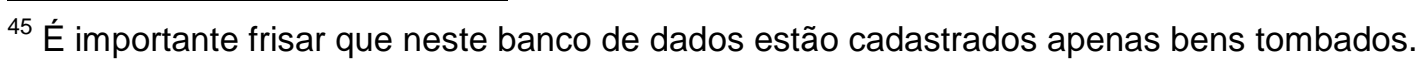


da obras cadastras no banco de dados do Iphan. No entanto, devido ao valor cultural e histórico das obras e a perda de memória histórica causada pela subtração delas, não é possível dizer convictamente que a polícia é eficaz, pois o índice ideal de recuperação de obras únicas é utópico, ou seja, seria o índice de $100 \%$, inclusive sem a incidência de qualquer dano a elas.

Quanto ao índice de prisão não é possível estabelecer com exatidão. Em todos os sete processos, que foi possível ter acesso na íntegra, vê-se que foi aceito pelo juiz o pedido de prisão preventiva. No entanto, nem sempre é possível determinar se os suspeitos foram presos por aquele pedido, ou mesmo se já se encontravam presos. Alguns dos suspeitos foram presos em mais de uma ocasião, pois como visto participaram de mais de um crime. O índice de prisão indica parte da eficácia da polícia seguindo o raciocínio que o criminoso estaria pagando por sua culpa e que o mesmo não estaria cometendo outro crime naquele momento, além de estar sendo reeducado para não exercer mais a atividade criminosa. No entanto, como afirma em entrevista o Entrevistado D, delegado da Polícia Federal, apesar da importância de prender os culpados, é mais importante recuperar a obra, pois em alguns casos é uma obra única.

A prisão com foco em que o criminoso não cometa novos crimes só é eficaz caso o sistema prisional seja também eficiente. Os crimes de roubo e furto de livros raros entre os anos de 2007 a 2012 em que esteve envolvida a quadrilha já mencionada eram comandados pelo seu mentor que se encontrava preso neste período. Portanto, de dentro da prisão ele comandava os crimes por meio de telefone celular, cartas e nas visitas que recebia, conforme mostram Brito e Martins (2012); ou seja, neste caso a prisão do mentor não funcionou como meio para que o mesmo não cometesse crimes durante seu período de detenção e também não o reeducou. Como é visto nas notícias que mostram seu envolvimento em crimes posteriores a sua libertação, por exemplo, os casos do Instituto de Botânica de São Paulo e do CCLA. 


\subsubsection{Análise dos crimes: Rigor Penal}

A análise do rigor penal é feita com relação aos julgamentos de processos judiciais, medindo a pena aplicada em relação ao crime cometido. Dos 15 crimes analisados, apenas 3 já têm sentença proferida no Brasil, o do Instituto de Pesquisas Jardim Botânico e do Palácio do Itamaraty, ocorridos em 2003, e o da Biblioteca Pública do Paraná, em 2006 (Anexos E, F e G).

O processo relacionado ao crime 1, no Instituto de Pesquisas Jardim Botânico, é o de no 0517641-33.2004.4.02.5101, presente na $2^{\text {a }}$ Vara Federal Criminal do Rio de Janeiro. Além do processo desmembrado 081534438.2008.4.02.5101, também na 2a Vara Federal Criminal. As sentenças proferidas em primeira instância, no dia 19 de novembro de 2008 e no dia 19 de fevereiro de 2009, condenaram os dois réus a 5 anos de reclusão e pagamento de 60 dias-multa. A denúncia oferecida pelo MPF qualificava os suspeitos nos crimes previstos no art. $155 \S 4^{\circ}$, incisos II e IV ${ }^{46}$ e art. 299, na forma dos artigos 29 e $69 .{ }^{47}$ A pena para o art. $155 \S 4^{\circ}$ é de dois a oito anos de reclusão e multa, assim como o do art. 299 é de um a cinco anos por se tratar de omissão de informação em documento público.

O juiz considerou certa a materialidade do crime de furto, mesmo não tendo sido encontradas com os acusados as obras subtraídas. Referindo-se como provas o laudo do exame grafotécnico que identificaram as assinaturas contidas nos documentos da instituição como sendo dos réus. Assim como, o juiz valorou o fato das testemunhas não quererem depor na frente de um dos réus, devido à intimidação praticada por ele. Quanto ao art. 299 o juiz diz:

Quanto ao crime previsto no art. 299 do CP, discordo da conclusão
externada pelo parquet em sua peça de alegações finais (fls. 561/572), por
entender que a falsidade ideológica foi o meio utilizado para a prática do
crime de furto, mediante adoção do critério da consunção, que tenciona
solucionar eventuais conflitos aparentes de normas. Sobre este tema,
pondera Juarez Cirino dos Santos que: "o critério da consunção resolve o

\footnotetext{
${ }^{46}$ No Código Penal o art. $155 \S 4^{\circ}$ corresponde ao furto qualificado, pois segundo a denúncia foi realizado com abuso de confiança, ou mediante fraude, escalada ou destreza, no inciso II e mediante concurso de duas ou mais pessoas, inciso IV.

${ }^{47}$ No Código Penal o art. 299 corresponde à falsidade ideológica. O art. 29 fala sobre o Concurso de Pessoas e 0 art. 69 sobre a participação do suspeito em dois crimes concomitantes.
} 
conflito aparente entre tipo consumidor e tipo consumido: o conteúdo de injusto do primeiro tipo consome o conteúdo de injusto do segundo, porque o tipo consumido constitui meio regular (não, porém, necessário) de realização do tipo consumidor (lex consumens derogat legi consumptae)"4. Sob esta ótica, portanto, o crime de furto qualificado (art. 155 e parágrafo do $C P$ ) seria o chamado "tipo consumidor", que absorveria o crime de falsidade ideológica (art. 299 do CP), que seria considerado apenas como mero ante factum impunível.

Ao proferir a sentença o juiz diz que fixa a pena-base acima do mínimo, justificando que:

[...] acolhendo a sugestão do MPF (fl. 571), realmente vislumbro a presença de dolo acima do normal, graves consequências dos ilícitos praticados (que para alguns seria até de valor inestimável, por se tratarem de obras únicas, conforme consta no depoimento que se encontra à fl. 553) e, também, em virtude da personalidade do agente ser claramente voltada para a prática de crimes desta espécie. Por todos estes motivos, fixo a pena-base acima do mínimo legal em 5 (cinco) anos de reclusão e pagamento de 60 (sessenta) dias-multas. (grifo do autor)

Ou seja, o juiz considera os atos condenáveis devido à importância das obras e pela perda irreparável destas com o crime cometido. O juiz não vê situação agravante ou atenuante, assim como também não vê motivos para aumento ou diminuição da pena. Portanto, devido ao tamanho desta não é possível substituição da pena privativa de liberdade por penas alternativas de direito, além do juiz considerar evidente que a substituição não é suficiente e adequada para garantir a prevenção geral e a própria aplicação da lei penal.

Em apelação à sentença proferida, o relator:

Deu parcial provimento à apelação para reduzir a pena aplicada ao réu para 3 (três) anos e 6 (seis) meses de reclusão e pagamento de 33 (trinta e três) dias-multa, no valor de um salário mínimo, com a substituição da pena privativa de liberdade por duas restritivas de direitos de prestação de serviços à comunidade e multa de 20 (vinte) dias-multa, por entender que a pena foi aplicada muito acima do mínimo legal sem uma justificativa legal ou jurisprudencial para tanto

No entanto, o relator foi voto vencido, pois a desembargadora responsável pelo acórdão considerou que a materialidade do crime estava comprovada e que a questão era sobre a dosimetria da pena, que as

graves conseqüências do crime também justificam a fixação da pena-base em quantum acima do mínimo legal, posto que as obras furtadas são de valor inestimável, tratando-se de obras únicas, como destacou a Diretora do Arquivo Geral da Cidade do Rio de Janeiro no depoimento de fls. 553/554. 
Portanto, foi negado o provimento do recurso, sendo mantida a sentença, com acórdão proferido em 09 de fevereiro de 2010. Também foram negados os embargos infringentes à manutenção da pena na apelação; ou seja, também foi mantida a pena, em acórdão emitido em 03 de dezembro de 2010.

No caso do crime 2, no Palácio do Itamaraty do Rio de Janeiro, o MPF pediu condenação dos réus às penas do art. $155, \S, 4^{\circ}$, inciso IV. Que como visto anteriormente a pena é de dois a oito anos de reclusão e multa. Na denúncia do MPF é alegado que os réus subtraíram mais de 60 documentos raros cartográficos e 2.350 documentos iconográficos do patrimônio da União, sob a guarda do Ministério das Relações. Há dois réus que foram julgados pelos processos desmembrados 0807693-18.2009.4.02.5101 e 0513911-48.2003.4.02.5101, ambos na 6 $6^{\underline{a}}$ Vara Federal Criminal do Rio de Janeiro. Um dos réus também foi julgado e condenado no crime relatado anteriormente.

Em ambas as sentenças, proferidas no dia 20 de abril de 2010, o juiz determina que não é possível imputar aos réus a subtração dos 60 documentos cartográficos e dos 2.350 documentos iconográficos, pois devido ao tamanho das obras os réus não conseguiriam furtá-las sem a ajuda de algum funcionário, o que não foi averiguado durante o processo. No entanto, só podem ser atribuídos aos réus o furto de sete mapas e duas alegorias do atlas de Van Keulen, pois estas peças foram apreendidas na residência de um dos réus junto com obras de outras instituições. O juiz diz que o motivo para o crime é a "ganância e busca da riqueza fácil".

O juiz acentua a culpabilidade do réu devido as circunstâncias e consequências do crime, pois os suspeitos agiram de forma premeditada e cuidadosamente planejada, com a estratégia de se aproximar dos funcionários, ganhando sua confiança e estudando as obras mais valiosas do acervo. O juiz ainda diz sobre a importância das obras:

As consequências do crime também são gravíssimas. Ainda que não seja possível a este Juízo precisar o valor das ilustrações subtraídas, especialmente aquelas que não foram recuperadas, é certo que são peças raríssimas, todas componentes do Atlas de Johanes Van Keulen, que tem somente seis exemplares em todo o mundo, um dos quais estava na guarda da Mapoteca do Ministério das Relações Exteriores.. Na realidade seu valor 
transcende a pecúnia. O Atlas e cada uma de suas gravuras são integrantes do patrimônio histórico e cultural do Brasil e, nessa medida, insubstituíveis. $\mathrm{E}$ duas das peças subtraídas pelo réu não foram ainda recuperadas. As circunstâncias sopesadas acima revelam que a ação criminosa apresenta, em concreto, uma gravidade muitas vezes superior às lesões a patrimônios privados que ocorrem cotidianamente.

O juiz determina uma pena na média entre a pena mínima e a máxima, devido ao crime ser duplamente qualificado, pelo concurso de pessoas e pela fraude como meio de execução. A pena aplicada foi de 5 anos de reclusão em regime inicial fechado e pagamento de 185 dias-multa. Devido ao tamanho da pena é impossibilitada a substituição da mesma. Houve apelação de ambos os réus e também pelo MPF, que disse que na sentença deixou de majorar a pena em:

\begin{abstract}
um sexto a dois terços prevista no art. 71 do Código Penal, por tratar-se de crime continuado. Defende, para tanto, que para a ocorrência do crime continuado é indispensável a prática sucessiva de ações criminosas da mesma espécie que guardem, entre si, conexões no tocante ao tempo, ao lugar e ao modo de execução, de modo a revelar homogeneidade das condutas típicas, sendo o que realmente ocorreu no caso em tela, visto que o acusado entre os meses de abril e julho compareceu 19 (dezenove) vezes na Mapoteca do Palácio do Itamaraty, não sendo crível que tenha subtraído todos os objetos de uma única vez. Requer, assim, que seja considerada a exasperação da pena no patamar compreendido entre um sexto e dois terços a partir da pena-base de 5 anos.
\end{abstract}

Em acórdãos proferidos em 24 de novembro de 2010, na apelação criminal ํㅡㄴ ACR/8022, e 23 de fevereiro de 2011, na apelação criminal ํo ACR/8341, foram negados unanimemente os pedidos de diminuição da pena pelos réus e também a majoração da pena pelo MPF, mantendo-se a pena proferida em primeira instância. O juiz alegou que não era possível determinar que os nove mapas e as duas alegorias do atlas Van Keulen foram furtados em mais de uma ocasião, já que os réus foram absolvidos da subtração de todas as outras obras indicadas na denúncia. Em 18 de fevereiro de 2011, na apelação criminal no ACR/8022, foi admitido recurso especial $^{48}$ de um dos réus e em 10 de maio de 2011 não foi admitido o recurso especial do outro réu, na apelação criminal no ACR/8341. Foi negado o segmento do

${ }^{48}$ Art. 105. Compete ao Superior Tribunal de Justiça:

$[\ldots]$

III - julgar, em recurso especial, as causas decididas, em única ou última instância, pelos Tribunais Regionais Federais ou pelos tribunais dos Estados, do Distrito Federal e Territórios, quando a decisão recorrida:

a) contrariar tratado ou lei federal, ou negar-Ihes vigência;

b) julgar válido ato de governo local contestado em face de lei federal;

c) der a lei federal interpretação divergente da que Ihe haja atribuído outro tribunal. (CONSTITUIÇÃO

FEDERAL, 1988, online) 
recurso especial, antes aceito, pelo Superior Tribunal de Justiça (STJ), na decisão do recurso especial no 1256898/RJ, em 14 de novembro de 2013.

No crime 3, na Biblioteca Pública do Paraná, o processo originário que condenou os dois réus indiciados é o de ํㅡㄹ 2007.0003086-7 da 11르 Vara Criminal do Foro Central de Curitiba no Paraná. Um dos réus estava envolvido nos dois crimes tratados anteriormente. O processo foi desmembrado para um dos réus, mas não foi possível identificar o mesmo no Tribunal de Justiça do Paraná. Portanto, a decisão aqui analisada é para um dos réus, aquele que participou dos outros dois crimes e que também é considerado o mentor da quadrilha que participou de vários outros roubos e furtos de livros raros.

O réu foi indiciado pela prática do crime previsto no art. $155, \S 4^{\circ}$, dos incisos II e IV do Código Penal. O juiz relatou que é qualificadora de fraude, pois o réu retirou os livros abusando da confiança das funcionárias iludindo a atenção dos responsáveis pela vigilância das obras. Ao estabelecer a pena o juiz diz que quanto à culpabilidade o réu agiu com plena consciência da ilicitude dos seus atos. Para ele o motivo do crime foi a busca do lucro fácil em detrimento do patrimônio público. O juiz ainda diz que "as consequências foram elevadas, uma vez que o patrimônio cultural do país restou prejudicado com a prática do delito, prejudicando a história da nação." A pena estabelecida, na sentença proferida em 24 de março de 2010, foi de 4 anos de reclusão e 120 dias-multa, começando em regime aberto, sendo substituída por uma pena restritiva de direito, constante em prestação de serviços à comunidade e prestação pecuniária em 10 salários mínimos a serem pagos a uma entidade de assistência social. Após recurso interposto, em 20 de dezembro de 2010, houve manutenção da pena, como é possível ver na Guia de Recolhimento Provisória assinada, em 29 de abril de 2011, pelo Juiz que expediu a sentença.

\subsubsection{Dosimetria da pena}

A dosimetria da pena cabe ao juiz do caso estabelecer, dentro do intervalo de pena que o Código Penal Brasileiro permite. Neste trabalho não há a tentativa de estabelecer a assertividade ou não da dosimetria aplicada em uma pena. Mas, tentar 
entender como essa pena é estipulada e se haveria possibilidade de uma majoração desta. Sem entrar no mérito se a pena restritiva de liberdade é mais eficaz que a pena substitutiva, do ponto de vista educativo e ressocialização do réu, o presente trabalho parte do pressuposto que o juiz majora a pena dentro da percepção de danos e consequências do crime; ou seja, quanto maior a pena, mais danoso foi considerado o ato criminoso. Já que, a pena é o equilíbrio entre a retribuição do mal acometido pelos criminosos e a prevenção, com a intimidação da população a não cometer o mesmo crime e tentativa de impedir que o condenado volte a delinquir, por estar preso e/ou por ser ressocializado, como mostram Azevedo e Furlan (2013). Serão analisadas as sentenças e penas proferidas ao réu que participou de todos os três crimes (Anexos E, F e G).

As penas dos três julgamentos correspondem, portanto, ao crime de furto qualificado. Sendo assim, o art. $155 \S^{\circ}$ ํ do Código Penal estabelece a pena mínima de 2 anos de reclusão e multa e a máxima de 8 anos de reclusão e multa. A multa, segundo o art. 49 do Código Penal pode ser:

Art. 49 - A pena de multa consiste no pagamento ao fundo penitenciário da
quantia fixada na sentença e calculada em dias-multa. Será, no mínimo, de
10 (dez) e, no máximo, de 360 (trezentos e sessenta) dias-multa.
$\S 1^{\circ}-$ O valor do dia-multa será fixado pelo juiz não podendo ser inferior a
um trigésimo do maior salário mínimo mensal vigente ao tempo do fato, nem
superior a 5 (cinco) vezes esse salário.
$\S 2^{\circ}$ - O valor da multa será atualizado, quando da execução, pelos índices
de correção monetária.

A dosimetria da pena, portanto, é determinada pela análise abstrata do juiz feita em 3 fases. Aguiar Júnior (2001, p. 170) mostra que o cálculo da pena obedece "ao método preconizado no art. 68: $1^{\circ}$ ) pena-base, com as circunstâncias judiciais do art. 59; $2^{\circ}$ ) pena provisória, com as circunstâncias agravantes e atenuantes da parte geral; $3^{\circ}$ ) pena definitiva, com as causas de aumento ou de diminuição." O art. 59 do Código Penal usado para a aplicação da pena-base diz que o juiz deve aplicar a pena levando em consideração "à culpabilidade, aos antecedentes, à conduta social, à personalidade do agente, aos motivos, às circunstâncias e conseqüências do crime, bem como ao comportamento da vítima, estabelecerá, conforme seja necessário e suficiente para reprovação e prevenção do crime." Para Aguiar Júnior (2001, p. 165-167) a definição de cada item do art. 59 corresponde a: 
Culpabilidade: o conjunto de circunstâncias que tornam mais ou menos reprovável a conduta do agente.

Antecedentes: são os fatos registrados sobre o comportamento anterior do réu, integram a sua história de vida e já não podem ser modificados, apenas conhecidos e avaliados, sempre na perspectiva do crime que está em julgamento.

Conduta social: modo pelo qual o agente exerceu os papéis que lhes foram reservados na sociedade. Trata-se de averiguar, por meio dessa circunstância, o seu desempenho na sociedade, em família, no trabalho, no grupo comunitário, formando um conjunto de fatores do qual talvez não tenha surgido nenhum fato digno de registro especial, mas que serve para avaliar o modo pelo qual o agente se tem conduzido na vida de relação. Exame esse que permitirá concluir se o crime é um simples episódio, resulta de má educação ou revela sua propensão para o mal.

Personalidade do agente: formada pelo conjunto dos dados externos e internos que moldam um feitio de agir do réu, instrumental que ele herdou ou adquiriu e com o qual responde às diversas situações que lhe são propostas na vida diária.

Motivos: são os fatores que animaram o agente a praticar o delito.

Circunstâncias: referem-se a todos os demais elementos que, como decorre da etimologia da palavra, cercaram o fato: de ordem externa (tempo, local, arma utilizada, etc.) ou interna (relações com a vítima, finalidade, etc.)

Consequências do crime: As consequências do crime podem variar substancialmente sem modificar a natureza do resultado, ainda que este integre o tipo.

Comportamento da vítima: A importância atribuída ao comportamento da vítima decorre dos estudos de vitimologia. É relevante para a apreciação de certos delitos, como os de lesão resultante de impulso provocado pelo agredido, os cometidos contra a honra, desde que não seja causa de não-aplicação da pena. 
Nas três sentenças analisadas as condições apontadas pelos juízes aos itens previstos no art. 59 do Código Penal foram proferidas conforme os dados no quadro abaixo:

Quadro 7 - Três fases da dosimetria da pena dos processos analisados

\begin{tabular}{|c|c|c|c|}
\hline & 1 Fase & 2 Fase & $3^{\text {a Fase }}$ \\
\hline Crime 1 & $\begin{array}{l}\text { Culpabilidade: Ciente do seu comportamento } \\
\text { Antecedentes: não possui bons antecedentes } \\
\text { Conduta social: não indicada } \\
\text { Personalidade: claramente voltada para a prática de } \\
\text { crimes desta espécie } \\
\text { Motivos: não indicados } \\
\text { Circunstâncias: Fraude e concurso de pessoas } \\
\text { Consequências: graves de vido ao valor inestimável } \\
\text { e por serem obras únicas } \\
\text { Comportamento da vítima: não indicado }\end{array}$ & Não há & Não há \\
\hline Crime 2 & $\begin{array}{l}\text { Culpabilidade: Não indicada. } \\
\text { Antecedentes: não podem ser considerados em } \\
\text { desfavor do réu } \\
\text { Conduta social: há parcos elementos de prova } \\
\text { acerca da } \\
\text { conduta social do réu, insuficientes para qualquer } \\
\text { juízo de valor. } \\
\text { Personalidade: Com efeito, o grau de premeditação } \\
\text { que se identifica na execução do crime é elevado e } \\
\text { revela a frieza e a convicção com que o réu dedicou- } \\
\text { se, sem hesitação, à prática do crime, a denotar } \\
\text { também traço de sua personalidade. } \\
\text { Motivos: ganância, busca por riqueza fácil } \\
\text { Circunstâncias: Fraude e concurso de pessoas } \\
\text { Consequências: gravíssimas, pois as peças são } \\
\text { raríssimas, muitas vezes superior às lesões a } \\
\text { patrimônios privados que ocorrem cotidianamente. } \\
\text { Comportamento da vítima: não indicado. }\end{array}$ & Não há & Não há \\
\hline Crime 3 & $\begin{array}{l}\text { Culpabilidade: Réu agiu com plena consciência do } \\
\text { resultado criminoso; } \\
\text { Antecedentes: Não há elementos suficientes nos } \\
\text { autos para aferi-los; } \\
\text { Conduta social: Não há elementos nos autos para } \\
\text { aferição segura, desajustamento de conduta social, } \\
\text { por não ser ato isolado, reprovabilidade elevada; } \\
\text { Personalidade: não há análise técnica } \\
\text { Motivos: busca do lucro fácil } \\
\text { Circunstâncias: Fraude e concurso de pessoas } \\
\text { Consequências: elevadas, prejudicando a história } \\
\text { da nação } \\
\text { Comportamento da vítima: não colaborou para os } \\
\text { acontecimentos }\end{array}$ & Não há & Não há \\
\hline
\end{tabular}

Fonte: Do autor 
A primeira fase corresponde à aplicação da pena-base conforme os itens apontados no art. 59, enquanto a segunda fase corresponde à avaliação de circunstâncias atenuantes ou agravantes e a terceira fase à análise de causas especiais de diminuição ou aumento da pena. O quadro acima corresponde ao que foi possível identificar nas três sentenças analisadas, pois estes dados não estão agrupados e alinhados dentro da explanação do juiz.

O quadro abaixo mostra a pena aplicada em cada uma das três sentenças:

Quadro 8 - Penas aplicadas nas três sentenças

\begin{tabular}{|l|l|l|l|l|l|}
\cline { 2 - 6 } \multicolumn{1}{l|}{} & Tempo & Multa & Valor dia-multa & $\begin{array}{l}\text { Regime } \\
\text { Inicial }\end{array}$ & $\begin{array}{l}\text { Pena } \\
\text { substitutiva }\end{array}$ \\
\hline Crime 1 & 5 anos & 60 dias-multa & 1 salário mínimo & Fechado & Não \\
\hline Crime 2 & 5 anos & 185 dias-multa & 1 salário mínimo & Fechado & Não \\
\hline Crime 3 & 4 anos & 120 dias-multa & $\begin{array}{l}1 / 30 \text { do salário } \\
\text { mínimo }\end{array}$ & Aberto & Sim* \\
\hline
\end{tabular}

Fonte: Do autor

Nota-se que duas das três penas aplicadas estavam exatamente na média entre o tempo mínimo e o máximo de reclusão permitido para este tipo de crime. A terceira pena foi aplicada mais próxima à média que ao mínimo de tempo de reclusão previsto no Código Penal para furto qualificado. Mas, nenhuma das penas ultrapassou a média e se aproximou da pena máxima. Quanto a multa, Aguiar Júnior (2001, p. 159-160) diz:

Para o cálculo da multa, a lei ordena [que] sejam consideradas, principalmente, as condições econômicas do réu. Isso permite [que] sejam levados em conta outros fatores, secundariamente. A necessidade de adequado ajustamento da pena recomenda seja ponderada também a gravidade da infração, em obediência ao princípio da proporcionalidade que deve existir entre um e outro. Por isso, conveniente que este dado interfira quando da fixação do número de dias a fim de manter o sistema geral do Código, em que a gravidade da infração determina a natureza e os limites mínimo e máximo da sanção. Fixado, segundo a gravidade do crime, o número de dias-multa, o valor de cada um deles ficará na dependência da avaliação das condições econômicas do condenado. 
Ou seja, para aplicação da quantidade de dias-multa e valor do dia-multa devem ser consideradas as condições econômicas do réu no momento da sentença. $\mathrm{Na}$ fixação do valor do dia-multa e da quantidade de dias-multa o juiz na sentença ao crime 1 disse que decide assim por constar "nos autos dados que atestam o razoável padrão de vida deste acusado, que ostentava veículos automotores de custo relativamente alto, bem como por ter acesso a ensino superior." O mesmo ocorre na sentença referente ao crime 2 , onde o juiz diz que assim decide "considerando que, apesar das poucas informações, o réu tinha negócio próprio e negociava peças em leilões de colecionadores de obras raras". A sentença do crime 3 , foi proferida anteriormente a do crime 2 , mas não consta nada sobre as condições econômicas do réu ao se estabelecer o valor e a quantidade de dias-multa.

Apenas na sentença do crime 2 a quantidade de dias-multa corresponde a média do mínimo e máximo permitido. Nas outras duas sentenças a quantidade é menor que a média. Na sentença referente ao crime 3 o valor do dia-multa corresponde ao mínimo previsto no art. $49 \S^{\circ}$ do Código Penal. Nas demais sentenças o valor não atinge nem a metade do máximo previsto neste mesmo artigo. Vale ressaltar que este valor não é uma recompensação baseada no valor das obras subtraídas.

O motivo para o réu não ter como agravante em nenhuma de suas sentenças o fator de ser reincidente, acontece porque nenhum dos processos se encontrava transitado em julgado, conforme determina o art. 63 do Código Penal; ou seja, como ainda cabiam recursos aos processos não podia usar a reincidência como agravante do crime. Portanto, como estes casos se encontram agora transitados em julgado, as próximas sentenças proferidas nos processos restantes poderão agravar a pena.

Não foi possível identificar qualquer dispositivo para cálculo da média das penas aplicadas em sentenças de furto qualificado, ainda mais envolvendo a subtração de objetos de valor histórico-cultural. No entanto, é possível dizer que as penas aplicadas neste caso foram altas para a tipicidade do crime, pois foi aprovado na Comissão de Constituição e Justiça e de Cidadania (CCJC) da Câmara dos Deputados o Anteprojeto 03/2012, que entre outras coisas, propõe a alteração da pena aplicada no furto qualificado, de um a 5 anos de reclusão. Este anteprojeto, se 
transformou no Projeto de Lei 4.894 de 2012, que também prevê o aumento da pena em $1 / 3$ caso a coisa furtada seja de bem público (NOBRE, 2012). Por exemplo, se as duas penas que foram aplicadas na média na pena atual do Código Penal (2 a 8 anos) fossem aplicadas ao modelo proposto, a pena nova seria de 3 anos, sendo acrescida de $1 / 3$ por se tratarem de obras furtadas de bem público de modo que a pena final seria 4 anos. Neste contexto, as penas de 5 anos aplicadas correspondem a pena máxima prevista no anteprojeto.

\subsection{Terceira etapa - Entrevistas com especialistas, delegado da Polícia Federal e representantes do Iphan}

Nesta etapa foram feitas entrevistas semiestruturadas, com questionário prédefinido (Apêndice C, D e E), com o Entrevistado A, Chefe da Coleção de obras raras da Biblioteca Nacional; Entrevistado B, Diretora do Arquivo Geral da Cidade do Rio de Janeiro; Entrevistado C, ex-chefe do Setor de Iconografia da Bibioteca Nacional; Entrevistado D, delegado da Delemaph/RJ; Entrevistados E e F, Coordenador-Geral de Patrimônio Natural e técnica em artes do Iphan, respectivamente.

As entrevistas foram feitas com três segmentos diferentes ligados ao universo do combate ao roubo ou furto de livros raros. Houve entrevista com especialistas ligados à guarda deste tipo de acervo (Entrevistados A, B e C), com um Delegado da Polícia Federal - responsável pelas investigações sobre este tipo de crime, principalmente aqueles de esfera Federal ou de bens tombados (Entrevistado D) - e com membros do Iphan, que têm entre suas funções a de fiscalizar o comércio do patrimônio histórico, universo em que está inserido o livro raro, e de estabelecer diretrizes de salvaguarda destes bens (Entrevistados E e F). Portanto, foram elaborados três roteiros distintos a esses três segmentos (Apêndices C, D e E). 


\subsubsection{Análise das entrevistas}

Quanto às entrevistas com os especialistas guardiões de livros raros, nota-se que houve consenso em várias questões e que a divergência mais acentuada está no uso ou não de marcas de propriedade definitivas nas obras. Os três entrevistados concordam que uma das principais ferramentas de segurança é o comprometimento dos funcionários, que estes se sintam e hajam como responsáveis pela guarda dos livros raros. Esta condição é colocada explicitamente pelos Entrevistados A e C, que acreditam que a participação efetiva de todos os funcionários na segurança do acervo antecede e é mais importante que a segurança física e eletrônica das obras. Quanto ao comprometimento profissional, o Entrevistado B levanta a questão sobre a alta evasão e rotatividade de funcionários no serviço público, que prejudica as atividades que requerem uma ação continuada.

A capacitação dos funcionários e mais especificamente do bibliotecário é colocada como ferramenta importante na segurança contra roubo e furto de livros raros, tanto pelo Entrevistado A quanto pelo Entrevistado C. O Entrevistado A diz que a geração de bibliotecários que está sendo formada mais recentemente está se preocupando mais com a segurança contra roubo e furto; diz também que devem aumentar as discussões sobre o assunto nos cursos de Biblioteconomia e em eventos nacionais e internacionais. Já o Entrevistado $C$ fala que o bibliotecário deve se capacitar quanto ao mercado de antiguidades, como os leilões, para saber como funcionam as transações e, com isso, ser possível identificar obras de origem ilícita. Esta condição também permite trabalhar em conjunto com a polícia no combate à comercialização ilegal de livros raros e bens culturais. Estas alegações vão ao encontro da revisão de literatura deste trabalho que aponta a formação profissional dos responsáveis pelas coleções de livros raros como fator essencial na segurança deste tipo de acervo. O principal dispositivo de segurança nas instituições é o recurso humano, onde um funcionário engajado, motivado e preparado irá estabelecer rotinas e procedimentos de segurança e obedecê-los, pois tem consciência da importância do acervo que cuida. Todos os procedimentos e equipamentos adotados em um programa de segurança, sejam físicos ou 
eletrônicos, serão ineficazes caso aquele que cuida do seu funcionamento adequado resolva agir contra a instituição.

Apesar dos crimes de roubo e furto de livros raros no Brasil, analisados anteriormente, não apresentarem suspeita concreta sobre a participação de funcionários na ação criminosa, nos casos apresentados no tópico 2.6 nesse trabalho é possível ver que em muitos crimes, aqueles que deveriam tomar conta do acervo são aqueles que se aproveitam da proximidade a ele para atacá-lo. Portanto, é necessário que as instituições tenham preocupação elevada com a contratação de funcionários e estagiários que irão atuar diretamente ou indiretamente com acervos raros. É preciso intensificar os métodos de controle de acesso ao acervo, com vigilância ininterrupta nas áreas de guarda, processamento técnico, restauração e exposição. Todas as ações de segurança devem ser submetidas a todos os escalões da instituição, não havendo exceções, pois como foi possível ver, na Biblioteca Girolamini, o próprio diretor da instituição foi quem atuou nos crimes.

Além dos dispositivos eletrônicos e as barreiras físicas na segurança contra roubo e furto, tanto o Entrevistado A quanto o Entrevistado B apontam o conhecimento do acervo como essencial para praticar uma boa segurança. $O$ Entrevistado $A$ ainda fala sobre a descrição bibliográfica mínima na chegada do acervo e, posteriormente, uma descrição bibliográfica minuciosa como ferramentas primordiais à segurança contra roubo e furto, pois essas ações evidenciam a quem pertence a obra. Essas características foram abordadas neste trabalho na revisão de literatura nas figuras da análise bibliológica, da fotobibliografia e da pesquisa bibliográfica. O conhecimento do acervo faz com que seja melhor aplicadas as estruturas de segurança, havendo separação de obras que possivelmente seria alvo prioritário dos criminosos, de exemplares menos visados, sendo colocada sobre maior proteção. Também ajuda a conscientizar os funcionários sobre a importância do acervo e o impacto que causaria sua perda. Conhecer detalhadamente os livros raros pode ajudar na identificação rápida de um crime, podendo, por exemplo, o funcionário perceber a ausência de um exemplar que sempre esteve em determinado lugar e que não se encontra mais. 
Os três entrevistados também concordam em suas alegações no que tange à mudança cultural no usuário de um modo geral, para que o mesmo entenda que o acervo também é um patrimônio seu e que a biblioteca é de uso coletivo. Esta é uma das maiores dificuldades que as instituições enfrentam quanto à segurança contra roubo e furto segundo o Entrevistado $A$. Já o Entrevistado B diz que o cidadão tem que aprender que o patrimônio é seu, para entender o impacto causado pela perda. Para o Entrevistado C, mudar a mentalidade das pessoas também é uma ferramenta de segurança no caso de livros raros. Portanto, para o Entrevistado A e para o Entrevistado $\mathrm{C}$ o roubo ou furto de um livro raro é uma perda completa para o patrimônio cultural, assim como para a própria profissão do bibliotecário e mesmo para a construção do conhecimento científico.

Para os três entrevistados não há verba específica para qualquer investimento nas instituições guardiãs de livros raros e, consequentemente, não há recursos financeiros específicos para a segurança contra roubo e furto. A criação e abrangência de um programa de segurança contra roubo e furto é dependente das possibilidades financeiras da instituição, que vai influir na existência de equipe de segurança, como também na quantidade de pessoas que fará parte dela, na qualidade e quantidade de equipamentos eletrônicos de vigilância e alarme, no investimento em capacitação dos funcionários, entre outros aspectos. Portanto, a conscientização do usuário citada anteriormente irá refletir numa mudança cultural a longo prazo, de modo a aumentar a quantidade de cidadãos responsáveis e preocupados com a preservação de bens culturais, que refletirá na ampliação de gestores públicos e privados também preocupados com essa temática. Consequentemente, o aumento da conscientização e preocupação com o patrimônio histórico cultural faz com que se aumente todos os meios, inclusive financeiros, para a gestão adequada dos acervos históricos e culturais.

Cada entrevistado aponta uma situação diferente quando questionados sobre as maiores dificuldades para a recuperação das obras furtadas ou roubadas. Para o Entrevistado A falta comunicação entre os bibliotecários quando ocorre um crime como esse, de modo a divulgar para a classe que houve o crime, quais as obras levadas e as características da ação dos criminosos. O Entrevistado B diz que na 
Polícia Federal há uma rotatividade muito grande de policiais, impossibilitando a especialização dos mesmos no combate a estes crimes. O Entrevistado $C$, no entanto, acredita que falta centralização na apuração e controle dos dados fornecidos pelas instituições e que este trabalho deveria ser exercido pelo Iphan. Contudo, na entrevista feita com os membros do Iphan os mesmos informaram que as obras cujo controle thes cabe são as que pertencem aos bens tombados por esta instituição. Foi discutido nessa entrevista, por exemplo, a não inclusão de uma obra furtada do IGHB no Banco de Dados de Bens Culturais Procurados que o Iphan mantém, tendo como resposta principal o não tombamento e não unicidade do item; mesmo assim o Iphan lançou nota em seu site sobre o crime ocorrido e o desaparecimento desta obra.

Todos os entrevistados levantam considerações que transparecem uma preocupação em comum, que é a falta de integração de dados entre os agentes envolvidos na segurança do patrimônio histórico e cultural. O Entrevistado $F$ fala sobre uma ferramenta desenvolvida pelo Iphan que caminha na direção de integrar de modo mais amplo as diversas informações sobre a preservação dos acervos, que é o Sistema Integrado de Conhecimento e Gestão (SICG). Portanto, com o desenvolvimento dessa ferramenta, deve-se haver também a criação de legislação que obrigue as instituições a se cadastrarem e emitirem seus dados de gestão periodicamente. Pois, como visto na fala dos Entrevistados $E$ e $F$, não há, por exemplo, uma previsão legal sobre punição para aquele que não se cadastrar no Cadastro Nacional dos Negociantes de Antiguidades e Obras de Arte (Cnart).

Como dito, os entrevistados divergiram quanto ao uso de marcas de propriedade definitivas nos livros raros. Os Entrevistados B e C são a favor do uso destas marcas, pois consideram que é dessa forma que se comprova que a obra é de determinada instituição em caso de recuperação da mesma, e que esta prática diminui $O$ interesse em subtrair as obras, pois teriam que interferir no item para remoção da marca. O Entrevistado $A$ posicionou-se contra, pois para ela não existem marcas definitivas, porque todas podem ser removidas e ainda alteram a condição original da obra, diminuindo o seu valor. Para esta entrevistada, as pessoas que roubam ou furtam livros raros fazem parte de uma quadrilha em que geralmente há restauradores envolvidos para a retirada dos carimbos. 
Para Gauz (1994; 2004) deve-se usar marcas de propriedade, pois a premissa é que estes livros não sairão das bibliotecas de custódia. Esse procedimento também é recomendado no Apêndice I do ACRL/RBMS Guidelines... (2009), que reconhece que as marcações são alterações no documento, mas que defende o uso delas, principalmente para a identificação de propriedade em caso de roubo ou furto e posterior recuperação das obras e devolução das mesmas à instituição de origem. Brown e Patkus ([20--?]) dizem que é preciso considerar o uso de marcação, mas reconhecem que essa pode não ser uma medida apropriada para materiais de valor histórico. Nesse trabalho não é recriminado o uso de marca de propriedade nas instituições, por reconhecer que há alguns casos em que ela pode ajudar a identificar materiais provenientes de roubo e furto. No entanto, o presente trabalho não recomenda a marcação dos livros raros, por adotar os mesmos argumentos do Entrevistado A. Nos crimes analisados, como já visto, foi possível identificar a atuação de uma quadrilha especializada em roubos e furtos de livros raros, onde aquele que é considerado o mentor desse grupo criminoso foi aluno de Biblioteconomia, estagiário de biblioteca, mercador de livros raros e é conhecedor de restauração. Também foi apontado como suspeito junto à quadrilha um comerciante de antiguidades que confessou ter feito processos de remoção de marcas de propriedade em obras compradas por ele. Nesse contexto, onde os criminosos são especializados no comércio de antiguidades e nos processos biblioteconômicos, e como a marca de propriedade não é usada sobre a informação textual, ela pode ser removida desfazendo o seu propósito e ocasionando perda ou dano ao suporte original. Outro fator a ser considerado para a não adoção da marca de propriedade é que esta interfere na integridade e originalidade da obra, acarretando perda patrimonial ao objeto livro. Foi possível observar na análise dos roubos e furtos de livros raros que a marca de propriedade não exerceu um efeito dissuasor nos criminosos, pois, foi grande o número de obras marcadas que foram subtraídas das instituições analisadas. Portanto, a recomendação nesse trabalho é que não se use marcas de propriedade nos livros raros. Caso essa recomendação seja seguida pelas instituições, exige-se delas maior rigor em seu plano de segurança, para que aumentem ainda mais as dificuldades de roubo e furto, com vigilância atenta e constante sobre as obras, os usuários e os funcionários. Esse se torna mais um 
motivo para que se evite o roubo e furto de livros raros, pois, caso as obras sejam subtraídas sua recuperação pode estar comprometida pela ausência de marcação. Mesmo assim, a análise bibliológica pode trazer meios de individualização dos exemplares e consequentemente determinar a propriedade de uma obra por meio do levantamento minucioso dos detalhes de cada livro. Portanto, as instituições devem fazer uma rigorosa análise bibliológica, que permita identificar a obra como pertencente a determinada instituição no caso de recuperação de um exemplar que tenha sido roubado ou furtado. As preocupações sobre o uso de marcas de propriedade aqui listadas provavelmente são compartilhadas por 19 (23,17\%) instituições (de 82) que responderam não fazer uso delas na pesquisa sobre prevenção situacional.

Na Biblioteca Nacional não houve caso específico de roubo ou furto de livros raros recentemente, mas o Entrevistado A comentou a situação do Setor de Iconografia, que tem de ser lacrado na saída dos funcionários, sendo reaberto, rompendo o lacre, apenas no outro dia, no início do expediente. No Arquivo Geral da Cidade do Rio de Janeiro, onde o Entrevistado B trabalha, a dificuldade aparece na falta de controle da coleção, que estava se iniciando no momento em que ocorreram os furtos; ele considerou que não houve uma perícia muito detalhada no local para identificação de digitais e pistas do gênero. No caso do Setor de Iconografia da Biblioteca Nacional, local onde o Entrevistado C trabalha, sua percepção sobre as dificuldades de apuração do crime lá ocorrido foi de que a Polícia Federal está muito subordinada ao MPF, não tendo muita autonomia para pedidos diretos aos juízes de processos de buscas e apreensões e prisões preventivas dos suspeitos. Ele também fala a respeito da rotatividade de policiais, que, segundo sua opinião, faz com que estes profissionais não tenham conhecimento do mercado de antiguidades e que sejam inexperientes na apuração deste tipo de crime.

$\mathrm{Na}$ entrevista com o Entrevistado D, delegado da Delegacia de Meio Ambiente e Patrimônio Histórico da Polícia Federal do Rio de Janeiro, é possível identificar um papel atuante desta polícia principalmente na apuração dos crimes, não sendo muito comum sua atuação na prevenção aos mesmos. Entre as dificuldades apresentadas está a alta rotatividade de policiais, como também foi 
apontado pelos especialistas entrevistados. O delegado também apontou como problema a estrutura da Delemaph, que tem que atuar tanto nos crimes contra o meio ambiente quanto nos crimes ao patrimônio histórico, pois ambos os campos são muito vastos no Brasil. Este aspecto também foi levantado pelo Entrevistado B. Portanto, nota-se necessário que haja maior expertise por parte da Polícia Federal na apuração destes crimes, pois nos crimes analisados é possível notar uma ação continuada dos criminosos. A rotatividade de policiais e delegados impede que sejam ampliadas as medidas de colaboração entre a PF e as instituições guardiãs de bens culturais a longo prazo.

Uma dificuldade na apuração destes crimes, segundo o Entrevistado D, é a demora em se identificar o ocorrido, pois alguns só são descobertos pela instituição após a devolução de obras apreendidas nas operações policiais. Assim como, quando identificada uma ação criminosa em uma instituição, a comunicação do fato é demorada devido à burocracia envolvida. $O$ delegado também diz que algumas instituições deixam de exercer atitudes mínimas que poderiam prevenir a ocorrência ou agilizar a apuração criminal. Ele cita entre essas ações a disposição ideal de câmeras nos lugares onde estão as obras, a guarda das gravações de imagem das câmeras por longo tempo e a anotação do Cadastro de Pessoa Física (CPF) ao invés do RG, por ser um banco de dados nacional. Essa análise remete a responsabilidade às instituições guardiãs que devem estabelecer um plano de segurança capaz de identificar imediatamente ou o mais rápido possível o desaparecimento de alguma obra, reforçando a vigilância e fazendo um controle rigoroso do acervo, por meio de inventário. Os motivos para essa demora na identificação de casos de roubo e furto são identificados na pesquisa sobre prevenção situacional onde a maioria das instituições não possuem instalados equipamentos eletrônicos de vigilância, contenção e alarme, ou mesmo quando possuem, elas não apresentam tecnologia adequada ou não são monitorados da forma correta. Como exemplo da não utilização ou uso inadequado dos equipamentos eletrônicos, está a baixa adoção de câmeras nas instituições, que é usada em menos da metade delas, em 38 (46,34\%), além do fato de que onde há o uso das câmeras, as mesmas não possuem visão noturna em 17 (44,74\%) instituições, assim como em apenas $12(31,38 \%)$ instituições há monitoramento da 
câmeras por 24 horas. Essa situação é agravada ainda pela falta de controle do acervo, pois apesar de $66(80,49 \%)$ das instituições pesquisadas já terem feito inventário, quase metade dessas, 31 (46,97\%) não fazem o inventário periodicamente.

O delegado diz também que é importante para a segurança contra roubo e furto a atenção acentuada de um vigilante, que pode evitar, por exemplo, a aglomeração de pessoas ao redor de uma mesa de consulta, que funcionaria como barreira para a visão dos funcionários sobre as ações exercidas naquele local. As alegações do Entrevistado D vão ao encontro da abordagem utilizada na revisão de literatura deste trabalho, apontando a importância de um plano de segurança com rotinas bem estabelecidas, treinamento continuado do pessoal e uso consciente das ferramentas eletrônicas. O discurso do delegado também traça paralelo com os resultados encontrados na pesquisa sobre prevenção situacional nas instituições guardiãs de livros raros, que deixam em alguns casos de adotar procedimentos simples e que podem ser o diferencial quanto à segurança contra roubo e furto. Como por exemplo, a adoção de um plano de controle de chaves, que não é exercido em 21 (25,61\%) das 82 instituições pesquisadas.

O Iphan possui o Cadastro Nacional de Negociantes de Antiguidades e Obras de Arte (Cnart), onde todo comerciante de antiguidades ou leiloeiro que vá comercializar alguma peça histórica deve se cadastrar. Os representantes do Iphan entrevistados disseram que o instituto atua principalmente nos leilões informados por este cadastro e que pode atuar também em casos de denúncias; mas reconhecem que o universo do comércio de livros raros e bens culturais é muito grande, principalmente ser forem levados em consideração os e-commerces. Portanto, não é possível fazer uma fiscalização efetiva em todos esses meios de negociação, assim como não há pessoal suficiente para esta atividade.

O Iphan faz campanhas de conscientização em eventos de comercialização de bens culturais, para que os comerciantes se inscrevam no Cnart. Contudo, não há uma previsão legal da aplicação de multa, por exemplo, caso um comerciante não se inscreva. Também não há um canal específico para denúncia de leilões não comunicados ao Iphan. Os entrevistados ressaltam que esta ação de combate ao 
comércio ilegal e recuperação de bens deve ser um trabalho em conjunto entre o Iphan, o MPF e a Polícia Federal.

O tombamento de coleções bibliográficas, conforme mostram Murguia e Yassuda (2007), não é algo comum, como é possível ver no Guia de Bens Tombados pelo Iphan, que traz tudo tombado até 2012. Os entrevistados dizem que isso ocorre provavelmente por existirem outros meios de proteção a esses acervos, além do tombamento, e que este é realizado em obras únicas, o que não acontece com os livros que possuem muitos exemplares. Portanto, o não tombamento de alguns acervos bibliográficos não permite sua inclusão, caso seja roubado ou furtado, no Banco de Dados de Consulta a Bens Culturais Procurados mantido pelo Iphan. Em e-mail posterior à entrevista, para complementação desta, os Entrevistados $\mathrm{E}$ e $\mathrm{F}$ trazem notícias de alguns acervos bibliográficos tombados e explicam um pouco mais sobre o tombamento de livros:

1996 - Bem: Coleção Mário de Andrade do IEB/USP, produto de quatro subcoleções distintas assim caracterizadas: 1) Sub-coleção de Artes Visuais; 2) Subcoleção de Arte Religiosa e Popular; 3) Sub-coleção da Revolução de 1932; 4) Subcoleção Bibliográfica (São Paulo/SP). Inscrito nos Livros do Tombo de Belas Artes, Histórico e Arquitetônico/Etnográfico e Paisagístico.

1999 - Bem: Igreja da Ordem Terceira do Carmo, restrita às frontaria, nave, capelamor, sacristia, biblioteca, sala de reuniões, obra de talha, imaginária e pinturas aí localizadas, especialmente a obra pictórica do Padre Jesuíno do Monte Carmelo, incluindo o conjunto de 18 (dezoito) painéis provenientes do antigo Recolhimento de Santa Teresa expostos no corredor lateral da igreja, assim como o acervo de bens móveis e o arquivo da confraria (São Paulo/SP). Inscrito nos Livros do Tombo de Belas Artes e Histórico.

1999 - Bem: Torah constituída por nove rolos em pergaminho, que integra o acervo do Museu Nacional da Universidade Federal do Rio de Janeiro sob a classificação de "Manuscritos IVRIIM" (Rio de Janeiro/RJ). Inscrito no Livro do Tombo Histórico. 
2003 - Bem: Sítio Roberto Burle Marx e sua coleção museológica e bibliográfica (Rio de Janeiro/RJ). Inscrito nos Livros do Tombo de Belas Artes e Arquitetônico/Etnográfico e Paisagístico.

Os procedimentos para o processo de tombamento estão estabelecidos pela Portaria do Iphan oㅜ 11/1986. Nessa normativa se pode identificar as etapas de solicitação, de instrução técnica e de aprovação pelo Conselho Consultivo do Patrimônio Cultural.

Reiteramos, após a entrevista, que o tombamento não é um instrumento que deva ser pensado como substituto da ineficácia na gestão dos bens culturais. No caso dos acervos de obras raras, muitas vezes os exemplares, embora valiosos em si ou pela constituição da biblioteca de origem, encontram-se repetidos em outros acervos, ou mesmo não possuem os valores de representatividade para a memória e a cultura nacional na perspectiva do órgão federal de patrimônio cultural. 


\section{Conclusão}

Diante do contexto apresentado pela Teoria do Crime, onde o criminoso age racionalmente levando em consideração uma relação de custo $X$ benefício sobre sua ação, é possível dizer que, no Brasil, no universo dos roubos e furtos de livros raros os benefícios são altos e os custos pequenos. Neste trabalho foi levantada a hipótese de que o modelo atual de dissuasão (índice de prisão, índice de condenação, severidade da pena e prevenção situacional) referente aos crimes contra o patrimônio cultural age como facilitador do roubo ou furto de livros raros. Esta hipótese é comprovada e a análise que permite sua comprovação mostra que há falhas em todos os aspectos da dissuasão contra o roubo e furto de livros raros.

Os livros raros são parte integrante do patrimônio histórico, reconhecida sua importância por lei. São objetos informacionais para além de seu conteúdo textual, mas também pela matéria-prima usada, as técnicas artesanais, a adoção de gravuras como ilustração, entre outros aspectos. Por isso são itens detentores de memória individual e coletiva, já que as técnicas e matérias-primas são aquelas que estão disponíveis em determinado tempo-espaço, assim como aquele que exerce esse ofício trabalha com essas limitações, às vezes propondo melhorias dentro do universo sociocultural em que está inserido. Esta importância histórico-cultural do livro raro faz com que ele atinja elevados valores venais para aqueles que o admiram, desejam e colecionam, enquanto, a possibilidade de ganho financeiro atrai a atenção de criminosos que querem lucrar a partir da subtração destas obras.

O objetivo geral foi alcançado, já que o mesmo correspondia a investigar o roubo ou furto de livros raros pela perspectiva da Teoria da Dissuasão no contexto da Economia do Crime. Foram averiguados 15 crimes em que houve a subtração de ao menos um livro raro. Os dados sobre eles foram levantados por meio do contato com as instituições furtadas ou roubadas, nas notícias em jornal e na internet sobre os crimes, em contatos com algumas delegacias da Polícia Civil e em processos judiciais localizados na Justiça Federal do Rio de Janeiro e no Tribunal de Justiça do Paraná. 
Em relação aos objetivos específicos, foi possível atendê-los em sua maioria. O primeiro objetivo específico consistia em identificar e analisar os processos e a estrutura de segurança existentes nas instituições guardiãs de livros raros. Para alcançar este objetivo foi enviado questionário às 135 instituições cadastradas no Planor, obtendo $82(60,74 \%)$ respondentes.

A análise dos crimes contra as coleções que possuem livros raros, da prevenção situacional nas instituições guardiãs desse tipo de acervo e das entrevistas com especialistas na gestão de livros raros mostra que as obras não estão protegidas em seu ambiente de guarda. Condições mínimas de segurança não são empregadas na maioria das instituições. De 35 itens de segurança que englobam controle de chaves, uso de dispositivos eletrônicos, adoção de um plano de segurança, controle do acervo e formação do profissional responsável pela coleção, a maioria das respondentes disse não usar sequer metade dos itens questionados. Isto também reflete a falta de verba e pessoal para a criação de programas de segurança, emprego de equipamentos de segurança e manutenção periódica destes.

O segundo objetivo específico era listar e analisar os casos de roubos de livros raros no Brasil. Este objetivo foi alcançado plenamente com a averiguação dos crimes contra o Instituto de Pesquisas Jardim Botânico e Palácio do Itamaraty, ambos localizados no Rio de Janeiro, com incidência de furtos no ano de 2003. Em 2004 houve os casos do Museu Histórico Nacional e Museu Nacional da UFRJ, também no Rio de Janeiro, e do Centro de Ciências, Letras e Artes, na cidade de Campinas, estado de São Paulo. O ano de 2006 foi quando mais houve casos de furto de livros raros, com os casos da Escola de Belas Artes da UFRJ, do Museu Chácara do Céu e do Arquivo Geral da Cidade, todos no Rio de Janeiro; assim como os casos da Biblioteca Mário de Andrade, em São Paulo, e da Biblioteca Pública do Paraná, em Curitiba. No ano de 2007 aconteceram dois furtos, um no Rio de Janeiro, na Fundação Oswaldo Cruz, e outro no Instituto Geográfico e Histórico da Bahia, em Salvador. No Museu Paraense Emílio Goeldi, em Belém, no Pará, houve um furto em 2008, e no Instituto de Botânica, em São Paulo, houve um roubo em 2012. O Centro de Ciências, Letras e Artes é a única instituição analisada em que 
aconteceram dois crimes relacionados a livros raros, sendo um furto em 2004 e um roubo em 2013.

Nos 15 casos analisados, foi possível estabelecer a quantidade de itens roubados ou furtados em 496 exemplares completos, assim como o total de obras recuperadas, que é de apenas 209 (42,13\%) exemplares completos. O número de obras desaparecidas pode ser maior, pois, no caso do CCLA em 2004, foi feito boletim de ocorrência apenas com a quantidade de obras que a polícia havia informado sobre a recuperação. Foi citado neste caso que o acervo não estava totalmente controlado; ou seja, pode haver mais obras furtadas que não foram identificadas pela instituição. Caso semelhante aconteceu no Instituto de Botânica de São Paulo em que as notícias sobre o crime apontavam 15 exemplares roubados e os dados enviados pela Polícia Civil indicaram a recuperação de 22 exemplares. A exemplo deste caso, outros podem ter ocorrido em que a instituição não conseguiu estabelecer com exatidão quantas obras foram levadas ou mesmo terem omitido a quantidade exata. Também é possível que algumas instituições tenham atribuído uma quantidade de obras desaparecidas que não correspondam a um crime em específico, mas a um processo longo de subtração de obras por diversas formas e pessoas. Estes dados atendem parcialmente ao terceiro objetivo específico, que visava a identificar e analisar o índice de recuperação dos livros raros roubados.

Analisar a legislação pertinente ao contexto de livros raros e a consequente aplicação da lei nos casos de roubo e furto dessas obras é o quarto objetivo específico deste trabalho. Este objetivo foi atendido plenamente, na observação da legislação brasileira. No que tange ao roubo e furto de livros raros, enquadram-se na legislação concernente ao patrimônio de um modo geral; ou seja, para a legislação não há diferença com relação ao objeto subtraído, com exceção de veículo automotor, em que há acréscimo da pena caso este seja levado a outro estado ou para o exterior. Portanto, não há uma obrigatoriedade de majoração da pena pelo juiz por se tratar de um livro raro, mesmo que este seja único; mas se pode levar este fator em consideração ao estipular a amplitude da pena prevista em lei.

A única lei brasileira específica aplicada aos livros raros é a de $n^{0} 5.471$ de 1968. Neste dispositivo legal, livros publicados no Brasil e sobre o Brasil até o século 
XIX são impedidos de ser exportados. No entanto, não é prevista uma pena específica para este caso, de modo que este crime se enquadraria em contrabando, sem diferenciação da pena pelo tipo de objeto, que não é previsto na lei. A Instrução Normativa 01 , do Iphan, cita o livro raro explicitamente ao colocá-lo como objeto obrigatório de comunicação a este órgão sobre sua comercialização. O tombamento pelo Iphan poderia ser outra forma de proteção ao livro raro, pois prevê que a comercialização e a restauração do bem tombado devem ser previamente informadas e autorizadas pelo órgão. No entanto, foi visto neste trabalho que não são comuns os processos de tombamento de conjuntos bibliográficos. Fora os tombamentos que já são previstos em lei, como os acervos bibliográficos de igrejas tombadas individualmente e de documentos que contenham reminiscência quilombola, não é muito comum o uso desta ferramenta de proteção aos livros raros. Como explicado pelos funcionários do Iphan entrevistados, isso ocorre porque livros possuem mais de um exemplar.

Viapiana (2006) mostra que é maior o rigor penal quanto maior for a rejeição social a determinado tipo de crime. Portanto, é possível dizer, por meio da avaliação da legislação brasileira, que os crimes contra os bens culturais e, consequentemente, ao livro raro não são considerados muito graves pela sociedade, pois o único dispositivo no Código Penal que qualifica o crime por ter sido cometido contra um bem de valor artístico, arqueológico ou histórico é o crime de dano. Mesmo neste caso, o bem precisa ser tombado, caso que não ocorre com muita frequência aos livros raros, como visto anteriormente. $O$ dano a qualquer bem público, seja ele pertencente ou não ao patrimônio histórico nacional, tem a previsão legal de uma pena máxima que seja maior que uma pena ao dano a um bem tombado.

Como verificado, existe um Projeto de Lei que propõe a diminuição penal para furto simples, furto qualificado e roubo, mas este prevê o aumento da pena caso os itens subtraídos neste crime seja praticado aos bens públicos; ou seja, não há qualquer previsão legal para acréscimo de pena caso uma obra do patrimônio histórico seja roubada ou furtada por sua importância nacional. Mesmo que haja previsão de acréscimo na pena em caso de dano às obras pertencentes ao 
patrimônio público, não acontece o mesmo na legislação atual para furto, furto qualificado e roubo. Também não há previsão para majoração da pena em casos de crimes ao patrimônio histórico privado. No caso de livros, vê-se que, com frequência, os livros raros pertencentes a particulares se tornam bens públicos posteriormente, como aconteceu, por exemplo, com a coleção do notório colecionador José Mindlin, que teve suas obras integradas ao acervo da Universidade de São Paulo (USP).

Foi possível, na revisão de literatura, estabelecer relação entre a Economia do Crime e o roubo e furto de livros raros, que corresponde ao quinto objetivo específico, pois os livros apresentam valor considerável de mercado, de modo que há ganho financeiro em sua subtração. Portanto, nos casos de roubo e furto de livros raros, este trabalho pressupõe que os criminosos agem de forma consciente e planejam a ação racionalmente, levando em consideração uma relação de custo $X$ benefício, como previsto na Economia do Crime.

O sexto e último objetivo específico previa identificar o índice de prisão e condenação dos autores de roubos de livros raros. Este objetivo foi atendido parcialmente, já que não foi possível estabelecer com exatidão os índices de prisão e condenação, pois o envolvimento de uma mesma quadrilha na ação da maioria dos crimes impede esta análise. Muitos dos envolvidos são indiciados em mais de um processo criminal, tendo sua prisão preventiva decretada em todos eles. Nem todas as prisões são passíveis de averiguação nos processos analisados, de modo que se dificulta o estabelecimento de um índice preciso sobre a quantidade de prisões efetuadas. No entanto, a participação de uma quadrilha em pelo menos 11 dos 15 crimes analisados mostra que a percepção dos custos pelos criminosos não são elevadas, assim como devem ser altos os benefícios, pois há o envolvimento de ao menos 15 pessoas neste grupo criminoso. Portanto, como é possível ver na análise dos crimes, as ações são premeditadas, com uma atuação padrão, usando dados falsos de identificação pessoal, estudo prévio da instituição e dos funcionários, estudo in loco para reconhecimento do local e das obras, como também visitas contínuas para a subtração dos itens.

É possível verificar também uma mudança comportamental da quadrilha, que nos crimes mais recentes emprega a violência, sendo os crimes realizados à mão 
armada. Nota-se também que há um mercado que possibilita a circulação destas obras, pois nos processos judiciais são citadas devoluções de obras por comerciantes, colocação de exemplares em leilões e o alto conhecimento do mercado pelos criminosos.

O índice de condenação é de 100\% dos envolvidos nas ações em que houve roubo ou furto de livros raros, naqueles processos que já possuem sentença. A pena foi considerada alta em comparação ao Projeto de Lei 4.894 de 2012 que propõe a redução da pena para furto qualificado. No entanto, nenhuma sentença proferida, segundo a legislação atual, ultrapassou a média penal prevista. Nos processos analisados é possível ver também que a imputação dos crimes aos réus acontece mediante a identificação de funcionários das instituições lesadas; ou seja, em nenhum momento é citado o reconhecimento das práticas criminosas e dos suspeitos por gravações de câmeras de vigilância. O uso de câmeras provavelmente serviria de ajuda na identificação, por exemplo, da participação de funcionários nos atos criminosos, como foi suspeitado em alguns casos devido à grande quantidade de obras e do tamanho dos exemplares levados. Também, em alguns casos, a câmera poderia inibir o furto de obras, pois nestes tipos de delitos os criminosos tentam agir de modo que não sejam apanhados e identificados posteriormente.

Apesar de não ser possível apontar índices precisos de condenação, pena e prisão, mesmo que o fosse, não existem parâmetros nacionais para comparação. Isto demonstra a ausência de ações de inteligência no combate a este tipo de crime, principalmente na averiguação policial. Esta condição é agravada pela estruturação da Polícia Federal, uma das instituições mais atuantes no combate a este tipo de crime, onde há uma rotatividade grande de agentes e delegados, evitando que se crie uma necessária expertise neste tipo de ocorrência. Esta especialização também é prejudicada pela amplitude das atribuições da Delemaph, que também é encarregada de cuidar dos crimes ao meio ambiente brasileiro.

O rigor penal foi considerado alto e o índice de condenação até o momento é de $100 \%$ dos processos em que há sentença proferida. No entanto, não é possível dizer que o rigor penal age de forma a dissuadir os criminosos de cometer novos crimes, pois, pelo que foi constatado, membros da quadrilha especializada em furto 
e roubo de livros raros continuam a praticar os delitos mesmo depois de condenados e presos, e retornaram à atividade criminosa após o cumprimento parcial da pena.

Diante de todas as condições analisadas, é possível verificar que as ferramentas de dissuasão, rigor penal, eficácia policial e prevenção situacional, no contexto de livros raros, não intimidam os criminosos que desejam obter lucro a partir do roubo e furto destes exemplares. As instituições não possuem condições de segurança suficiente para dificultar a ação dos criminosos. Também não identificam os crimes no momento em que acontecem, impossibilitando uma atuação rápida das autoridades policiais; assim como a legislação não tem dispositivos penais suficientes para a aplicação de penas maiores, como também não há alta reprovação social a este tipo de crime. $O$ índice de recuperação de livros raros não chega sequer a $50 \%$ do total subtraído, num contexto onde estes exemplares são únicos e muito importantes para a memória nacional, sendo necessário um índice maior de recuperação.

\subsection{Sugestões para futuras pesquisas}

Durante a realização desse trabalho foi constatada a necessidade da exploração aprofundada de alguns temas. Devido à complexidade e à quantidade de variáveis que a segurança contra roubo e furto e mais amplamente a preservação de livros raros contém são sugeridos abaixo assuntos que podem ser abordados em futuros trabalhos.

Nesse trabalho partiu-se do pressuposto que o conteúdo do livro raro é muito importante para a história e patrimônio humanos, argumento evidenciado no tópico, que contextualiza o livro raro como parte integrante da memória coletiva e individual. Portanto, procurou-se dar maior ênfase nos aspectos extra textuais do livro que também fazem dele um objeto informacional. Por isso surge a necessidade de identificar e analisar a importância do livro raro, principalmente do seu conteúdo textual, na criação de uma identidade nacional, social e a sua influência internacional, fora da sua zona de produção. Ou seja, é preciso mostrar o impacto do livro raro na sociedade e na história humana e sua relevância na transmissão de 
conhecimento. Nesse contexto, ainda pode ser analisado o impacto do livro raro na produção científica nacional, de modo a identificar qual o papel do conteúdo desse acervo nas pesquisas científicas realizadas no Brasil. Essas pesquisas podem permitir que seja avaliada a necessidade de maior divulgação do acervo ou do aumento das ferramentas de proteção ao mesmo.

Quanto às ferramentas de proteção contra roubo e furto e todo o universo que envolve a ação criminosa, notou-se importante o estudo aprofundado sobre o comércio ilegal de livros raros e também dos bens culturais no todo. Pois, torna-se relevante entender como são feitos as parcerias comerciais, quais os valores praticados, quais os destinos geográficos dos bens subtraídos, entre outros aspectos. Também nesse sentido, pode ser analisado o tráfico internacional dessas obras, como também as características dos exemplares subtraídos, buscando mostrar a preferência dos criminosos e compradores, para que sejam melhorados os níveis de proteção nas obras.

No presente trabalho foram estudados mais a fundo as medidas de dissuasão legais, como a prevenção situacional, a eficácia policial e o rigor penal. No entanto, ao longo do trabalho verificou-se que também exercem função de dissuasão para não cometimento do crime, ou mesmo o contrário, exercem meios de incentivo à ação ilegal o contexto social em que o criminoso está inserido e mesmo suas características psicológicas. Portanto, fica como sugestão um futuro estudo sobre as variáveis sociais e psicológicas em que o criminoso está imerso, principalmente no universo do roubo e furto de livros raros, fazendo levantamento sobre a sua criação, estrutura familiar, moradia, nível escolar, convicções religiosas, pessoais e políticas, entre outros aspectos.

$\mathrm{Na}$ revisão de literatura foram levantados vários casos de roubo e furto a livros raros e ao patrimônio histórico e cultural, não só no Brasil como em vários outros países. Nos 15 casos estudados mais profundamente, em que há roubo ou fruto de ao menos um livro raro, não foi possível verificar a participação de funcionários da Coleção de livros raros ou mesmo de outros setores da instituição lesada, característica essa identificada em outros crimes a instituições guardiãs de bens culturais. Por isso, torna-se importante a análise dos aspectos que envolvem a 
participação de funcionários nesse tipo de crime, como o que leva ele a aceitar colaborar com o criminoso, tornando-se também um transgressor da lei, ou como estes agem para encobrir seus rastros na ação e o desaparecimento das obras, ou mesmo como esses usam seus conhecimentos sobre o acervo e sobre a instituição para ajudar na execução do crime, além de outros fatores que podem ser analisados.

Foram apontadas aqui, algumas medidas, que podem ser utilizadas pelas instituições para tentar evitar o roubo ou furto de seus materiais, como também podem ajudar na recuperação do mesmo caso venha a ocorrer o crime. Essas ferramentas estão intimamente ligadas às tecnologias de vigilância e de avisos de invasão. Pode-se, assim, realizar um estudo aprofundado das tecnologias que estão envolvidas em programas de segurança de modo a identificar as variações entre produtos, a relação de custo e benefício da aplicação de determinado item e a evolução tecnológica e sua possível obsolescência, entre outros aspectos.

Nas entrevistas presente nesse trabalho, foi questionado sobre a opinião dos especialistas sobre o uso de marcas de propriedade. A resposta deles não foi unânime e isso se deve ao fato dos possíveis danos causados pelas marcas em contraposição à sua importância na identificação da instituição guardiã da obra. Portanto, é possível por meio de estudo e pesquisa levantar como as instituições que preservam bens culturais lidam com este problema nos diversos tipos de objetos e as razões para adoção ou não das marcas. Também se pode realizar um trabalho sobre a qualidade dos materiais usados para marcação nas variadas instituições, como por exemplo, da tinta do carimbo, ou mesmo do impacto visual e estrutural causado às obras em longo prazo, como por exemplo, nos carimbos a seco. $\mathrm{Na}$ análise de alguns crimes, no presente trabalho, verificou-se a retirada da marca de propriedade por meio de exclusão física ou da adição de produtos químicos. Nesses casos é possível verificar que havia ali alguma marcação, no entanto, o seu conteúdo nem sempre está disponível, fazendo com que a seja perdida a finalidade da marca de propriedade. Todos esses aspectos levantados podem fazer parte sobre um estudo específico sobre a marca de propriedade adotada nas instituições guardiãs de bens culturais. 


\section{Referências}

ACQUAVIVA, M. C. Dicionário jurídico Acquaviva. São Paulo: Rideel, 2013.

ACRL/RBMS Guidelines Regarding Security and Theft in Special Collections. Chicago: ALA, 2009. Disponível em: <http://www.ala.org/acrl/standards/security_theft>. Acesso em 16 abr. 2013.

AFFAIRE du "manuscrit H 52": prison ferme en appel pour l'ancien conservateur Michel Garel. Le Monde, 26 jan. 2007. Disponível em: <http://www.lemonde.fr/societe/article/2007/01/26/affaire-du-manuscrit-h-52-prisonferme-en-appel-pour-I-ancien-conservateur-michel-garel_860385_3224.html>. Acesso em: 06 fev. 2012.

AGUIAR JÚNIOR, R. R. Aplicação da pena. Informativo Jurídico da Biblioteca Ministro Oscar Saraiva, v. 13, n. 2, p. 127-280, jul./dez. 2001. Disponível em: < http://www2.stj.jus.br/publicacaoseriada/index.php/informativo/article/view/255/249>. Acesso em: 18 jul. 2014.

ALMEIDA, S. A. F. Prefácio. In: ONO, R.; MOREIRA, K. B. R. Segurança em museus. Brasília: Ibram, 2011. Disponível em: <http://www.museus.gov.br/wpcontent/uploads/2012/08/Seguranca-em-Museus.pdf>. Acesso em: 17 fev. 2014.

AMAZONAS, M. B. L. A. Coleção dos Oratorianos da Biblioteca da Faculdade de Direito de Recife: inventário e conservação, in Anais da Biblioteca Nacional, Rio de Janeiro, v. 128, p. 195-210, 2008. Disponível em: <http://objdigital.bn.br/acervo_digital/anais/anais_128_2008.pdf>. Acesso em: 04 jun. 2013.

ANDRADE, A. C. N. Microfilmagem ou digitalização? O problema da escolha certa. In: SILVA, Z. L. (Org). Arquivos, patrimônio e memória: trajetórias e perspectivas. São Paulo: Editora Unesp, 1999, p. 99-112.

ANDRADE, M. Paulicéa desvairada. São Paulo: Casa Mayença, 1922.

APÓS ROUBO, "O Grito" e "A Madonna" de Munch são restaurados. Estadão, 05 mar. 2008. Disponível em: <http://www.estadao.com.br/noticias/arteelazer,aposroubo-o-grito-e-a-madonna-de-munch-sao-restaurados,135464,0.htm>. Acesso em: 06 fev. 2012.

ARAÚJO, E. A construção do livro: [princípios da técnica de editoração]. São Paulo: Editora UNESP, 2008.

ARAÚJO, L. P. Imagens da violência: um ensaio sobre a psicossociologia dos grupos violentos e suas perspectivas compreensivas. Revista Incelências, v. 2, n. 1, p. 54-73, 2011. Disponível em: <http://www.fejal.com.br/revista/index.php/incelencias/article/viewFile/107/69>. Acesso em: 03 mar. 2013. 
ASSIS, S. G.; CONSTANTINO, P. Perspectivas de prevenção da infração juvenil masculina. Ciência \& Saúde Coletiva, v. 1, n. 10, p. 81-90, 2005. Disponível em: <http://www.scielo.br/pdf/\%0D/csc/v10n1/a08v10n1.pdf>. Acesso em: 03 abr. 2013.

AZEVEDO, A. B.; FURLAN, E. C. Finalidade da pena ante o princípio da necessidade das reações penais. Revista do Curso de Direito da Faculdade de Humanidades e Direito, v. 10, n. 10, p. 138-155, 2013. Disponível em: $<$ https://www.metodista.br/revistas/revistas-ims/index.php/RFD/article/viewFile/4787 /4070>. Acesso em: 18 jul. 2014.

AZEVEDO, C. Ex libris. Usina de letras, 08 out. 2002. Disponível em: <http://www.usinadeletras.com.br/exibelotexto.php?cod=11822\&cat=Artigos\&vinda>. Acesso em: 06 fev. 2012.

BARBETTA, P. A. Estatística aplicada às Ciências Sociais. Florianópolis: Editora da UFSC, 2004.

BARRIOS, V. M. A modernidade do livro de arte brasileiro: a Sociedade dos Cem Bibliófilos do Brasil na coleção de obras raras da UnB. In: ENCONTRO NACIONAL DA ASSOCIAÇÃO NACIONAL DE PESQUISADORES EM ARTES PLÁSTICAS PANORAMA DA PESQUISA EM ARTES VISUAIS, 17, 2008, Florianópolis. Disponível em: <http://www.anpap.org.br/anais/2008/artigos/074.pdf>. Acesso em: 18 mai. 2011.

BARTLETT, A. H. O homem que amava muito os livros: a história real de um ladrão bibliófilo, um detetive e os bastidores do universo dos colecionadores literários. São Paulo: Seoman, 2013.

BECKER, G. S. Crime and punishment: an economic approach. Journal of Political Economy, Chicago, v. 76, n. 2, p. 169-217, mar./abr., 1968. Disponível em: <http://www.jstor.org/discover/10.2307/1830482?uid=3737664\&uid=2129\&uid=2134 \&uid $=368085011$ \&uid $=2 \&$ uid $=70 \&$ uid $=3 \&$ uid $=368085001$ \&uid $=60 \&$ sid $=21101726519$ 613>. Acesso em: 03 mar. 2013.

BEDINELLI, T. Assaltantes levam obras raras do Instituto de Botânica de SP. Folha de São Paulo, 02 fev. 2012. Disponível em: <http://www1 .folha.uol.com.br/cotidiano/1043318-assaltantes-levam-obras-raras-doinstituto-de-botanica-de-sp.shtml>. Acesso em: 03 fev. 2012.

BERTINAZZO, S. M. F. Ex libris: pequeno objeto do desejo. Brasília: EdUnB, 2012.

BIBLIOTECA Mário de Andrade descobre furto de obras raras. Folha de São Paulo, $062006 . \quad$ set. Disponível em: <http://www1.folha.uol.com.br/folha/cotidiano/ult95u125688.shtml>. Acesso em: 14/08/2010.

BIBLIOTECA NACIONAL (Brasil). Planor. Critérios de raridade: empregados para a qualificação de obras raras. Rio de Janeiro: FBN, [2000]. Disponível em: <http://www.bn.br/Planor/documentos.html>. Acesso em: 22 abr. 2013. 
BIBLIOTECA NACIONAL (Brasil). Planor. Disponível em: <http://www.bn.br/Planor/>. Acesso em: 01 dez. 2011.

BIBLIOTECA PÚBLICA DO ESTADO, Porto Alegre. Catálogo de obras raras ou valiosas da biblioteca pública do estado. Porto Alegre: Globo, 1972.

BOOK ARTS IN THE USA. New York: Center for Book Arts, 1990.

BRANDALISE, V. H. Gravura rara do século 19 volta para a Mário de Andrade. Estadão, 20 jan. 2011. Disponível em: <http://saopaulo.estadao.com.br/noticias/geral,gravura-rara-do-seculo-19-volta-para-a-mariode-andrade-imp-,668556>. Acesso em: 07 jul. 2014.

BRANDT, R. Bando invade museu e leva livros e obras raras. O Estado de S. Paulo, 13 ago. 2013a. Disponível em: <http://digital.estadao.com.br/download/pdf/2013/08/13/A15.pdf>. Acesso em: 07 jul. 2014.

Polícia Civil prende quadrilha que roubava obras de arte. Estadão, 7 nov. 2013b. Disponível em: <http://www.estadao.com.br/noticias/geral,policia-civil-prendequadrilha-que-roubava-obras-de-arte,1094315>. Acesso em: 20 jul. 2014.

BRASIL. Código penal. Disponível em: <http://www.planalto.gov.br/ccivil_03/decretolei/del2848.htm>. Acesso em 04 jun. 2013.

BRASIL. Constituição da República Federativa do Brasil de 1988. Disponível em: <http://www.planalto.gov.br/ccivil_03/constituicao/constituicao.htm>. Acesso em: 04 jun. 2013.

BRASIL. Decreto n. 3.166, de 14 de setembro de 1999. Promulga a Convenção da UNIDROIT sobre Bens Culturais Furtados ou llicitamente Exportados, concluída em Roma, em 24 de junho de 1995. Disponível em: <http://www.planalto.gov.br/ccivil_03/decreto/d3166.htm>. Acesso em: 04 jun. 2013.

BRASIL. Decreto no 65.347, de 13 de outubro de 1969. Regulamenta a Lei o 5.471, de 09 de junho de 1968, que dispõe sôbre a exportação de livros antigos e conjuntos bibliográficos. Disponível em: <http://www2.cultura.gov.br/site/wpcontent/uploads/2007/10/decreto-65347.pdf>. Acesso em: 04 jun. 2013.

BRASIL. Decreto n. 72.312, de 31 de maio de 1973. Promulga a Convenção sobre as Medidas a serem Adotadas para Proibir e impedir a Importação, Exportação e Transportação e Transferência de Propriedades llícitas dos Bens Culturais. Disponível em: <http://www.planalto.gov.br/ccivil_03/decreto/19701979/D72312.htm>. Acesso em: 04 jun. 2013.

BRASIL. Decreto-lei n. 25, de 30 de novembro de 1937. Organiza a proteção do patrimônio histórico e artístico nacional. Disponível em: <http://www.planalto.gov.br/ccivil_03/decreto-lei/del0025.htm>. Acesso em: 04 jun. 2013. 
BRASIL. Decreto-lei n`3.914, de 09 de dezembro de 1941. Lei de introdução do Código Penal (decreto-lei n. 2.848, de 07-12-940) e da Lei das Contravenções Penais (decreto-lei n. 3.688, de 03 outubro de 1941). Disponível em: <http://www.planalto.gov.br/ccivil_03/decreto-lei/Del3914.htm>. Acesso em: 03 mar. 2013.

BRASIL. Instituto do Patrimônio Histórico e Artístico Nacional. Instrução Normativa $n^{\circ}$ 01, 11 de junho de 2007. Dispõe sobre o Cadastro Especial dos Negociantes de Antiguidades, de Obras de Arte de Qualquer Natureza, de Manuscritos e Livros Antigos ou Raros, e dá outras providências. Disponível em: $<$ http://portal.Iphan.gov.br/portal/baixaFcdAnexo.do?id=338>. Acesso em: 04 jun. 2013.

BRASIL. Instituto do Patrimônio Histórico e Artístico Nacional. Portaria n. 11, de 11 de setembro de 1986. Disponível em: < http://portal.jphan.gov.br/portal/baixaFcdAnexo.do?id=325>. Acesso em: 04 ago. 2014.

BRASIL. Instituto do Patrimônio Histórico e Artístico Nacional. Portaria n. 262, de 14 de agosto de $1992 . \quad$ Disponível em: $<$ http://portal.Iphan.gov.br/portal/baixaFcdAnexo.do?id=338>. Acesso em: 04 jun. 2013.

BRASIL. Justiça Federal do Rio de Janeiro. 1ㄹ Vara Federal Criminal. Processo criminal $n^{\circ}$ 0523293-31.2004.4.02.5101. Autuado em 05 ago. 2004. Sorteio automático para a $1^{\text {a }}$ Vara Federal Criminal em 28 mar. 2006.

BRASIL. Justiça Federal do Rio de Janeiro. $2^{\text {a }}$ Vara Federal Criminal. Sentença do processo criminal no 0517641-33.2004.4.02.5101. Proferida em 19 nov. 2008. Disponível em: <http://procweb.jrrj.jus.br/portal/consulta/cons_procs.asp>. Acesso em: 09 abr. 2014.

BRASIL. Justiça Federal do Rio de Janeiro. 4 ${ }^{\mathrm{a}}$ Vara Federal Criminal. Processo criminal $n^{\circ}$ 0800583-02.2008.4.02.5101. Autuado em 28 jan. 2008.

BRASIL. Justiça Federal do Rio de Janeiro. 6 ${ }^{\underline{a}}$ Vara Federal Criminal. Processo criminal $n^{\circ}$ 0513911-48.2003.4.02.5101. Autuado em 02 set. 2003.

BRASIL. Justiça Federal do Rio de Janeiro. 6 ${ }^{\text {a }}$ Vara Federal Criminal. Sentença do processo criminal no 0807693-18.2009.4.02.5101. Proferida em 20 abr. 2010. Disponível em: <http://procweb.jrrj.jus.br/portal/consulta/cons_procs.asp>. Acesso em: 09 abr. 2014.

BRASIL. Justiça Federal do Rio de Janeiro. 10 ${ }^{\mathrm{a}}$ Vara Federal Criminal. Processo criminal $n^{\circ}$ 0514146-78.2004.4.02.5101. Autuado em 13 mai. 2004. Redistribuição para a 10를 Vara Federal Criminal do Rio de Janeiro em 24 jan. 2012.

BRASIL. Justiça Federal do Rio de Janeiro. 10 ${ }^{\mathrm{a}}$ Vara Federal Criminal. Processo criminal no 0509504-91.2006.4.02.5101. Autuado em 20 abr. 2006. Redistribuição para a 10 ${ }^{\text {a }}$ Vara Federal Criminal do Rio de Janeiro em 03 fev. 2012. 
BRASIL. Justiça Federal do Rio de Janeiro. Tribunal Regional Federal da $2^{\underline{a}}$ Região. Acórdão da apelação criminal no ACR/6763. Proferido em 09 fev. 2010. Processo de origem na $2^{\underline{a}}$ Vara Federal Criminal de no 0517641-33.2004.4.02.5101. Disponível em: http://www.trf2.gov.br/cgi-bin/pingres?proc=200851018153443\&mov=>. Acesso em: 09 abr. 2014.

BRASIL. Justiça Federal do Rio de Janeiro. Tribunal Regional Federal da $2^{a}$ Região. Acórdão da apelação criminal no ACR/8022. Proferido em 24 nov. 2010. Processo de origem na 6 ${ }^{\underline{a}}$ Vara Federal Criminal de no 0807693-18.2009.4.02.5101. Disponível em: http://www.trf2.gov.br/cgi-bin/pingres?proc=200851018153443\&mov=>. Acesso em: 09 abr. 2014.

BRASIL. Justiça Federal do Rio de Janeiro. Tribunal Regional Federal da $2^{a}$ Região. Acórdão da apelação criminal no ACR/8341. Proferido em 23 mai. 2011. Processo de origem na 6 ${ }^{\text {a }}$ Vara Federal Criminal de no 0513911-48.2003.4.02.5101. Disponível em: http://www.trf2.gov.br/cgi-bin/pingres?proc=200851018153443\&mov=>. Acesso em: 09 abr. 2014.

BRASIL. Justiça Federal do Rio de Janeiro. Tribunal Regional Federal $2^{\mathfrak{a}}$ Região. Acórdão dos embargos infringentes no ENUL/6612. Proferido em 03 dez. 2010. Processo de origem na $2^{a}$ Vara Federal Criminal de no 0517641-33.2004.4.02.5101. Disponível em: http://www.trf2.gov.br/cgibin/pingres?proc=200851018153443\&mov=>. Acesso em: 09 abr. 2014.

BRASIL. Justiça Federal do Rio de Janeiro. Tribunal Regional Federal da $2^{\text {a }}$ Região. Decisão sobre pedido de recursos especiais na apelação criminal no ACR/8022. Proferida em 18 fev. 2011. Processo de origem na 6a Vara Federal Criminal de $\mathrm{n}^{\mathbf{0}}$ 0807693-18.2009.4.02.5101. Disponível em: http://www.trf2.gov.br/cgibin/pingres ?proc=200851018153443\&mov=>. Acesso em: 09 abr. 2014.

BRASIL. Justiça Federal do Rio de Janeiro. Tribunal Regional Federal da $2^{a}$ Região. Decisão sobre pedido de recursos especiais na apelação criminal no ACR/8341.

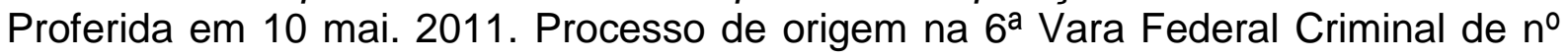
0513911-48.2003.4.02.5101. Disponível em: http://www.trf2.gov.br/cgibin/pingres ?proc=200851018153443\&mov=>. Acesso em: 09 abr. 2014.

BRASIL. Lei n. 5.471, de 09 de julho de 1968. Dispõe sôbre a exportação de livros antigos e conjuntos bibliográficos brasileiros. Disponível em: <http://www.planalto.gov.br/ccivil_03/leis/L5471.htm>. Acesso em: 04 jun. 2013.

BRASIL. Lei n. 5.869, de 11 de janeiro de 1973. Institui o Código de Processo Civil. Disponível em: <http://www.planalto.gov.br/ccivil_03/leis/15869.htm>. Acesso em: 08 dez. 2014.

BRASIL. MINISTÉRIO DA CULTURA. Assalto à Chácara do Céu. 01 mar. 2006. Disponível em: <http://www2.cultura.gov.br/site/2006/03/01/assalto-a-chacara-doceu/>. Acesso em: 03 fev. 2012.

BRASIL. Superior Tribunal de Justiça. Decisão do recurso especial $n^{\circ}$ 1256898/RJ. Proferida em 14 nov. 2013. Processo de origem na 6ª Vara Federal Criminal do Rio 
de Janeiro de $\mathrm{n}^{0}$ 0807693-18.2009.4.02.5101. Disponível em: <http://www.stj.jus.br/portal_stj/>. Acesso em: 09 abr. 2014.

BRASIL. Tribunal de Justiça do Estado de São Paulo. 7ª Câmara de Direito Criminal. Decisão sobre a apelação criminal no 993.06.065158-7. Proferida em 21 ago. 2008. In: BRASIL. Justiça Federal do Rio de Janeiro. 10 $0^{\mathrm{a}}$ Vara Federal Criminal. Processo criminal $n^{\circ}$ 0509504-91.2006.4.02.5101. Autuado em 20 abr. 2006. Redistribuição para a 10 a Vara Federal Criminal do Rio de Janeiro em 03 fev. 2012.

BRASIL. Tribunal de Justiça do Estado de São Paulo. 30 ${ }^{\text {a }}$ Vara Criminal da Capital. Sentença do processo criminal no 050.04.038423-3. Proferida em 04 nov. 2005. In: BRASIL. Justiça Federal do Rio de Janeiro. 10 ${ }^{\mathrm{a}}$ Vara Federal Criminal. Processo crimal no 0509504-91.2006.4.02.5101. Autuado em 20 abr. 2006. Redistribuição para a 10 ${ }^{\text {a }}$ Vara Federal Criminal do Rio de Janeiro em 03 fev. 2012.

BRASIL. Tribunal de Justiça do Paraná. 11a Vara Criminal do Foro Central de Curitiba. Processo Criminal no 2007.0003086-7. Recebimento da Denúncia em 20 jun. 2008.

BRISTOW, M. Roubo de obras de arte na Cidade Proibida constrange autoridades chinesas. BBC Brasil, 11 mai. 2011. Disponível em: $<$ http://www.bbc.co.uk/portuguese/noticias/2011/05/110511_china_cidade_proibida_r oubo_fn.shtml>. Acesso em: 03 fev. 2012.

BRITO, D.; MARTINS, M. A. Ladrão de obras raras age de dentro de presídio. Folha de S. Paulo, 15 jul. 2012. Disponível em: $<$ http://www1.folha.uol.com.br/cotidiano/2012/07/1120307-ladrao-de-obras-rarasage-de-dentro-de-presidio.shtml>. Acesso em: 25 jul. 2014.

BROWN, K. E.; PATKUS, B. L. Collections Security: Planning and Prevention for Libraries and Archives. Andover: Northeast Document Conservation Center, [20--?]. Disponível em: <https://www.nedcc.org/free-resources/preservation-leaflets/3.emergency-management/3.11-collections-security-planning-and-prevention-forlibraries-and-archives>. Acesso em 04 dez. 2014.

BRUCHARD, D. A encadernação. 1999. Disponível em: <http://escritoriodolivro. com.br>. Acesso em: 18 mai. 2011.

BUCKLAND, M.K. Information as thing. Journal of the American Society for Information Science, v. 42, n. 5, p. 351-360, 1991.

CADERNO com desenhos de Picasso é roubado de museu em Paris. Estadão, 09 jun. 2009. Disponível em: <http://www.estadao.com.br/noticias/arteelazer,cadernocom-desenhos-de-picasso-e-roubado-de-museu-em-paris,384764,0.htm>. Acesso em: 03 fev. 2012.

CALDEIRA, P. S. Corte do mangue: breves considerações. Rio de Janeiro: J Villeneuve, 1884.

CAMPBELL, D. Dealer who stole rare maps faces jail and $£ 1 \mathrm{~m}$ fines. The Guardian, 24 jun. 2006. Disponível em: 
<http://www.guardian.co.uk/uk/2006/jun/24/books.ukcrime>. Acesso em: 06 fev. 2012.

CANETA QUE PERTENCEU a Afonso Pena é furtada do Museu da República. Ibram, 04 abr. 2013. Disponível em: <http://www.museus.gov.br/ibram-informaroubo-de-objeto-do-acervo-do-museu-da-republica/>. Acesso em: 30 jul. 2014.

CAPURRO, R. Epistemologia e ciência da informação. In: ENCONTRO NACIONAL DE PESQUISA EM CIÊNCIA DA INFORMAÇÃO, 5., 2003, Belo Horizonte. Anais... Belo Horizonte: Enancib, 2003. Disponível em: <http://www.capurro.de/enancib_p.htm>. Acesso em: 18 jun. 2012.

CAPURRO, R.; HJØRLAND, B. O conceito de informação. Perspectivas em Ciência da Informação, v.12, n.1, p.148-207, 2007. Disponível em: <http://portaldeperiodicos.eci.ufmg.br/index.php/pci/article/view/54>. Acesso em: 18 jun. 2012.

CARDOSO, W. livros raros estavam em sacos de lixo na rua. Estado de São Paulo, 04 abr. 2012. Disponível em: <http://sao-paulo.estadao.com.br/noticias/geral,livrosraros-estavam-em-sacos-de-lixo-na-rua-imp-,857134 >. Acesso em: 24 jun. 2014.

CARRELL, S. Duke tells trial of emotion over theft of Da Vinci from castle. The Guardian, 03 out. 2010. Disponível em: <http://www.guardian.co.uk/artanddesign/2010/mar/03/leonardo-duke-buccleuchtrial>. Acesso em: 03 fev. 2012.

CARVAJAL, D. A Picasso and a Gauguin are among 7 works stolen from a dutch museum. The New York Times, 16 out. 2012. Disponível em: <http://www.nytimes.com/2012/10/17/world/europe/Picasso-and-Monets-Are-StolenFrom-Dutch-Museum.html>. Acesso em: 03 fev. 2012.

CARVALHO, M. C.; GALLO, R. Biblioteca Mário de Andrade perde parte de acervo histórico. Folha de São Paulo, 09 jul. 2006. p. C1.

CARVALHO, T. M. P. A ocasião faz o ladrão. Revista eletrônica de Ciências Jurídicas. Maranhão: Ministério Público do Estado do Maranhão, 2004. Disponível em: <http://www2.mp.ma.gov.br/ampem/artigos/Artigos2005-2/AOcasiaoFazLadraoRECJ.02.04-05.pdf>. Acesso em 03 dez. 2014.

CENTRO DE FILOSOFIA E CIÊNCIAS HUMANAS. Universidade Federal do Rio de Janeiro. Obra rara. Rio de Janeiro: UFRJ, [s. d.]. Disponível em: <http://www.cfch.ufrj.br/index.php/obras-raras>. Acesso em: 22 abr. 2013.

CERQUEIRA, D.; LOBÃO, W. Determinantes da criminalidade: arcabouços teóricos e resultados empíricos. DADOS - Revista de Ciências Sociais, Rio de Janeiro, v. 47, n. 2, p. 233-269, 2004. Disponível em: <http://www.scielo.br/pdf/dados/v47n2/a02v47n2.pdf>. Acesso em: 03 mar. 2013.

CHRISTIE`S. Disponível em: <http://www.christies.com/>. Acesso em: 07 jan. 2012. 
CONDENADOS HOMENS que roubaram telas de Van Gogh. Estadão, 26 jul. 2004. Disponível em: <http://www.estadao.com.br/arquivo/arteelazer/2004/not20040726p7309.htm>. Acesso em: 02 fev. 2012.

COSTA, T. P.; ROCHA, J. S. A incidência da receptação e do tráfico ilícito de obras de arte no Brasil. Revista do Curso de Direito, São Paulo, v. 4, n. 4, 2007. Disponível em: <https://www.metodista.br/revistas/revistas-ims/index.php/RFD/article/view/525>. Acesso em: 04 jun. 2013.

COZER, R. Publicações raras e documentos históricos são alvos de quadrilhas. Folha de São Paulo, 21 jan. 2014. Disponível em: <http://www1.folha.uol.com.br/ilustrada/2014/01/1400456-publicacoes-raras-edocumentos-historicos-sao-alvos-de-quadrilhas.shtml>. Acesso em: 02 jul. 2014.

CUMMING, L. The man who stole the Mona Lisa. The Guardian, 05 ago. 2011. Disponível em: <http://www.guardian.co.uk/artanddesign/2011/aug/05/mona-lisatheft-louvre-leonardo>. Acesso em: 03 fev. 2012.

CUNHA, L. Critérios empregados para a qualificação de livros raros. Rio de Janeiro: Biblioteca Nacional, 1984. 1 f. datilografada.

CUNHA, M. B.; CAVALCANTI, C. R. O. Dicionário de Biblioteconomia e Arquivologia. Brasília: Briquet de Lemos, 2008.

DAVIES, L.; JONES, S. Paris art museum theft the work of lone robber. The Guardian, 20 mai. 2010. Disponível em: <http://www.guardian.co.uk/artanddesign/2010/may/20/picasso-matisse-stolen-parismuseum>. Acesso em: 03 fev. 2012.

DIAS, E. M. S.; SILVA, I. M.; RODRIGUES, J. G. Inventário da Coleção de Periódicos Raros da Biblioteca de Ciências Biomédicas, ICICT/Fundação Oswaldo Cruz, in Anais da Biblioteca Nacional, Rio de Janeiro, v. 128, p. 205-48, 2008. Disponível em: <http://objdigital.bn.br/acervo_digital/anais/anais_128_2008.pdf>. Acesso em: 04 jun. 2013.

DIREITONET. Disponível em: < http://www.direitonet.com.br/>. Acesso em 08 dez. 2014.

EDMONDSON, R. Memória do Mundo: diretrizes para a salvaguarda do patrimônio documental. [s.l.]: Unesco, 2002.

EGITO CONDENA 11 à prisão por roubo de tela de Van Gogh. Gazeta do Povo, 12 dez. $2010 . \quad$ Disponível em: $<$ http://www.gazetadopovo.com.br/mundo/conteudo.phtml?id=1056509\&tit=Egitocondena-11-a-prisao-por-roubo-de-tela-de-Van-Gogh>. Acesso em: 03 fev. 2012.

EL FBI recupera en Nueva Jersey el cuadro de Goya "Niños del Carretón". El Mundo, 21 nov. 2006.2 Disponível em: <http://www.elmundo.es/elmundo/2006/11/20/cultura/1164053589.html>. Acesso em: 06 fev. 2012. 
ELLISON, M. Peace is high price for a stolen Chagall. The Guardian, 21 ago. 2001. Disponível em: <http://www.guardian.co.uk/world/2001/aug/21/israel.arttheft?INTCMP=SRCH>. Acesso em: 03 fev. 2012.

ELTON, E.; FERNANDES, H. B. O Ex libris e o Barão do Rio Branco. Rio de Janeiro: [s.n.], 1953.

ESCULTURA DE OURO de $R \$ 160$ milhões é roubada na Áustria. BBC Brasil, 11 mai. $2003 . \quad$ Disponível em: <http://www.bbc.co.uk/portuguese/cultura/030511_austriaxmt.shtml>. Acesso em: 02 fev. 2012.

ESCULTURA DE RODIN roubada é encontrada. Folha de São Paulo, 18 jun. 2005. Disponível em: <http://www1.folha.uol.com.br/fsp/ilustrad/fq1806200532.htm>. Acesso em: 06 fev. 2012.

ESTEVES, M. O Ex libris. $2^{\mathrm{a}}$ ed. Rio de Janeiro: Laemmert, 1956.

EX-FUNCIONÁRIO de biblioteca francesa pega 15 meses por furto. Folha de São Paulo, São Paulo, 26 jan. 2007. Disponível em: <http://www1.folha.uol.com.br/folha/ilustrada/ult90u67910.shtml>. Acesso em: 14 ago. 2010.

FAIRBANKS, P. Buffalo man accused of stealing documents from History Museum. The Buffalo News, 28 mai. 2013. Disponível em: <http://www.nytimes.com/2012/10/17/world/europe/Picasso-and-Monets-Are-StolenFrom-Dutch-Museum.html>. Acesso em: 08 jun. 2013.

FARIA, M. I.; PERICÃO, M. G. Dicionário do livro: da escrita ao livro eletrônico. São Paulo: Edusp, 2008.

FEBVRE, L.; MARTIN, H. O aparecimento do livro. Lisboa: Fundação Calouste Gulbenkian, 2000.

FERREIRA, M. Introdução à preservação digital: conceitos, estratégias e actuais consensos. Guimarães, Portugal: Escola de Engenharia da Universidade do Minho, 2006. Disponível em: <http://hdl.handle.net/1822/5820>. Acesso em: 07 jan. 2012.

FROES, R. C. obras raras no Brasil: estudos dos critérios de raridade bibliográfica, tratamento técnico e preservação das coleções. 1995. 155 p. Dissertação (Mestrado em Biblioteconomia) - Universidade Federal de Minas Gerais, Belo Horizonte, 1995. Disponível em:<http://www.bibliotecadigital.ufmg.br/dspace/handle/1843/BUOS8GQHQB>. Acesso em: 09 jun. 2013.

GAUZ, V. Calogação de livros raros - aspectos de segurança. Info Home, fev. 2004. Disponível em: <http://www.ofaj.com.br/colunas_conteudo.php?cod=169>. Acesso em 08 dez. 2014.

De roubos e roubos. Info Home, out. 2005. Disponível em: <http://www.ofaj.com.br/colunas_conteudo.php?cod=231>. Acesso em 16 fev. 2014. 
$\begin{array}{cccc}\text { Home, Da Itália para o mundo: o roubo de livros da Biblioteca Girolamini. Info } \\ \text { dez. } & 2013 . & \text { Disponível } & \text { em: }\end{array}$ <http://www.ofaj.com.br/colunas_conteudo.php?cod=802>. Acesso em 16 fev. 2014.

História e historiadores de Brasil colonial, uso de livros raros digitalizados na comunicação científica e a produção do conhecimento, 1995-2009. 2011. Tese (doutorado) - Programa de Pós-graduação em Ciência da Informação, UFF/IBICT, Niterói, 2011. Disponível em: <http://eprints.rclis.org/16566/1/vgauztese.pdf>. Acesso em: 24 fev. 2014.

Roubo de livros raros: algumas questões morais. Info Home, jul. 2006. Disponível em: <http://www.ofaj.com.br/colunas_conteudo.php?cod=262>. Acesso em 16 fev. 2014.

(Org.). Segurança em acervos raros. Rio de Janeiro: Biblioteca Nacional, 1994.

GIL, A. C. Métodos e técnicas de pesquisa social. 6. ed. São Paulo: Atlas, 2008.

GONÇALVES, E. M. Estudo das estruturas das encadernações de livros do século XIX na Coleção Rui Barbosa: uma contribuição para a conservação-restauração de livros raros no Brasil. 2008. Dissertação (mestrado) - Escola de Belas Artes, UFMG, Belo Horizonte, $2008 . \quad$ Disponível em: <http://www.bibliotecadigital.ufmg.br/dspace/bitstrea m/1843/JSSS7U5K6G/1/disserta_o_edmar_moraes_gon_alves.pdf>. Acesso em: 18 mai. 2011.

GREENHALGH, R. D. Digitalização de obras raras: algumas considerações, in Perspectivas em Ciência da Informação, Belo Horizonte, v. 16, n. 3, p. 159-167, jul./set. $2011 . \quad$ Disponível em: <http://portaldeperiodicos.eci.ufmg.br/index.php/pci/article/viewFile/866/898>. Acesso em: 02 dez. 2011.

GREENHALGH, R. D.; MANINI, M. P. O livro como objeto de arte. In: ENCONTRO NACIONAL DE PESQUISA EM CIÊNCIA DA INFORMAÇÃO, 12., 2011, Brasília. Anais... Brasília: UnB, 2011. 1 CD-ROM.

Segurança de obras raras como possível objeto de estudo da Ciência da Informação. In: TransInformação, Campinas, v. 25, n. 3, p. 255-261, set./dez., 2013.

HALBWACHS, M. A memória coletiva. São Paulo: Centauro, 2006.

HALLEWELL, L. O livro no Brasil. 3. ed. São Paulo: EDUSP, 2012.

HARDING, L. Strange case of the $£ 35 \mathrm{~m}$ saltcellar. The Guardian, 23 jan. 2006. Disponível em: <http://www.guardian.co.uk/artanddesign/2006/jan/23/arttheft.austria>. Acesso em: 03 fev. 2012.

HONIGSBAUM, M. Throw book at thief, says library. The Guardian, 15 set. 2006. Disponível em: <http://www.guardian.co.uk/uk/2006/sep/15/books.ukcrime>. Acesso em: 06 fev. 2012. 
INDICIADO chefe da Biblioteca Nacional francesa. Estadão, São Paulo, 06 ago. 2004. Disponível

em: <http://www.estadao.com.br/arquivo/arteelazer/2004/not20040806p4661.htm>. Acesso em: 08 fev. 2012.

INSTITUTO de Botânica de SP foi avisado há seis meses sobre roubo. Folha de São Paulo, 03 fev. $2012 . \quad$ Disponível em: <http://www1.folha.uol.com.br/cotidiano/1043795-instituto-de-botanica-de-sp-foiavisado-ha-seis-meses-sobre-roubo.shtml>. Acesso em: 07 fev. 2012.

ITZKOFF, F. Two works stolen from Dutch Museum. The New York Times, 01 mai. 2009. Disponível em: <http://www.nytimes.com/2009/05/02/arts/design/02artsTWOWORKSSTOL_BRF.html>. Acesso em: 03 fev. 2012.

KELLY, M. Inequality and crime. The Review of economics and statistics, v. 82, n. 4, p. 530-539, nov. 2000. Disponível em: <http://www.jstor.org/discover/10.2307/2646649?uid=3737664\&uid=2129\&uid=2134 \&uid $=368085011$ \&uid $=2 \&$ uid $=70 \&$ uid $=3 \&$ uid $=368085001$ \&uid $=60 \&$ sid $=21101726519$ 613>. Acesso em: 03 mar. 2013.

KIMBELL, A. Art thieves aren't just in it for the Monet. The Guardian, 07 ago. 2007. Disponível em: $<$ http://www.guardian.co.uk/artanddesign/artblog/2007/aug/07/thehiddenstoryofartthe $\mathrm{ft}>$. Acesso em: 03 fev. 2012.

KNYCHALA, C. H. O livro de arte brasileiro. Rio de Janeiro: Presença, 1983.

KNYCHALA, C. H. O livro ilustrado brasileiro: catálogo. Haia: Rijksmuseum, 1991.

KODAK. Filmes para duplicação e impressão térmica. Disponível em: $<$ http://graphics.kodak.com/Doclmaging/BR/pt/Products/Micrographics/Microfilm/Dupl icating_and_Thermal_Films/index.htm>. Acesso em: 28 fev. 2014.

KUSHNIR, B. Da manchete à notinha de canto: os furtos do patrimônio público, a privatização dos acervos do cidadão. Museologia e Patrimônio, v. 2, p. 9-21, 2009. Disponível em: <http://revistamuseologiaepatrimonio.mast.br/index.php/ppgpmus/issue/current/show Tocm . Acesso em: $01 \mathrm{dez} .2011$.

LABARRE, A. História do livro. São Paulo: Cultrix, 1981.

LACAYO, R. Art's great whodunit: the Mona Lisa theft of 1911. Time entertainment, 27 abr. 2009. Disponível em: <http://www.time.com/time/arts/article/0,8599,1894006,00.html>. Acesso em: 03 fev. 2012.

LADRÕES LEVAM obras de Picasso, Di Cavalcanti e Segall da Estação Pinacoteca. Folha de São Paulo, 12 jun. 2008. Disponível em: <http://www1.folha.uol.com.br/folha/cotidiano/ult95u411729.shtml>. Acesso em: 03 fev. 2012. 
LADRÕES ROUBAM cem obras raras em Campinas. Folha de São Paulo, 13 ago. 2013. Disponível em: < http://www1.folha.uol.com.br/ilustrada/2013/08/1325747ladroes-roubam-cem-obras-raras-em-campinas.shtml>. Acesso em: 19 ago. 2013.

LAVILLE, S. History's missing pages: iranian academic sliced out sections of priceless collection. The Guardian, 21 nov. 2008. Disponível em: <http://www.guardian.co.uk/books/2008/nov/21/british-library-sues-iranianacademic>. Acesso em: 07 fev. 2012.

LE GOFF, J. História e memória. 7. ed. Campinas: Editora da Unicamp, 2013.

LEÃO, S. S. Obra rara é restituída ao Museu Goeldi. Agência Museu Goeldi, 20 mar. 2014. Disponível em: <http://www.museu-goeldi.br/portal/content/obra-rara\%C3\%A9-restitu\%C3\%ADda-ao-museu-goeldi>. Acesso em: 20 jun. 2014

LOS AUTORES DEL ROBO del Kunsthal, condenados a pagar 18 millones. El país, 14 jul. 2014.2 Disponível em: <http://cultura.elpais.com/cultura/2014/07/14/actualidad/1405350502_721048.html>. Acesso em: 30 jul. 2014.

MAIA, M. C. E. S. Severidade punitiva: penas severas: um factor de dissuasão de um crime? 2011. 120 f. Dissertação (Mestrado em Psicologia Forense e da Exclusão Social) - Universidade Lusófona de Humanidades e Tecnologias, Lisboa, 2011. Disponível em: $<$ http://recil.grupolusofona.pt/bitstream/handle/10437/1683/1.\%20Tese_MariaMAIA.p df?sequence=1>. Acesso em: 03 mar. 2013.

MAIA JÚNIOR, H. A Estação Pinacoteca expõe obras recuperadas. Estadão, 27 ago. 2008. Disponível em: <http://www.estadao.com.br/noticias/impresso,estacaopinacoteca-expoe-obras-recuperadas,231310,0.htm>. Acesso em: 03 fev. 2012.

MANGUEL, A. A biblioteca à noite. São Paulo: Companhia das letras, 2006a. . Uma história da leitura. $2^{\mathrm{a}}$ ed. São Paulo: Companhia das Letras, 2006b.

MANSO, B. P.; GODOY, M. Trio rouba livros raros de botânica em SP e diz ser "encomenda internacional". Estadão, 02 fev. 2012. Disponível em: <http://www.estadao.com.br/noticias/cidades,trio-rouba-livros-raros-de-botanica-emsp-e-diz-ser-encomenda-internacional,830662,0.htm >. Acesso em: 07 fev. 2012.

MARCOLIN, N. O preço da velha ciência. Revista de Pesquisa da Fapesp, jul. 2008. Disponível em: <http://revistapesquisa.fapesp.br/2008/07/01/o-preco-da-velhaciencia/>. Acesso em: 03 fev. 2008.

MÁRDERO ARELLANO, M. Á. As coleções de obras raras na biblioteca digital. Brasília, 1998. 93 f. Dissertação (mestrado) - Universidade de Brasília, FACE, 1998.

. Preservação de documentos digitais. Ciência da Informação, Brasília, v. 33, n. 2, p. 15-27, 2004.

MARIO DE ANDRADE resgata livros e gravuras leiloados no Rio. Folha de São Paulo, 26 out. 2006. Disponível em: 
<http://www1.folha.uol.com.br/folha/cotidiano/ult95u127455.shtml>. Acesso em: 14 ago. 2010.

MÁRSICO, M. A. V. O surgimento da encadernação e sua evolução através dos séculos. In: Jornada o livro: uma trajetória, 2., 2010, BN, Rio de Janeiro. Disponível em: <http://www.bn.br/Planor/eventos.html>. Acesso em: 18 mai. 2011.

MARTÍ, S. Obras de arte roubadas são recuperadas em $20 \%$ dos casos. Folha de São Paulo, 18 out. 2012. Disponível em: < http://www1.folha.uol.com.br/ilustrada/1170691-obras-de-arte-roubadas-saorecuperadas-em-20-dos-casos.shtml>. Acesso em: 14 jul. 2014.

MARTINS, I. Gravura: arte e técnica. São Paulo: Nestlé, 1987.

MCGARRY, P. 'Grand theft' of valuable items at All Hallows College in Dublin. The Irish Time, 26 mai. 2014. Disponível em: <http://www.irishtimes.com/news/socialaffairs/religion-and-beliefs/grand-theft-of-valuable-items-at-all-hallows-college-indublin-1.1808786>. Acesso em: 30 jul. 2014.

MCGARRY, P. Items missing from All Hallows College valued in 'thousands'. The Irish Time, 27 mai. 2014. Disponível em: < http://www.irishtimes.com/news/socialaffairs/religion-and-beliefs/items-missing-from-all-hallows-college-valued-inthousands-1.1809984>. Acesso em: 30 jul. 2014.

MCMURTRIE, D. C. O livro: impressão e fabrico. Lisboa: Fundação Calouste Gulbenkian, 1969.

MENDES, S. M. V. Análise económica do crime e o seu contributo para a definição de uma política penal. 1997. 200f. Dissertação (Mestrado em Estudos Económicos e Sociais) - Universidade do Minho, Braga, 1997. Disponível em:<http://repositorium.sdum.uminho.pt/handle/1822/4228>. Acesso em: 03 mar. 2013.

MENESES, R. V. A.; SILVA, L. A. A. A coleção de obras raras da Biblioteca Ministro Oscar Saraiva do Superior Tribunal de Justiça. BDJur, Brasília, 22 jun. 2004. Disponível em: <http://bdjur.stj.gov.br/xmlui/bitstream/handle/2011/25139/Cole\%C3\%A7\%C3\%A3o_ obras_raras_biblioteca.pdf?sequence=3>. Acesso em: $01 \mathrm{dez}$. 2011.

MICHALSKI, S. Care and preservation of collections. In: BOYLAN, P. J. (Ed.). Running a museum: a practical handbook. Paris: International Council of Museums, $2004 . \quad$ p. 51-90. Disponível em: <http://unesdoc.unesco.org/images/0014/001410/141067e.pdf>. Acesso em: $07 \mathrm{dez}$. 2011.

MIRANDA, M. P. S. O inventário como instrumento constitucional de proteção ao patrimônio cultural brasileiro. De jure: revista jurídica do Ministério Público do Estado de Minas Gerais, Belo Horizonte, n. 11, 2008. Disponível em: <http://jus.com.br/revista/texto/11164/o-inventario-como-instrumento-constitucionalde-protecao-ao-patrimonio-cultural-brasileiro>. Acesso em: 04 jun. 2013. 
MORAES, R. B. O bibliófilo aprendiz. $1^{\underline{a} e d .} / 4^{a}$ ed. Brasília: Briquet De Lemos, $1965 / 2005$.

2006.

Livros e bibliotecas no Brasil colonial. 2a ed. Brasília: Briquet De Lemos,

MURGUIA, E. I.; YASSUDA, S. N. Patrimônio histórico-cultural: critérios para tombamento de bibliotecas pelo IPHAN. Perspectivas em Ciência da Informação, Belo Horizonte, v. 12, n. 3, set./dez. 2007. Disponível em: <portaldeperiodicos.eci.ufmg.br/index.php/pci/article/download/148/15>. Acesso em: 04 jun. 2013.

NOBRE, N. CCJ aprova redução de pena para crimes como furto e estelionato. Câmara Notícias, Brasília, 12 dez. 2012. Disponível em: <http://www2.camara.leg.br/camaranoticias/noticias/SEGURANCA/432475-CCJ-

APROVA-REDUCAO-DE-PENA-PARA-CRIMES-COMO-FURTO-E-

ESTELIONATO.html>. Acesso em: 01 ago. 2014.

OBJETOS VALIOSOS são roubados do Museu Egípcio no Cairo. Estadão, 13 fev. 2011. Disponível em: <http://www.estadao.com.br/noticias/arteelazer,objetosvaliosos-sao-roubados-do-museu-egipcio-no-cairo,679031,0.htm>. Acesso em: 03 fev. 2012.

OBRAS RARAS desaparecem da Biblioteca Mário de Andrade. Estadão, 06 set. 2006.

<http://www.estadao.com.br/arquivo/cidades/2006/not20060906p29951.htm>.

Acesso em: 07 fev. 2012.

OLIVEIRA, W. F. Violência e saúde coletiva: contribuições teóricas das ciências sociais à discussão sobre o desvio. Saúde e Sociedade, São Paulo, v. 17, n. 3, p. 42-53, 2008. Disponível em: <http://www.scielo.br/pdf/sausoc/v17n3/06.pdf>. Acesso em: 03 mar. 2013.

ONO, R.; MOREIRA, K. B. R. Segurança em museus. Brasília: Ibram, 2011. Disponível em: <http://www.museus.gov.br/wp-content/uploads/2012/08/Segurancaem-Museus.pdf>. Acesso em: 17 fev. 2014.

OPEN LIBRARY. $2010 . \quad$ Disponível em: <http://openlibrary.org/works/OL11553867W/Descripçam_corografica_do_reyno_de_ Portugal?v=2>. Acesso em: 10 jan. 2012.

PAIVA, A. P. M. A aventura do livro experimental. Belo Horizonte: Autêntica, 2010.

PEDERSOLI JR., J. L.; HOLLÓS, A. C. Gerenciamento de riscos: uma abordagem interdisciplinar. Ponto de Acesso, Salvador, v. 3, n. 1, p. 72-81, abr. 2009. Disponível em <http://www.brapci.ufpr.br/documento.php?dd0=0000005346\&dd1=15f66>. Acesso em: 01 dez. 2011.

PEDERSOLI JR., J. L. Gerenciamento de riscos. In: CURSO DE SEGURANCA DE ACERVOS CULTURAIS, 8., 24-28 mai. 2010. Rio de Janeiro: MAST, 2010. (Apostila distribuída durante curso no Museu de Astronomia e Ciências Afins). 
PF alertou Instituto de Botânica de SP sobre possível roubo de obras. O Globo, 03 fev. 2012. Disponível em: <http://oglobo.globo.com/pais/pf-alertou-instituto-debotanica-de-sp-sobre-possivel-roubo-de-obras-3870949>. Acesso em: 07 fev. 2012.

PINHEIRO, A. V. Catalogação de livros raros: proposta de metodologia de formalização de notas especiais para difusão, recuperação e salvaguarda. In: I ECONTRO NACIONAL DE CATALOGADORES E III ENCONTRO DE ESTUDOS E PESQUISAS EM CATALOGAÇÃO, out. 2012, Rio de Janeiro. Disponível em: $<$ http://pt.scribd.com/doc/109278012/Catalogacao-de-livros-raros-proposta-demetodologia-de-formalizacao-de-notas-especiais-para-difusao-recuperacao-esalvaguarda>. Acesso em: 16 jun. 2014.

livro raro: antecedentes, propósitos e definições. In: SILVA, H. C.; BARROS, M. H. T. C. (Org.s). Ciência da Informação: múltiplos diálogos. Marília: Cultura Acadêmica, 2009a, p. 31-44. Disponível em: <http://www.marilia.unesp.br/Home/Publicacoes/helen_e\%20book.pdf>. Acesso em: 01 dez. 2011.

- Que é livro raro?: uma metodologia para o estabelecimento de critérios de

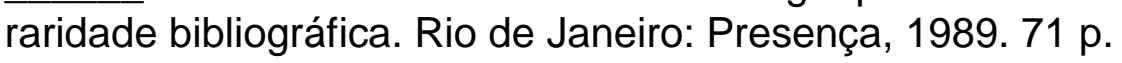

- O livro raro: formação e gestão de coleções bibliográficas especiais. Salvador: [s. n.], 2009b. (Apostila distribuída durante curso no Mosteiro de São Bento de Salvador).

. Metodologia para inventário de acervo antigo. Anais da Biblioteca Nacional, Rio de Janeiro, v. 123, p. 9-32, 2007. Disponível em: $<$ http://www.bn.br/Planor/documentos/anais_123_2003.pdf>. Acesso em: $02 \mathrm{dez}$. 2011.

POLÍCIA FRANCESA recupera Picasso desaparecido. Estadão, 08 abr. 2005. Disponível em: <http://www.estadao.com.br/arquivo/arteelazer/2005/not20050408p5572.htm>. Acesso em: 02 fev. 2012.

POLÍCIA RECUPERA peças roubadas de museu em cidade berço da Olimpíada. Folha de São Paulo, 24 nov. 2012. Disponível em: <http://www1.folha.uol.com.br/mundo/1190774-policia-recupera-pecas-roubadas-demuseu-em-cidade-berco-da-olimpiada.shtml>. Acesso em: 03 fev. 2012.

POLÍCIA SUSPEITA que roubo no Masp foi encomenda de colecionador. Estadão, 20 dez. 2007. Disponível em: <http://www.estadao.com.br/noticias/geral,policiasuspeita-que-roubo-no-masp-foi-encomenda-de-colecionador,99150,0.htm>. Acesso em: 03 fev. 2012.

PONTE, A. C. Aspectos penais da preservação do patrimônio histórico e cultural. Lex. Revista do Direito Brasileiro, v. 1, p. 01-25, 2006. Disponível em: <http://sisnet.aduaneiras.com.br/lex/doutrinas/arquivos/PENAIS>. Acesso em: 03 mar. 2013. 
PREFEITURA divulga lista de obras furtadas da biblioteca Mário de Andrade. Folha de São Paulo, 07 set. 2006. Disponível em: <http://www1.folha.uol.com.br/folha/cotidiano/ult95u125720.shtml>. Acesso em: 14 ago. 2010.

PREJUÍZO por roubo de obras raras pode chegar a $\mathrm{R} \$ 500$ mil. Gazeta do Povo, 08 nov. $2006 . \quad$ Disponível em: <http://www.gazetadopovo.com.br/vidapublica/conteudo.phtml?id=611943>. Acesso em: 07 dez. 2011.

PRIMERA, M. Saque à arte de Cuba. El País Brasil, 4 mar. 2014. Disponível em: <http://brasil.elpais.com/brasil/2014/03/04/cultura/1393900563_445227.html>.

Acesso em: 30 jul. 2014.

PROTT, L. Tráfico ilícito. In: BOYLAN, P. J. (Ed.). Como gerir um museu: manual prático. Paris: ICOM, 2004. p. 214-222. Disponível em: <http://unesdoc.unesco.org/images/0018/001847/184713por.pdf>. Acesso em: 17 fev. 2014.

QUADRA, T. Quadrilha rouba livros raros do CCLA em Campinas. Correio Popular, 09 ago. 2013. Disponível em: < http://correio.rac.com.br/_conteudo/2013/08/capa/campinas_e_rmc/89314-quadrilharouba-livros-raros-do-ccla-em-campinas.html>. Acesso em: 19 ago. 2013.

QUADRO DE CÉZANNE, roubado em 2008, é encontrado por policiais na Sérvia. Correio Braziliense, 12 abr. 2012. Disponível em: <http://www.correiobraziliense.com.br/app/noticia/mundo/2012/04/12/interna_mundo, 297573/quadro-de-cezanne-roubado-em-2008-e-encontrado-por-policiais-naservia.shtml>. Acesso em: 03 fev. 2012.

QUADRO DE CHAGALL roubado é encontrado. BBC Brasil, 23 jan. 2002. Disponível em: <http://www.bbc.co.uk/portuguese/cultura/020123_chagalltp.shtml>. Acesso em: 06 fev. 2012.

QUADRO DE GOYA é roubado no trajeto entre Ohio e Nova York. Estadão, 14 nov. 2006. Disponível em: <http://www.estadao.com.br/arquivo/arteelazer/2006/not20061114p6264.htm>. Acesso em: 06 fev. 2012.

QUADRO DE PICASSO é encontrado atrás de armário. BBC Brasil, 08 abr. 2005. Disponível em: <http://www.bbc.co.uk/portuguese/cultura/story/2005/04/050408_picassodtl.shtml>. Acesso em: 06 fev. 2012.

QUADRO DE RENÉ Magritte é roubado de museu em Bruxelas. Folha de São Paulo, 24 set. 2009. Disponível em: <http://www1.folha.uol.com.br/folha/ilustrada/ult90u628493.shtml>. Acesso em: 03 fev. 2012. 
QUADRO DE VAN GOGH é roubado de um museu do Cairo. Estadão, 21 ago. 2010. Disponível em: <http://www.estadao.com.br/noticias/arteelazer,quadro-de-vangogh-e-roubado-de-um-museu-do-cairo,598352,0.htm>. Acesso em: 03 fev. 2012.

QUADRO É "tomado como refém" em troca da paz no Oriente Médio. BBC Brasil, 21 ago. $2001 . \quad$ Disponível em: <http://www.bbc.co.uk/portuguese/noticias/2001/010821_chagall.shtml>. Acesso em: 06 fev. 2012.

REIFSCHNEIDER, O. D. B. A importância do acesso às obras raras. Revista lberoAmericana de Ciência da Informação, v. 1, n. 1, jan./abr. 2008. Disponível em: <http://seer.bce.unb.br/index.php/RICl/article/view/1544/2330>. Acesso em: 17 jun. 2014.

RARE BOOKS AND MANUSCRIPTS SECTION. RBMS Security Committee: theft reports. $2014 . \quad$ Disponível em: < http://www.rbms.info/committees/security/theft_reports/index.shtml>. Acesso em: 17 jun. 2014.

RESOURCE THE COUNCIL FOR MUSEUMS, ARCHIVES AND LIBRARIES. Segurança de museus. São Paulo: EDUSP, 2003. (Série Museologia: roteiros práticos; 4). Disponível em: <http://www.cerescaico.ufrn.br/museu/documentos/seguranca.pdf>. Acesso em: 02 dez. 2011.

RICHARDSON, R. J. Pesquisa social: métodos e técnicas. 3 ed. São Paulo: Atlas, 2011.

RODRIGUES, A. H.; CALHEIROS, M. F.; COSTA, P. S. Análise bibliológica de livros raros: a preservação ao "pé da letra". Anais da Biblioteca Nacional, Rio de Janeiro, v. 123, p. 33-48, 2007. Disponível em: <http://www.bn.br/Planor/documentos/anais_123_2003.pdf $>$. Acesso em: 02 dez. 2011.

RODRIGUES, J. B. Poranduba amazonense. Rio de Janeiro: Sociedade dos Cem Bibliófilos do Brasil, 1961.

RODRIGUES, Maurício. Livros roubados do Instituto de Botânica são recuperados. Deic, $\quad 03 \quad$ abr. 2012.20 Disponível <http://www2.policiacivil.sp.gov.br/x2016/modules/news/article.php?storyid=2700>. Acesso em: 16 jun. 2014.

RODRIGUES, Márcia C. Como definir e identificar obras raras?: critérios adotados pela Biblioteca Central da Universidade de Caxias do Sul. Revista Ciência da Informação, Brasília, v. 35, n. 1, p. 115-121, jan./abr. 2006. Disponível em: <http://eprints.rclis.org/8336/1/v35n1a12.pdf>. Acesso em: 16 jun. 2014.

ROLIM, M. Uma introdução aos novos paradigmas em segurança pública em segurança pública. Revista Preleção, ano 3, n. 6, p. 43-60, ago. 2009. Disponível em: 
<http://www.pm.es.gov.br/download/reistaprelecao/Revista_Prelecao_Edicao_06.pdf >. Acesso em 03 mar. 2013.

ROUBADOS 24 livros raros do Museu Nacional do Rio. Estadão, 06 mai. 2004. Disponível em: <http://www.estadao.com.br/arquivo/arteelazer/2004/not20040506p7225.htm>. Acesso em: 06 fev. 2012.

ROUBO DE obras raras no Museu Emilio Goeldi. Agência Museu Goeldi, 2008. Disponível em: $<$ http://www.museugoeldi.br/sobre/NOTICIAS/2008/obras_furtadas_d.html>. Acesso em: 06 fev. 2012.

ROUBO NO MASP expõe condições "nefastas" de segurança. Estadão, 21 dez. 2007. Disponível em: <http://www.estadao.com.br/noticias/arteelazer,roubo-nomasp-expoe-condicoes-nefastas-de-seguranca,99473,0.htm>. Acesso em: 03 fev. 2012.

ROUBO NO MUSEU DA REPÚBLICA foi também por falta de segurança, diz diretora. Correio Braziliense, 04 abr. 2013. Disponível em: $<$ http://www.correiobraziliense.com.br/app/noticia/brasil/2013/04/04/interna_brasil,35 8576/roubo-no-museu-da-republica-foi-tambem-por-falta-de-seguranca-dizdiretora.shtml>. Acesso em: 30 jul. 2014.

ROUBO PODE causar prejuízo de R\$2 mi a museu no PA. Estadão, 24 dez. 2008. Disponível em: <http://www.estadao.com.br/noticias/geral,roubo-pode-causarprejuizo-de-r-2-mi-a-museu-no-pa,298581,0.htm>. Acesso em: 06 fev. 2012.

SALVO, M. A Economia do crime e da cultura: o mercado de obras de arte roubadas. Latin American and Caribbean Law and Economics Association (alacde) annual papers, Berkeley, abr. 2010. Disponível em: <http://escholarship.org/uc/item/31m0t07k>. Acesso em: 20 dez. 2011.

SANT'ANA, R. B. Critérios para a definição de obras raras. Revista Online Biblioteca Prof. Joel Martins, Campinas, v. 2, n. 3, p. 1-18, jun. 2001. Disponível em: <http://www.fe.unicamp.br/revista/index.php/etd/article/view/1886/1727>. Acesso em: 02 dez. 2011.

SANTOS, A. S.; ALBUQUERQUE, A. C. Estudo do tratamento técnico das obras raras da biblioteca central da UFMT: uma proposta de manualização para critérios de raridade bibliográfica. In: ENCONTRO NACIONAL DE ESTUDANTES DE BIBLIOTECONOMIA, DOCUMENTAÇÃO, GESTÃO, E CIÊNCIA DA INFORMAÇÃO, XXXIII, 1989. Anais... Paraíba: UFPB, 18 a 24 jul. 2010. Disponível em: < http://dci.ccsa.ufpb.br/enebd/index.php/enebd/article/viewFile/173/117>. Acesso em: 01 jul. 2014.

SANTOS, M. J.; KASSOUF, A. L. Estudos econômicos das causas da criminalidade no brasil: evidências e controvérsias. Economia, Brasília, v. 9, n. 2, p. 343-372, mai/ago 2008. Disponível em: <http://www.anpec.org.br/revista/vol9/vol9n2p343_372.pdf>. Acesso em: 03 mar. 2013. 
SAYÃO, L. F. Segurança da informação em meios eletrônicos. In: CURSO DE SEGURANCA DE ACERVOS CULTURAIS, 8., 24-28 mai. 2010. Rio de Janeiro: MAST, 2010. (Apostila distribuída durante curso no Museu de Astronomia e Ciências Afins).

SCHAEFER, G. J.; SHIKIDA, P. F. A. Economia do crime: elementos teóricos e evidencias empíricas. Análise Econômica, Porto Alegre, ano 19, n. 36, p. 195-217, set. $2001 . \quad$ Disponível em: <http://seer.ufrgs.br/AnaliseEconomica/article/view/10682>. Acesso em: 03 mar. 2013.

SHANNON, C.E.; WEAVER, W. The mathematical theory of communication. Urbana, IL: University of Illinois Press, 1949.

SHIKIDA, P. F. A. Considerações sobre a Economia do Crime no Brasil: um sumário de 10 anos de pesquisa. EALR, Brasília, v. 1, n. 2, p. 318-336, jul./dez. 2010. Disponível em: <http://portalrevistas.ucb.br/index.php/EALR/article/viewArticle/1\%20EALR\%20318>. Acesso em: 03 mar. 2013.

SILVA, F. Critérios de seleção de obras raras adotados em bibliotecas do Distrito Federal. 2011. 154 p. Dissertação (Mestrado em Ciência da Informação) Universidade de Brasília, Brasília, 2011. Disponível em: < http://repositorio.unb.br/bitstream/10482/9202/1/2011_FernandoSilva.pdf>. Acesso em: 16 jun. 2014.

SILVA, M. C. S. M. E. et al. (Org.). Política de segurança para arquivos, bibliotecas e museus. Rio de Janeiro: Museu de Astronomia e Ciências Afins, 2006.

SILVA, S. T. D. G.; LANE, S. S. Uma política de serviços para livros raros em bibliotecas universitárias. In: SEMINÁRIO NACIONAL DE BIBLIOTECAS UNIVERSITÁRIAS, 6., 1989. Anais... Belém: UFPA, 1990. v. 1, p. 119-129. Disponível em: <http://www.dominiopublico.gov.br/download/texto/me001650.pdf>. Acesso em: 26 jan. 2012.

SOTHEBYS. Disponível em: <http://www.sothebys.com/en/departments/booksmanuscripts.html>. Acessado em: 13 jun. 2014.

SPINELLI, J.; PEDERSOLI JR., J. L. Biblioteca Nacional: plano de gerenciamento de riscos: salvaguarda e emergência. Rio de Janeiro: Fundação Biblioteca Nacional, 2010.

STJ DERRUBA decisão que condenou 4 por roubo ao Masp. Estadão, 20 out. 2009. Disponível em: <http://www.estadao.com.br/noticias/cidades,stj-derruba-decisaoque-condenou-4-por-roubo-ao-masp,453536,0.htm>. Acesso em: 03 fev. 2012.

STOLEN MUNCH paintings found safe. BBC News, 31 ago. 2006. Disponível em:<http://news.bbc.co.uk/2/hi/entertainment/5303200.stm>. Acesso em: 06 fev. 2012. 
TABLEAUX VOLÉS: un Français arrêté. Le Figaro, 28 ago. 2008. Disponível em: <http://www.lefigaro.fr/flash-actu/2008/06/28/01011-20080628FILWWW00461tableaux-voles-un-francais-arrete.php>. Acesso em: 03 fev. 2012.

TAVARES, B.; PEREIRA, R.; GODOY, M. A Polícia recupera obras roubadas do Masp em dezembro. Estadão, 08 jan. 2008. Disponível em: $<$ http://www.estadao.com.br/noticias/cidades,policia-recupera-obras-roubadas-domasp-em-dezembro,106155,0.htm>. Acesso em: 03 fev. 2012.

TELA DE DA VINCI roubada em 2003 é recuperada. Folha de São Paulo, 05 out. 2007. Disponível em: <http://www1.folha.uol.com.br/fsp/ilustrad/fq0510200739.htm>. Acesso em: 02 fev. 2012.

THEFT OF BOOKS AND MANUSCRIPTS FROM LIBRARIES: an advisory code of conduct for booksellers and librarians. Londres: CILIP, 2009. Disponível em: $<$ http://www.cilip.org.uk/get-involved/special-interest-groups/rare-

books/policy/Pages/policy_theft.aspx>. Acesso em: 16 abr. 2013.

TORTATO, M. Maioria das obras raras furtadas em Curitiba era de autores brasileiros. Folha de São Paulo, 09 nov. 2006. Disponível em: <http://www1.folha.uol.com.br/folha/cotidiano/ult95u128049.shtml>. Acesso em: 14 ago. 2010.

TRÊS QUADROS expressionistas são roubados de Museu de Gelsenkirchen. G1, 08 ago. 2008. Disponível em: <http://g1.globo.com/Noticias/PopArte/0,,mul7169337084,00-tres+quadros+expressionistas+sao+roubados+de+museu+de+gelsenkirc hen.html>. Acesso em: 03 fev. 2012.

TWO STOLEN Picassos found in Serbia. CBS News, 26 out. 2011. Disponível em: <http://www.cbsnews.com/8301-202_162-20126060/two-stolen-picassos-found-inserbia/>. Acesso em: 03 fev. 2012.

TWO VAN GOGH works are stolen in Amsterdam. The New York Times, 08 dez. 2002. Disponível em: <http://www.nytimes.com/2002/12/08/world/two-van-goghworks-are-stolen-in-amsterdam.html>. Acesso em: 06 fev. 2012.

UN TABLEAU de Degas, "les choristes", volé au musée Cantini de Marseille. Le Parisien, 31 dez. 2009. Disponível em: <http://www.leparisien.fr/flash-actualiteculture/un-tableau-de-degas-les-choristes-vole-au-musee-cantini-de-marseille-31-122009-761527.php>. Acesso em: 03 fev. 2012.

UNESCO. Convenção relativa às medidas a serem adotadas para proibir e impedir a importação, exportação e transferência de propriedades ilícitas dos bens culturais. Paris, novembro de $1970 . \quad$ Disponível em: <http://unesdoc.unesco.org/images/0016/001606/160638por.pdf>. Acesso em: 04 jun. 2013.

UNIVERSITÁRIO CONFESSA ter roubado escultura de Rodin. Estadão, 18 jun. 2005. em: <http://www.estadao.com.br/arquivo/arteelazer/2005/not20050618p5648.htm>. Acesso em: 06 fev. 2012. 
VALOTA, R. Polícia recupera 22 livros roubados do Instituto de Botânica. Estadão, 03 abr. 2012. Disponível em: <http://www.estadao.com.br/noticias/cidades,policiarecupera-22-livros-roubados-do-instituto-de-botanica,856903,0.htm>. Acesso em: 26 mar. 2003.

VIANNA, L. F. Livros dos séculos 17 e 19 são furtados do Museu Nacional, no Rio. Folha de São Paulo, 06 mai. 2004. Disponível em: <http://www1.folha.uol.com.br/folha/cotidiano/ult95u93898.shtml>. Acesso em: 14 ago. 2010.

VIAPIANA, L. T. Economia do crime. AGE: Porto Alegre, 2006.

WERSIG, G.; NEVELING, U. The phenomena of interest to information science. Information Scientist, v.9, n.4, p.127-140, 1975.

WHITTAKER, E. Albert Einstein: 1879-1875. Biographical memoirs of fellows of the royal society, 01 nov. $1955 . \quad$ Disponível em: <http://rsbm.royalsocietypublishing.org/content/1/3>. Acesso em: 15 fev. 2014. 